Universidade de São Paulo

Faculdade de Filosofia, Letras e Cî̂ncias Humanas

Departamento de Linguística

Programa de Pós-Graduação em Semiótica e Linguística Geral

\title{
Afasia e Linguagem Figurada: O Acesso Lexical Dentro de Contextos Metafóricos
}

\author{
Bruna Seixas Lima
}

Dissertação de mestrado apresentada ao Programa de Pós-Graduação em Semiótica e Linguística Geral do Departamento de Linguística da Faculdade de Filosofia, Letras e Ciências Humanas da Universidade de São Paulo.

Orientador: Prof. Dr. Marcos Lopes

São Paulo

dezembro de 2010 


\section{Agradecimentos}

Agradeço ao CNPq pela bolsa disponibilizada para esta pesquisa. Agradeço à minha família por sempre me incentivar a estudar (especialmente à Isabelle pelo apoio prático). Agradeço aos meus amigos e ao Cameron por estarem ao meu lado nas horas de crise. E agradeço ao Marcos por ser orientador, amigo e pai. 


\section{Resumo}

Esta pesquisa traz a análise de fenômenos linguísticos extraídos de entrevistas realizadas com seis sujeitos afásicos com diferentes graus de dificuldade de acesso lexical. Observamos a habilidade desses sujeitos em produzir e compreender nomes de animais utilizados em contexto não-literal.

Desenvolvemos uma entrevista para determinar se os sujeitos em questão apresentavam dificuldade para acessar os nomes de animais escolhidos. Numa primeira etapa, os sujeitos tiveram de nomeá-los e descrevê-los e, posteriormente, utilizá-los dentro de um contexto provido pela entrevistadora. A hipótese é que possa haver diferença entre a habilidade do sujeito para produzir e compreender nomes de animais dependendo do contexto apresentado.

Duas perspectivas de análise diferentes são apresentadas aqui: primeiro, temos as teorias baseadas em correlatos biológicos da linguagem e, em segundo, a teoria linguística de Roman Jakobson sobre o processamento da linguagem e a sua divisão em dois eixos principais, a metáfora e a metonímia (habilidades de abstração baseadas na similaridade e na contiguidade, respectivamente).

Alguns sujeitos apresentam dificuldade para produzir formas de palavras no seu sentido literal, mas o mesmo não acontece quando as mesmas palavras são produzidas no seu sentido não-literal, sugerindo que nesses sujeitos o sistema semântico-lexical pode estar mais preservado do que se imagina, sendo que o tipo de entrada ou saída dessas formas lexicais pode ser o elemento prejudicado. A análise das entrevistas realizadas revela que a compreensão dessas mesmas metáforas foi uma tarefa mais laboriosa para os sujeitos, o que reforça nossa hipótese, uma vez que durante a tarefa de compreensão das metáforas os sujeitos não foram providos do contexto dado na tarefa de produção. 


\section{Abstract}

This research proposes the analysis of language phenomena taken from interviews made with six aphasic subjects presenting different degrees of lexical access deficits. The focus of this paper is the observation of the ability of these subjects to produce and comprehend names of animals used in a metaphorical context.

We developed an interview in order to determine whether the subjects presented problems to access the chosen names of animals. In the first part of the interview, the subjects were asked to name and describe the animal pictures presented and, aftermost, they had to produce and comprehend those names in the context provided by the interviewer.

Two distinct perspectives are presented in this paper: first, we have theories based on biological correlates of language, and in second, the linguistic theory by Roman Jakobson about the processing of language and its division in two main axis: metaphor and metonymy (modes of relation based on similarity and contiguity, respectively).

Some subjects present distress to produce word forms in their literal meaning, whereas the same does not occur when those words are used in their nonliteral meaning. This suggests that these subjects present a better preservation of the semantic-lexical system than expected, and the only affected element can be the type of input or output of the lexical form. We can see in the interviews presented here that the comprehension of the mentioned metaphors was a more laborious task for the subjects, which reinforces our hypothesis, once during the comprehension part of the interview, the subjects were not provided with the context given previously, in the production task. 


\section{Sumário}

Agradecimentos

Resumo iii

Abstract iv

Lista de Figuras vii

Lista de Tabelas viii

1 Introdução 1

1.1 A afasia e a linguística ............... . . 1

1.2 A anomia e as categorias semânticas específicas ..... . . 3

1.3 A linguagem não-literal . . . . . . . . . . . . 5

1.3.1 Primeiro teste: dificuldade de acesso lexical e lingua-

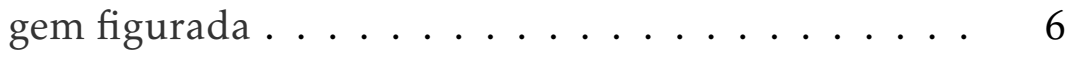

1.3 .2 Hipótese .................... 11

2 Os processos de formulação da linguagem no cérebro 13

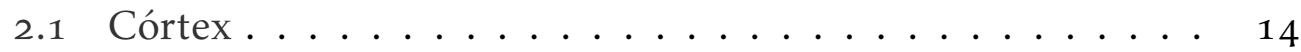

2.2 Redes funcionais . . . . . . . . . . . . . . . 15

2.3 Reuniões de células ou redes funcionais . . . . . . . 16

3 Redes de formas de palavras $\quad \mathbf{1 8}$

3.1 Redes de palavras de categorias específicas . . . . . . . 20

3.2 Palavras de ação e palavras relacionadas a imagens . . . . 20

3.3 Topografia das redes de palavras . . . . . . . . . 22 
4 Regulação e sobreposição $\quad 24$

4.1 Representações sobrepostas . . . . . . . . . . . . 24

4.2 Homófonos e palavras de forma fonológica relacionada . . 26

4 .3 Protótipos e semelhanças de família . . . . . . . . . . 27

4.4 Significado afetivo e emocional ............ 29

5 Entradas lexicais 31

5.1 A estrutura interna de uma entrada lexical . . . . . . . 31

5.2 Relações entre itens no léxico mental . . . . . . . . . . 32

$5 \cdot 3$ Espalhamento da ativação . . . . . . . . . . 34

6 Acesso Lexical e Falhas de Acesso Lexical 37

6.1 Falhas de acesso lexical ............... 39

6.1.1 Tipos de falhas de acesso lexical ........ 40

7 Afasias $\quad 45$

7.1 Alterações da habilidade de nomeação . . . . . . . . . 48

8 A afasia sob um ponto de vista linguístico 51

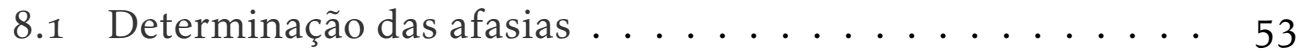

8.2 Primeira dicotomia .................... 54

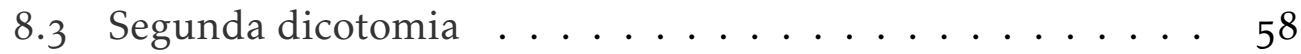

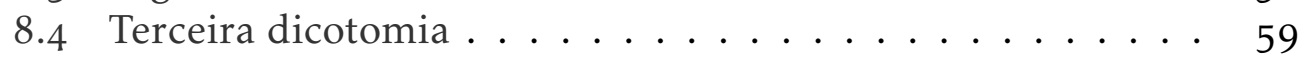

8.5 Conclusão ....................... 6o

9 As entrevistas $\quad 63$

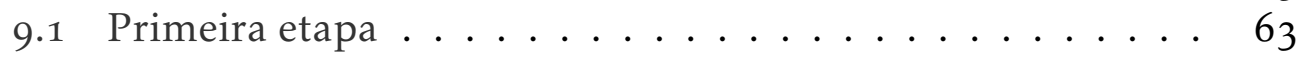

9.2 Segunda etapa . . . . . . . . . . . . . . 64

9.3 Terceira etapa ................... 65

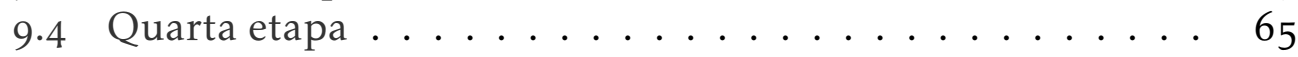

10 Apresentação dos sujeitos e análise dos dados 68

10.1 Os sujeitos . . . . . . . . . . . . . . 68 68

10.1.1 Sujeito: AA . . . . . . . . . . . . . . 68

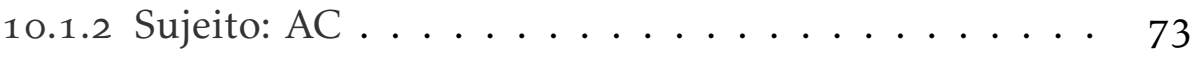

10.1 .3 Sujeito: CP ............... . . . 79

10.1.4 Sujeito: DP . . . . . . . . . . 85

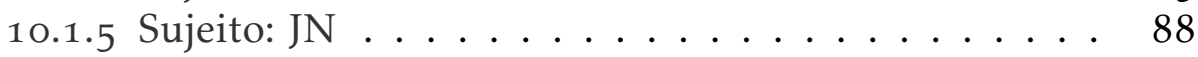

10.1 .6 Sujeito: SR ................... 93 
11 As metáforas $\quad 98$

$11.1 \mathrm{O}$ contexto como facilitador do acesso lexical . . . . . . . . . 99

11.2 Metáforas: produção e compreensão . . . . . . . . . . 101

11.2.1 Sujeito CP . . . . . . . . . . . . 101

11.2 .2 Sujeito AA . . . . . . . . . . 105

11.2 .3 Sujeito AC . . . . . . . . . . . 109

11.2 .4 Sujeito DP . . . . . . . . . . . . 117

11.2 .5 Sujeito SR . . . . . . . . . . 120

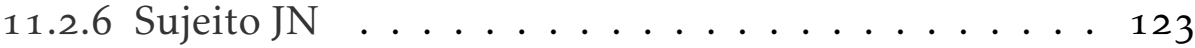

12 Discussão dos resultados $\quad 127$

12.1 Produção de nomes em linguagem literal × não-literal . . . 129

12.2 Análise linguística . . . . . . . . . . . . . . . . . 134

12.3 Produção e compreensão . . . . . . . . . . . . . 135

$\begin{array}{lr}13 \text { Conclusão } & 138\end{array}$

$\begin{array}{lr}\text { Referências } & 141\end{array}$

$\begin{array}{lr}\text { Anexos } & 149\end{array}$

$\begin{array}{lr}\text { Transcrição das entrevistas } & 160\end{array}$

13.1 Sujeito: AA . . . . . . . . . . . . . 160

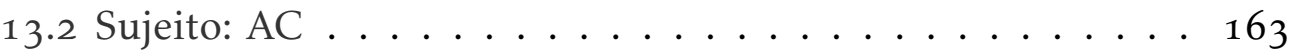

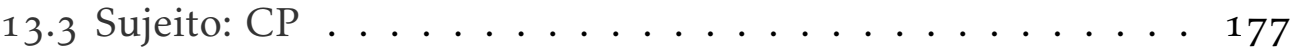

13.4 Sujeito: DP . . . . . . . . . . . . . . 183

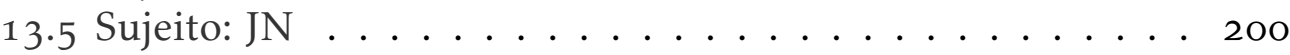

13.6 Sujeito: SR . . . . . . . . . . . . . 216

13.7 Segunda Parte . . . . . . . . . . . . 226

13.8 Sujeito: AA . . . . . . . . . . . . . . 226

13.9 Sujeito: AC . . . . . . . . . . . . . . . 236

13.10Sujeito: CP ..................... 254

13.11Sujeito: DP . . . . . . . . . . . . 266

13.12Sujeito: JN . . . . . . . . . . . . . . . . . 275

13.13Sujeito: SR . . . . . . . . . . . . . 294 


\section{Lista de Figuras}

12.1 Os níveis de acesso lexical. Adaptado de (Jescheniak \& Levelt, 1994); (Roelofs et al., 1996) . . . . . . . . . . . . 131

13.1 Um burro . . . . . . . . . . . . . . . . 150

13.2 Uma cobra .......................... 151

13.3 Um elefante . . . . . . . . . . . . 152

$13.4 \mathrm{Um}$ gato . . . . . . . . . . . . . . . . . 153

13.5 Uma girafa . . . . . . . . . . . . . . . . . 154

13.6 Um touro . . . . . . . . . . . . . . 155

13.7 Um porco . . . . . . . . . . . . . . . 156

13.8 Uma tartaruga . . . . . . . . . . . . . . . 157

13.9 Uma baleia . . . . . . . . . . . . . . . . 158

$13.10 \mathrm{Um}$ cavalo . . . . . . . . . . . . . . . . 159

viii 


\section{Lista de Tabelas}

1.1 Sujeito ES: Teste de compreensão de metáforas . . . . . . . 9

1.2 Sujeito ES: Teste de descrição de animais . . . . . . . . 10

1.3 Sujeito ES: Teste de produção de metáforas . . . . . . . . . 11

11.1 Definição de metáforas do sujeito CP. O sujeito teve de observar as figuras enquanto respondia . . . . . . 106

11.2 Definição de metáforas do sujeito AA (com ajuda) . . . . . 108

11.3 Definição de metáforas do sujeito AC (com ajuda) . . . . . . 118

11.4 Definição de metáforas do sujeito DP . . . . . . . . . 120

11.5 Produção de metáforas do sujeito SR . . . . . . . . . 122

11.6 Definição de metáforas do sujeito SR . . . . . . . . . 122

11.7 Produção de metáforas do sujeito JN . . . . . . . . . . 125

11.8 Definição de metáforas do sujeito JN . . . . . . . . . 126

12.1 Resultado do teste de produção de nomes literais e metáforas: número de acertos por paciente . . . . . . . . 128 


\section{Capítulo 1}

\section{Introdução}

\subsection{A afasia e a linguística}

Este trabalho trata da observação dos déficits de linguagem de sujeitos afásicos com diferentes graus de dificuldade para a nomeação de objetos. Esses sujeitos foram entrevistados nas dependências do CCA (Centro de Convivência de Afásicos) do Instituto de Estudos da Linguagem da Universidade Estadual de Campinas em maio de 2010. Mais especificamente, seis sujeitos foram entrevistados para a realização desta pesquisa na tentativa de analisar seus respectivos déficts de linguagem, a dificuldade de acesso lexical, e - o que será o ponto chave dessa dissertação — suas habilidades para produzir e compreender metáforas.

Os sujeitos selecionados apresentam diferentes tipos de lesão e diferentes tipos de prejuízos linguísticos. A caracterização dos padrões de afasia pode ser descrita, grosso modo, como a dificuldade de performance em algumas tarefas específicas da linguagem. Alguns pacientes se tornam incapazes de falar sem grande esforço, mas permanecem capazes de compreender, enquanto outros, apesar de falarem fluentemente, desenvolvem dificuldades de compreensão do que lhes é dito. Esses padrões foram nomeados como afasia expressiva e afasia receptiva, também conhecidas como afasia de Broca e afasia de Wernicke. Obviamente essa definição é bastante simplificada, na realidade, existem diversos fenômenos que podem ser encontrados nas afasias e em toda afasia, com exceção de alguns casos específicos, existe um grau mais ou menos importante de anomia, (a dificuldade para nomear objetos) existindo em cada forma um traço clínico 
A afasia e a linguística

característico (Peña-Casanova, 2005).

As teorias anátomo-clínicas mais recentes mantêm a distinção entre os dois tipos de sujeitos afásicos e suas respectivas áreas danificadas no cérebro (apesar de as definições "afásico de Broca" e "afásico de Wernicke" não estarem necessariamente ligadas às áreas corticais conhecidas como área de Broca e área de Wernicke, mas sim aos sintomas dessas afasias). No entanto, as pesquisas nessa área agora levam em consideração questões relacionadas à linguística e à psicolinguística a fim de analisar os déficits observáveis nas síndromes afásicas em componentes discretos do sistema da linguagem.

As unidades de função da linguagem localizáveis são tomadas como elementos estruturais abstratos e mecanismos de processamento que compõem o sistema normal. Uma ideia central para a descrição dos déficits linguísticos levando em consideração tais questões é a hipótese de que diferentes déficits de linguagem podem ocorrer por várias razões em cada paciente. Essa descoberta não é nova (por exemplo, Luria, 1947/1970), mas apenas recentemente os mecanismos que são reconhecidos como responsáveis por esses déficits têm sido articulados em termos de um vocabulário teórico desenvolvido (Berndt et al., 1983).

Ainda segundo os mesmos autores, o progresso das pesquisas sobre afasia depende, portanto, em grande parte da disponibilidade de modelos bem desenvolvidos de funcionamento. Quando um modelo razoavelmente preciso está disponível, pode-se promover tentativas de caracterizar mais ou menos precisamente a estrutura dos prejuízos causados pela afasia tanto em sujeitos, individualmente, como dentro das síndromes específicas.

Pulvermüller (2002) afirma que ideias sobre como conectar o nível de descrição da linguagem com o nível de descrição dos neurônios, ou seja, a correlação anátomo-clínica com a descrição do funcionamento linguístico, são necesssárias. Os esforços teóricos podem levar à geração de previsões que podem ser trabalhadas em experimentos.

É possível que problemas entre os termos linguísticos e os termos médicos sejam resolvidos e possamos desenvolver uma linguagem que seja referente às estruturas linguísticas e às estruturas cerebrais, aos processos linguísticos e aos processos cerebrais. Se tal linguagem estivesse disponível seria possível explorar os campos restritos de ambas as áreas. $\mathrm{O}$ uso de informação neurocientífica poderia ajudar as teorias linguísticas e vice-versa. O estudo da linguagem pode permitir a previsão de circuitos cerebrais que não tenham ainda sido descobertos por outros meios, afinal, os ins- 
A anomia e as categorias semânticas específicas

trumentos que monitoram a atividade cerebral não dizem ao pesquisador pelo que procurar quando estiver observando representações e processos linguísticos.

Os padrões de atividade cerebral que possivelmente indiquem aspectos do processamento linguístico foram descobertos apenas devido a previsões bem embasadas sobre a base cerebral desse processamento. Sem as teorias nas quais essas previsões foram embasadas, a probabilidade de decoberta desses padrões seria nula.

A construção de uma teoria que abranja os mecanismos orgânicos de linguagem e a linguística não é uma tarefa fácil, e não é esperado que um trabalho dessa dimensão leve a resultados imediatos para as perguntas feitas sobre a linguagem. No entanto, é importante que neste estágio de desenvolvimento desses estudos mais pesquisas teóricas a respeito do cérebro e da linguagem sejam realizadas, e para tanto, os linguistas também precisam de um modelo cerebral dos processos linguísticos.

\subsection{A anomia e as categorias semânticas especí- ficas}

No que diz respeito à anomia, que como mencionamos é a dificuldade para nomear objetos, muitos afásicos apresentam prejuízos ligados a categorias semânticas específicas. Isso significa que o déficit linguístico desses sujeitos pode seguir um padrão cujas propriedades são discutidas por diferentes teorias (tais quais a oposição entre traços semânticos como animado ou inanimado, ou suas propriedades sensoriais em oposição às funcionais) (Damasio et al., 1996). Ou seja, alguns sujeitos que sofrem de anomia podem ter prejuízos ligados a categorias semânticas específicas, como seres vivos, ou ferramentas. Na produção do discurso de um sujeito com esses déficits linguísticos pode-se encontrar alterações que identifiquem categorias específicas nas quais ele apresente maior dificuldade. Martin \& Caramazza (2003) oferecem uma breve apresentação dos estudos do mapeamento das atividades no cérebro. Dentre as descobertas, os autores citam aquela de regiões do cérebro mais comumente associadas com a representação de categorias de objetos. As atividades dessas regiões são moduladas por categorias: objetos pertencentes a categorias semânticas diferentes produzem padrões diferentes de atividade. No entanto, ainda há 
muito a se determinar sobre o processamento de características, ou tipo de informação, representadas nestas regiões.

Esse fenômeno gera uma base empírica para teorias direcionadas à organização do conhecimento conceitual no cérebro (Capitani, 2003). Essas teorias são divididas em dois tipos:

- princípio da estrutura correlacionada: as teorias que seguem esse princípio acreditam que a organização do conhecimento conceitual no cérebro é um reflexo da co-ocorrência estatística das propriedades dos objetos. De acordo com essas teorias, se um dano cerebral pode afetar seletivamente certas áreas do espaço conceitual, quer seja porque esses centros são próximos um do outro no cérebro, ou porque os danos causados a uma certa propriedade vão se propagar para outras propriedades altamente correlacionadas, então é possível que categorias específicas de objetos sejam prejudicadas (relativamente) independentemente umas das outras.

- princípio da estrutura neural: essas teorias acreditam que a organização do conhecimento conceitual é governada por restrições impostas pelo próprio cérebro. Dentro dessa teoria existem mais dois sub grupos de pesquisas. O primeiro grupo acredita que o conhecimento conceitual é distribuído entre subsistemas semânticos de modalidade específica que são funcionalmente e neuroanatomicamente distintos. O segundo grupo acredita que a dimensão para a organização do conhecimento conceitual no cérebro é determinada pelo papel que esses objetos representaram na nossa história evolutiva. Especificamente, acredita-se que as pressões causadas pela seleção natural resultaram em circuitos neurais de domínio específico, dedicados a resolver, rapidamente e eficientemente, problemas complexos de sobrevivência (como evitar predadores e encontrar comida).

Ainda segundo o mesmo autor, mais ou menos três quartos dos casos apresentados na literatura de déficits de categorias específicas apresentam maior dificuldade para nomear seres vivos, e um quarto apresenta o padrão contrário.

Nos afásicos, em geral, observa-se maior dificuldade no emprego de palavras abstratas quando comparadas com palavras concretas (Mansur, 2004). Isso pode acontecer pelo fato de que palavras concretas apresentam 
A linguagem não-literal

um código duplo, verbal e não-verbal (a imagem), ao contrário das palavras abstratas que apresentam apenas o código verbal. Além disso, palavras concretas apresentam um maior número de características semânticas e estão inseridas num contexto perceptual maior, uma vez que estas apresentam um maior número de atributos sensório-motores que facilitariam a sua retomada.

Isso nos leva a considerar como se dá a produção e compreensão de figuras de linguagem, já que a linguagem não-literal (apesar de ser abstrata) necessita de elementos que utilizam traços semânticos da linguagem literal. Assim sendo, estabelecemos como ponto principal dessa pesquisa a questão sobre como (e se) sujeitos com dificuldade de acesso lexical conseguiriam utilizar determinados itens lexicais em seu discurso em diferentes situações de contexto, ou seja: se uma palavra não consegue ser pronunciada ou entendida numa situação em que o seu significado literal seja necessário, o que aconteceria se essa mesma palavra fosse evocada em situação nãoliteral?

\subsection{A linguagem não-literal}

A metáfora e a metonímia são figuras de linguagem consideradas pela retórica tradicional como figuras de palavras, introduzidas num discurso de modo a criar caminhos diferentes para a compreensão de um enunciado. Elas são a adição de um significado a outro, quando há entre esses dois significados uma relação de semelhança ou intersecção, ou seja, para que se faça uso de uma metáfora, é preciso que haja um significado comum entre os dois termos que utilizarmos (Fiorin, s/ data).

As figuras de linguagem são parte recorrente do nosso discurso. São inúmeros os exemplos que podemos listar de frases feitas utilizando esse recurso. Algumas são conhecidas e disseminadas por todos, ou pela maioria dos falantes de uma determinada língua, e outras novas metáforas são criadas todos os dias.

Lakoff \& Johnson (1980) afirmam que o uso da linguagem figurada ocorre quando existe a necessidade de se explicar uma coisa em termos de outra coisa, ou seja, nós aproximamos dois termos com alguma semelhança entre si de forma que o caminho para a compreensão de um enunciado passa a ter uma segunda via facilitadora para o acesso a um ponto final. Os conceitos seriam estruturados por metáforas, e nós agiríamos de acordo 
com o modo como concebemos as coisas.

Muitas teorias tentam explicar como o cérebro compreende a linguagem metafórica (Blasko (1993); Swinney \& Cutler (1979); Cacciari (1988)). Existem suposições sobre a ligação do objeto figurado ao não-figurado e às suas características semânticas, bem como estudos de observação de ativação cerebral (Papagno, 2001).

Em um trabalho realizado anteriormente (publicação em fase de elaboração), observamos um sujeito afásico cujos prejuízos linguísticos levantaram questões sobre a anomia e a metáfora. A pesquisa propôs um estudo de caso de um indivíduo incapaz de nomear grande parte dos objetos presentes em sua vida cotidiana, sofrendo de anomalias semânticas apresentadas na fala em virtude de uma queda em sua residência por conta da qual sofreu traumatismo crânio-encefálico (TCE). O neurologista que o atendeu sugeriu o diagnóstico de Síndrome do Giro Angular (alexia e agrafia, ou seja perda das capacidades de ler e escrever), consequências do TCE, que gerou danos nos lobos frontal esquerdo e parietal direito, hematoma sub-dural agudo e hemorragia meníngea traumática.

Desde então, o sujeito passou a apresentar falhas na compreensão e produção da linguagem caracterizadas pela falta de habilidade de evocar palavras, além de sérios problemas na leitura e na escrita. Passou por diversos testes de nomeação, como o Boston Naming, nos quais foram observadas dificuldades para produzir nomes em geral. Com a aplicação de testes linguísticos, foi determinado que o paciente apresentava maior dificuldade de produção quando se tratava de categorias semânticas específicas, como nomes de animais.

A partir dessa informação, resolvemos verificar como a produção e compreensão de nomes de animais aconteceria quando estes fossem colocados em um contexto metafórico. O sujeito passou por testes de metáforas elaborados para esta pesquisa, e por um teste de ditados populares (Siviero, 1997) para verificar a sua compreensão do sentido não-literal em geral.

Os testes e os seus resultados estão explicados resumidamente a seguir.

\subsubsection{Primeiro teste: dificuldade de acesso lexical e lingua- gem figurada}

Foram selecionados quinze nomes de animais que pudessem ser utilizados em linguagem figurada no português. São eles: 
- Anta

- Elefante

- Baleia

- Cavalo

- Perua

- Gato

- Touro

- Girafa

- Cobra

- Burro

- Lesma

- Porco

- Sanguessuga

- Tartaruga

- Cachorro

Uma das características da linguagem metafórica é o destaque de um único termo relacionado ao que se quer nomear, em oposição ao rebaixamento de todos os outros (Lakoff \& Johnson, 1980), ou seja, um animal como o porco possui diversas características, porém quando a palavra porco é aplicada dentro de um enunciado não-literal, apenas uma dessas características é evocada: "sujo", ou "sem higiene", "sem modos". Portanto, para que o paciente pudesse responder qual era o significado correto de cada um dos nomes citados acima, apresentamos a ele três opções de adjetivos para cada nome, sendo uma delas a de significado mais aproximado à metáfora em questão, e as demais, outros adjetivos não relacionados à mesma. Os dois termos não relacionados ao nome do animal foram escolhidos aleatoriamente e tomamos o cuidado de utilizar palavras com similar valor moral. 
O que queremos dizer é que se o nome "porco", ao ser aplicado a uma pessoa, é geralmente assimilado como uma qualidade negativa, então as três opções apresentadas ao paciente compartilhavam esse traço valorativo, como no exemplo:

Porco

- covarde

- pobre

- sujo

O objetivo do teste era verificar se o paciente conseguiria ou não identificar qual adjetivo mais se aproximava do significado do nome do animal em questão quando utilizado num contexto metafórico. Se o sujeito conseguisse identificar características dos animais em questão, isso nos diria se ele é capaz de recuperar traços semânticos o suficiente para compreender aquelas metáforas. Os nomes e as alternativas foram lidos para o paciente, pedindo sempre que considerasse um contexto não-literal (por exemplo: "O João é porco").

Sabendo que o paciente tem dificuldade em se lembrar de nomes de animais, poderíamos esperar que durante esse teste tal dificuldade também se apresentaria, no entanto, o paciente foi capaz de acertar treze das quinze questões apresentadas, como vemos na tabela 1.1.

A partir desse resultado aplicamos um segundo teste. Por questões de praticidade, a lista de quinze animais foi reduzida a onze (os nomes perua, sanguessuga, lesma e anta foram excluídos pois não seriam adequados para o teste seguinte) e elaboramos uma lista de características comumente evocáveis quando descrevemos os animais apresentados anteriormente, desta vez em situação literal. Uma vez que no teste anterior o paciente se mostrou capaz de recuperar os traços semânticos dos nomes em questão dentro de um contexto não-literal, este segundo teste foi aplicado com o objetivo de verificar se o sujeito conseguiria desta vez descrever os animais apresentados em situação literal. Os nomes dos animais foram novamente apresentados ao paciente e pedimos que ele elencasse quais características 


\begin{tabular}{ll}
\hline Animal & Resposta do paciente \\
\hline Anta & muito bobo \\
Elefante & gordo \\
Baleia & gordo \\
Cavalo & grosseiro \\
Perua & gorda \\
Gato & bonito \\
Touro & forte \\
Girafa & alta \\
Cobra & maldosa \\
Burro & pouco inteligente \\
Lesma & lenta \\
Porco & sujo \\
Sanguessuga & aproveitador \\
Tartaruga & come muito \\
Cachorro & cafageste \\
\hline
\end{tabular}

Tabela 1.1: Sujeito ES: Teste de compreensão de metáforas 


\begin{tabular}{ll}
\hline Animal & Resposta do paciente \\
\hline Elefante & muito grande, muito gordo, anda devagar \\
Baleia & nadadora, eu acho bonita, muito calma \\
Cavalo & $\begin{array}{l}\text { animal grande e forte } \\
\text { Gato }\end{array}$ \\
animal caseiro \\
Touro & animal grande, consegue puxar coisas pesadas \\
Girafa & alta, cabelo vai no alto \\
Cobra & se arrasta, pode matar \\
Burro & é um animal parecido com o cavalo, mas a orelha é maior \\
Porco & sujo \\
Tartaruga & voa e suja tudo \\
Cachorro & animal de casa, não gosta do outro animal de casa \\
\hline
\end{tabular}

Tabela 1.2: Sujeito ES: Teste de descrição de animais

lhe eram familiares ao pensar nestes animais. As características foram listadas sem grande dificuldade. Obtivemos os resultados apresentados na tabela 1.2.

Levando em consideração os testes anteriores, podemos supor que o paciente não apresenta dificuldades no que diz respeito ao conceito dos nomes apresentados. Tanto dentro de contextos literais como não-literais, ele foi capaz de descrever os animais ou metáforas em questão. O intuito deste terceiro teste foi, portanto, verificar se o sujeito conseguiria produzir os nomes de animais, ao invés de descrevê-los. Diferente do teste anterior, desta vez foi o examinador quem ditou algumas características típicas dos animais e coube ao paciente nomear os animais sendo descritos, ou seja, o sujeito ouviu descrições como: Este animal é rápido, participa de corridas, salta, tem casco, tem crina, tem quatro patas.

Além de apresentar esses traços semânticos, figuras dos mesmos animais foram simultaneamente apresentadas ao paciente, dos quais ele lembrou apenas três dos onze nomes apresentados (elefante, girafa e porco) do que podemos observar que o processo de nomeação se difere do processo de descrição, uma vez que no teste anterior, no qual o nome já havia sido dado, o paciente apresentou resultados satisfatórios.

No quarto e último teste encontramos uma diferença na produção de nomes em contexto metafórico ou não metafórico no discurso do paciente. 


\begin{tabular}{ll}
\hline Resposta esperada & Resposta do paciente \\
\hline Elefante & - \\
Baleia & Baleia \\
Cavalo & Cavalo \\
Gato & - \\
Touro & Touro \\
Girafa & Girafa \\
Cobra & Cobra \\
Burro & Burro \\
Porco & Porco \\
Tartaruga & - \\
Cachorro & Cachorro \\
\hline
\end{tabular}

Tabela 1.3: Sujeito ES: Teste de produção de metáforas

Os animais apresentados nas figuras foram colocados em contextos nãoliterais e ao paciente foi pedido que dissesse que nome de animal seria mais adequado naquelas situações. Por exemplo:

Um homem que não gosta de tomar banho, não lava as mãos, come de boca aberta, do que é chamado? Resposta: Porco.

O paciente obteve sucesso em oito das onze situações:

\subsubsection{Hipótese}

Baseando-nos nos resultados obtidos com essa pesquisa, acreditamos que possa haver diferença entre a habilidade do sujeito para produzir e compreender nomes de animais dependendo do contexto que lhe for apresentado, literal ou não-literal. Portanto, esta pesquisa tem como propósito verificar em outros sujeitos com dificuldade de acesso lexical se o emprego de contextos conversacionais focados na relevância pragmática (como é o caso das metáforas) afetaria o acesso lexical dos demais contextos para esses pacientes com déficits semânticos de categorias específicas.

Observando os resultados dos testes, percebemos que o paciente anômico, mesmo diante da categoria específica na qual apresenta maior dificuldade, apresentou maior habilidade para produzir estes nomes quando colocados em linguagem figurada (na tarefa de nomeação das figuras em si- 
tuação literal, o sujeito conseguiu nomear apenas três animais, enquanto na tarefa de produção das metáforas, nomeou oito deles), ou seja, a linguagem figurada aliviou essa dificuldade significativamente.

Segundo Peña-Casanova (2005), em casos como o do sujeito citado, no qual o léxico de um indivíduo está afetado, se o problema estiver centrado na degradação do conhecimento semântico, ou seja, nas representações semânticas em si, serão necessárias técnicas compensatórias para suprimir os itens lexicais perdidos, por outro lado se o problema estiver no acesso semântico, será preciso que se encontrem estratégias que permitam o menor tempo de processamento para que se chegue ao objetivo. Presumivelmente, as metáforas, por conta do seu atrelamento pragmático na experiência social do paciente, podem facilitar o acesso lexical.

Portanto, nesta pesquisa faremos uma análise sobre o conteúdo de entrevistas gravadas em áudio com os seis sujeitos afásicos mencionados acima, a fim de observarmos se o uso da linguagem não-literal pode facilitar ou prejudicar o acesso aos itens lexicais. Os capítulos a seguir apresentarão duas perspectivas de análise diferentes: primeiro veremos as bases biológicas da linguagem e respectivas teorias que podem explicar como uma mesma palavra pode ser acessada por vias diferentes no que diz respeito aos mecanismos cerebrais, e em seguida, veremos uma explicação baseada na teoria linguística de Jakobson sobre as afasias. 


\section{Capítulo 2}

\section{Os processos de formulação da linguagem no cérebro}

A fim de nos aprofundarmos nas questões sobre a conexão entre a linguagem e as suas bases biológicas, alguns esclarecimentos devem ser feitos sobre as principais áreas da linguagem no cérebro. Começaremos mencionando as áreas mais conhecidas como essenciais para a linguagem para depois detalharmos as áreas mais importantes para a cognição e o acesso lexical.

As áreas de Broca e Wernicke são áreas comumente relacionadas à linguagem, localizadas no hemisfério esquerdo do córtex cerebral. Há mais de um século essas áreas e suas interligações são a base para o raciocínio sobre fisiopatologia em estudos de afasia (Mansur, 2004). Sabe-se hoje em dia que as síndromes descritas pelos dois neurologistas que nomearam essas áreas não se encaixam perfeitamente nos casos clínicos observados atualmente ( $15 \%$ dos afásicos de Broca não apresentam lesão na área correspondente, $o$ mesmo acontece com 35\% dos afásicos de Wernicke). Ainda assim, ambas as áreas apresentam projeções ligadas à linguagem.

Do ponto de vista neurológico, a fissura Silviana (localizada entre os lobos frontal e temporal), é um marco importante da anatomia cerebral quando falamos de linguagem, pois todas as áreas mais relevantes para a linguagem estão localizadas nas áreas próximas a ela, são as chamadas áreas perisilvianas.

Apesar de as áreas de Broca e Wernicke terem sido por algum tempo reconhecidas como as únicas áreas cruciais para a linguagem, trabalhos neuropsicológicos realizados no último quarto do século XX provaram que 
outras áreas são necessárias para o perfeito processamento da linguagem. Em particular, lesões nos lobos frontal e temporal, que algumas vezes poupam as áreas perisilvianas da linguagem, levaram à dificuldade na produção e compreensão de palavras. Muitos desses déficits são mais pronunciados com palavras de categorias particulares - nomes, verbos, ou subcategorias semânticas mais detalhadas de palavras e conceitos (Damasio \& Tranel (1993); Humphreys \& Forde (2001); Warrington \& McCarthy (1983) e Warrington \& Shallice (1984)).

Um modelo da linguagem deve especificar os mecanismos nos quais o uso e a compreensão da língua se baseiam. Portanto, devemos especificar as bases conhecidas para o uso e a compreensão da língua no que diz respeito aos neurônios, às conexões neuronais e aos circuitos neuronais. Isso não quer dizer que necessariamente esse modelo deva especificar cada um dos neurônios participantes, mas sim que os circuitos que têm a reputação de serem responsáveis por grande parte da função da linguagem devem ser especificados tanto quanto for possível e relevante.

\subsection{Córtex}

A parte cerebral mais relevante para a linguagem é o córtex, que é a camada mais externa do cérebro. Esse fato foi provado por observações neurológicas - em particular, pelo fato de que lesões em determinadas áreas do córtex levam a problemas neurológicos relacionados à linguagem. Estudos recentes com neuroimagens também confirmam essa afirmação (Pulvermüller, 2002).

Cada hemisfério pode ser subdividido em áreas menores. Essa divisão varia entre cinquenta e cem áreas. No entanto, uma divisão mais simplificada pode ser feita se levarmos em consideração os lobos. Os lobos são divididos em lobo frontal, lobo parietal, lobo occipital e lobo temporal. Existem dois pontos que marcam as fronteiras entre os lobos: o sulco central e a fissura silviana.

As principais áreas para o processamento da linguagem são as seguintes:

- Lobo occipital posterior onde as fibras do caminho visual alcançam o córtex (córtex visual primário)

- Lobo temporal superior onde as fibras do caminho auditivo alcançam o córtex (córtex auditivo primário) 
Redes funcionais

- Giro pós-central do lobo parietal onde os inputs somato-sensórios alcançam o córtex (córtex somato-sensório primário)

- Giro pré-central do lobo frontal cujos neurônios eferentes entram em contato com os neurônios motores e controlam as contrações musculares (córtex motor primário)

Existem projeções topográficas ordenadas entre os músculos do corpo e os pontos do córtex motor primário, e projeções desse tipo existem nos sistemas visual, auditivo e somato-sensório também. Essas projeções são estabelecidas muito cedo. Elas podem, no entanto, ser alteradas, por exemplo, como consequência de danos causados ao cérebro. Pesquisas em reorganização cortical mostraram que as representações corticais podem mudar dramaticamente (Buonomano \& Merzenich (1998); Kujala et al. (2000); Kaas et al. (1983)). Uma mudança nas áreas corticais pode acontecer até mesmo devido a processos de aprendizagem. Músicos e leitores de braille, por exemplo, apresentam uma função alterada das áreas somato-sensórias, com representações corticais ampliadas das extremidades envolvidas em habilidades sensório-motoras mais complexas (Elbert et al. (1995) Sterr et al. (1998)). Isso mostra que as projeções topográficas não são fixadas geneticamente. Elas podem variar dentro de certos limites.

\subsection{Redes funcionais}

O córtex é composto por uma rede de neurônios caracterizada por conexões ordenadas em áreas de modalidade específica, por trocas de informações entre conexões de curta e de longa distância e pelo aprendizado de correlação (o pricípio de aprendizado de correlação afirma que padrões de atividade neuronal que co-ocorram com frequência podem ser armazenados de modo a fortalecer as ligações sinápticas entre os neurônios participantes dessas atividades), de acordo com Pulvermüller (2002). Esses mecanismos podem conectar neurônios que respondem a características específicas de padrões de entrada de informação e neurônios que controlem aspectos motores de saída da informação.

Como as diferentes áreas primárias (as áreas que são responsáveis pelos movimentos musculares e pela sensibilidade, por exemplo) não são conectadas diretamente, neurônios que estejam localizados em outras áreas podem ser mobilizados para ordenar os padrões de entrada e saída. A 
Reuniões de células ou redes funcionais

estrutura de conexão cortical, caracterizada por uma alta probabilidade de conexão entre áreas adjacentes e outras ligações de longa distância, permite a formação de redes conectadas, porém distribuídas, de neurônios que alcançam as áreas primárias. Essas redes são chamadas de redes funcionais.

Hebb (2002) afirma que a ativação sincrônica de neurônios levaria a uma reunião de células e essas reuniões seriam a base de todos os principais processos cognitivos.

Damasio (1991) sugeriu que as categorias de conhecimento são processadas por zonas de convergência e não por neurônios solitários. O padrão de conexão neuroanatômico do córtex indica que ligações entre córtices primários acontecem por vários caminhos que envolvem diversas áreas não primárias. Portanto, não se pode afirmar que apenas uma área seja especializada para a localização de uma entidade específica. Isso quer dizer que uma rede distribuída de neurônios que processam um certo tipo de informação pode incluir um grande número de células especializadas distribuídas em muitas áreas corticais.

\subsection{Reuniões de células ou redes funcionais}

As reuniões de células mencionadas anteriormente são um conceito bastante subjetivo. Isso porque é difícil determinar quais neurônios especificamente fazem parte de uma reunião e quais não fazem. Em estímulos usando memórias associativas artificiais (Sommer \& Palm, 1999), pode-se encontrar imediatamente os problemas para definir quais neurônios estão agrupados (formando portanto uma rede funcional) dentro de uma rede neuronal. O que podemos encontrar são neurônios que são conectados uns aos outros por uma grande força de sinapse, e isso demonstra claramente que eles são membros de uma reunião de células. No entanto, existem outros neurônios cujas conexões com outros membros da rede são apenas ligeiramente mais fracas, e portanto, a sua inclusão é incerta.

É importante sabermos que essa subjetividade não chega a constituir um problema principal. Segundo Pulvermüller (2002) esse problema se assemelha à dificuldade de determinarmos as fronteiras do sol ou da via láctea. Apesar dos limites físicos serem difíceis de esclarecer, essas redes são unidades discretas no que diz repeito à sua funcionalidade.

Uma rede de ligações neuronais que conecta fortemente todos os neurônios envolvidos nos processos específicos ativados por um input pode se 
Reuniões de células ou redes funcionais

tornar a representação cortical desse objeto. Nesse caso, as características desse objeto seriam estabelecidas por ligações mútuas dentro de uma rede funcional distribuida, ou seja, uma ligação feita entre um conjunto de neurônios em áreas espalhadas do córtex. Cada neurônio ativado seria um membro dessa reunião e contribuiria para a união da rede, tornando-se essencial para o seu funcionamento. O conceito de GATO, por exemplo, seria realizado através de um grande grupo de neurônios distribuídos em um pequeno grupo de áreas corticais. Uma rede funcional, portanto, é constituída por neurônios que:

- São fortemente conectados uns aos outros

- São distribuídos em um conjunto específico de áreas corticais

- Trabalham juntos como uma unidade funcional

- São funcionalmente dependentes, na maioria das suas partes, tanto que cada um seja necessário para o funcionamento perfeito da rede

Se os neurônios de uma rede funcional são necessários para o processamento perfeito de uma entidade, uma lesão em uma porção significante da rede de neurônios deve prejudicar o processamento dessa entidade, independentemente de onde essa lesão ocorrer.

Por outro lado, se uma rede de neurônios é considerada como a representação de memória de um objeto, e cada neurônio representar uma característica em particular desse objeto, a ignição completa seria a ativação da representação armazenada do objeto. Mas essa ativação poderia ocorrer mesmo que apenas uma fração das características do objeto esteja presente no input.

O fato de que uma ativação pode ser completada organicamente através de poucas características de uma entidade pode ser um processo importante. Se pensarmos que, de fato, isso seja possível, a ativação de algumas características semânticas de um objeto podem levar à completa ativação desse objeto, desse modo os sujeitos que apresentam problemas de acesso lexical podem encontrar diferentes caminhos para alcançar uma palavra, ou um conceito até então perdidos. 


\section{Capítulo 3}

\section{Redes de formas de palavras}

Existe uma correlação interessante entre a aquisição da linguagem e a perda da mesma citada por Jakobson (2003). Aparentemente, a desintegração do sistema fônico apresenta uma ordem temporal de grande regularidade, a regressão afásica se revelou um espelho da aquisição de sons da fala pela criança, ela aparenta ser o desenvolvimento da criança ao inverso. Jakobson acreditava que a comparação entre a linguagem infantil e a afasia nos permite estabelecer diversas leis de implicação: as pesquisas que analisam as correlações sobre a ordem das aquisições e das perdas não deve ficar limitada ao sistema fonológico, mas sim estender-se a outros processos.

Apesar de essa teoria de Jakobson não ter se extendido à outras características da linguagem, vamos destacar uma questão sobre a aquisição da linguagem: o balbucio e a produção de palavras aparentemente são produzidos por atividade neuronal nas áreas corticais do lobo frontal inferior do córtex motor e áreas adjacentes pré-frontais. As articulações geram sons que ativam os neurônios no sistema auditivo, incluindo áreas no lobo temporal superior. Os feixes de fibras entre as áreas frontais superior e inferior provêm o substrato para o aprendizado associativo entre os neurônios que controlam programas motores específicos de discurso e neurônios no sistema auditivo cortical estimulados por sons da linguagem produzidos pelo próprio falante. O princípio de aprendizado de correlação afirma que a formação dessas associações específicas resulta em redes funcionais distribuídas pelo córtex perisilviano, que inclui as áreas principais de linguagem, inferior frontal e superior temporal. Esse conjunto de neurônios perisilvianos mais tarde proverá os mecanismos necessários para a ativação do programa de articulação de uma palavra como consequência de 
Capítulo 3. Redes de formas de palavras

estimulação acústica com a forma da palavra (Pulvermüller, 2002).

É interessante que o balbucio, ou seja, as primeiras articulações ligadas a linguagem da criança, comecem próximo aos seis meses de vida (Lumsden \& Locke, 1989) e seja imediatamente seguido pelo desenvolvimento de indicadores eletrofisiológicos de traços de memória para fonemas (Cheour et al., 1998) e a habilidade da criança de repetir palavras enunciadas por outros (Regier et al., 1993). Essas observações são consistentes com a ideia de que o balbucio é essencial para a construção de representações neuronais específicas da linguagem, em particular, ligações sensório-motoras que podem ser essenciais para a habilidade de repetição de palavras.

Indícios comportamentais sugerem que as crianças diferenciem os fonemas correlacionados e as sequências de sílabas inventando palavras através de sequências acidentais de som guardadas de inputs acústicos (Saffran et al., 1996). Portanto, parece provável que o input de uma palavra não seja necessário para a construção da representação de palavras, mas sim que as crianças possam usar correlações estatísticas, as probabilidades transacionais ou a informação mútua das sequências de fonemas e sílabas (Shannon, 2001) para aprender as palavras dentro de um discurso contínuo.

Depois que uma representação de palavra está estabelecida, a articulação repetida da palavra faz com que seja possível que as ligações sensório-motoras ativadas pelo balbucio estabeleçam a rede funcional ligada a palavra.

Isso ajuda a explicar o funcionamento de redes funcionais no cérebro, uma vez que a natureza das redes funcionais é de que os circuitos reverberatórios produzam ritmos de alta frequência quando são ativados (Pulvermuller et al. (1997); Milner (1974); Tallon-Baudry et al. (1999); Malsburg (1995)). Baseando-se nisso, Pulvermüller afirma que a previsão é que quando são introduzidas, as palavras ativem a rede funcional correspondente, portanto ativando ritmos de alta frequência. Do mesmo modo, pseudo-palavras que não fazen parte da linguagem não seriam capazes de ativar uma rede funcional e a atividade de alta frequência da área perisilviana deverá ser relativamente baixa. Num teste aplicado pelo autor, as respostas de alta frequência eram relativamente mais fortes quando apresentavam-se palavras da língua do falante, em oposição às não-palavras.

Diferenças entre palavras e pseudo-palavras foram encontradas em diversos estudos, segundo Pulvermüller, através do uso de técnicas de neuro-imagem eletrofisiológicas e metabólicas (Diesch et al. (1998); Hagoort 
\& Brown (1999); Rugg (1983)). O fato de que o cérebro distingue palavras da língua e itens sem significado é, portanto, incontroverso.

Aparentemente, o cérebro consegue distinguir palavras de pseudopalavras bem cedo, uma vez que informações relevantes estejam presentes no input. De acordo com Pulvermüller, estudos fisiológicos sugerem a existência de representações de palavras no cérebro.

\subsection{Redes de palavras de categorias específicas}

O uso de palavras no contexto de objetos e ações leva a associações entre neurônios nas áreas corticais da linguagem e neurônios adicionais em áreas de processamento da informação sobre os referentes dessas palavras. Isso é previsto baseado no princípio de correlação do aprendizado e nas conexões de alto alcance entre os sistemas sensório e motor (Pulvermüller, 2002). As redes funcionais poderiam, portanto, prover a base para a associação, no sentido psicológico, entre um nome de animal e a imagem visual que a ele se relaciona, ou entre um verbo e a ação que ele expressa. Ligações muito fortes dentro da rede podem ser o motivo pelo qual uma imagem é ativada automaticamente por uma forma de palavra apresentada e que, ao contrário, a imagem quase automaticamente chama o nome para a memória ativa. O conjunto de neurônios ligando a informação fonológica à informação sobre as ações e percepções a qual a palavra se refere são chamadas de rede de palavras. Elas incluem as redes fonológicas nas áreas perisilvianas e neurônios em áreas corticais mais espalhadas, criticamente envolvidas no processamento de percepções e ações, além de neurônios em várias áreas corticais onde informações relacionadas a ações e sensações convergem e se misturam. O tipo de entidade ao qual uma palavra se refere deve ser refletido na topografia cortical da rede funcional que o realiza.

\subsection{Palavras de ação e palavras relacionadas a imagens}

As modalidades sensório-motoras através das quais o referente de uma palavra é conhecido parecem ser relevantes. O que queremos dizer é que o significado do nome de um animal como "baleia" ou "tubarão", é geralmente conhecido através de experiências visuais como fotos ou filmes, 
enquanto o significado do nome de uma ferramenta como "prego" ou "garfo", refere a objetos que se usam para certas ações, e isso faz diferença para o processamento desses nomes. Isso não quer dizer que uma pessoa não poderia conhecer uma baleia através da interação, ou garfos através da imagem, mas parece plausível que na maioria dos indivíduos as informações mais relevantes para caracterizar baleias e garfos sejam relacionadas a imagens ou a ações, respectivamente. A princípio, para tirarmos conclusões sobre atributos perceptuais ou funcionais das palavras e das categorias conceituais, as associações de percepção e ação dos estímulos deve ser avaliada. Investigações de comportamento feitas com sujeitos sem alterações neurológicas revelaram que muitos nomes de animais e ferramentas apresentam as diferenças esperadas de associações visuais ou acionais. No entanto, a maior dissociação foi feita a respeito de atributos perceptuais e de ação entre verbos de ação e substantivos selecionados referindo-se a animais ou a objetos grandes, feitos pelo homem (Pulvermuller et al., 1999). Também, categorias como nomes de animais não foram bem definidas no que diz respeito à modalidade para qual as maiores diferenças foram encontradas. Por exemplo, enquanto palavras como "baleia" parecem gerar associações visuais primárias, os resultados para "gato" são menos efetivos. Portanto, as associações diferenciadoras das categorias sugerem uma análise mais filosófica (como seres vivos e não vivos).

Foi discutido que uma possível limitação dessa linha de pensamento é o fato de que ela só pode ser aplicada à comunicação, onde as palavras estão sendo aprendidas no contexto dos seus objetos e ações referentes. No entanto, significados de palavras também podem ser tirados de contextos nos quais os referentes reais estão ausentes. Os seus significados são revelados frequentemente por outras palavras usadas na mesma sentença ou no mesmo pedaço de discurso. Existem teorias que afirmam que o significado de uma palavra pode ser definido em termos de conjuntos de outras palavras que co-ocorrem frequentemente com ela (Landauer, 1999). Isso resultaria em um cenário diferente para o aprendizado do significado de uma palavra. Dado que existe um estoque de palavras cujos significados foram adquiridos baseados em relações de palavra-objeto ou palavra-ação, uma nova palavra que ocorra em boa relação com essas palavras, ativaria apenas a sua representação fonológica, porque nenhum elo semântico (relacionado à referência) teria sido estabelecido. No entanto, os neurônios na área extra perisilviana relacionados ao significado de contexto comum das palavras, frequentemente se ativa junto com a rede fonológica de uma 
nova palavra. A atividade correlacionada de neurônios semanticamente relacionados incluída nas representações neuronais de palavras de contexto conhecido e a rede fonológica da nova palavra podem permitir o aprendizado do significado da palavra. Claramente, isso significa que neurônios relacionados semanticamente serão compartilhados entre palavras previamente conhecidas e palavras novas, de forma que as suas representações neuronais se sobreporiam em suas partes semânticas. Essa linha de pensamento mostra que o aprendizado do significado de uma palavra baseado na atividade neuronal correlacionada não é restrita ao cenário palavra-objeto. O significado de palavras também pode ser aprendido por contexto.

\subsection{Topografia das redes de palavras}

As topografias diferentes das redes de palavras implicam em diferenças no processamento entre categorias de palavras. Uma grande fonte de indícios para essa afirmação vem de estudos neuropsicológicos em pacientes nos quais, por exemplo, a produção ou a compreensão de nomes e verbos ou nomes de animais ou ferramentas foram afetados diferentemente no cérebro (Perani et al. (1998); Miceli et al. (1988)). Essas dissociações entre tipos de palavras e categorias conceituais podem ser entendidas com base na afirmação de que conjuntos distribuídos de neurônios refletem atributos perceptuais e estruturais, incluindo características visuais e o grau de sobreposição entre exemplares, e os atributos funcionais, as ações as quais as palavras e os conceitos se relacionam (Humphreys \& Forde, 2001).

Uma pergunta que pode ser feita é se o cérebro humano intacto demonstra uma ativação diferente das áreas cerebrais quando palavras relacionada à ação ou à percepção estão sendo processadas. Um exemplo de predição é que se as palavras de um determinado tipo (visuais ou de ação) podem ser caracterizadas por associações visuais ou acionais mais fortemente do que as palavras do outro tipo, o seu processamento deveria ser acompanhado por uma atividade cerebral mais forte nas áreas relacionadas. Ou seja, uma palavra mais relacionada com uma associação acional ativaria áreas cerebrais relacionadas à parte motora, e palavras relacionadas a características visuais, ativariam áreas ligadas ao sistema visual.

Martin (1996) apresenta um teste no qual quando figuras de animais e ferramentas foram apresentadas em um teste de nomeação, várias áreas incluindo as clássicas áreas relacionadas à linguagem, tiveram a sua ativi- 
dade aumentada. Ativação de categoria específica foi encontrada no córtex pré-motor e no giro temporal médio quando ferramentas tiveram que ser nomeadas em silêncio, e no lobo temporal occipital e inferior quando animais tiveram que ser nomeados. Esses resultados estão de acordo com a previsão anterior, pode-se dizer que a ativação pré-motora está relacionada com a associação a ações feitas por causa dos nomes de ferramentas e que a ativação das áreas temporal inferior e occipital podem estar relacionadas aos atributos visuais dos nomes de animais.

Investigações neurofisiológicas do processamento de nomes e verbos proveram mais evidências para processos cerebrais de categoria específica relevantes para a linguagem. Em um desses estudos (Pulvermuller et al., 1999) associações visuais e de ação dos nomes e verbos selecionados foram demonstradas por todos os participantes.

A proposta dessa teoria é que existe um conjunto de células, ou rede funcional para cada palavra, e que palavras com significados referenciais diferentes podem ter redes funcionais caracterizadas por diferentes topografias. Essa proposta será retomada no capítulo 12, no qual apresentamos as propostas de interpretação para diferentes tipos de metáfora. 


\section{Capítulo 4}

\section{Regulação e sobreposição}

Uma proposta que será crucial para o desenvolvimento desse trabalho será a questão da sobreposição de palavras. Quando olhamos para as palavras mais de perto, relações de forma e significado mais complexas podem surgir. Duas palavras podem compartilhar a mesma forma (como "manga") ou podem ter sons diferentes mas terem mais ou menos o mesmo significado (carro e automóvel). Existem formas de palavras que incluem outras formas de palavra (como no inglês "nor", "no" e "or") e existem palavras que incluem, por assim dizer, o significado de outras (como animal e cachorro). Essas relações de homofonia (ou polissemia), homonímia (ou sinonímia) inclusão de formas de palavras em outras formas de palavras e hiperonímia (em oposição a hiponímia) podem gerar problemas para uma teoria que tenha por base redes neuronais corticais, já que essa teoria afirma que palavras específicas são localizadas em áreas específicas do cérebro, com seu correspondente grupo de neurônios. A seguir, explicaremos como as teorias exploradas aqui lidam com esses problemas e retomaremos o conceito de sobreposição de palavras dentro do léxico mental na apresentação dos resultados desta pesquisa para explicar porque este conceito parece ser relevante para tratarmos de diferenças entre palavras com sentido literal e não literal.

\subsection{Representações sobrepostas}

Redes funcionais que representem palavras relacionadas apresentam uma organização específica. Itens relacionados são organizados em conjuntos de 
neurônios corticais sobrepostos. Em geral esses mecanismos permitem que cada representação neuronal $\mathrm{x}$ se torne completamente ativa enquanto, ao mesmo tempo, evita que outros neurônios de conjuntos que se sobrepõem se tornem ativos. No jargão proposto sobre redes funcionais, a formulação mais precisa é a seguinte. A ignição de x evita que outras redes w, y, z... algumas das quais sobrepõem $\mathrm{x}$, sejam ativadas ao mesmo tempo que $\mathrm{x}$. As áreas de $\mathrm{x}$ que são compartilhadas por $\mathrm{w}$, y e z seriam ativadas como parte da ignição de $x$.

A seguinte proposta apresentada por Levelt (1989) é que representações distribuídas que se sobrepõem mas são mutualmente exclusivas são parte do processamento e representação de diferentes tipos de palavras relacionadas. Redes funcionais representando palavras individuais podem incluir:

- Uma forma fonológica localizada na área perisilviana da linguagem, fortemente lateralizada a esquerda.

- Uma parte semântica distribuída sobre várias áreas de ambos os hemisférios, cuja topografia pode depender de propriedades semânticas das palavras.

As duas partes, as sub redes fonológica e semântica seriam funcionalmente ligadas e, portanto, exibiriam uma dinâmica similar e uma dependência funcional mútua.

Palavras semanticamente relacionadas devem se sobrepor na parte semântica, amplamente distribuída e bi-hemisférica das suas redes funcionais, enquanto palavras fonologicamente relacionadas devem compartilhar neurônios na parte perisilviana lateralizada das suas redes funcionais.

A sobreposição entre representações explica porque palavras relacionadas em significado e forma podem influenciar ou ativar uma a outra. Nesse contexto, ativar significa que em investigações de processamento de palavras a apresentação de um item relacionado, também chamado ativador (prime), influencia o processamento do outro item relacionado que seja apresentado depois, geralmente chamado de alvo. Efeitos de ativação podem ser facilitadores ou inibitórios, ou seja, a ativação pode melhorar ou deteriorar o processamento da palavra alvo. Tanto palavras relacionadas semanticamente ou fonologicamente podem ter um efeito de ativação facilitador uma na outra (Humphreys et al. (1982); Meyer \& Schvaneveldt 
Homófonos e palavras de forma fonológica relacionada

(1971)). Deve-se mencionar, no entanto, que os paradigmas e, em particular, o começo com o qual as palavras estímulos são apresentadas podem ter um efeito na ativação da palavra alvo, facilitador ou inibidor (Levelt (1992) Mohr \& Pulvermuller (2002)).

\subsection{Homófonos e palavras de forma fonológica relacionada}

Uma palavra como "manga" possui pelo menos dois significados possíveis com pouca ou nenhuma relação um com o outro. Podemos nos perguntar como essas palavras homofônicas ou polissêmicas seriam organizadas num modelo de redes funcionais. A rede representando a palavra poderia desenvolver conexões com as partes neuronais de ambos os significados da palavra. Essas formas fonológicas deveriam, como já mencionado, estar localizadas no córtex perisilviano.

Agora o problema surge de que a percepção da palavra "manga" irá ativar ambas representações semânticas ao mesmo tempo. Isso não é o desejado, os dois significados possíveis devem ficar separados. Conceitualmente, seria melhor falar sobre duas representações de palavras, cada uma com seu significado específico, que compartilham a mesma representação fonológica. Do mesmo modo, parece apropriado postular dois conjuntos de neurônios, um para cada palavra que se sobrepõem na sua parte fonológica perisilviana.

Ainda segundo Levelt, a exclusão mútua das redes funcionais que se sobrepõem poderia ser providenciada por um mecanismo de regulação. O estímulo de uma palavra ativaria a parte fonológica compartilhada por duas redes funcionais representando a mesma palavra. Porque as partes semânticas de ambas as palavras estão fortemente conectadas à parte fonológica compartilhada, ambas recebem ativação. Acontece, então, uma corrida entre as duas redes de palavras sobrepostas, que finalmente termina com a ignição de uma delas, aquela que atingir o limite da ativação primeiro. O resultado da corrida é determinado pela força da conexão interna de cada uma das redes sobrepostas — a rede que possui o homófono mais frequente é mais passível de ser ativada primeiro - e pela atividade das redes devido a inputs no passado, por exemplo, pré-ativação da rede da palavra que melhor se encaixar no contexto. A ignição de uma das 
redes de palavras ativa o mecanismo de regulação, evitando a ativação do competidor. Mesmo assim, a rede competidora também ganha com esse processo de ativação, até que a ignição aconteça.

Esse cenário é reminiscente de ideias psicolinguísticas desenvolvidas com base nos estudos de ativação (Swinney \& Cutler, 1979). Estudos de tempo de reação indicaram que a apresentação da forma de uma palavra homófona primeiro leva à ativação parcial de todos os seus significados, enquanto num ponto futuro um deles será selecionado e os demais suprimidos. Redes de palavras sobrepostas e fortemente conectadas que se ativam umas às outras, mas que não conseguem dar ignição ao mesmo tempo devido aos processos de regulação podem ser o mecanismo por trás disso; ativação inicial parcial de todas as redes sobrepostas e depois a seleção da ignição de uma delas.

Esse mecanismo não é necessariamente restrito aos homófonos ou polissemas reais. O mesmo processo poderia estar por trás da decisão entre diferentes sub-significados ou usos de uma palavra em particular. "Escola", por exemplo, pode tanto se referir a um lugar, a um evento nesse lugar ("ele começa a escola às 9:oo") ou a um grupo de pessoas ("a escola de linguística de Praga”). Essas leituras são relacionadas mas de qualquer modo excluem umas às outras em contextos particulares. As suas contra partes neuronais sobrepõem redes que compartilham alguns dos seus neurônios em áreas perisilvianas, mas inibem umas às outras através do mecanismo de regulação.

\subsection{Protótipos e semelhanças de família}

Os significados de palavras podem ser organizados hierarquicamente. Palavras como "animal", "cachorro" e "labrador" referem a categorias de objetos mais amplas e mais estreitas, e portanto, um modelo baseado em redes funcionais deve conceitualizar seus significados como conjuntos de neurônios que envolvem uns aos outros. A categoria mais ampla - à qual o hiperônimo "animal" se refere - deve incluir a categoria menor - o hipônimo "cachorro". A parte semântica da rede do hiperônimo deve, portanto, incluir a parte semântica da rede do hipônimo. Claramente, a sobreposição de representações semânticas deve permitir a facilitação dos efeitos de ativação, enquanto outras alternativas de formas fonológicas de palavras podem ser a base para a competição. 
Protótipos e semelhanças de família

A afirmação de que a rede semântica mais geral de um termo é a união de todas as representações semânticas dos seus hipônimos precisa ser melhor explicada. As categorias de níveis mais baixos compartilham características, e as representações semânticas respectivas podem, portanto, ser conceitualizadas como conjuntos de neurônios de características semânticas que se sobrepõem. O nome da categoria de nível mais alto pode ser usado para se referir a todos os objetos que os hipônimos podem se referir. Portanto, a categoria de nível mais alto se correlaciona melhor com a sobreposição de características semânticas dos hipônimos.

Se uma figura de um objeto é apresentada a uma pessoa, e lhe é pedido que produza um nome para tal objeto, a corrida da ativação entre as representações de palavras possíveis seria novamente determinada pela força das conexões internas. O resultado da corrida depende da correlação entre os neurônios relevantes, e, portanto, na frequência com que tais palavras são usadas (a frequência lexical). Nomes de categorias de nível básico que ocorrem com frequência, como "cachorro", podem ser preferidas em oposição a palavras mais raras e mais específicas como "labrador". Enquanto uma categoria de nível mais alto vai perder a corrida para uma palavra de termo mais específico ("animal" em oposição a "cachorro") por causa da melhor correlação entre o conjunto específico de características semanticamente relacionadas ativadas.

A correlação entre as características semânticas a que essas palavras se relacionam é necessariamente baixa, resultando numa baixa média de ligações dentro da parte semântica das suas redes. A rede de palavra de "cachorro", portanto, seria ativada muito mais rápido do que o termo mais geral "animal" - por causa da sua melhor correlação significado-forma, e também mais rápido do que o termo "labrador" por causa da maior frequência lexical.

As fronteiras das redes funcionais não são necessariamente fáceis de definir. A palavra "animal", cujo significado pode ser pensado como a união de todas as características dos seus hipônimos, teria a união de partes de redes semânticas dos seus hipônimos como seu equivalente neural. Em contraste com essa vasta definição, pode-se argumentar que apenas a região de sobreposição semântica de neurônios compartilhada por todas as redes dos hipônimos deveria representar o significado central do termo mais geral. O problema com esse ponto de vista é que a sobreposição de todas as redes semânticas de hipônimos pode não ser muito específica.

Esse é o argumento fundamental de Wittgenstein (1974) sobre as seme- 
Significado afetivo e emocional

lhanças de família. O significado de uma palavra em diferentes contextos não necessariamente possui um cerne semântico comum. Os diferentes significados podem apenas lembrar uns aos outros como membros de uma família, sem compartilhar um conjunto de características ou genes. Do mesmo jeito, o conjunto semântico de neurônios representando os diferentes significados dependentes de contexto da palavra "animal" podem não ter uma sobreposição relevante.

Isso levanta questões sobre a definição dos conjuntos de células e redes funcionais. A implicação dessas considerações é que um conjunto de células ou rede funcional não deve ser conceitualizado como um conjunto estático de neurônios com limites bem definidos (Braitenberg (1978); Posner \& DiGirolamo (2000)). Dependendo de atividades corticais anteriores e ativações da rede, mais ou menos neurônios podem se envolver na ignição de uma dada rede funcional.

Essas considerações mostram que o ponto de vista "rede funcional= palavra" gera algumas questões teóricas. Uma conclusão necessária é que redes funcionais não deveriam ser entendidas como conjuntos de neurônios constantes, com barreiras estabelecidas que sempre são ativadas e reverberam do mesmo modo. Apesar do centro da forma de uma palavra e os neurônios semanticamente relacionados poderem sempre estar incluídos na ignição, existem neurônios nos limites do conjunto, por assim dizer, que podem ou não tomar parte na ignição. A sua inclusão ou exclusão depende do contexto - de atividades anteriores e atividades presentes na rede.

Acreditamos que a relação entre palavras homófonas possa ser aplicado às metáforas. Obviamente, as metáforas compartilham uma mesma estrutura fonológica com o seu significado literal, no entanto, a diferença entre elas e as homonímias é que as metáforas compartilham também traços semânticos com a sua forma literal, o que poderá alterar o seu acesso se pensarmos nessa "corrida" de ativação proposta por Levelt, ou seja, apesar de haver uma conexão entre uma palavra como "tartaruga" e o seu correspondente metafórico, as vias de acesso para a ativação de uma ou de outra podem não ser as mesmas. Retomaremos este assunto no capítulo 12.

\subsection{Significado afetivo e emocional}

Existem indícios de estudos clínicos de que haja o envolvimento de circuitos talâmicos e estriatais no processamento da linguagem. A produção de 
palavras com propriedades afetivas e emocionais pode ser representada por neurônios na amígdala e no mesencéfalo. Existem várias tentativas de explicação para o sucesso variável de estudantes que começaram a aprender uma segunda língua quando já eram mais velhos. Uma proposta afirma que há diferentes ligações de abas da amígdala e do mesencéfalo com as redes de palavras. Apenas se o processamento de palavras e atividade subcortical relacionada emocionalmente forem correlacionadas, a rede de palavras de um estudante poderia gerar abas da amígdala e do mesencéfalo. A ativação dessas redes inundaria o cérebro de dopamina, possibilitando a facilitação do aprendizado de questões relacionadas com a linguagem. Portanto, uma pessoa aprendendo uma segunda língua que já tenha adquirido algumas redes de palavras ligadas com a amígdala e o mesencéfalo pode ter mais facilidade para o armazenamento de informação, incluindo informações ligadas à gramática e à linguagem quando essas redes estiverem ativas.

Apesar de essa proposta ter levado a esforços de pesquisa que geraram dados consistentes com as ideias básicas tanto do nível comportamental (Schumann, 1999) e do nível de investigação neurofisiológica (Silverman et al., 1996), uma investigação sistemática usando imagens cerebrais ainda espera por futuras pesquisas. 


\section{Capítulo 5}

\section{Entradas lexicais}

Nos capítulos anteriores vimos brevemente algumas questões relacionadas ao processamento da linguagem no cérebro. Neste capítulo, apresentaremos uma teoria sobre como a estruturação das palavras aconteceria dentro dessa base neurológica.

Segundo Levelt (1989), a formulação de processos seria comandada pelo léxico. Isso significa que as codificações fonológica e a gramatical seriam mediadas por entradas lexicais. A mensagem pré-verbal dispara os itens lexicais. As propriedades sintáticas, morfológicas e fonológicas de um item lexical disparam por sua vez os procedimentos de codificação que baseiam a geração do discurso. A afirmação de que o léxico é um mediador essencial entre a conceitualização e a codificação gramatical e fonológica é a chamada hipótese lexical. Essa hipótese considera que nada na mensagem do falante irá por si só desencadear uma forma sintática em particular, como uma construção passiva ou dativa. De acordo com essa teoria, sempre deve haver itens lexicais mediadores disparados pela mensagem, que com suas propriedades gramaticais e sua ordem de ativação, fazem com que o codificador gramatical gere uma estrutura particular.

\subsection{A estrutura interna de uma entrada lexical}

O léxico mental de um falante é um depósito de conhecimento declarativo das palavras da sua língua. Do ponto de vista da produção da linguagem, cada item lexical carrega pelo menos quatro traços: (1) o primeiro é a especificação do significado, um grupo de condições conceituais que deve 
ser preenchido na mensagem para que este item seja selecionado.(2) Há também o grupo de propriedades sintáticas, incluindo suas categorias (verbo, por exemplo), os argumentos sintáticos que podem exigir (um sujeito e um objeto, por exemplo) entre outras propriedades. Certos itens do léxico são ativados durante a codificação gramatical quando suas condições sintáticas são preenchidas. (3) Em terceiro, está a especificação morfológica do item e em (4) quarto está a especificação da forma, a composição do item lexical em termos de segmentos fonológicos.

Existem, provavelmente, outras propriedades dentro de um item lexical. Ele pode ter propriedades pragmáticas, estilísticas e afetivas que o tornam melhor para determinados contextos e não para outros, como discursos formais ou informais. Um dos pontos que pretendemos demonstrar com esta pesquisa é que as propriedades pragmáticas são cruciais para o acesso a determinados itens lexicais. No capítulo 12 veremos a análise dos dados obtidos com as entrevistas feitas com os sujeitos afásicos, nos quais mostraremos a relevância do contexto para o acesso lexical. Por enquanto, a fim de apresentar uma teoria que mostre a relação entre palavras dentro do léxico mental a sua ativação, vemos neste capítulo algumas explicações que, acreditamos, podem ser aplicadas no processo de produção de metáforas.

\subsection{Relações entre itens no léxico mental}

As entradas lexicais no léxico mental não são ilhas, o léxico possui uma estrutura interna. Os itens são conectados de várias formas, existem relações dentro das entradas lexicais e entre elas.

Nem todos os itens lexicais são entradas lexicais. As várias flexões de um verbo são itens que pertencem à mesma entrada lexical, por exemplo, e eles são relacionados dentro dessa entrada lexical. Os traços diacríticos para pessoa, tempo, número, modo e aspecto vão ser responsáveis por selecionar o item certo dentro de uma entrada lexical, Levelt admite que, em geral, é assim que acontece com as flexões.

As relações entre entradas lexicais no léxico mental são de dois tipos: intrínsicas e associativas. As relações intrínsecas derivam dos quatro tipos de traços de uma entrada (ou seja, significado, sintaxe, morfologia e forma).

Primeiro, os itens têm conexões especiais no que concerne ao significado. Há evidências na literatura de que essa conexão existe entre uma palavra e a sua hiperonímia (cachorro - animal, por exemplo), entre uma palavra e sua 
co-hiponímia (cachorro - gato), e entre uma palavra e seu quase sinônimo (perto - próximo) (Smith \& Medin, 1981). Grupos de itens relacionados semanticamente são chamados de campos semânticos. Dentro dos casos de anomia isso pode ser observado claramente devido à produção de parafasias (veremos alguns exemplos no capítulo 10).

Em segundo, conexões determinadas morfologicamente podem se dar entre entradas com a mesma raiz. Essas entradas são chamadas de relacionadas derivacionais (como nação - nacional). Obviamente, há quase sempre relações de significado também entre essas palavras.

Em terceiro temos as conexões fonológicas entre as entradas no léxico mental. Palavras que começam ou terminam com o mesmo som mostram conexões na produção do discurso, algumas vezes levando a erros. Isso sugere que palavras fonologicamente parecidas estão conectadas no léxico mental

E em quarto, existem indícios (segundo Levelt, não convincentes) de que haja condições relacionadas sintaticamente dentro do léxico mental. Todos os substantivos, ou verbos transitivos poderiam ser, portanto, mutualmente conectados. Isso pode ser observado em casos neurológicos, existem casos em que todos os substantivos se tornam inacessíveis para a produção.

A natureza das relações intrínsecas é uma questão a ser discutida. Pode haver conexões diretas entre os itens lexicais, ou elas podem ser mediadas. Uma relação semântica direta, por exemplo, seria uma na qual as co-hiponímias seriam listadas com esse item, ou seja, a entrada "verde" conteria uma lista de co-hiponímias para "vermelho", "azul" e assim por diante. Já uma relação semântica mediada seria aquela em que existe uma relação entre os conceitos VERDE e AZUL, mas sem referência às entradas lexicais "verde" e "azul".

Relações associativas entre entradas lexicais não são baseadas necessariamente em suas propriedades semânticas, essa relação se dá devido a frequente co-ocorrência desses itens na produção de um discurso (como "armas" e "guerra", por exemplo).

Apesar de essas conexões serem inicialmente mediadas por relações conceituais complexas, elas se tornam associações diretas entre itens lexicais. Quando um item é utilizado, o outro será engatilhado, mesmo que a conexão do conceito original não esteja em questão no discurso que se está produzindo.

Algumas relações de significado intrínseco também podem desenvolver relações associativas, uma vez que itens relacionados no significado 
Espalhamento da ativação

frequentemente tendem a ocorrer dentro do mesmo discurso. Antonímias como esquerda e direita e pequeno e grande são alguns exemplos (Clark, 1970).

\subsection{Espalhamento da ativação}

Antes de passarmos para a fase de ativação de palavras, é preciso entender como os lemas (as formas canônicas de uma palavra) são ativados.

$\mathrm{O}$ autor afirma que uma explicação sobre como acontece a ativação dos lemas seria uma distinção dos itens que se quer nomear no nível conceitual. Os componentes conceituais que serviriam para acessar o conceito de "cadeira", por exemplo, podem ser: tem assento, tem encosto etc. Essas propriedades podem ser consideradas como input nodes, que podemos chamar de A, B, C etc. Nessa perspectiva, um conceito seria simplesmente uma coleção desses elementos ativados. Levelt chama essa representação de representação distribuída. O resultado dessa ativação de elementos será o lema, que será o próximo passo para a ativação de uma palavra depois da sua ativação conceitual.

$\mathrm{O}$ autor se limita a fazer duas observações a esse respeito: a primeira é que o espalhamento da ativação é um excelente candidato a dar conta das limitações de tempo real, pois o número de passos que devem ser dados do input ao output será de um ou, no máximo, dois. A segunda observação é que até agora não se sabe muito sobre a convergência. Não só não sabemos sobre qual estrutura se dá essa ativação, também não sabemos como resolver o problema da hiperonímia. Na seção 3.3 pudemos observar algumas considerações a esse respeito quando falamos sobre as redes funcionais, e, a seguir, veremos como a ativação de diferentes itens lexicais poderia ser explicada.

Para resolver a questão da hiperonímia, Levelt propõe três princípios que, segundo ele, se incorporados no modelo de processamento, garantirão a convergência correta entre um termo e seu hiperônimo.

Para entendermos esse princípios é necessário antes compreendermos a noção de essência. O significado essencial de um lema ou a condição conceitual de essência é o seu componente mais saliente e privilegiado. (Miller, 1969) sugeriu o teste da negação para determinar a essência de um lema.

A ideia desse teste é que a negação irá, quando não houver restrição 
Espalhamento da ativação

no conjunto de alternativas, afetar apenas a essência de uma palavra. Um exemplo apresentado por Levelt é o de um teste feito com verbos de movimento. Numa frase como "ele não esquia, mas ele..." nenhuma das respostas foi um verbo do tipo "pensa" ou "respira", a resposta mais frequente foi "patina". Aparentemente, os sujeitos aplicam o mínimo de negação, tanto que o maior sentido de "esquiar" seja preservado sob a negação. Nesse caso "esquiar" e "patinar" denotam uma forma de locomoção sobre uma superfície congelada, envolvendo um equipamento preso aos pés. Sobre os dois verbos em questão, apenas o instrumento é diferente, o caráter do instrumento é o único componente conceitual modificado pela negação. Por esse teste, descobriríamos, portanto, a essência do lema para "esquiar", Miller chamou a parte não modificada (no caso, o significado compartilhado por "esquiar" e "patinar") de pressuposição do lema. Obviamente, esse teste não é infalível, quando as alternativas do discurso estão limitadas ao contexto: se soubéssemos que o João só trabalha e esquia uma frase do tipo "João não está esquiando, está trabalhando" seria a resposta natural.

Levando tudo isso em consideração, o primeiro princípio apresentado pelo autor é o princípio da unidade. Ele diz que nunca dois itens lexicais podem ter o mesmo significado essencial. Em outras palavras, existem tantos significados essenciais quanto existem itens lexicais. O que nos leva ao segundo princípio: o princípio da essência, ou seja, que um item lexical só é acessado se sua condição essencial for satisfeita pelo conceito que se quer expressar.

Este último não é um princípio muito forte, mas é um passo em direção à solução do problema da hiperonímia, isso porque pelo segundo princípio, um termo e o seu hiperônimo nunca terão a mesma essência. Ou seja, no caso de "esquiar" e "patinar", ambos são formas de "deslizar", portanto, essa é a forma superior desses verbos. A essência de "deslizar" parece ser a característica de um movimento contínuo e leve. Portanto, "esquiar" e "deslizar" possuem essências diferentes, e se um falante quiser expressar a noção de "deslizar" não poderá usar um de seus subordinados.

Mas o contrário ainda pode acontecer, ou seja, se a noção de "esquiar" está dentro da noção de "deslizar" e um falante quer expressar essa noção, então "deslizar" poderia ser usado em lugar de "esquiar". Por isso precisamos do terceiro princípio para prevenir o acesso ao hiperônimo: o princípio da especificidade, que diz que de todos os itens cujas condições são satisfeitas pelo conceito, o mais específico será o acessado. Desse modo, 
a palavra "esquiar" é impedida de ser ativada quando o conceito "esquiar" for o alvo do discurso.

Esses princípios são reminiscências das máximas de quantidade de Grice.

O acesso lexical, então, envolve essencialmente o reconhecimento dos predicados principais de um conceito e descobrir qual é o lema único que as possui como condições essenciais. Essa teoria será fundamental para explicarmos o uso das metáforas. Retornaremos a ela no capítulo 12. 


\section{Capítulo 6}

\section{Acesso Lexical e Falhas de Acesso Lexical}

Esta pesquisa trata principalmente de questões relacionadas ao acesso lexical dos falantes de uma língua. Para caracterizarmos os problemas que podem ser enfrentados por um sujeito afásico cuja habilidade para recuperar palavras no léxico mental foi alterada, é preciso que determinemos, antes, como os passos para a concretização desse processo se dariam numa situação não-patológica.

Segundo Levelt (1989), ao planejar um enunciado existe uma fase inicial para o falante na qual é decidido o propósito para o seu próximo movimento. Essa decisão vai depender de um conjunto de fatores e das necessidades, crenças e obrigações do falante. A escolha do falante se relaciona em particular com o que foi dito antes na conversação, do que ele deve ter mantido alguma lembrança. A elaboração de uma intensão colaborativa de um falante, feita através da seleção da informação cuja expressão pode alcançar os objetivos comunicacionais será chamada de macroplanejamento. O planejamento de atividades conceituais, ou seja, o planejamento de uma perspectiva informacional, será chamado de microplanejamento (o tópico, o foco, como chamar a atenção do interlocutor e assim por diante). O macroplanejamento envolve a elaboração de algum objetivo comunicativo em uma série de subobjetivos e o acesso à informação a ser expressada para que se alcance cada um desses subobjetivos. O microplanejamento atribui a forma proposicional adequada à cada uma dessas partes da informação (os subobjetivos), assim como a perspectiva informacional (o tópico e o foco) que vai guiar a atenção do interlocutor. 
Ou seja, existem razões para distinguirmos duas fases do planejamento de uma enunciação depois que uma intenção comunicativa foi concebida. Durante o macroplanejamento, o falante seleciona e molda a informação de modo que a sua expressão seja um meio apropriado para transmitir a intenção. Nessa fase, o falante detalha a sua intenção comunicativa e introduz a informação apropriada cuja expressão vai revelar a intenção para o interlocutor. Isso fixa um ato de fala, isto é, o compromisso que o falante está preparado para fazer através da expressão de um conteúdo particular de informação bem como dos níveis escolhidos de franqueza e polidez. Esses pedaços de informação não são independentes.

O modo como um falante mapeia o pacote de informação a ser expressado em palavras envolve, é claro, o acesso a itens lexicais, os quais Levelt vai chamar de léxico mental — o armazém de informação sobre as palavras de uma língua. O falante irá utilizar partes da estrutura conceitual para acessar as palavras apropriadas (isto é, os itens lexicais que expressam corretamente os significados pretendidos) do léxico.

Um item lexical é uma entidade complexa, ele é acessado através do seu significado, mas também contém informações sintáticas, morfológicas e fonológicas.

Há indícios de que o falante construa a estrutura de uma enunciação sem muita preocupação com a parte fonológica das palavras. Além da informação semântica, ele utiliza a informação sintática (e algumas vezes aspectos da informação morfológica) contidos nos itens acessados para construir essa estrutura. Essa parte não-fonológica da informação de um item lexical será chamada da informação lema (ou apenas lema) de um item. Portanto, quando dissermos que um falante acessou um lema, queremos dizer que o falante conseguiu acessar aqueles aspectos da informação da palavra armazenada que são relevantes para a construção do ambiente sintático dessa palavra.

Em resumo, para produzir uma enunciação, o falante segue os seguintes passos: há a escolha inicial do propósito (concepção da intenção) e há a seleção dos meios para fazer essa intenção aparente para o interlocutor. Esses processos conceituais dependem do estado de motivação do falante, do conhecimento compartilhado com os interlocutores, e, especialmente, a lembrança do discurso do falante. Eles criam uma mensagem a ser expressa. Além disso, existem outros passos linguísticos a serem percorridos. Palavras devem ser acessadas, formas sintáticas que mapeiam os conceitos e suas relações em uma estrutura de superfície gramatical devem ser construídas. 
Falhas de acesso lexical

Essas estruturas de superfície, por sua vez, têm que ser desenvolvidas em planos fonéticos que servem para instruir o aparato articulatório do falante. Acima de tudo, o falante ainda consegue monitorar e, se necessário, alterar o que está fazendo.

Quanto ao acesso à lunguagem não-literal, é preciso lembrar que os falantes de uma determinada língua possuem mais do que um estoque de palavras, eles possuem também um estoque de expressões idiomáticas, gírias e metáforas. Alguns conceitos são mapeados diretamente nesses sintagmas: a diferença entre "estar no vermelho" e "estar no azul" não está nas cores, esses sintagmas têm sentidos idiomáticos, e isso acarreta restrições sintáticas. Uma expressão como "abotoar o paletó" não tem um sentido transparente, é preciso estar inserido numa cultura para entender o que isso significa. Restrições sintáticas podem ser aplicadas no sentido em que pode-se dizer "ele abotoou o paletó", mas dificilmente alguém dirá "o paletó foi abotoado por ele" ou "ele está abotoando o paletó", apesar de ser possível dizer "ele está morrendo".

Não existe muito na literatura sobre como essas expressões são geradas. Segundo Levelt, elas devem ser tratadas como entradas no léxico mental, simplesmente. Cada entrada pode consistir em um item ou mais, e no caso de "abotoar o paletó", construções em determinados tempos verbais ou na voz passiva, por exemplo, não estão inseridas nas suas características. Expressões idiomáticas, assim como as palavras, têm suas condições características conceituais, se uma condição é preenchida para uma mensagem, então a expressão será acessada.

\subsection{Falhas de acesso lexical}

Agora que já apresentamos uma breve explicação sobre as fases do acesso lexical, podemos começar a descrever o que pode acontecer quando existem problemas no desenvolvimento desses passos. Segundo Levelt (1989) existem três classes de erros a serem discutidas sobre esse assunto, as quais apresentam características diferentes em seu processo de produção. As duas maiores causas de erros no acesso a palavras são: invasão conceitual e invasão associativa. A invasão conceitual acontece quando a seleção do lema é perturbada pela atividade simultânea de dois ou mais conceitos, enquanto a invasão associativa acontece quando a seleção do lema é perturbada pela ativação de outros lemas, também conhecida como associação 
Falhas de acesso lexical

de palavras. Não necessariamente o elemento intruso será relacionado semanticamente com o elemento alvo.

\subsubsection{Tipos de falhas de acesso lexical}

Existe mais de um tipo de falha de acesso lexical. Levelt cita três deles: mesclagem de palavras, troca de palavras e substituição.

\section{Mesclagem de palavras}

Em uma mesclagem de palavras, duas palavras são fundidas em uma só, ou seja, dois lemas são acessados que competem para uma mesma base. Semanticamente falando, existem dois tipos de mesclagem, o primeiro envolve palavras de significado parecido e o segundo envolve o que o autor chama de distrações. Exemplos do primeiro tipo são:

(1) The competition is a little stougher [stiffer/tougher] (Fromkin, 1973) "A competição está um pouco mais durícil" [dura/difícil]

(2) Irvine is quite clear [close/near] (Fromkin, 1973)

"Irvine está bem pérxima"[perto/próxima]

(3) At the end of today's lection [lesson/lecture] (Garrett, 1976)

"No final do paulestra de hoje"[aula/palestra]

Vale a pena comentar o fato de que essas palavras sejam mais ou menos equivalentes dentro do contexto da mensagem. Aparentemente, essas palavras passam por uma associação conceitual quando são ativadas. No entanto, não é uma característica de palavras mescladas que elas sejam associadas desse modo, pode acontecer ou pode não acontecer que elas tenham um significado parecido. A etiologia da mistura de palavras parecidas, segundo Levelt, é que a mensagem em si contém uma certa ambivalência no que diz respeito a dois conceitos igualmente apropriados, que podem ser chamados de planos alternativos. Esses conceitos acessam os seus lemas quase simultaneamente e ambos os itens lexicais são ativados e inseridos na superfície da estrutura. Isso induz as suas formas a se misturar no nível de processamento fonológico. 
O mesmo pode ser dito das mesclagens por distração. Um falante que esteja tentando ativar um conceito específico pode ter o caminho invadido por uma distração ou alguma outra causa. Nesse caso, um outro conceito com um outro lema pode ser ativado, e se tanto o lema alvo como o invasor forem ativados ao mesmo tempo, uma mistura desse tipo pode surgir, como no exemplo:

(4) Dann aber sind Tatsachen zun Vorschwein [Vorschein/Schweinereien] gekommen. ${ }^{1}$

Mas os fatos vieram à tona/imundície.

O falante dessa frase concordou que estivesse pensando em "imundície" no momento da enunciação. Obviamente, não havia relação entre os dois conceitos envolvidos, nem associação às duas palavras.

Duas palavras misturadas são, geralmente, pertencentes à mesma categoria sintática. A primeira vista isto poderia ser surpreendente, uma vez que a afirmação é que as palavras são acessadas devido apenas às suas especificações conceituais, a categoria sintática deveria ser irrelevante, e lemas de categorias sintáticas diferentes deveriam se passíveis de serem amalgamados. No entanto, devemos imaginar o que aconteceria se itens lexicais de categorias diferentes competissem entre si. Eles não podem aparecer no mesmo ambiente frasal por causa da diferença de categoria, portanto, ou as restrições frasais serão tais que apenas o lema de um categoria específica pode ser acessado, ou cada lema vai engatilhar a construção do seu próprio ambiente frasal, e uma mistura pode acontecer.

\section{Substituições}

Substituições de palavras podem acontecer de vários modos. A seguir apresentamos alguns exemplos:

(5) Don't burn your toes [fingers - toes] (Fromkin, 1973)

Não queime seus dedos do pé [dedos da mão — dedos do pé]

\footnotetext{
${ }^{1}$ Observado por Mayer e Freud, e citado por Meringer e Mayer 1895 e Freud 1904.
} 
Falhas de acesso lexical

(6) I just put it in the oven at a very low speed [temperature - speed] (Garrett, 1976)

Eu só ponho isso no forno numa velocidade bem baixa [temperatura — velocidade]

Esses exemplos são enviesados, uma vez que em todas as substituições a palavra substituta tinha alguma proximidade com a palavra alvo; substituições não relacionadas também podem acontecer, mas é mais frequente que isso ocorra entre palavras que mantém uma relação semântica. Resta saber, então, se a invasão é conceitual ou associativa.

Os casos mais frequentes observados envolvem antônimos ou outros casos de oposição semântica, ou co-hipônimos, isto é, palavras do mesmo campo semântico. A lista de Fromkin (1973) apresenta vários exemplos de substituições nessas linhas, como: "last-first"("primeiro-último"), "winebeer"("vinho-cerveja"), "later-earlier"("mais tarde- mais cedo"), "comegone"("ido-vindo"), "little-much" ("pouco- muito") e "sun- world"("solmundo").

Esses exemplos mostram que a substituição de palavras, diferente da mesclagem, geralmente reflete relações associativas.

Levelt sugere que uma das razões possíveis para a ativação do lema similar e não a do lema alvo seja a frequência com que essa palavra aparece no discurso. Segundo ele, uma palavra de alta frequência tem mais chances de substituir uma palavra de baixa frequência do que o inverso. $\mathrm{O}$ autor percebeu isso após analizar uma lista de substituições de Fromsky, usando listas de frequência de palavras de Kucera \& Francis (1967). Na lista de substituições havia vinte e três casos em que a palavra alvo era claramente associada semanticamente com a substituta. Desses casos, dezessete seguiram o caminho previsto por ele, apenas seis não. Essa é uma diferença significativa, mas Levelt afirma que essa pressuposição não pode ser feita em todos os casos de substituição, apenas naqueles em que a proximidade semântica entre a palavra alvo e a palavra substituída for clara.

Uma outra pergunta que podemos nos fazer é se não há casos de substituição em que há uma invasão conceitual. Nos casos de mesclagem, a invasão conceitual é muito comum, no entanto, nos casos de substituição são mais raras (sinônimos e hiperônimos não aparecem no corpus analisado por Levelt). A resposta do autor para essa pergunta é que simplesmente em casos de quase sinônimos não importa qual palavra é acessada primeiro. 
Em ambos os casos, as palavras serão apropriadas e ninguém vai reparar que houve uma corrida entre os dois processos de ativação. Em mesclagens, no entanto, as palavras se misturam, então isso soa como um erro aos ouvidos. Em substituições, nada tão perceptível acontece, não se pode negar que um quase sinônimo pode substituir a palavra alvo.

Podemos usar esse mesmo argumento para explicar porque hiperônimos também quase não aparecem em substituições, ao menos em parte. Não há como saber se um falante pretendia dizer "cachorro" quando disse "animal", frequentemente isso não será notado, mas o falante pode se incriminar se se corrigir. Uma análise de correções espontâneas de falantes (Levelt, 1983) mostra que não é incomum que um falante se corrija e opte por uma palavra mais específica.

Existem casos de substituição que não sejam relacionados. Levelt observou dois casos de Fromkin que parecem ser desse tipo:

(7) A branch falling on the tree [roof-tree]

Um galho caindo na árvore [telhado — árvore]

(8) Q: When are you going to have the ale?

Quando você vai tomar a cerveja?

A: With the beer [dinner-beer]

Com a cerveja [jantar-cerveja]

Nesses exemplos, "árvore" não é uma palavra semanticamente associada a "telhado", mas é uma palavra associada a "galho", portanto, lemas recentemente ativados que não sejam a palavra alvo também podem causar a invasão por um lema não pretendido, porém associado, esse caso não é de modo algum pouco frequente (Harley, 1984).

\section{Trocas de palavras}

Trocas de palavras, segundo Levelt, surgem devido a diferentes fragmentos de palavras sendo ativados ao mesmo tempo. Dois exemplos característicos são:

(9) Well, you can cut rain in the trees. [rain-trees] (Garrett, 1976) 
Bem, você pode cortar chuva nas árvores [bem, você pode cortar árvores na chuva]

(10) This spring has a seat in it. [spring-seat] (Garrett, 1976)) Essa primavera tem um banco nela [esse banco tem a primavera nele]

Segundo Levelt (1989) em trocas de palavras é quase acidentalmente que as palavras são relacionadas. Tipicamente elas expressam conceitos diferentes que estão prestes a serem formulados, principalmente como parte da mesma frase. Trocas de palavras são a evidência mais clara para o paralelismo, ou seja, para o acesso simultâneo de lemas diferentes por fragmentos diferentes da mensagem. Tal paralelismo de processamento provavemente contribui para a rapidez e fluência do discurso, mas também contribui para a possibilidade de acidentes.

Em trocas de palavras desse tipo, as palavras trocadas são sempre da mesma categoria sintática. Isso é o que se espera se a inserção de um lema na estrutura superficial em desenvolvimento necessitasse de uma categoria sintática que servisse a esse propósito. Garrett (1976) observou que as palavras trocadas pertencem a sintagmas diferentes e ocupam papéis parecidos em seus próprios sintagmas. É difícil definir o que é uma posição parecida, mas algo funcional parece estar em questão. Frequentemente, os elementos são núcleos de frase, e tendem a ser similares quanto aos argumentos temáticos que eles expressam ou nas funções gramaticais que preenchem.

Os tipos de falha de acesso, assim como os exemplos citados acima, tratam de situações de fala não-patológicas, no entanto, veremos eles podem ser aplicados ao discurso dos sujeitos afásicos. 


\section{Capítulo 7}

\section{Afasias}

O estudo científico da linguagem se proliferou na segunda metade do século XIX, além de linguistas e psicólogos, neurologistas passaram a se concentrar na linguagem dentro do contexto das então novas descobertas sobre a afetação do discurso devido a danos cerebrais. Em adultos que antes possuíam a completa habilidade de produzir e compreender sua língua nativa, um derrame, um tumor ou um trauma foram as causas da redução de suas habilidades linguísticas. Esses distúrbios de linguagem foram nomeados de afasia. Até hoje existem discussões sobre se realmente existem subtipos de afasia e uma boa parte de estudos relacionados ao tema foi dedicada ao desenvolvimento de novos esquemas de classificação e argumentação de por que um esquema refletia melhor a verdade do que outro. O resultado dessas pesquisas levou a inúmeros esquemas de classificação (Caplan, 1987) e uma extrema posição expressa pela afirmação de que existe apenas um tipo de afasia (Marie, 1906).

Esse último ponto de vista pode ser baseado nas características comuns a todas ou à grande parte das afasias. Todos os afásicos apresentam alguma dificuldade de fala, mais ou menos severa, ainda que a habilidade de articulação dos músculos possa estar bem preservada.

Existem casos de pacientes que apresentaram déficits apenas na produção de linguagem oral, ou apenas na compreensão de alguns aspectos da liguagem falada (Heeschen \& Kolk, 1988), mas sem levar em conta essas poucas exceções, as afasias parecem ser multimodais, ou seja, elas incluem déficits na produção e compreensão da linguagem falada e também em leitura e escrita. A característica multimodal da afasia pode ser usada em favor do argumento de que existe apenas um tipo de afasia e aspectos mais 
ou menos pronunciados em cada caso.

No entanto, se o foco está na diversidade dos problemas que os pacientes de fato exibem, faz sentido que se faça distinção de diferentes síndromes de afasia. A diferenciação mais óbvia é entre os afásicos cuja dificuldade principal está na produção da linguagem e afásicos que apresentam maior dificuldade na compreensão. Aqui podemos distinguir entre afasia motora e afasia sensorial (Pulvermüller, 2002) ou afasia expressiva e afasia receptiva (Berndt et al., 1983), ou como também são conhecidas, afasias de Broca e afasia de Wernicke, referentes a essas variantes e aos dois neurologistas que as descreveram. Além dessas duas síndromes, existem também a afasia total ou global, que é bastante severa, e um distúrbio causado principalmente pela dificuldade de encontrar palavras chamado afasia amnésica ou anomia. Outras síndromes de afasia mais detalhadas foram propostas com base em estudos teóricos de processamento da linguagem no cérebro.

Afasia é o nome que se dá ao prejuízo da compreensão e formulação da linguagem causado por uma disfunção em regiões específicas do cérebro (Damasio \& Damasio, 1992). Quando se fala em afasia, os aspectos que devem ser considerados são as funções de linguagem corretamente adquirida e, até então, intacta, gerenciadas pelo hemisfério dominante (geralmente o esquerdo, mas existem casos de hemisfério dominante direito).

Do ponto de vista clínico, as afasias são classificadas de acordo com sua definição sindrômica. Esse tipo de classificação é problemático, pois na realidade os fatos que geralmente são considerados isoladamente fazem parte de um todo no qual esses sinais independentes são apenas proeminentes em cada tipo de afasia considerado (Mansur, 2004).

Embora apresente algumas dificuldades, a classificação das afasias tem utilidade prática na medida que oferece uma troca de informações padronizadas entre os profissionais que cuidam do assunto, sobre o quadro clínico, a localização anatômica e a evolução do déficit.

Uma das vantagens apresentadas por Mansur e Radanovic (2004) é a facilidade de correlação anátomo-clínica, as fissões anteriores à fissura Silviana correspondem às afasias não-fluentes, na qual acontece principalmente o prejuízo à expressão. As lesões posteriores à fissura Silviana dão origem às afasias fluentes, nas quais o maior prejuízo costuma ser a alteração da compreensão, e as lesões da região perisilviana provocam as afasias com prejuízo da repetição.

Segundo as autoras, a pesquisa das alterações da linguagem inclui o exame dos seguintes itens: 
- fala espontânea: avaliação da fluência

- compreensão oral e escrita: através da apresentação de material por entrada auditiva e visual com complexidade crescente.

- repetição/ leitura oral: também testadas em ordem crescente de complexidade

- nomeação: esta função está sempre alterada nas afasias, de forma mais ou menos grave. Os meios mais frequentes de avaliação são a nomeação por confrontação visual, ou seja, o indivíduo nomeia objetos que lhe são mostrados, e a nomeação responsiva, na qual o indivíduo nomeia o objeto com base na sua descrição funcional, feita pelo examinador.

- escrita: são avaliados a cópia, escrita sob ditado e expressão escrita.

- sintomas associados auxiliares para localização anatômica da lesão: hemiparesias (perda de movimento em um dos lados do corpo), hipoestesias (diminuição da sensibilidade térmica, tátil e dolorosa em uma região corporal), apraxias (perda da capacidade de executar movimentos precisos), hemianopsias (perda da visão do objeto abrangendo a metade dos campos visuais, ou apenas de um só quadrante) e agnosias (perda da capacidade de reconhecer objetos ou símbolos utilizando um dos cinco sentidos).

Ao lado dessa classificação clínica, outros tipos de conhecimento podem ser utilizados para os estudos das alterações de linguagem. A abordagem cognitiva enfatiza o sintoma na tentativa de estabelecer modelos de funcionamento mental normal a partir das perdas que ocorrem no indivíduo lesado. Na abordagem cognitiva não existe a preocupação de classificar o tipo de afasia do paciente, mas sim identificar o mecanismo referente ao sintoma.

Alterações da linguagem e prejuízo da capacidade de comunicação podem ocorrer em sujeitos nos quais o processamento linguístico básico não está muito afetado. Isso porque o processamento da linguagem se a poia em outras funções do cérebro, cuja integridade é necessária para um bom desempenho linguístico. Entre elas estão os mecanismos de atenção, a memória operacional e o sistema executivo central: 
- atenção: diz respeito à capacidade do sistema nervoso central de estabelecer um foco delimitado para onde direciona suas atividades perceptuais e de processamento.

- memória: memória é o termo utilizado para designar o processo mental que permite ao indivíduo guardar informação para recuperá-la mais tarde (Squire \& Butters, 1984), estando intimamente relacionada ao aprendizado. A formação da memória obedece a um mecanismo composto de várias etapas: registro da informação, estocagem de curto prazo (memória de curto prazo ou operacional), consolidação, estocagem de longo prazo e recuperação (lembrança).

- sistema executivo central: a área pré-frontal desempenha, entre outras coisas, a função de supervisionar a alocação dos recursos do sistema de atenção e da memória operacional. Isso é chamado de função executiva central.

A afasia compromete o desempenho do indivíduo na maior parte dos exames neuropsicológicos, já que a linguagem é uma das funções básicas necessárias para o desenvolvimento de habilidades intelectuais superiores. Grande parte do processo de pensamento se constrói a partir da internalização do discurso egocêntrico da criança no decorrer do seu amadurecimento (Joseph, 1982). Existem indícios de que distúrbios da linguagem podem comprometer, inclusive, tarefas sustentadas por estratégias perceptuais (Cohen et al., 1980). Além disso, boa parte dos testes requer entrada e raciocínio sobre o material apresentado verbalmente, no mínimo em forma de instruções para sua realização, quando não para a própria execução. Embora existam baterias de testes que privilegiam o trabalho sobre material não-verbal, os déficits de compreensão em especial tornam bastante limitada a possibilidade de execução e interpretação do exame neuropsicológico.

\subsection{Alterações da habilidade de nomeação}

Como mencionado anteriormente, em toda afasia existe um grau mais ou menos relevante de dificuldade para encontrar palavras. A capacidade de acessar os elementos lexicais é fundamental para a comunicação, uma vez que uma expressão verbal correta requer a seleção de significantes 
adequados ao que se quer enunciar. Ainda que o sujeito tenha dificuldade em produzir um discurso fluente, a capacidade de expressar nomes permite um alto nível de preservação de transmissão de informação (Peña-Casanova, 2005).

A anomia é um problema no acesso a palavras na produção do discurso escrito ou falado. Ainda que a dificuldade de encontrar palavras seja comum em indivíduos com desordens linguísticas, a anomia pode ocorrer mesmo na ausência de danos gerais à linguagem. Problemas para encontrar as palavras mais relevantes para o discurso fazem com que esse discurso seja algumas vezes vazio de significado ainda que seja gramatical e fluente (Ellis \& Young, 1996).

Em cada forma clássica de afasia existe um traço clínico característico, sendo que as parafasias semânticas são um fenômeno generalizado em maior ou menor intensidade. Aparentemente, os afásicos de Broca tendem a rejeitar tarefas desse tipo, os sujeitos anômicos apresentam a característica de não produzirem muitos erros fonêmicos, e os afásicos de Wernicke tendem a mostrar pouca melhora quando lhes são apresentados os primeiros sons da palavras a fim de ajudá-los a recuperar a palavras completa (Peña-Casanova, 2002). Esses fatos, juntamente com os traços semiológicos e topográficos das lesões, constituem a base da classificação das anomias.

Existem muitos casos em que os sujeitos apresentam bom rendimento nos testes de nomeação de imagens, mas cujo rendimento da linguagem espontânea apresenta transtornos devidos a uma grave dificuldade de encontrar as palavras. Segundo Peña-Casanova (2005) as diferenças entre os rendimentos da denominação (por confrontação visual) e da evocação de palavras durante a linguagem espontânea dependem de diversos fatores. Em alguns casos, os sujeitos são capazes de evocar parcialmente o material fonológico da palavra procurada, enquanto em outros casos destaca-se a produção da informação semântica parcial (referências ao uso, ao material ou ao contexto). Em outros casos, a semiologia é mista (fonológica e semântica), e como mencionamos anteriormente, a frequência da palavra solicitada também é relevante. Nettleton \& Lesser (1991) afirmam que certos afásicos fluentes têm dificuldade em restringir sua tarefa de nomeação à produção de somente um nome.

Em alguns casos de anomia, os pacientes conseguem reconhecer e repetir as palavras que anteriormente não conseguiram recuperar e, algumas vezes, eles apresentam uma boa noção do significado dessas palavras. Por exemplo, quando o sujeito EST (FludeAndrew et al., 1989) viu um conjunto 
de imagens de objetos (aos quais ele não conseguiu nomear) ele foi capaz de apontar a figura apropriada quando o nome lhe foi dito.

O prognóstico da anomia é relativamente favorável (Kertesz \& McCabe, 1977) sendo que cerca de metade dos casos de afasia anômica inicial são recuperados, mas em muitos casos o transtorno da evocação de palavras constitui um problema importante e uma sequela que afeta um bom nível final de recuperação dos pacientes, em alguns deles, a anomia é a única sequela definitiva da afasia. Depois dos seis primeiros meses de evolução a tendência é que haja uma estabilização, sendo observada uma melhora rápida depois dos dois primeiros meses, embora a recuperação possa ser mais lenta (Holland, 1989; Knopman e cols., 1984; Newcombe e cols., 1976).

A anomia é um fenômeno praticamente generalizado nos sujeitos afásicos. No entanto, um estudo detalhado das alterações lexicais faz com que seja possível reconhecer diferentes tipos de anomia e diversos aspectos específicos que são importantes para a recuperação desses sujeitos. 


\section{Capítulo 8}

\section{A afasia sob um ponto de vista linguístico}

De acordo com Jakobson, o primeiro intérprete da afasia, Hughlings Jackson, reconheceu que uma mutação afásica pode ser vista como um fenômeno de natureza dupla: quando um sujeito afásico diz "cadeira" no lugar de "mesa", ele apresenta primeiro um déficit na sua habilidade de produzir a palavra "mesa" e, em segundo, uma compensação através da produção da palavra "cadeira". Segundo o autor, para o estudo da linguagem essa observação é particularmente interessante, pois demonstra que a afasia pode levar à redistribuição de funções linguísticas. Essa afirmação é justificada pelo autor através da apresentação de exemplos encontrados em línguas como o russo e o tcheco, nas quais podemos ver que alguns fenômenos patológicos encontrados em sujeitos falantes de tcheco são correspondentes à linguagem padrão no russo (Jakobson, 1971).

Ainda segundo Jakobson, perdas e compensações da afasia põem em foco a interrelação dos elementos cognitivos e expressivos da linguagem, e a afasia provê um tópico vital para os estudos da linguagem. De acordo com ele, autores como Goldstein e Luria apontam a importância dos problemas linguísticos envolvidos no estudo da afasia; seus trabalhos sugerem que os linguistas não podem se abster da tomada de um papel mais ativo na investigação dos prejuízos linguísticos e na revisão de teorias anteriores.

Jakobson mantém seus argumentos sobre a necessidade de uma maior participação de linguistas nos estudos das afasias. Os linguistas devem prestar atenção, e realmente prestam, a problemas estatísticos da linguagem, e a linguística quantitativa é um dos aspectos importantes dessa 
ciência, mas para saber contar é preciso saber o que estamos contando. Seria inútil contarmos sem uma definição das características qualitativas, sem a definição das unidades e categorias a serem contadas.

Os resultados dos estudos puramente quantitativos sobre afasia não estão de acordo com os fatos linguísticos. Todas as "quase provas" usadas para substanciar esse viés são fúteis porque são baseadas em rubricas fictícias que ignoram as estruturas fonêmicas, morfológicas e sintáticas da linguagem (Jakobson, 1971).

Jakobson afirma que, primeiramente, os linguistas precisam se familiarizar com os termos técnicos e as ferramentas das disciplinas médicas que lidam com afasia. Depois disso, eles devem submeter os casos clínicos observáveis a uma análise linguística completa. Finalmente, devem trabalhar com sujeitos afásicos a fim de observar os casos diretamente e não apenas através de gravações preparadas que são concebidas e preparadas de formas diferentes.

Ainda segundo ele, existe um nível de fenômeno linguístico em que há convergência conceitual de grande parte dos autores: a análise da desintegração dos padrões sonoros. Se observarmos que na aquisição de linguagem de uma criança um certo fenômeno B implica na aquisição de um certo fenômeno $\mathrm{A}$, nós descobriremos que na afasia a perda de A implica na perda de $B$, enquanto a reabilitação de um afásico caminharia na mesma direção da aquisição da criança: a reaquisição de B implica a presença renovada de A. Segundo Jakobson, existe a chance de que esse mesmo padrão possa ser encontrado também nas questões envolvendo problemas gramaticais, mas não muitos esforços foram concentrados nessa direção.

O ponto principal do artigo de Jakobson é de natureza diferente, contudo, e de grande importância tanto para o estudo da afasia como para a ciência da linguagem, especialmente para a análise da estrutura, do comportamento verbal e da arte verbal (a literatura): a metáfora.

Os conceitos de metáfora e metonímia apresentariam a expressão mais condensada de dois modos básicos de relação: a relação interna de similaridade (e contraste) é o que encontramos por detrás da metáfora; a relação externa de contiguidade (e afastamento) determinam a metonímia.

Em vários aspectos, a linguagem lida com ambos os modos de relação. Os componentes de qualquer mensagem estão necessariamente ligados com o código linguístico através de um relação interna de equivalência (sem a qual dois falantes não poderiam compreender um ao outro) e com o contexto através de uma ligação externa de contiguidade (sem o qual a 
mensagem pode não ser completamente entendida).

Quando falamos da hierarquia fonema, morfema, palavra, sentença, proposição, devemos saber que essa organização não é a penas uma escala quantitativa. Essa classificação é feita com base em questões qualitativamente e estruturalmente diferentes. Cada nível de unidade linguística apresenta uma relação diferente entre código e contexto e essas diferenças geram grandes consequências para os vários problemas de estrutura linguística e para o estudo da afasia. Uma vez que a afasia é primeiramente um enfraquecimento da linguagem, nenhum diagnóstico pode ser feito sem o exame linguístico competente do que foi prejudicado na linguagem de um sujeito. Em particular, como ele opera o código e o contexto linguístico? Como trata unidades linguísticas de níveis diferentes? A classificação linguística dos diferentes casos deve ser baseada nesses sintomas verbais dos quais poderemos deduzir a síndrome com mais propriedade.

Na tentativa de estabelecer uma classificação puramente linguística para os prejuízos causados pela afasia, Jakobson apresenta a seguinte questão: quais categorias de signos verbais, e de signos em geral, são afetados em cada caso de afasia? Segundo ele, os linguistas podem apenas concordar que a patologia da linguagem está longe de ser um distúrbio aleatório, e que, ao contrário, obedece a um conjunto de regras, e que as regras por detrás da regressão da linguagem não podem ser estabelecidas sem o uso consistente de técnicas e metodologias linguísticas. Os transtornos de linguagem apresentam suas próprias ordens e requerem uma comparação sistemática com o nosso código verbal normal (Jakobson, 1973).

\subsection{Determinação das afasias}

A ocorrência frequente de tipos de afasia puramente polares não pode ser negada; existem dicotomias fundamentais que nos permitem classificar os prejuízos afásicos. Dois fatores diferentes, seleção e combinação, têm papel essencial em qualquer evento de discurso. As entidades dentre as quais fazemos nossas seleções são mutuamente conectadas por várias formas e graus de similaridade em todas as suas variedades: semelhança, equivalência, analogia, parecença, diversos graus de especificação, contraste. Ao contrário da seleção, que é baseada numa relação interna, a combinação envolve a relação externa de contiguidade nas suas várias formas e graus: proximidade, afastamento, subordinação e coordenação. 
Segundo o autor, parece óbvio que existem dois tipos básicos de afasia, pois ou a relação interna de similaridade - e a correspondente habilidade seletiva está prejudicada —, ou, ao contrário, a relação externa de contiguidade - e, portanto, a capacidade de combinação - é que parece estar afetada. As diferenças entre os transtornos de combinação e seleção coincidem com os distúrbios de codificação e decodificação.

É claro que em cada caso nem todos os sintomas precisam estar presentes e nem todos os níveis linguísticos precisam necessariamente estar afetados. Em alguns casos, o déficit é mormente ou somente fonológico; em algumas instâncias, as perdas pertencem principalmente ou apenas ao nível sintático.

No estudo da patologia do discurso, uma teoria que se diferencia da realidade linguística é a hipótese de que os danos causados pela afasia podem ser vistos como um transtorno unitário geral, sendo que os tipos variados de afasia representariam uma diferença na quantidade de perturbações, e não na qualidade das mesmas. Segundo Jakobson, qualquer linguista que teve a oportunidade de observar diferentes casos de discurso afásico teria de concordar com os neurologistas, psiquiatras e psicólogos que acreditam na diversidade qualitativa dos padrões de afasia. Uma análise linguística desses padrões leva à averiguação de síndromes integrais e distintas, bem como à sua tipologia estrutural.

A seguir, apresentaremos os tipos de afasia definidos linguisticamente por Jakobson, apoiados pelos dados de Luria.

\subsection{Primeira dicotomia: transtorno de codifica- ção (combinação / contiguidade) em oposi- ção ao transtorno de decodificação (seleção ( similaridade)}

Duas operações fundamentais estão por detrás do nosso comportamento verbal: seleção e combinação, sendo que a seleção é baseada na similaridade e a combinação na contiguidade. A tentativa de Jakobson de aplicar essa característica da linguagem aos estudos da afasia (chamados de transtorno de similaridade, ligado à decodificação, e transtorno de contiguidade, ligado à codificação) (Jakobson \& Halle, 1956) foi encorajada pela resposta 
positiva de especialistas no diagnóstico e tratamento das afasias, sendo que essas duas qualidades de afasia seriam similares ao conhecidos transtornos sensorial e motor.

Os termos "codificação" e "decodificação" indicam os tipos de danos causados pela afasia. Eles podem ser utilizados com um apêndice opcional: transtorno "predominantemente na codificação" e "predominantemente na decodificação", já que o enfraquecimento de um processo geralmente afeta também o outro.

A tradicional afasia de Broca (chamada também de eferente) é oposta à afasia de Wernicke (também chamada de sensorial), sendo a primeira o caso mais típico de distúrbio de contiguidade e a segunda o caso mais notável de distúrbio de similaridade.

A combinação fica prejudicada na afasia eferente. No nível fonêmico isso significa que o sujeito encontrará problemas para utilizar grupos fonêmicos, construir sílabas e fazer a transição de um fonema para o outro e de uma sílaba para outra. No nível das unidades com significado, a deficiência é primeiramente gramatical (agramatismo) no tipo eferente, e lexical no tipo sensorial. Portanto, os conectivos, os artigos e os pronomes, que servem para fortalecer o contexto gramatical, permanecem intactos no transtorno sensorial, mas são os primeiros a serem perdidos no transtorno eferente. A relação sintática é dependente, e assim sendo, no agramatismo todos os tipos de palavras dependentes são perdidas.

$\mathrm{Na}$ afasia eferente "a abolição de predicados, que evidentemente apresenta a perda do poder de elocução" (Jackson \& Taylor, 1958) é apenas a expressão focal de uma tendência geral de abolir qualquer categoria sintática. Dentre os dois tipos de dependência sintática, regência e concordância, o último é de algum modo mais resistente do que o primeiro no transtorno de contiguidade da afasia eferente, porque a concordância é uma dependência sequencial que envolve similaridade gramatical, enquanto a regência é construída em mera contiguidade. Em última análise, o discurso é reduzido a palavras primárias e independentes - substantivos e formas nominais de verbos. O sujeito não conseguiria operar com contiguidade, mas operações baseadas na similaridade permaneceriam intactas. Portanto, ele perderia a habilidade de proposicionar, e o contexto se desintegraria. Primeiro, as palavras relacionais seriam omitidas, fazendo surgir o chamado "estilo telegráfico". Quanto mais uma palavra for sintaticamente independente, mais forte será a tenacidade no discurso dos afásicos com transtorno de contiguidade. 
Uma vez que a hierarquia das unidades linguísticas é a superposição de contextos maiores, o transtorno de contiguidade destrói essa hierarquia, já que ela afeta a construção de contextos. Por um lado, a palavra deixa de servir como constituente de contextos maiores e, de outro, ela se torna indissociável dos seus componentes gramaticais, o que promoveria o declínio da variação inflexional - conjugação e declinação. Esse déficit, juntamente com a perda de palavras relacionais e do padrão sintático, é um sintoma típico do agramatismo. Esses afásicos, para quem a palavra é a unidade derradeira, são incapazes de entender, discernir ou repetir exemplos de palavras que não lhes sejam familiares.

$\mathrm{Na}$ afasia sensorial, ao contrário, o sujeito gramatical, que é a única parte independente de contexto da sentença, pode ser perdido, já que o estímulo principal do sujeito está na seleção e não na combinação. O sujeito é o núcleo da construção sintática e, em algumas línguas, o sujeito marca obrigatoriamente o começo da sentença. Um empobrecimento da variedade de substantivos, uma tendência a utilizar substitutos gerais e pronominalizados, e uma inabilidade para encontrar sinônimos e antônimos são os sintomas do transtorno de similaridade. Esse transtorno pode causar problemas no acesso a palavras ou a fonemas.

Sujeitos com relações internas prejudicadas (desordem de similaridade) e relações externas intactas são capazes de seguir e completar um contexto. Como a atenção desse sujeito estaria totalmente voltada para a construção do contexto, frequentemente ele exibirá habilidade em completar uma palavra fragmentada ou a parte de uma sentença que lhe seja apresentada. Afásicos com a relação interna prejudicada têm dificuldade em organizar unidades do código de acordo com a sua similaridade. Eles são capazes de combinar duas unidades dentro da mensagem, mas não de substituir uma unidade por outra com base em semelhança mútua (ou contraste). Esses sujeitos teriam perdido o poder de fazer a equação entre duas palavras correspondentes de dois códigos diferentes (heteronímia), ou palavras semanticamente similares do mesmo código (sinônimos), ou entre uma palavra e um sintagma mais explícito (circumlocução). Qualquer habilidade de tradução estaria perdida para esses sujeitos e, se forem bilíngues, a capacidade de trocar de um código para outro se perderia igualmente, além da capacidade de translação intersemiótica (como a transposição de um sistema de signos para outro). Portanto, o sujeito encontraria dificuldades na nomeação de um objeto mostrado a ele numa figura, ou apontado pelo examinador. Como sua atenção estará voltada para a contiguidade, a 
tarefa de repetir palavras é uma tarefa impossível. Das duas variedades de discurso figurativo - metáfora, baseada na similaridade, e metonímia, fundada na contiguidade - apenas a última é usada e compreendida.

Jakobson aponta que, segundo Goldstein, essa perda de associação por similaridade pode ser denominada como perda de "atitude abstrata", o que parece ao autor questionável. Os passos metáforico e metonímico são dois tipos diferentes do que ele chama de "comportamento abstrato". Talvez essa noção seja muito vaga na análise e classificação das afasias. Devemos lembrar que a maioria das palavras abstratas do nosso vocabulário, como conjunções, preposições, pronomes e artigos são as partes de discurso mais bem preservadas e as mais frequentemente usadas no discurso desse tipo de afásico. Se esses índices de relação são mantidos nesse tipo de afasia, isso se deve à sua função primária de prover o tecido conectivo do contexto.

A oposição desses dois tipos de comportamento verbal - o metonímico, preocupado com as relações externas e o metafórico, envolvido com as relações internas - está por trás dos distúrbios afásicos dos transtornos de similaridade e de contiguidade. Enquanto cada um desses dois tipos de afasia tende à unipolaridade, o comportamento verbal normal é bipolar. Contudo, qualquer uso individual da linguagem, qualquer estilo verbal, qualquer tendência em qualquer arte verbal exibe uma clara predileção ou para o dispositivo metafórico, ou para o metonímico.

Podemos nos perguntar por que o contexto estaria prejudicado no transtorno de codificação e não no transtorno de decodificação, e por que, por outro lado, esses constituentes autônomos que estão intactos no transtorno de codificação, estão perdidos no transtorno de decodificação. A resposta, segundo Jakobson, está no fato de que os processos de codificação e decodificação apresentam uma diferença crucial na ordenação. A codificação começa com a seleção de constituentes que devem ser combinados e integrados em um contexto. A seleção é o antecedente, enquanto a seleção do contexto é a consequência ou o alvo do codificador. Para o decodificador, essa ordem é inversa. Primeiro o decodificador encontra o contexto, em segundo, ele deve detectar os constituentes; a combinação é o antecedente, a seleção é a consequência, o alvo derradeiro do processo de decodificação. O codificador começa com uma operação analítica que é seguida pela síntese; o decodificador recebe a informação sintetizada e começa sua análise. $\mathrm{Na}$ afasia a consequência é a prejudicada, enquanto o antecedente se mantém intacto; a combinação, portanto, é deficiente na afasia quando há problemas de codificação, e a seleção é deficiente quando há problemas na 
Segunda dicotomia

decodificação.

Baseando-se nisso, o autor afirma que a metáfora é alheia ao transtorno de similaridade e a metonímia ao transtorno de contiguidade.

\subsection{Segunda dicotomia: limitação em oposição à desintegração}

Dos dois tipos básicos de afasia — eferente e sensorial — o autor passa para outros quatro tipos que são discutidos por Luria em sua monografia. Aqui nós encontramos duas formas atenuadas: dentre os tipos de afasia gerados pelo transtorno de codificação existe o que Luria chama de afasia dinâmica, e dentre os transtornos de decodificação, a chamada afasia semântica (apud Luria (1962)). Os transtornos dinâmicos afetam apenas as unidades de discurso que vão além dos limites da sentença, ou seja, proposições extensas, especialmente monólogos. Em outras palavras, esse prejuízo toca apenas aquelas combinações verbais que execedem as barreiras do código verbal, já que a combinação de palavras e grupos de palavras dentro de uma sentença é a maior construção inteiramente organizada na base de regras gramaticais compulsórias.

Outra variante da mesma síndrome foi descrita por Luria, ele a define como a "dissolução da função regulativa do discurso". Vista em seu aspecto linguístico, esse sintoma pode ser interpretado como uma inabilidade de transpor um diálogo verbal em um sistema de signos artificiais, ou levar adiante um diálogo combinando proposições verbais com proposições transpostas para esse outro sistema.

O discurso das afasias dinâmica e semântica é caracterizado por dois aspectos opostos: o primeiro é marcado por uma excessiva encorporação no código, e o segundo por uma encorporação com um único foco no contexto. A linguagem normal faz distinção entre classes de palavras e funções sintáticas, uma mesma classe pode realizar diferentes funções na sentença, enquanto uma função pode ser realizada por diferentes classes de palavras. A afasia semântica tende a descartar esse dualismo e a estabelecer uma única função específica à cada classe de palavra. Sob essas condições, cada classe de palavra é definida pelo local que seus membros ocupam em uma sequência sintática, e a variedade desses locais está sujeito a restrições (por exemplo, uma sequência do tipo "father's brother" será mal compreendida). 
Terceira dicotomia

A afasia semântica simplifica e comprime as regras sintáticas; além disso, ela apaga a conexão gramatical entre sentenças, isso pode ser observado mesmo após a reabilitação do sujeito. Um exemplo dessa condição é que a regulação de pronomes anafóricos e artigos pode se perder, o autor cita um paciente que, já recuperado de um transtorno semântico, cometeu um lapso sintomático: "a minha esposa não está aqui hoje. Ele não veio comigo"

\subsection{Terceira dicotomia: sequência (suscetividade) em oposição à co-ocorrência (simultaneidade)}

A descrição e classificação dos prejuízos linguísticos causados pela afasia sempre esbarram na pergunta sobre se um conjunto de entidades linguísticas está afetado simultânea ou sequencialmente. A dicotomia de sequência e co-ocorrência faz um corte através da divisão fundamental de prejuízo de codificação (combinação) e decodificação (seleção).

Vimos que desses dois modos de organização que operam a linguagem, é a combinação que sofre nos transtornos de codificação. Existem duas variedades de combinação na linguagem: co-ocorrência e sequência temporal; desses dois, a sequência é aquela que está por trás do prejuízo nos casos de afasia eferente e dinâmica dentro dos transtornos de codificação, enquanto o terceiro tipo, afasia aferente, apresenta enfraquecimento na co-ocorrência. No nível fonêmico, a afasia eferente causa danos na concatenação sequencial de fonemas, enquanto na afasia aferente, a combinação de fonemas com características distintivas co-ocorrentes é perdida.

O sintoma mais típico de afasia aferente é a ampla variedade de flutuações na implementação de fonemas, nesses casos, apenas certos constituentes da sequência sobrevivem e seu contexto fica deteriorado, do mesmo modo, a afasia aferente preserva apenas constituentes únicos do feixe simultâneo, sendo que o resto do contexto é preenchido quase aleatoriamente. A afasia sensorial, orientada na direção do contexto, causa a perda de constituentes avulsos, ou seja, apenas traços separados do fonema; aparentemente, os traços que se perdem são aqueles que são menos dependentes do ambiente simultâneo e sequencial. Em contraste, a afasia aferente parece preservar apenas os traços que são dependentes do ambiente e que estão por trás do padrão fonêmico da linguagem. Enfim, a afasia aferente é um transtorno de codificação em combinação simultânea. 
Já a afasia amnéstica ou acústico-amnéstica, como é chamada por Luria (1962), é um transtorno de decodificação na seleção sequencial. Enquanto a afasia sensorial afeta a identificação de constituentes que dizem respeito a um grupo de possibilidades substitutivas co-ocorrentes, a afasia amnéstica prejudica essa identificação apenas se um dado constituente for membro de um par coordenativo (ou séries maiores) de palavras (ou orações). A afasia amnéstica é um transtorno de similaridade que envolve a única sequência gramatical baseada em pura similaridade, e a afasia aferente é um transtorno de contiguidade que envolve o único alinhamento de constituentes co-ocorrentes na sequência de som da linguagem. A contiguidade de duas dimensões (sequencial e co-ocorrente) dos traços distintivos confunde o codificador que sofre de afasia aferente, enquanto a similaridade de duas dimensões (paradigmática e sintagmática) de palavras ou orações paratácticas confunde o decodificador que sofre de afasia amnéstica.

\subsection{Conclusão}

Esses comentários de Jakobson visam, por um lado, a especificação dos sintomas verbais que distinguem os seis tipos de afasia apresentados por Luria (1962), por outro lado, visam retraçar a interrelação desses tipos de afasia de um ponto de vista estritamente linguístico.

Os três tipos de afasia chamados de eferente, dinâmica e aferente são caracterizados pela sua deficiência quanto à contiguidade, com a deterioração do contexto. Os outros três tipos, sensorial, semântica e amnéstica, apresentam distúrbios de similaridade, que danificam o código. Os mesmos dois grupos são diferenciados entre si como transtornos de codificação e decodificação.

Nos três tipos classificados como transtornos de contiguidade, a habilidade de combinar e integrar está enfraquecida, no entanto, nos tipos eferente e dinâmico esse prejuízo afeta a integração de constituentes sucessivos, enquanto no tipo aferente, os constituentes co-ocorrentes são os que falham em serem integrados.

Nos três tipos de distúrbios de similaridade, a habilidade de selecionar e identificar está afetada, contudo, nos tipos sensorial e semântica o que sofre é simplesmente a escolha dentre possibilidades co-ocorrentes e a identificação de tais constituentes alternativos, enquanto na afasia amnéstica existem impedimentos na escolha e identificação apenas no que diz respeito a cons- 
tituentes adjuntos em um grupo coordenativo. Portanto, apesar dos tipos simples de transtornos de contiguidade que envolvem apenas o conjunto de suscetividade, e dos tipos simples de transtornos de similaridade que envolvem apenas o conjunto de simultaneidade, encontramos aqui dois tipos complexos e intermediários de afasia: um transtorno de contiguidade baseado no eixo da simultaneidade (afasia aferente), e um transtorno de similaridade dependente do eixo da suscetividade (afasia amnéstica).

Em distinção à afasia eferente, a afasia dinâmica não prejudica o contexto gramatical ou o fonêmico, apenas os contextos verbais que contêm mais de uma sentença e portanto excedem os limites da integridade sintática.

Por outro lado, a afasia semântica elimina qualquer diferença entre categorias morfológicas e suas funções sintáticas. Incidentalmente, essa perda de delimitação parace favorecer os neologismos. A intensa produção de neologismos entre afásicos e crianças é devida à falta de discriminação entre dois níveis verbais: as palavras e sentenças prontas, prontas apenas no padrão gramatical, mas relativamente livres na construção lexical.

$\mathrm{O}$ autor relembra que a afasia dinâmica pertence aos tipos de distúrbios que são focados no código e prejudicados no que diz respeito ao contexto; e que a afasia semântica faz parte do grupo de distúrbios que têm o foco no contexto e prejuízo no código. Assim, a afasia dinâmica afeta apenas contextos não-codificados, enquanto a afasia semântica tende a restringir o código gramatical através da limitação da autonomia das categorias morfológicas dando preferência à sintaxe. Os tipos dinâmico e semântico das afasias são distintos dos tipos eferente e sensorial respectivamente. Sendo os dois primeiros limitativos, e o segundo par disruptivo. Essa terceira dicotomia - limitação em oposição à desintegração - envolve apenas as variedades simples das afasias de codificação e decodificação, mas não se aplica aos tipos mais complexos e transicionais.

Nessa tentativa de Jakobson de apresentar os diferentes tipos de afasia, bem como seus sintomas verbais correspondentes, o autor se restringiu a critérios linguísticos, porém, ele afirma que uma delimitação rigorosa de níveis não impede que tentemos traçar uma correspondência entre eles. $\mathrm{Ou}$ seja, entre os afetos da linguagem e seu substrato anatômico.

A conexão entre as lesões mais anteriores do córtex e o enfraquecimento da codificação, bem como a conexão entre as lesões mais posteriores e o enfraquecimento da decodificação, são, segundo o autor, amplamente reconhecidos. É também importante percebermos que os prejuízos na codi- 
ficação de sequências correspondem a lesões anteriores fronto-temporais e frontais (Luria, 1958), enquanto os prejuízos de decodificação, que envolvem co-ocorrência, o eixo de simultaneidade da linguagem, estão conectados a lesões pós-temporais e pós- parietais. Os tipos transicionais, que conectam prejuízos de codificação com o eixo de simultaneidade ou prejuízos de decodificação com o eixo de suscetividade da linguagem, aparentemente correspondem a lesões nas áreas retrocentral e centro-temporal (apud Luria, 1947; Penfield e Roberts, 1959).

Lesões fronto-temporais e pós-temporais são responáveis pelos tipos básicos de danos na codificação e na decodificação, e em contradistinção a essas duas formas de afasia que são desruptivas, estão os tipos limitativos que estão conectados a duas áreas polares: a desordem dinâmica é ligada às porções anterior e frontal do cérebro ( $a p u d$ Luria, 1962), e a desordem semântica está ligada às seções póstero-parietal e parieto-occipital (apud Luria, 1958; Pribram, 1960).

Segundo Jakobson, o estudo da afasia não pode mais ignorar o fato de que uma tipologia intrinsicamente linguística de prejuízos afásicos, delineada sem qualquer consideração aos dados anatômicos, permite um padrão simétrico e coerente de relação, que se prova notoriamente próximo à topografia dessas lesões cerebrais que estão por trás desses prejuízos. 


\section{Capítulo 9}

\section{As entrevistas}

Para a realização desta pesquisa procuramos considerar as diferentes teorias apresentadas até aqui. Nas análises apresentadas nos capítulos a seguir levamos em conta a produção e compreensão linguística dos sujeitos tanto nos momentos em que eles deveriam responder a perguntas guiadas, quanto nos momentos de conversa espontânea entre a entrevistadora e os entrevistados.

Na tentativa de provar a hipótese apresentada no capítulo 1 , ou seja, que poderia haver diferenças entre a produção e compreensão de um mesmo nome utilizado ora em sentido literal ora em sentido metafórico, o teste descrito no capítulo introdutório foi remodelado, utilizando nomes de animais em situação literal e não-literal, a fim de observarmos o comportamento linguístico de sujeitos com dificuldade de nomeação e suas respectivas habilidades para recuperar esses itens lexicais. As etapas a serem seguidas estão descritas a seguir.

\subsection{Primeira etapa}

Para a realização da primeira parte do teste, elaboramos uma lista com dez nomes de animais que podem ser utilizados como metáforas, parecida com aquela a que nos referimos no capítulo 1 . Os nomes utilizados para o presente teste são: elefante, baleia, gato, touro, girafa, cavalo, cobra, porco, burro, e tartaruga. Antes de aplicarmos o teste de metáforas é preciso estabelecer se os sujeitos apresentam dificuldade na categoria "nomes de animais". Para tanto, o primeiro passo é verificar se os pacientes afásicos 
são capazes de nomear esses animais e/ou de reconhecê-los quando os nomes são apresentados.

Em anexo encontram-se dez figuras de animais desenvolvidas com o propósito de testar a habilidade de nomeação e reconhecimento pelos sujeitos ${ }^{1}$. A primeira parte do teste, portanto, consiste simplesmente na apresentação dessas figuras, às quais o sujeito entrevistado deverá nomear. Nos casos em que o paciente não foi capaz de nomeá-las, as figuras foram apresentadas em conjunto e o nome de um animal foi dado (um de cada vez) e o paciente teve de apontar no conjunto de figuras aquela que corresponderia ao nome solicitado. Com esse primeiro teste, esperamos estabelecer se:

1. o paciente tem dificuldade para nomear animais

2. o paciente consegue reconhecer os animais quando os nomes lhe são apresentados

No teste mencionado no capítulo 1 pudemos observar que o paciente foi capaz de reconhecer os animais quando o nome lhe foi dado, mas não foi capaz de nomeá-los sozinho, mostrando que as habilidades de produção e compreensão são diferenciadas e, portanto, devem ser testadas separadamente nos demais sujeitos.

\subsection{Segunda etapa}

Todos os sujeitos apresentaram alguma dificuldade na realização da primeira etapa. Portanto, todos prosseguiram para a segunda parte do teste que consiste em estabelecer se os pacientes, apesar de não serem capazes de nomear os animais, são capazes de reconhecer e enunciar os seus respectivos traços semânticos. Assim, os pacientes foram questionados sobre as características dos dez animais mencionados. A princípio, dessa vez os sujeitos não deveriam ter ajuda visual (o paciente não poderia ver as figuras). Dois dos sujeitos, contudo, não conseguiram realizar esta tarefa sem observar as figuras.

\footnotetext{
${ }^{1}$ Figuras feitas por Isabelle Seixas Lima
} 


\subsection{Terceira etapa}

Depois de termos estabelecido a dificuldade dos sujeitos para nomear e reconhecer nomes de animais, pudemos testar suas habilidades de produção e compreensão das metáforas. A terceira parte do teste, portanto, consiste em verificar a habilidade dos pacientes afásicos de produzir os nomes de animais em contexto de uso não-literal.

Nesta etapa, a entrevistadora enunciou para os pacientes uma sentença como "O João é muito gordo" e pediu a eles que fizessem a partir dela uma metáfora utilizando os nomes de animais apresentados anteriormente.

\subsection{Quarta etapa}

Nesta quarta e última etapa, a intenção foi determinar a habilidade dos sujeitos para entender os nomes de animais quando utilizados em contexto não-literal. Ao contrário da terceira etapa, ao invés de dizer os nomes dos animais, os sujeitos tiveram que ouvir frases do tipo "O João é um elefante" e foi pedido a eles que explicassem o que essa metáfora quer dizer.

A princípio, os sujeitos deveriam fazer a metáfora sozinhos, mas em alguns casos isso não foi possível. Nesses casos, a entrevistadora deu a eles três opções de significado e ele tiveram que escolher dentre essas opções qual se encaixaria melhor em cada situação. Assim, o teste foi apresentado da seguinte forma:

1. "O João é um elefante" quer dizer que o João é:

- gordo

- desleixado

- invejoso

2. “O João é um cavalo" quer dizer que o João é:

- invejoso

- grosseiro

- feio

3. "O João é uma gato" quer dizer que o João é: 
- bonito

- rico

- honesto

4. “O João é um touro" quer dizer que o João é:

- engraçado

- alegre

- forte

5. "A Maria é uma girafa" quer dizer que a Maria é:

- feia

- alta

- suja

6. “A Maria é uma cobra" quer dizer que a Maria é:

- pobre

- desorganizada

- maldosa

7. “O João é um burro" quer dizer que o João é:

- ciumento

- gordo

- pouco inteligente

8. “A Maria é uma baleia" quer dizer que a Maria é:

- gorda

- perigosa

- maldosa

9. “O João é um porco" quer dizer que o João é: 
- covarde

- pobre

- sujo

10. "A Maria é uma tartaruga" quer dizer que a Maria é:

- pouco inteligente

- pobre

- lenta 


\section{Capítulo 10}

\section{Apresentação dos sujeitos e análise dos dados}

Levando em consideração a tipologia das afasias apresentada por Jakobson, apresentaremos a seguir a análise feita para essa dissertação sobre os dados obtidos das entrevistas feitas com os sujeitos afásicos, mas primeiro teremos uma breve apresentação dos sujeitos e seus históricos, fornecida pelo Centro de Convivência de Afásicos da Unicamp.

\subsection{Os sujeitos}

\subsubsection{Sujeito: AA}

- Nascimento: Não consta

- Escolaridade: Não consta

- Resumo: Consta no relatório que o sujeito tem 40 anos, é solteiro, pedreiro aposentado e voltou a fazer alguns "bicos" em 2010 . O sujeito sofreu AVC em junho de 1997, com lesão têmporo-parietal esquerda e outro AVC em dezembro de 1997, com lesão têmporo-parietal direita. Em 2000 consta no laudo também um AVC isquêmico. Quanto aos danos físicos, encontramos em seu prontuário que ele apresenta lacunas com atresia do córtex na insula esquerda, giro frontal inferior, giro temporal superior, núcleos lentiformes e substância branca profunda parietal direita; focos hipointensos no fluir (glicose) também 
são vistos na substância branca subcortical parietal bilateralmente e nas regiões periventriculares; há um alargamento assimétrico dos ventrículos laterais mais acentuado à esquerda; alargamento dos sulcos corticais, cerebrais mais acentuados á esquerda; Hemisfério direito com multi-infartos cerebrais; Redução do número de ramos temporo parietais da artéria cerebral média esquerda; Não há fluxo discernível na artéria vertebral esquerda.

Esse sujeito apresenta diversos prejuízos linguísticos, além de uma exuberante apraxia de fala que prejudica fortemente sua comunicação. $\mathrm{O}$ indivíduo apresenta dificuldade de acesso lexical, dificuldade para formar sentenças completas e para articulação fonológica perfeita. A compreensão parece estar bem, assim como sua memória. Quanto aos problemas de acesso lexical, podemos observar dificuldade de a articulação e a transformação de conceitos em palavras.

$\mathrm{Na}$ primeira parte da entrevista, na qual foi pedido aos sujeitos que nomeassem figuras de animais, observamos que o sujeito reconheceu a maioria dos animais apresentados, sendo que em apenas duas figuras não houve nenhuma resposta de sua parte, e em uma delas ele não foi capaz de nomear o animal, mas deu a entender que sabia do que se tratava (ver "baleia" nos exemplos abaixo). Dado que a articulação das palavras é um dos mais notáveis prejuízos da sua habilidade linguística, consideramos que o sujeito conseguiu identificar e nomear os animais ainda que os nomes tenham sido produzidos com fenômenos na sua pronúncia. Vejamos o recorte a seguir:

Ent. AA, é o seguinte, eu tô estudando como é que vocês conseguem lembrar os nomes dos animais. Então a gente vai ver se você consegue lembrar os nomes dos animais. Se você não conseguir lembrar, não tem problema, depois eu vou mostrar as fotos pra você, aí eu vou falar os nomes e você vai tentar apontar pra mim. Aí isso é mais fácil né? Então tá bom. Muito bem. AA, esse aqui é o primeiro animal.

AA (incompreensível) Gi á. Giá.

Ent. Muito bem, girafa, exatamente. Esse aqui? (mostra a figura de uma baleia)

AA Da má. Do má. 
Ent. Do mar, isso. Tá certo. E esse aqui.(mostra a figura de um cavalo)

AA Cava. Cava.

Ent. Cavalo. Muito bem, esse daqui?(mostra a figura de um elefante)

AA (não há resposta)

Ent. Não? Elefante, isso, tá certo. E esse daqui? (mostra a figura de um gato)

AA Gatin. Gatin.

Ent. Um gatinho, muito bem. E esse daqui? Não? Não? Tudo bem. E esse? (mostra a figura de uma cobra)

AA Co - ba. Coba.

Ent. Cobra, ótimo. E esse? (mostra a figura de um touro)

AA Boi o.

Ent. Ótimo, muito bem. E essa? (mostra a figura de uma tartaruga)

AA (Não há resposta)

Ent. Não? Tudo bem, vou pular. E esse daqui? (mostra a figura de um burro)

AA É o $b u-o . B u$.

Ent. Burro, ótimo.

Como podemos ver, apesar da dificuldade para pronunciar as palavras, o sujeito foi capaz de nomear os animais em questão relativamente bem. No entanto, quando lhe foi pedido que descrevesse os animais mencionados, suas dificuldades ficaram mais evidentes. $\mathrm{O}$ sujeito demonstrou através de gestos as características que queria utilizar para a descrição, mas poucas palavras foram efetivamente enunciadas, como vemos a seguir: 
Ent. Burro, ótimo. Muito bem, AA, agora olha só, eu vou te perguntar desses animais e aí ce só me diz assim, se você conseguir, eu quero que você me diga uma palavra sobre eles. Por exemplo, se eu falar pra você como que é uma girafa? Cê consegue pensar alguma coisa que ela é? Alguma qualidade dela, alguma característica?

AA (Sujeito faz que não)

Ent. Não? E se eu mostrar, ajuda?

AA Boni... boni.

Ent. É isso? E se eu perguntar pra você como é uma baleia, cê consegue me falar? Como que é uma baleia? Não? Se eu mostrar, ajuda?

AA É... ma... boni.

Ent. Tá. Se eu perguntar como é um cavalo?

AA (faz gestos como se montasse um cavalo)

Ent. Isso, dá pra montar nele? Isso. Lembra mais alguma coisa se eu mostrar a foto?

AA (incompreensível)

Ent. Que monta, né? Tá bom, se eu perguntar como é um elefante.

AA É muito pesa.

Ent. Muito pesado. Isso, ótimo, muito bem. Se eu perguntar como que é um gato?

AA (faz gestos como se subisse uma parede)

Ent. Sobe as paredes? Isso, muito bem. Se eu perguntar como que é um touro?

AA (Não há resposta)

Ent. Não?

AA (faz gestos como se tivesse chifres) 
Ent. Tem chifre, chifra as pessoas?

AA (incompreensível)

Ent. Ele tem chifre, corre atrás das pessoas, dá chifrada, né? Isso.

AA (incompreensível)

Ent. Isso, entendi, tá ótimo. Se eu perguntar pra você como que é uma cobra?

AA (faz gestos)

Ent. Comprida?

AA (incompreensível)

Ent. Ah, ela morde? Entendi, entendi, muito bem. Se eu perguntar pra você como que é um porco?

AA (Não há resposta)

Ent. Não. Se eu mostrar a foto?

AA É. (incompreensível) (faz gestos de garfo e faca)

Ent. Você come? Muito bem. Como é que é uma tartaruga? Não?

AA (faz gestos)

Ent. Devagarinho? Ela é devagar, ela é lenta?

AA Deva-ga.

Ent. Devagar, muito bem. E último, como é que é um burro?

AA Bu-lo. Bu-lo.

Ent. Brilha?

AA (faz gestos de montar num burro)

Ent. Dá pra montar no burro também, é isso?

AA É. Pu-la. (faz gestos como se se prendesse alguma coisa no burro)

Ent. Ah, ele.. ele puxa o arado, trabalha? 


\subsubsection{Sujeito: AC}

- Nascimento: 8/08/1936

- Escolaridade: 1a. série do ensino fundamental

- Resumo: Em consulta com uma fonoaudióloga, sua afasia foi caracterizada como "anômica". Nas atividades do CCA, foi determinado que realmente se trata de uma afasia fluente, com dificuldades para encontrar palavras, não muito severa. AC desenvolveu estratégias para driblar esta dificuldade e demonstra não se incomodar muito com isso. De acordo com o relatório fornecido pelo CCA, o sujeito apresenta especial dificuldade com nomes próprios.

Durante a entrevista, o sujeito apresentou um discurso fluente, sem problemas de agramatismo ou fenômenos fonológicos. As características mais marcantes do seu discurso foram a dificuldade de acesso lexical, o uso de parafasias e perseveração.

Quanto às parafasias, observemos os recortes a seguir:

\section{Girafa}

Ent. Como tá a sua lembrança de nome. (mostra a figura de uma girafa)

AC Chô ver se o, chô ver se eu lembro. Essa daí é a zebra né?

Ent. É a zebra? Hum hum.

AC Não não, zebra não. Não tô falando procê?

Ent. Curioso que o seu SR falou a mesma coisa quando ele veio aqui. Ele falou zebra também.

AC Tanta coisa eu num... num sou capá de falar!

Ent. Tenta um pouquinho, se o senhor não... não tem problema nenhum se o senhor não conseguir lembrar.

AC Ah meu deus do céu. Na.

\section{Baleia}


Ent. Não? Não tem problema, fica tranquilo. Vamo lá. E esse daqui? (mostra a figura de uma baleia)

AC Esse daí é aquele lá comé que chama, aquele coi que come a gente lá?

Ent. Que come a gente? (risos)

AC Hum, ai meu deus do céu. Tubarão.

Ent. Tubarão?

AC É. É ou não é?

Ent. Não é.

AC Não é.

Ent. Mas tem a ver. Esse aqu é mais bonzinho que o tubarão.

AC Não sei. Não sei.

Ent. Não? Tudo bem, depois a gente volta e eu vou lembrar o senhor então.

AC Aquele, é zebra aquele lá. (referindo-se novamante à girafa)

Ent. Zebra, esse daqui?

AC Não. Também não é.

\section{Tartaruga}

Ent. Porco, muito bem. E esse aqui? (mostra a figura de uma tartaruga)

AC Bom, parece jacaré. Jacaré não. Cágado.

Ent. Cágado? O senhor lembra das palavras mais difíceis, não lembra das mais fáceis! Serpente...

AC Não, isso aí pra mim é cágado, não tem outra coisa, pra mim é.

Ent. Se ele fosse, se ele vivesse na água...

AC Não t... também.

Ent. Cágado? 
AC Cágado.

Ent. Certo. Pode ser também, é que eu tava pensando num outro, num mais fácil ainda, de lembrar. E esse aqui.

Nos trechos da entrevista apresentados acima, identificamos a dificuldade de acesso lexical e a produção de parafasias pelo paciente, mas comentar outros fenômenos também se faz necessário.

Primeiramente, observamos um fenômeno que veremos nesse sujeito e novamente no discurso do sujeito CP: uma leve perda de hierarquia na nomeação dos animais. Ainda que as respostas dadas sejam válidas, o sujeito apresentou uma idiossincrasia no seu discurso, aparentemente, a hierarquia da organização dos nomes é um pouco diferente do que se esperaria. Uma palavra como "animal" pode ter o seu significado definido como a união de todas as características dos seus hipônimos, portanto, um nome como "cachorro" deveria ser preferido para uma definição mais específica de um objeto, enquanto um nome como "labrador" deveria ser preterido por ser uma palavra mais rara e menos frequente do que "cachorro" (Pulvermüller, 2002). O sujeito apresentou esse fenômeno no trecho sobre a figura de uma tartaruga, apresentado acima, e novamente quando lhe foi pedido que nomeasse a figura de uma cobra:

Ent. E esse.

AC Uma serpente.

Ent. Uma serpente? É, tem o nome serpente e tem o outro nome.

AC É, tem. tem o... tem o... Deixa ver se tem o zigo no na, não tem o vizo não né? Cascavel não é?

Ent. Não...

AC Bom, é aquele que tem o negócio assim.

Ent. Tá. Tá ótimo.

AC Eu não gosto de cobra, eu tô longe disso.

Ent. Cobra. Era esse o nome que eu tava pensando. 


\section{AC Hum.}

Um outro fenômeno que destacamos é o da perseveração. Em um dos trechos acima (durante a nomeação da baleia), vimos que o sujeito insistiu em nomear a figura de uma girafa afirmando que era uma zebra, isso sem ao menos que lhe fosse pedido que a nomeasse novamente. Isso ocorreu mais de uma vez:

AC Como é o nome daquele?

Ent. Ah vamo olhá!

AC É zebra esse aí?

Ent. Não, não é a zebra. É a gi...

AC Hum?

Ent. É a gi...?

AC (Suspiro) Meu deus. Cê sabe que... cê sabe que tá sempre na TV.

Ent. Na TV né?

AC Pois é.

Ent. No zoológico. Girafa.

AC Girafa! Ah minha, meu santo deus.

Além desse exemplo, o tópico escolhido pelo sujeito para definir os animais também pareceu perseverar:

\section{Girafa}

Ent. Vamo lá. Agora sem olhar as figuras, eu vou perguntar pro senhor e o senhor me diz. É... se eu perguntasse pra você: como é que é uma girafa? Como que o senhor descreveria ela pra mim?

AC Bom, que come capim.

Ent. Come capim... 
AC Come capim, outro... outro coiso lá pa pa sobreviver. Certo?

\section{Baleia}

Ent. Como é que é uma baleia?

AC Eu... num... isso aí eu num sei, num sei qual é a vivência dela. Não sei nada.

Ent. Hum, mas o senhor já viu tipo assim... na TV, em desenho?

AC Já vi. Já.

Ent. Então fala pra mim.

AC Num sei o que que ela come, num sei o que que ela faz.

\section{Cavalo}

Ent. Hum hum. Tá, vamo pulá. E como é que é um cavalo?

AC Cavalo come capim...

Ent. Ahãm.

AC Entendeu?

Ent. Sim.

AC É... carrega gente em cima dele. Tá escutando?

Ent. Sim.

AC Põe a... o... o... como é, bota o negócio em cima dele, a... o areio. Entendeu?

Ent. Ahãm.

AC Come... milho. Come tantas coisas lá. Eu tenho muito (incompreensível)

\section{Elefante}

Ent. Entendi, então o senhor vai saber todos os nomes aqui. E seu AC, fala pra mim como que é um elefante. 
AC (Suspiro) Ele come capim. Toneladas de... coiso. E depois num num não sei mais nada dele. Eu diria que tem bastante... oreion. Aquilo deve ser oreia pa caramba.

\section{Gato}

Ent. Que mais, diz pra mim como é que é um gato.

AC Um gato?

Ent. É.

AC (Suspiro) Gato. Tive muito gato também.

Ent. É, e como é que eles são?

AC Gato. Não pode deixar nada de de de de... de peixe pra ele.

Ent. Por quê? Ele come?

AC Urr... e como, e como come. É isso, é isso aí só.

\section{Boi}

Ent. Ixi que trabalho hein. Correr atrás de gato em lugar aberto assim que nem aqui, em sítio. Muito bem. E seu AC como é que é um boi?

AC O boi... o boi gosta de mamar, pra passar, fazer é... churrasco.

Ent. (risos)

intervalo

AC Ah ele é tamanho assim, né?

Ent. Hum hum, grande...

AC Come bastante capim. Entendeu?

Ent. Entendi.

AC E quando dá ração pra ele, ele vai bem também né.

\section{Porco}


Ent. Que medo. Eu teria medo. Que mais, seu AC como é que é um porco?

AC Um porco. O meu pai matava muito porco, e eu ia pegar o sangue do porco, pra fazer choriço.

Ent. Fazer... faz choriço com o sangue dele?

AC É. Fazia choriço, cuzidin, issas coisa aí tudo com o sangue dele. Minha mãe fazia isso aí.

\section{Tartaruga}

Ent. Muito bem, tamo acabando seu AC. Como é que é uma tartaruga?

AC Uma tartaruga. Bom, a tartaruga tem... um bicho que é... ela enfia a cabeça e fica tudo embaixo lá... do coiso lá. Entendeu? Ela vive na água, entendeu?

Ent. Tá.

AC Não... não sei o que eu ela come...

Ent. Tudo bem.

O tópico "comida" foi bastante recorrente no discurso do sujeito. Além de definir oito dos dez animais através do que eles comem — ou por não saber o que eles comem - ele ainda comentou que o boi e o porco são animais usados para fazer choriço e churrasco.

Aparentemente, esse sujeito escolheu esse tema como estratégia para se lembrar das características dos animais solicitados e recorreu a ela sempre que possível.

\subsubsection{Sujeito: CP}

- Nascimento: 11/09/42

- Escolaridade: Ensino Médio Completo

- Resumo: Sujeito do sexo feminino, divorciada, com 67 anos de idade, artista plástica. Embolização de aneurisma cerebral realizado em 05/06/2008. Foram identificados dois aneurismas da carótida interna 
esquerda. Em tomografia computadorizada do crânio, realizada em o6/o6/2008, foi observada extensa hemorragia subaraquinóidea notadamente à esquerda, ocupando a fossa média e a região frontal e parietal, bem como sisternas quadrigeminal e perimesenfálicas, fissuras de Sylvios interehisférica. Nota-se aréa hiperdensa (sangue) na região fronto-parietal esquerda, compatível com hemorragia intraparenquimatosa. Apagamento difuso de sulcos corticais e fissuras, representando edema. Conclusão: achados compatíveis com AVC hemorrágico à esquerda, associado à herniação, subfalcinal contralateral e edema cerebral. Em 23/o6/2008, também por tomografia do crânio, houve controle de drenagem de hematoma: enfarto nos territórios das artérias cerebrais media e posterior à esquerda, com acentuado efeito de massa e marcado desvio contralateral do hemisfério. 12/2009 tomografia computadorizada, na qual foram observados os seguintes aspectos: craniotomia fronto-temporo-parietal esquerda. Sinais de clipagem de aneurisma na região para-selar esquerda com material cirúrgico, ocasionando artefatos na imagem obtida. Extensa área de encefalomalácea fronto-têmporo-parietal esquerda, no território da cerebral média esquerda, com envolvimento núcleocapicilar e talâmico homolaterais, calcificações distróficas na região occipito-parietal esquerda, de aspecto residual. Hipótese diagnóstica: craniotomia fronto-têmporo-parietal esquerda. Sinais de clipagem aneurismática na região para-selar esquerda. Extensa área de encéfalomalácea fronto-têmporo-parietal esquerda, indicativo de isquemia no território da cerebral média esquerda.

Esse sujeito apresenta diversos déficits de linguagem. Durante a entrevista, apresentou grande dificuldade de acesso lexical, parafasias, fenômenos fonológicos e alguns poucos fenômenos sintáticos. A seguir apresentamos partes das entrevistas nas quais podemos observar características do seu discurso. Começaremos com a dificuldade de acesso lexical:

Ent. Muito bem. E esse daqui?

CP ... ai não sei... se vai... ai não sei, aqui ó, muito parecido... ai eu não sei não.

Ent. Não tem problema. Vamo pulá. E esse aqui? 
CP ... ai num sei não. Falá. Hum... é...

Ent. Não?

CP Eu não sei porque ali ó, não sai.

Ent. Não.

CP Mas eu... Tá ali.

A seguir, podemos observar dados de parafasias:

\section{Baleia:}

Ent. Eu vou mostrando um por um pra senhora...

CP Eu lembro aqui, mas é... gi-rafa.

Ent. Girafa, muito bem, eu vou mostrando um por um pra senhora a senhora diz o que a senhora conseguir lembrar, tá? E esse aqui? (mostra a figura de uma baleia)

CP Golfinho.

\section{Elefante:}

Ent. Isso. Ótimo. (a entrevistadora mostra a figura de um elefante)

CP Girafa. Ah... pronto não sei, porque essa aqui... ah não...

Ent. Esse aqui não?

CP Mas elefante não é, aqui é uma...

Ent. A senhora acabou de falar!

\section{CP Hã?}

Ent. A senhora falou sem querer, o nome dele.

CP Girafa não. Não sei onde. Ah não sei não.

Ent. Mas a senhora falou sem querer, a senhora fala "esse aqui, mas não", mas era ele mesmo. 
CP Girafa não. Não sei.

Ent. Elefante. Elefante.

CP Não sei.

Ent. Não? Olha aqui pra mim. Elefante.

CP Mas ela conseguiu, ela só que ela fica dentro, e a gente não... não sabe.

Ent. Elefante.

CP É. Se... um elefante.

Esse dado é especialmente curioso pois em seguida à parafasia elefante/ girafa, o sujeito produziu o nome "elefante" sem mesmo se dar conta, além disso, a entrevistadora teve que repetir a palavra várias vezes até o sujeito conseguir repeti-la. Segundo Jakobson (1966) se a palavra requisitada for livre de contexto, a operação de procura da palavra se torna uma tarefa impossível para um afásico severamente afetado por um transtorno de seleção (similaridade). Tal sujeito frequentemente seria incapaz de responder através da repetição de uma palavra, ainda que a mesma palavra possa ser pronunciada facilmente dentro de um contexto. Alguns pacientes chegam a responder à solicitação de repetir a palavra "não" dizendo "não, não consigo".

Algo parecido com uma parafasia aconteceu com os nomes "cavalo" e "cobra". Esse fenômeno foi apresentado anteriormente no discurso do sujeito AC. Nos trechos a seguir, podemos observar dois momentos nos quais o sujeito optou por usar uma palavra de nível mais baixo do que o hiperônimo "animal", mas ainda mais baixo do que os hipônimos "cavalo" e "cobra".

\section{Cavalo:}

(A entrevistadora mostra a figura de um cavalo)

CP Ai... humm.., pronto ó. Essa demora que... corcel, mas não é bem o...

Ent. Mas tem a ver.

CP Mas não... 
Ent. Cavalo.

CP É (risos).

Ent. Isso. Ótimo.

\section{Cobra:}

Ent. Tá na ponta da língua mas não sai né?

CP É... Touro.

Ent. Touro, muito bem. E essa daqui? (a entrevistadora mostra a figura de uma cobra)

CP O que que é isso? Não sei... ah! É a... nara... lara... não. Ah eu não sei.

Ent. Cobra.

CP Ah nossa, tudo assim.

Ent. É que a senhora devia tá tentando falar...

CP Não não...

Dentre esses dados apresentados acima, podemos também observar alguns fenômenos de natureza fonológica, e eventuais fenômenos de natureza sintática, destacados a seguir.

No primeiro recorte, podemos ver que na tentativa de nomear a figura de uma cobra, aparentemente o sujeito tentou utilizar a palavra "naja", mas não conseguiu acessar os fonemas corretos para produzir tal nome.

Ent. Touro, muito bem. E essa daqui?

CP O que que é isso? Não sei... ah! É a... nara... lara... não. Ah eu não sei.

Ent. Cobra.

CP Ah nossa, tudo assim.

Ent. É que a senhora devia ta tentando falar...

CP Não não... 
Além desse dado, quando foi pedido ao sujeito que definisse uma cobra, a resposta teve interferência lexical e fonológica:

Ent. Bravo, muito bem. Como é uma cobra?

\section{CP Ninja.}

Em geral, esse sujeito não apresenta características de agramatismo, mas em alguns momentos a escolha do pronome e da sua conjugação correta sofreu prejuízos. Acreditamos que, uma vez que o sujeito não pareça ter problemas de combinação, seja possível que isso tenha se dado não por um transtorno gramatical, mas por um lapso ao tentar acessar o pronome desejado.

\section{Primeiro recorte:}

Ent. Não? Olha aqui pra mim. Elefante.

CP Mas ela conseguiu, ela só que ela fica dentro, e a gente não... não sabe.

Ent. Elefante.

CP É.Se... um elefante.

\section{Segundo recorte:}

Ent. Não? Se a senhora me falar assim, faz de conta que eu nunca vi uma girafa, aí eu chego "não, dona $\mathrm{CP}$, como que é uma girafa?" uma palavra que a senhora lembrar...

CP Girafa...

Ent. A senhora lembra qual bicho é a girafa?

CP Ele sabe... (risos)

Ent. Lembra?

CP É!

Ent. Às vezes esquece...

CP Não... 


\section{Terceiro recorte:}

CP Ah eu num sei. Tá...

Ent. O barulho de fora tá atrapalhando a senhora?

CP É. Eu fala, os outro fala. Não sei. Não.

Ent. Atrapalha? Não tem problema, vamo pulá então. Lembrou alguma coisa?

CP Ba... bravo.

\subsubsection{Sujeito: DP}

- Nascimento: 1939

- Escolaridade: Não consta.

- Resumo: Sujeito do sexo feminino, casada, com 71 anos de idade, fiscal do INSS aposentada. Tomografia computadorizada, realizada em 04/2004, indica área sugestiva de AVCi "área hipodensa, irregular, com contornos mal definidos, localizada na substância branca adjacente ao corno posterior do ventrículo lateral esquerdo, sugestiva de área de AVCi, alargamento simétrico e bilaterial das sisternas da base e dos sulcos entre as folias cerebelares". Ressonância magnética de 05/2004 indica "sinais de hiperostose frontal difusa e bilateral, assimétrica, exuberante em hemicrânio esquerda, sisternas da base e fissuras sylvianas amplas; alargamento difuso, aqui relativamente simétrico e bilaterial dos sulcos corticais, notadamente em regiões parietais, denotando redução nas espessuras do parênquima encefálico cortical. Presença de focos puntiformes de hipersinal esparsos nos núcleos da base, bilateralmente, indicando proeminência de espaços peri-vasculares. Pequenos focos de sinal ovalados, esparsos pela região subcortical do lobo parietal a esquerda, que podem corresponder a seqüelas de AVCi lacunar". Conclusão: sinais de redução volumétrica cortical, notadamente em regiões parietais. Relata dificuldades de memória. 
Esse sujeito não apresenta nenhum problema de codificação, compreensão ou agramatismo. Apresenta apenas falhas leves no acesso lexical e parafasias, que podemos ver a seguir:

\section{Baleia:}

Ent. Muito bem. (mostra uma figura de uma girafa)

DP Uma girafa.

Ent. Muito bem. (mostra a figura de uma baleia)

DP Ah, esse daí é o... como é que chama... não é golfinho é o... é o outro. Tá vendo, não é assim...

Ent. Não é assim né...

DP Não é assim, como você tá pensando.

Ent. Mas a senhora tá ótima.

DP É... ai meu deus! Eu vou lembrar! Depois.

Ent. Depois? Então vou deixar ela aqui.

DP Agora eu não lembro, não olho...

\section{Burro:}

Ent. E o último. (mostra a figura de um burro)

DP Esse aí é bezerro né? Não, não é, é... pônei, não é pônei. É... lá do nordeste... ai meu deus... trabalhei lá, ele ficava na janela do meu quarto! Era... jegue!

Ent. Jegue? Tem um outro nome. "Jegue" serve também, mas só pra ver se a senhora lembra o outro nome, que é mais comum. Pelo menos aqui em São Paulo é mais comum.

DP É... esqueci agora. Não vou lembrar.

Ent. Não?

DP Não. 
Ent. Burro.

DP É o burro, isso.

Novamente, foi pedido que nomeasse a baleia:

Ent. Agora a gente vai voltar praquele lá que a senhora não lembrou.(mostra a figura de uma baleia)

DP Ai, como é que é... humm...

Ent. Mas a senhora sabe qual que é e só não lembra o nome.

DP Não, eu sei qual que é, eu sempre compro peixe aí o meu marido fala "esse daí é..." é do mar... não lembro.

Ent. Mas esse não é aquele que morde.

DP É, esse é.

Ent. Não, esse daqui não era pra ser esse, não. Esse era pra ser o outro que é mais bonzinho.

DP Ah, então é o peixe, comum.

Ent. Comum não.

DP Não é... tem o golfinho, não é né? É golfinho, não é?...

Ent. Baleia.

DP Baleia. Mas a baleia morde.

Ent. Morde?

DP Morde.

Ent. É que eu pensei que a senhora tava pensando em tubarão.

DP Não, não, baleia.

Ent. Porque a senhora falou que vai na feira e tal, porque tem gente que compra... 
DP Não a gente compra aquela... aquela... é... aquele pedaço do peixe que o meu marido fala "isso daí é tubarão".

Ent. É. Cação, né?

DP É, cação.

\subsubsection{Sujeito: JN}

- Nascimento: 05/08/1944

- Escolaridade: Ensino Fundamental Incompleto

- Resumo: Sujeito do sexo masculino, casado, com 66 anos de idade metalúrgico aposentado, que sofreu um AVCi (acidente vascular cerebral isquêmico) em o6/o8/20o8, resultando em uma lesão têmporoparietal esquerda. JN tem afasia predominantemente de expressão, marcada por dificuldade de acesso lexical (seleção) e pela produção de parafasias. Produz algumas expressões cristalizadas como: "eu não consigo", "não dá pra falar", "é difícil de falar", "calma, espera um pouco".

Durante as entrevistas pudemos ver que este sujeito, assim como o sujeito $\mathrm{CP}$, apresenta dificuldades severas de comunicação, especialmente afetada pelos problemas de acesso lexical, como os que apresentamos a seguir extraídos das entrevistas:

Ent. Tá ótimo, duas coisas tá ótimo já, ela é grande e ela tem quatro patas. Tem problema nenhum. Se eu perguntar pro senhor como é um elefante, o que o senhor consegue me dizer do elefante?

JN Falar o nome...

Ent. Não precisa falar o nome dele, só quero que o senhor me diga assim, ele é... sei lá, que cor que ele é... o tamanho...

JN É grande...

Ent. Ele é grande...

JN Tem... tam.. aqui a bo... 
Ent. Tem a tromba...

JN É, mas num... lá, lá, lá...

Ent. Fica ali, hum hum... o nariz dele é compridão...

JN É, isso... hum.. aqui... bã... aqui, hum... falar, é muito grande também...

Ent. A orelha é grande...

JN É, é. E mais...

Esse recorte da entrevista nos faz perceber como a dificuldade de acesso lexical é realmente a principal característica do déficit apresentado por esse sujeito. Suas orações raramente apresentam um sujeito explícito. JN usou em todos os momentos a estratégia de apontar para a figura para que a entrevistadora soubesse que parte do animal ele descrevia, mas os nomes nunca foram citados.

Quanto às questões fonológicas, em vários momentos da entrevista podemos observar que esse sujeito é capaz de recuperar traços fonológicos das palavras que tenta recuperar. Foi solicitado ao sujeito que nomeasse alguns animais. Vejamos alguns exemplos:

\section{Girafa:}

Ent. (risos) Vamo vê, o que o senhor souber, se lembrar, lembrou, senão não tem problema nenhum.

JN É, pois é.

Ent. Esse aqui. (a entrevistadora mostra a figura de uma girafa)

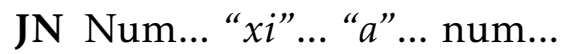

Ent. Tá na ponta da língua né?

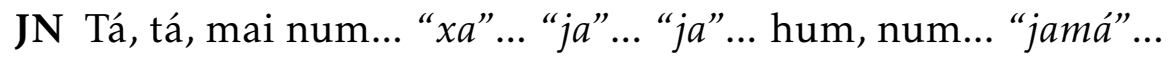

Ent. Num fique nervoso! Não tem problema. Eu só to vendo...

JN Eu sei, eu sei, mas eu num falo, eu num... 
Ent. É que se o senhor souber ou não souber, ainda assim vai ser útil pra entender o que ta acontecendo com o senhor.

JN É “ja” “shhh”...

Ent. Tudo bem, é um bom começo. E essa daqui?

O mesmo aconteceu com o nome "burro":

\section{Burro:}

Ent. Não? E esse aqui?

JN “Bu”... “bu”, “bur”..."bugre”, não. “bu”... “Burr”... “bugre” não. “Bu”... "bu”... não...

Ent. Não sai o finalzinho né?

JN Não, não falo.

Ent. Mas o começo tá certo.

JN Mas, não... não tem jeito... tá bom, mas nóis vai lá! Nóis vai!

Ent. Vamo! Tudo bem.

JN “Bugra”, não.

Ent. Por aí! O senhor não tá falando, mas tá melhorando.

Uma das figuras a ser nomeada foi a figura de uma cavalo, a qual o sujeito respondeu prontamente:

Ent. Tá. (mostra a figura de um cavalo)

JN Ca-valo.

Ent. Ah sim!

JN Tá bom? (risos)

Ent. Muito bem. É o cavalo, ótimo. 
No entanto, podemos observar que a nomeação das figuras seguintes parecem ter sofrido com a perseveração do nome "cavalo".

Ent. Muito bem. É o cavalo, ótimo. (mostra a figura de um elefante)

JN ... Eu sei, mas não sai...

Ent. Não tem problema nenhum, não to testando o senhor hein?

JN Sim eu sei. Mas eu quero, quero...

Ent. O senhor quer falar mas é difícil né?

JN É, isso, “vac”... “va”... não...

Ent. Só por esses sons que o senhor tá fazendo eu to vendo que tá... tá em algum lugar!

No trecho a seguir podemos ver ainda a perseveração do nome "cavalo", uma vez que o nome pedido imediatamente depois (o elefante) não foi acessado pelo sujeito. Nessa parte da entrevista podemos ver também uma interferência fonológica na perseveração (o sujeito insistiu na cadeia sonora [va], mas adicionou o [g]), além de uma interferência semântica (gato/ cachorro):

Ent. Difícil?

JN Num tem jeito não...

Ent. Não tem problema... (a entrevistadora mostra a figura de um gato)

JN “Vag”, “vag”... agora... “va”... “va”... (risos) “vale”... não... “va”..."ve”... não... "cacho"... cachorro, cachorro não, cavalo, não, é... num falo...

Ent. Mas, tá certo, tá certo...

JN É bom, é fala, mas num fala né? Eu queria falar! Eu quero falar! Isso num tem... mai num...

Ent. Mas tá melhorando.

Durante a tentativa de descrição do porco, o sujeito demonstrou por gestos que queria dizer "gordo", mas disse "bobo". 
Ent. Tem o focinho... hum hum...

JN E... é... dois dois olho...

Ent. Dois olhos, hum hum...

JN Vamo... v... que... é... hum... ai num vai, num vai...

Ent. Tem o rabinho enrolado?

JN Isto... cach... e bo... bastante... bobo...

Ent. É gordinho?

JN Gor-do... é então, assim... e... hum... eu quero! Quando era, quando... falo, hummm eu quero falar, mas eu quero uma coisa...

A habilidade de repetição parece estar prejudicada.

Ent. Tem dois olhos?

JN Isto. E... hum... ficin... hum...

Ent. Focinho.

JN Ficin... é mas... ficin

Ent. Focinho.

JN Ficin, ficin, ficin...

Ent. Fo-cinho.

JN Fuиu...

Ent. Fo-ci-nho.

JN Fuzin, fucin, fucin...

Uma característica importante do discurso desse sujeito é que a abstração para a descrição dos animais parece estar prejudicada. O sujeito só conseguiu descrever os animais enquanto olhava para as figuras, e sua descrição foi totalmente baseada em características físicas.

Apesar da dificuldade na evocação de palavras, o sujeito demonstrou compreender todos os nomes apresentados. 


\subsubsection{Sujeito: SR}

- Nascimento: 15/10/1952

\section{- Escolaridade:}

- Resumo: O sujeito é casado, tem quatro filhos e é encanador industrial aposentado. Teve AVC isquêmico em Dezembro de 2005. A ressonância magnética do crânio e angio-ressonância demonstraram sequelas subagudas de AVC em território da Artéria Cerebral Média, comprometendo desde região frontal até ínsula, lobos parietal, temporal e occipital esquerdos. O paciente tem histórico psiquiátrico, com quadro de depressão prévio ao AVC. Frequenta o CCA desde agosto de 2006.

Esse sujeito, assim como os que foram apresentados antes dele, demonstrou alguma dificuldade de acesso lexical e parafasias. Ele possui uma leve apraxia de fala, mas seu discurso é relativamente fluente. Observamos também indícios do que pode ser um leve prejuízo gramatical e alguns fenômenos fonológicos.

Vejamos os exemplos de dificuldade de acesso lexical:

\section{Girafa}

Ent. Tá, então vamo lá, então já tem uma ajuda aí né? Vamo então que eu vou fazer, vou mostrar as fotos e o senhor diz pra mim se o senhor consegue lembrar ou não.

SR A zeba né? É... Ela vive na África né?

Ent. hum hum, como é o nome que o senhor disse?

SR A zebra né. A zeba.

\section{Baleia}

Ent. Tá bom. Sem problema, muito bem (mostra a figura de uma baleia)

SR O tubarão né, é um peixe.

\section{Açougueiro}


SR Ele ele demonta. Só pode sangrar de uma vez. Ele não po... não tem... quase força nenhum. Ele sanga e pode tirar o couro e abrir.

Ent. Entendi.

SR A... o... o... o... a... os... os cara. Eu não consigo a palavra certa. Ele, ele, ele mata o boi assim.

Ent. O açougueiro?

SR Isso, é. O açougueiro distincha as peça né? Ele mais ou menos isso.

Assim como os sujeitos que confundiram os nomes "baleia" e "girafa", pode-se notar que as parafasias tendem a ser nomes aproximados aos nomes alvo. Outros sujeitos assim como SR relacionaram baleia a tubarão e girafa a zebra.

Podemos notar no trecho acima que SR também apresenta algumas dificuldades fonológicas. É possível que essas dificuldades estejam relacionadas com a apraxia de fala, bastante notável nesse sujeito, destacamos algumas a seguir:

Lefante - elefante; diano - indiano; areia - orelha

Ent. Hum hum, tá ótimo como é então, seu SR, o elefante?

SR O elefante?

(Interrupção)

SR O lefante ela... ele é natural da África, é nemal grande também. Ele... ele pode... pode... andar de cavalo também.

Ent. Ahãm, dá pra andar em cima dele também...

SR É o diano anda lá... tem um marfim valioso, né? Areia grande... mais ou menos...

\section{Lefante, alefante - elefante}

Ent. É o senhor tem a ajuda aí de ter morado em sítio né. Vamos ver, tem vários animais aqui de sítio, vamos ver se o senhor lembra melhor deles então. (mostra a figura de um elefante) 
SR O lefante né.

Ent. Hum hum.

SR Alefante.

Ent. Elefante. Muito bem.

\section{Coba - cobra}

Ent. O boi, hum hum. (mostra a figura de uma cobra)

SR Uma coba. É.

Ent. Muito bem.

\section{Cardaru - tartaruga}

Ent. É... mas matar, né? Eles gritam... não teria coragem não, ainda bem que o senhor tem, senão não ia comer porco. E esse daqui?

SR Jabuti.

Ent. Hum hum muito bem. Tem um outro nome?

\section{Cardaru.}

Ent. Tartaruga, muito bem.

Roçava; nono - dono; coscava - mandava; maná, mandá - matar

SR Não, não... eu trabalhava de... a fazenda, né?

Ent. Ahãm.

SR (Incompreensível) a fazenda. Eu roça... eu roça... eu roçava pasto. É uma serra, tinha muita cascavel.

Ent. Nossa, que perigo. 
SR É. O nono da fazenda ele coscava maná tudo porque a cascavel pica os boi. Mata. Ele gostava mandá tudo as cobra que achava. A fazenda muito... muito grande, acho que... não lembo não, mas teve sim, nós cava três mês no pasto. Eu tinha o meu pai tinha cinco filho homem formado. Eu trabalhava com ele desde criança e nóis cavava junto cinco, seis pessoa. Cinco... seis pessoa. Três mês por ano. Vez por outra, tudo ano, eu... ele pegava empretada para roçar o pasto.

\section{Relative - relativamente}

Ent. Ahãm, conhece bastante e fala bem também. Tamo acabando já seu SR. Fala pra mim como é um porco.

SR O porco... e... ele... rela tive... rela tive... pequeno. É, não é muito grande não.

Títio - sítio

Ent. Muito bem. (mostra a figura de um porco)

SR O porco. Matei muito porco.

Ent. Sério? Seu SR! Não dá medo não? Não dá aflição?

SR Não... mas... no títio tinha matar para comer. A gordura... a carne... tinha, necessário.

Além dos itens acima, SR também apresentou uma leve dificuldade gramatical. Em geral, seu discurso foi bastante fluente, mas alguns deslizes serão destacados aqui:

\section{Primeiro recorte}

Ent. Hum hum.

É, porque ela balançava quando tem pobrema, ela avisa para não chegar perto dela. É, ma... mais ou menos essa disquição. Ela cor rajada, também.

\section{Segundo recorte}

Ent. Sério? Seu SR! Não dá medo não? Não dá aflição? 
SR Não... mas... no títio tinha matar para comer. A gordura... a carne... tinha, necessário.

\section{Terceiro recorte}

Ent. E eles conversam bastante com o senhor?

SR Mais ou meno. Mas eu... ele... conversa mais ca a minha esposa.

Ent. Hum hum. 


\section{Capítulo 11}

\section{As metáforas}

Os dados retirados das entrevistas apresentados anteriormente mostram alguns exemplos dos déficits de linguagem obervados nos sujeitos afásicos que participam dessa pesquisa. Baseando-nos nos resultados obtidos e nos dados clínicos dos sujeitos, acreditamos que os prejuízos observados acima podem ser caracterizados como transtornos predominantemente na decodificação, que levam à afasia sensorial, baseando-nos na descrição de Jakobson.

O sujeitos entrevistados não apresentaram prejuízos significativos de ordem gramatical. O uso de conectivos, artigos e pronomes, que servem para fortalecer o contexto gramatical, permanecem satisfatórios no discurso desses sujeitos. Por outro lado, podemos encontrar em seus discursos diversas características da afasia sensorial, como o empobrecimento da variedade de substantivos e o fato de as sentenças sintáticas estarem preservadas (assim como os elementos que servem para construir sentenças), e o predicado parecer mais estável do que o sujeito nas orações (características apresentadas por Jakobson como sintomas do transtorno de similaridade, principal prejuízo da desordem de decodificação).

Feitas essas distinções, a partir de agora veremos os dados da segunda entrevista realizada para o desenvolvimento deste trabalho. Após a apresentação das figuras de animais e da nomeação e definição feitas pelos afásicos, a tarefa que se seguiu foi utilizar tais nomes como metáforas: os mesmos nomes de animais apresentados anteriormente foram colocados em situações contextualizadas para que os entrevistados apontassem quais os nomes (metafóricos) mais adequados a cada situação proposta. 


\subsection{O contexto como facilitador do acesso lexi- cal}

Na segunda entrevista, os sujeitos foram colocados em situações "conflitantes", se levarmos em consideração as teorias de Jakobson sobre o funcionamento das afasias.

Jakobson afirma que sujeitos com relações internas prejudicadas e relações externas intactas (como acreditamos ser o caso dos sujeitos apresentados aqui) são capazes de seguir e completar um contexto. Como a atenção desse sujeito estaria totalmente voltada para a construção do contexto, frequentemente ele exibirá habilidade em completar uma palavra fragmentada ou a parte de uma sentença que lhe seja apresentada. Essa atividade seria, portanto, facilmente realizada pelos indivíduos apresentados, presumindo que suas dificuldades linguísticas fossem amenizadas numa situação como esta, na qual a tarefa pedida é o preenchimento de uma sentença:

Ent. Eu posso... eu vou perguntando pra senhora, a senhora me diz, tá? Se eu disser assim "O João é muito gordo, o João é um..."

DP Elefante.

No entanto, a habilidade linguística necessária para tanto não é só a habilidade para completar sentenças. Mais do que apenas completá-las, os sujeitos tiveram de utilizar para isso uma metáfora, o que dificultaria para eles essa tarefa significativamente. Ainda segundo Jakobson, os afásicos com a relação interna prejudicada têm dificuldade em organizar unidades do código linguístico de acordo com a sua similaridade; seriam capazes de combinar duas unidades dentro da mensagem, mas não de substituir uma unidade por outra com base em semelhança mútua. Sendo assim, as metáforas seriam figuras do discurso que dificilmente seriam acessadas por eles.

Quando apresentamos no capítulo 3 as estruturas das redes de formas de palavras, dissemos que, se os neurônios de uma rede funcional são necessários para o processamento perfeito de uma entidade, uma lesão em uma porção significativa da rede de neurônios deve prejudicar o processamento dessa entidade, independentemente de onde essa lesão ocorrer. No entanto, se uma rede de neurônios guarda a representação de memória 
de um objeto, e cada neurônio representar uma característica desse objeto, a ignição completa seria a ativação da sua representação armazenada, e essa ativação pode acontecer mesmo que apenas uma fração das características do objeto esteja presente no input. Como afirmamos no capítulo 3, se de fato uma ativação puder ser completada organicamente através de poucas características de um objeto, a ativação de algumas características semânticas desse objeto pode levar à completa ativação do seu nome (cf. Levelt (1989))e, desse modo, os sujeitos que apresentam problemas de acesso lexical poderiam encontrar diferentes caminhos, através da ativação de diferentes características, para alcançar uma palavra ou um conceito até então perdidos.

O que podemos ver pelas entrevistas é que, seja devido aos diferentes caminhos neuronais necessários para o acesso ao nome, seja pelo contexto linguístico facilitando esse acesso, o contexto inserido na necessidade da apresentação da linguagem não-literal é um elemento facilitador na produção das metáforas.

No que diz respito à compreensão, pudemos perceber que a compreensão dos nomes de animais utilizados em um contexto que exigisse a abstração para o uso metafórico apresentou resultados diferentes quando comparados à habilidade de produção. Ou seja, os sujeitos tiveram dificuldades consideravelmente maiores para compreender as metáforas do que tiveram para enunciá-las.

A princípio, dado que acreditamos que esses sujeitos teriam realmente maiores problemas de compreensão do que de produção (já que, de acordo com a teoria de Jakobson, eles estariam mais propensos a problemas de decodificação), esse resultado seria esperado. Contudo, verificamos que durante toda a entrevista os afásicos não apresentaram nenhum indício de inabilidade para compreensão, o que nos faz supor que a adição desses dois elementos impeditivos (a dificuldade de compreensão geral e apresentação da metáfora) resultariam numa dificuldade palpável para a manutenção de um tópico a ser feita pelos sujeitos. Sendo assim, devemos ressaltar que as metáforas em geral, ainda de acordo com Jakobson, deveriam sozinhas ser uma habilidade linguística em desvantagem no discurso desses sujeitos, mas vimos que a sua produção aliada à contextualização dos momentos em que ela seria necessária deu a eles uma ferramenta com a qual contar para facilitar essa dificuldade.

Segundo Jakobson (1973), o motivo pelo qual os sujeitos com transtorno de similaridade teriam dificuldade para a seleção dos itens do discurso 
Metáforas: produção e compreensão

(enquanto os sujeitos com transtorno de combinação teriam dificuldade para a produção de contexto) é que a codificação começaria com a seleção de constituentes que devem ser combinados e integrados em um contexto. A seleção é o antecedente, enquanto a escolha do contexto é a consequência ou o alvo do codificador. Para o decodificador, essa ordem é inversa. Primeiro, o decodificador encontra o contexto; a seguir, deve detectar os constituentes. A combinação é o antecedente, a seleção é a consequência, o alvo do processo de decodificação. O codificador começa com uma operação analítica que é seguida pela síntese; o decodificador recebe a informação sintetizada e começa sua análise. Na afasia, a consequência é a prejudicada, enquanto o antecedente se mantém intacto; a combinação, portanto, é deficiente na afasia quando há problemas de codificação, e a seleção é deficiente quando há problemas na decodificação.

Sendo assim, temos um ponto a acrescentar às motivações que causam os prejuízos apresentadas por Jakobson para explicar a dificuldade de decodificação: dado que os sujeitos com transtorno de similaridade se apoiam no contexto para decodificar uma mensagem, a falta de contexto é um fator agravante da condição dos sujeitos com esse tipo de afasia.

Para essa parte da entrevista, os sujeitos até mesmo tiveram acesso a alternativas que ajudariam no acesso aos significados das metáforas, o que mostra que a dificuldade de compreensão foi realmente mais prejudicada no que diz respeito ao uso da linguagem não-literal num diálogo com esses sujeitos.

\subsection{Metáforas: produção e compreensão}

Nesta seção, apresentaremos e comentaremos os recortes mais relevantes dos protocolos aplicados aos sujeitos ${ }^{1}$.

\subsubsection{Sujeito CP}

O sujeito CP foi o melhor exemplo de como o contexto criou uma via facilitadora para o acesso aos nomes utilizados como metáforas. Podemos ver nos trechos extraídos da entrevista que nos momentos em que a entrevistadora proveu o sujeito com o contexto apropriado para a utilização da linguagem

\footnotetext{
${ }^{1}$ As transcrições serão apresentadas integralmente no anexo II.
} 
não-literal, ou mesmo com a tarefa de completar a frase, suas respostas foram dadas de acordo com o uso costumeiro desses nomes, lembrando até mesmo mais nomes utilizados como metáfora do que lembrou no seu uso literal - embora isso não tenha acontecido com os dois primeiros exemplos indicados a seguir:

Ent. Tá bom. E se eu falasse assim... “a Maria é muito gorda”?

CP Na...gir...

Ent. A girafa? Quer dizer que a Maria é muito gorda?

CP (risos) Ua gira...

Ent. Tá bom, e se eu dissesse assim, é... “O João, ele é muito grosso”?

CP Também.

Já na produção das demais metáforas, com a devida apresentação de contexto, o sujeito obteve sucesso:

\section{Gato}

Ent. Muito bem. Vamo ver se eu falasse assim "dona CP, o... João, ele é muito bonito, o João é lindo, o João é um..."?

CP Assim.

Ent. Isso, que é o...como é nome?

CP Porc/ é... Gato.

A resposta dada para a próxima contextualização não foi exatamente "cobra". No entanto, o sujeito se manteve fiel à nomeação que havia feito mesmo quando o nome foi utilizado em sentido literal (ao invés de "cobra", o sujeito tentou dizer "naja”):

\section{Cobra}

Ent. Acho que confundiu a senhora porque esses dois são meio parecidos né? Vou fazer/ vou trocar aqui um pouquinho. Depois a gente faz de novo que eu achei que ficou, ficaram parecidas. Se eu falar assim dona CP "a Maria, ela é muito maldosa, ela fala mal dos outros pelas costas, ela...faz fofoca... a Maria é uma...” 
CP Hum...a...hum...ai...uma jarra. Najarra.

\section{Elefante}

Ent. "O João é muito gordo".

CP Esse aqui também.

Ent. Hum, qual o nome? "O João é um..."?

CP Um etefante. O... ai.

\section{Lesma}

Ent. Vamo lá dona CP, se eu falasse assim... não gostei dessa ordem também, deixa eu trocar. Se eu falasse assim "A Maria...é muito lenta. Nossa, ela é muito devagar essa menina..." isso, qual o nome? "A Maria, é muito devagar essa menina! A Maria é uma..."?

CP Ah eu num sei nu... num... não o... eu não sei qual que é o num... num num. .

Ent. Você não lembra o nome desse bicho não? Nem fazendo uma forcinha? "A Maria é muito devagar, meu deus, a Maria é uma..."

CP Nesma... então...

\section{Porco}

Ent. Não? Não tem problema. Vamo pulá esse daqui, trocar por esse. Se eu falasse assim, dona CP, "o João é muito sujo. Ele não toma banho, ele não escova os dentes..."

CP Ai é... (risos)

Ent. Esse! E qual o nome dele? “O João é um...”?

CP Corco...cor...

Ent. É quase isso.

CP Por-co. 


\section{Touro}

Ent. "O João é tão forte, o João é um..."

CP Ah é...é isso mesmo... o... porco não... mai esse, não...

Ent. “O João é tão forte, o João é um..."

CP Touro!

\section{Burro}

Ent. Esse daí é o porco, é, vou tirar daqui pra não atrapalhar a senhora, ver se você lembra melhor. "Nossa João, como você é..." "Você faz tudo errado, meu deus, como você é..."?

CP Eu sei... ahh... sai... não sai... mas que coisa...burro.

Quanto à compreensão, temos muitos exemplos de como o seu resultado não foi tão satisfatório quanto o da produção de metáforas. O sujeito precisou ouvir as opções de significado das metáforas, e ainda assim teve mais dificuldade para compreendê-las do que para produzi-las. Citaremos apenas um de cada sujeito:

Ent. Isso! Perfeito dona CP, muito bem. Agora a segunda parte, agora eu vou fazer o contrário. Eu vou falar pra senhora os nomes dos animais e eu quero ver o que que a senhora entende... se eu chamar uma pessoa por esse nome, tá?

CP Hum.

Ent. Então, por exemplo, se eu falar assim: “o João é um elefante”, o que eu quero dizer?

CP Hum... por que vai...

Ent. Isso, por que que eu vou chamar ele de elefante? "Nossa, o João é um elefante" eu tô querendo dizer o quê, do João?

CP Ah, não sei não... 
Ent. Não? Vou dar então três opções pra senhora tá? Se eu falar que o João é um elefante eu quero dizer que o João é gordo, que o João é desleixado ou que o João é invejoso?

CP Hum.

Ent. “O João é um elefante", gordo, desleixado ou invejoso?

CP Ah, é! Isso... tão peraí...

Ent. (risos) Agora a senhora entendeu né?

CP (risos) Eu...eu... mas é muito.

Ent. Quer que eu fale de novo?

CP Pode falar.

Ent. "O João é um elefante" quer dizer que o João é gordo, quer dizer que o João é desleixado ou quer dizer que o João é invejoso?

CP Re... In-vejoso.

Para uma melhor visualização desses resultados, apresentamos a tabela 10.1 .

\subsubsection{Sujeito AA}

O sujeito AA conseguiu produzir sete dos dez nomes de animais apresentados em contexto não-literal. Podemos perceber nos trechos transcritos a seguir que a entrevistadora proveu o sujeito com o contexto necessário para o acesso à metáfora em todas as ocasiões, o que, acreditamos, facilitou a sua produção.

\section{Cavalo}

Ent. Não? Desses bichos não lembra nenhum? Se eu fizer assim "O João... ele, ele é muito grosso, ele trata as pessoas mal, fica dando patada..."

AA Ah...hum não... 


\begin{tabular}{ll}
\hline Animal & Resposta do paciente \\
\hline "O João é um elefante" & invejoso \\
"O João é um cavalo" & grosso \\
"O João é um gato" & honesto \\
"O João é um touro" & engraçado \\
"A Maria é uma girafa" & feia \\
"A Maria é uma cobra" & maldosa \\
"O João é um burro" & não é inteligente \\
"A Maria é uma baleia" & gorda \\
"O João é um porco" & sujo \\
"A Maria é uma tartaruga" & lenta \\
\hline
\end{tabular}

Tabela 11.1: Definição de metáforas do sujeito CP. O sujeito teve de observar as figuras enquanto respondia

Ent. Isso, será que você lembra o nome? É esse mesmo que você tá falando, que você tá fazendo assim.

AA É o cava.

Ent. Cavalo, muito bem AA, exatamente isso.

\section{Girafa}

Ent. E se eu falar assim, se eu falar assim AA, “a Maria é muito alta, gente a Maria é alta demais, olha o tamanho dessa menina, ela é uma...?"

AA Ah... a gira...

\section{Cobra}

Ent. Girafa. Muito bem, e seu falar assim AA, "a Maria é muito maldosa, ela faz fofoca dos outros, ela fala mal das pessoas..." isso, consegue?

AA Coba...coba

\section{Baleia}


Ent. E se eu falar assim AA, o...que bicho que tá faltando... se eu falar "a Maria, a Maria é muito gorda, olha, parece uma..."

AA (incompreensível)

Ent. Parece um porco? Pode ser também, e se fosse... (o sujeito aponta para a figura da baleia) pode ser essa daí também lembra o nome dessa daí? Nossa, a Maria é muito gorda, ela é uma...?

AA Bala...bala...baleia.

\section{Tartaruga}

Ent. “O João não toma banho, nossa o João é fedido, o João é um..." não? Tudo bem. Deixa eu tirar isso daqui. Se eu falar assim AA, a Maria, é muito lenta, nossa ela é devagar quase parando essa menina, isso, ela é uma...?

AA É...tartarua.

\section{Burro}

Ent. Isso, tartaruga. E se eu falar assim "O João não é muito inteligente não, o João é meio bobo".

AA Buo...burro.

Ao analisar a segunda parte do protocolo de linguagem não-literal desse sujeito, no entanto, podemos ver claramente como a falta de contextualização prejudicou sua compreensão. Mesmo com as opções de significado, quatro dos nomes apresentados não puderam ser definidos, ou seja, o sujeito não conseguiu atribuir sentido à metáfora mesmo tendo três opções de significado. Por exemplo:

Ent. Muito bem, continuando. Hoje tá o dia do telefone, né, AA? Vamos lá, que que a gente parou... ah, no gato. "O João é um gato", eu quero dizer que o João é bonito, eu quero dizer que o João é rico, ou eu quero dizer que o João é honesto? "O João é um gato". Não? Tudo bem, vamos pular. E se eu disser, AA, "O João é um touro. Nossa, o João é um touro"... 


\begin{tabular}{ll}
\hline Animal & Resposta do paciente \\
\hline "O João é um elefante" & - \\
"O João é um cavalo" & - \\
"O João é um gato" & - \\
"O João é um touro" & - \\
"A Maria é uma girafa" & alta \\
"A Maria é uma cobra" & maldosa \\
"O João é um burro" & pouco inteligente \\
"A Maria é uma baleia" & gorda/perigosa \\
"O João é um porco" & sujo \\
"A Maria é uma tartaruga" & lenta \\
\hline
\end{tabular}

Tabela 11.2: Definição de metáforas do sujeito AA (com ajuda)

AA Tou...to...

Ent. Um touro. Mas o que que eu quero dizer com isso?

AA (incompreensível)

Ent. Vou te dar as opções. Eu quero dizer que o João é engraçado, quero dizer que o João é alegre, ou quero dizer que o João é forte? "O João é um touro" quer dizer que o João é engraçado, ou que ele é alegre, ou que ele é forte?

AA (o sujeito tenta olhar as anotações)

Ent. Cê consegue ler AA? Se cê conseguir ler, é esse daqui, ó. "O João é um touro" quer dizer que o João é engraçado, que ele é alegre, ou que ele é forte. Tenta fazer só "sim" ou "não" pra mim então. "O João é um touro" quer dizer que ele é engraçado? Quer? Se eu disser que o João é um touro, quer dizer que ele é alegre? Se eu disser que o João é um touro, quer dizer que ele é forte?

AA (o sujeito fez que sim para todas as opções)

Ent. Os três? (risos) Era pra escolher só um, né AA, mas tudo bem. 


\subsubsection{Sujeito AC}

$\mathrm{O}$ sujeito AC deu respostas interessantes para essa parte da entrevista. Novamente, o contexto foi dado para todas as metáforas, das quais o sujeito só não foi capaz de produzir duas. Um ponto que podemos destacar é que, assim como o sujeito CP, esse sujeito se manteve fiel a respostas dadas anteriormente no teste de nomeação literal. Notamos que esse sujeito ignorou a hierarquia de alguns nomes, como apresentado no capítulo 12. Um dos nomes no qual esse fenômeno ocorreu foi "cobra", que o sujeito nomeou como "serpente". Aqui também, ao invés de utilizar a metáfora "cobra", o sujeito preferiu "jararaca". Vejamos os trechos extraídos da transcrição:

\section{Jararaca, burro, vaca}

Ent. Um burro, ótimo, então esses são os animais. Vou voltar pra falar das metáforas agora então. Seu AC, se eu disser...é... "A Maria é muito maldosa, ela fala mal dos outros pelas costas, ela é falsa, a Maria é uma..."

AC Falsa!

Ent. Mas um desses bichos aqui. Um desses bichos.

AC Ah, um desses bichos, então deixa ver aqui qual que é... uma jararaca.

Ent. Muito bem... uma cobra.

AC Então.

Ent. Isso. Se eu disser assim seu AC, "O João não é muito inteligente, ele é meio bobo, assim, ele não é muito esperto não... J João é um..."

AC Um burro.

Ent. Um burro, muito bem. Se eu disser... "A Maria é muito gorda"...

AC Como é que eu posso falar?

Ent. "A Maria é muito gorda, meu deus, a Maria é uma..."

AC Qual bicho que tem aqui... uma vaca pode-se dizer? 


\section{Bicho-preguiça}

Ent. Ótimo. E se eu disser assim “ Nossa! A Maria é muito lenta, ela é muito devagar essa menina! A Maria é uma..."

AC Tem, tem...um bicho-preguiça!

Para a metáfora "girafa", podemos ver dois momentos: no primeiro a entrevistadora não proveu o contexto necessário para a metáfora:

Ent. Vamo vê? Vamo vê, então tá bom. Então olha só, pra começar bem hein, seu AC se eu falar assim "A Maria é muito alta", a Maria é uma...

AC Víbora.

Ent. Víbora é alta?

AC (risos) Não, não, não...é... ai ai ai eu sei como é que fala... mas...

Ent. Não tem problema, pensa um pouquinho, fica calmo, respira... "Nossa, a Maria é muito alta, a Maria é uma..."

AC Meu Deus do céu... eu sei como que p... eu sei como que fala esse negócio aí, mai... ai ai ai ai...hum... ai ca...é que nem o...o jogador de basquete lá...

Ent. Isso... que de alto que a pessoa é, parece uma...é uma...

AC Hum...como é que eu posso falar...?

Ent. Era bem aquela que o senhor tava falando que era difícil.

AC Hãn...

Ent. Não? Vamo, eu vou dar um tempo depois eu pergunto de novo.

Já num segundo momento, com o contexto devidamente apresentado, a resposta foi dada com sucesso:

\section{Girafa}


Ent. Vou voltar praquele lá que o senhor não tinha conseguido falar. "A Maria é muito alta".

AC Ah...ah...ah... ela tem o negócio, ela tem o negócio aqui, mas não consigo lembrar!

Ent. Não, o senhor quer respirar um pouquinho, porque o aconteceu da outra vez, eu saí e o senhor falou "ah é aquilo". Respira. "A Maria é muito alta... olha a cabeça dela vai lá em cima”.

AC Tem tem, tem a palavra, mas num... mas tá difícil.

Ent. Se eu mostrar o bicho o senhor consegue apontar, será? Vou colocar...

AC $\mathrm{O}$ coiso aqui. Esse aqui.

Ent. Esse aqui. Não lembra?

AC (risos) Ah... isso... fugiu...

Ent. Fugiu?

AC Não, eu vou lembrar...girafa!

Quanto à compreensão, esse sujeito também manteve outra característica observada em seu discurso anteriormente. Vimos no capítulo 12 que a perseveração é uma das características do discurso desse sujeito, e na análise da compreensão das metáforas tivemos essa confirmação. $\mathrm{O}$ sujeito não soube dizer o significado das sentenças em contexto não-literal, e escolheu uma das respostas para definir todas as demais:

Ent. Muito bem, seu AC, eu vou dizer a frase e o senhor diz pra mim o que que o senhor entende quando eu falo essa frase, tá? Então vamo lá, "O João é um elefante", que que eu to dizendo que o João é?

AC Se falar elefante...não posso falar elefante né.

Ent. É...não...é a metáfora, que nem se falar "A Maria é uma flor" o senhor entende que ela é bonita, que ela é delicada, que ela é perfumada...

AC Uma gata né? 
Ent. É que ela é uma gata também. Uma gata. Então se eu disser que o João é um elefante eu to dizendo que o João é o quê? Que que tem em comum o João e o elefante pra eu chamar o João de elefante?

AC Tem, em, mas aí é que tá... num num...

Ent. Num vai?

AC Num vai...

Ent. O senhor já ouviu essa frase antes?

AC Claro que eu já vi.

Ent. Hum hum. O senhor não consegue falar, mas o senhor sabe o que é?

AC Ah...é que nem a girafa aí...

Ent. Hum hum.

AC Eu queria... eu queria ter o nome dela no papel pra mim...

Ent. Pro senhor lembrar?

AC É.

Ent. A gente escreve depois então. (risos) Vou pular esse aqui então, depois eu volto. Tá bom?

AC Filha da mãe. O João. O João. (risos)

Ent. O João. (risos)

AC Tá que nem o Agripino, meu genro... disgranhento.

Ent. (risos) Seu genro, sua nora... se eu disser assim seu AC “O João é um cavalo"

AC É um burro também.

Ent. Mas sem ser nome de bicho agora, agora eu digo o nome de bicho o senhor me diz o que que ele faz. "Nossa, o João é um cavalo!".

AC Ah...tá difícil. 
Ent. Difícil de falar? Vou pular então e fazer mais outra. Se eu disser "O João é um gato"?

AC Um gato...é que nem o burro aí. É um gato, como é que eu posso falar que o João é um gato? Não posso falar que é um gato. É uma gata?

Ent. Eu posso falar "A Maria é uma gata” também. "Nossa, a Maria é uma gata!"

AC É, também, aí...

Ent. Tô querendo dizer que ela é o quê?

AC Uma... uma bela mulher.

Ent. Muito bem. Ela é bonita, ótimo.

AC O João também é um belo... belo...

Ent. Um belo homem.

AC Um belo homem!

Ent. (risos) É.

AC Posso falar.

Ent. Pode. Tá ótimo. Então vamo lá, mais um, se eu disser, seu AC, “O João é um touro"...

AC Ah...coitado do homem...

Ent. (risos) Que que o senhor entende se eu falar "O João é um touro"?

AC Ah...tudo ao contrário do negócio aí... não é difícil?

Ent. É difícil, por isso que eu to perguntando, se fosse fácil...

AC “O João é um touro"... “O João é um touro"... tem, tem coisa que a gente possa falar do touro, mas o que, o que que é?

Ent. O que que é? O que que é que chama mais atenção se eu falar "O João é um touro" 
AC O João é um boi?

Ent. Pode ser, mas o que que é, como é que é o boi que eu to comparando o João com o boi? "Nossa, o João é um boi".

AC Não sei.

Ent. Não? Vamo pular então. E se eu disser "A Maria é uma girafa”?

AC É...uma girafa...é uma bela mulher!

Ent. A girafa é bonita?

AC É. Pra mim é bonita!

Ent. Hum hum, mas se eu falar "A Maria é uma girafa” o senhor vai pensar que ela é bonita?

AC E por que n...e por que não?

Ent. Não, não to dizendo que não, só to perguntando se é isso mesmo.

AC Pra mim é hã... uma girafa!

Ent. Hum hum.

AC Pra mim, ela é uma bonita como se fosse uma mulher bonita.

Ent. Hum hum.

AC Entendeu?

Ent. Entendi. Vamo lá.

AC Ela é como uma girafa. Sei lá do que que é, se é isso mesmo.

Ent. Tudo bem, depois a gente volta. Se eu disse seu AC "A Maria é uma cobra".

AC Nossa senhora.

Ent. Que que eu tô dizendo da Maria?

AC Uma bela, uma bela de uma mulher. Uma bela mulher. 
Ent. Ela é bela, ela é bonita também?

AC Bonita também.

Ent. Tá bom. Se eu disser "O João é um burro"?

AC Coitado do...(risos) coitado do... do... João...tá... tudo a gente tá...

Ent. Só tá levando né? (risos)

AC Tá sendo vítima né? Ai ai ai ai... "O João é um burro”... tem tanta coisa pra... burro...burro... A minha barriga tá...

Ent. Tá com fome seu AC?

AC Não, não to com fome, a minha barriga que é assim mesmo.

Ent. "Nossa o João é um burro".

AC Não sei.

Ent. Não?

AC Tá difícil.

Ent. Vamo pulá. Se eu disser, seu AC, “a Maria é uma baleia”?

AC Coitada da Maria. Coitada da Maria.

Ent. "Nossa, Maria você é uma baleia"

AC Eu vou falar pra ela, Maria, que você é uma baleia!

Ent. (risos) Que que quer dizer isso, “a Maria é uma baleia”?

AC Tem, tem tanta coisa de... tanta coisa bonita pra falar da Maria...

Ent. Da Maria, vai chamar ela de baleia? (risos)

AC Da Maria!

Ent. (risos) Mas é só pra eu saber se o senhor tá sabendo usar os nomes de animais desse jeito. 
AC Tem...tanta coisa bonita que a gente pode falar... e não vem! E não vem! Eu vou... a hora que eu chegar em casa eu vou meter o couro na (incompreensível)...

Ent. Tudo bem, vamo pulá então...

AC ... Vou falar pra ela "Vocês... você me culpou de tanta coisa na v... na vi... na minha vida né?".

Ent. Quem fez isso?

AC Vou falar pra Maria!

Ent. (risos) Coitadinha da Maria!

AC Eu tenho uma Maria lá em casa.

Ent. O senhor tem uma Maria? Quem é?

AC A minha nora.

Ent. A sua nora é a Maria? Tadinha da Maria...

AC (risos)

Ent. Não vá falar pra ela que eu chamei ela de baleia...

AC (risos)

Ent. Última coisa... não, mais uma coisa pra ver com o senhor ainda, seu $\mathrm{AC}$, "O João é um porco".

AC Puta que o pariu. O João... coitado do João, tá na área...

Ent. (risos)

AC Ah... não tem... não tem coisa mais bonita pra você falar do João é um porco?

Ent. Eu vou... eu vou dar uma pista pro senhor, eu to vendo como que o senhor consegue fazer sem pista, depois eu tento com pista. É... e se eu disser, última coisa, "A Maria é uma tartaruga"?

AC Nossa...cê...cê... coisa bonita! 
Ent. (risos)

AC Tanta coisa!

Ent. Mas tem que ser os nomes de bicho, seu AC! Como é que eu vou fazer? O gato ainda foi bonito, mas os outros não são. E eu preciso saber como que o senhor tá fazendo pra lembrar os nomes dos bichos. "A Maria é uma tartaruga".

AC Olha Maria, você é uma tartaruga fora d'água tá?

Ent. Isso, o que que quer dizer?

AC Fora d'água... ela é uma fora d'água, ela não é uma tartaruga, uma...é uma coisa fora d'água.

Ent. Um peixe fora d'água?

AC Bela.

Ent. Hum, pode ser?

AC Então. Bela. Maravilhosa. Entendeu?

Mesmo quando o sujeito foi ajudado pelas opções de resposta, apenas metade das respostas foram as esperadas, como podemos ver na tabela 10.3 .

\subsubsection{Sujeito DP}

Os demais sujeitos apresentaram resultados menos conclusivos. O sujeito DP conseguiu produzir e definir quase todas as metáforas (com exceção da produção da metáfora "cavalo"). O único ponto que podemos ressaltar é que o sujeito não conseguiu lembrar do nome "baleia" em situação literal, aparentemente confundido "baleia" com "tubarão", mesmo com insistência da entrevistadora:

\section{Primeira tentativa:}

Ent. Muito bem. (mostra a figura de uma baleia) 


\begin{tabular}{ll}
\hline Animal & Resposta do paciente \\
\hline "O João é um elefante" & gordo \\
"O João é um cavalo" & grosso \\
"O João é um gato" & bonito \\
"O João é um touro" & altaçado \\
"A Maria é uma girafa" & pobre \\
"A Maria é uma cobra" & ciumento \\
"O João é um burro" & mal intencionada \\
"A Maria é uma baleia" & sujo \\
"O João é um porco" & pobre \\
\hline
\end{tabular}

Tabela 11.3: Definição de metáforas do sujeito AC (com ajuda)

DP Ah, esse daí é o... como é que chama... não é golfinho é o...é o outro. Tá vendo, não é assim...

Ent. Não é assim né...

DP Não é assim, como você tá pensando.

Ent. Mas a senhora tá ótima.

DP É... ai meu deus! Eu vou lembrar! Depois.

Ent. Depois? Então vou deixar ela aqui.

DP Agora eu não lembro, não olho...

\section{Segunda tentativa:}

Ent. Agora a gente vai voltar praquele lá que a senhora não lembrou.(mostra a figura de uma baleia)

DP Ai, como é que é...humm...

Ent. Mas a senhora sabe qual que é e só não lembra o nome.

DP Não, eu sei qual que é, eu sempre compro peixe aí o meu marido fala "esse daí é..." é do mar... não lembro. 
Ent. Mas esse não é aquele que morde.

DP É, esse é.

Ent. Não, esse daqui não era pra ser esse, não. Esse era pra ser o outro que é mais bonzinho.

DP Ah, então é o peixe, comum.

Ent. Comum não.

DP Não é... tem o golfinho, não é né? É golfinho, não é?...

Ent. Baleia.

DP Baleia. Mas a baleia morde.

Ent. Morde?

DP Morde.

Ent. É que eu pensei que a senhora tava pensando em tubarão.

DP Não, não, baleia.

Ent. Porque a senhora falou que vai na feira e tal, porque tem gente que compra...

DP Não a gente compra aquela... aquela...é... aquele pedaço do peixe que o meu marido fala "isso daí é tubarão".

Ent. É. Cação, né?

DP É, cação.

Mas a metáfora "baleia" foi produzida com sucesso:

Ent. Burro. Se eu disse "a Maria é muito gorda”...

DP Gorda, já falou, elefante.

Ent. Eu falei “o João é um elefante” agora a Maria é uma...

DP Baleia.

Devemos ressaltar, no entanto, que esse sujeito apresentou pouquíssimos prejuízos de linguagem, concluímos que a linguagem não-literal não sofreu danos. 


\begin{tabular}{ll}
\hline Animal & Resposta do paciente \\
\hline "O João é um elefante" & gordo \\
"O João é um cavalo" & malcriado \\
"O João é um gato" & bonito \\
"O João é um touro" & grande, forte \\
"A Maria é uma girafa" & alta \\
"A Maria é uma cobra" & fofoqueira \\
"O João é um burro" & não sabe nada, idiota \\
"A Maria é uma baleia" & gorda \\
"O João é um porco" & sujo \\
"A Maria é uma tartaruga" & devagar \\
\hline
\end{tabular}

Tabela 11.4: Definição de metáforas do sujeito DP

\subsubsection{Sujeito SR}

O mesmo podemos dizer do sujeito SR, que produziu algumas parafasias no discurso literal, mas no uso da linguagem não-literal, definiu e produziu as metáforas também sem maiores problemas, com poucas excessões. Vimos no capítulo 5 que o acesso lexical envolve essencialmente o reconhecimento dos predicados principais de um conceito e descobrir qual é o lema único que as possui como condições especiais. Nos exemplos a seguir, podemos ver que esse sujeito apresentou uma dificuldade discreta na compreensão de duas metáforas: elefante e cobra. Para a primeira, o sujeito afirmou que o significado seria "grande" e não "gordo". Essa seria uma resposta aceitável, mas mesmo quando a entrevistadora deu outras opções de resposta, o sujeito afirmou que não entenderia a sentença "O João é um elefante" como "o João é gordo". Apesar de o significado sugerido pelo sujeito ser aproximado, acreditamos que isso seja um indício de que o significado principal da metáfora "elefante" não tenha sido alcançado. Isso pode ser confirmado pela resposta do sujeito para o significado de "cobra" que também nos parece aproximado, mas não exato.

\section{Elefante}

Ent. Hum hum, é verdade... deixa eu dar as opções que eu tenho aqui pro senhor. "Grande" encaixa também, mas vamos ver. O senhor 
entenderia que o João é gordo, que o João é desleixado, ou que o João é invejoso?

SR Repete tudo...tudo de novo.

Ent. Vou repetir. Se eu disser "nossa, o João é um elefante", o senhor entende que eu to falando que o João é gordo, que o João é desleixado, é largado, ou que o João é invejoso?

SR Não, não...é eu tendi que ele...não é nenhuma dessas coisas, não entendia nenhuma dessas coisas.

Ent. Sério? Se eu dissesse isso pro senhor ia parecer mais que ele é bravo ou que ele é alto?

SR Isso, é.

Ent. Se eu disser pro senhor que o João é um elefante o senhor não entende que ele é gordo?

SR Não.

Ent. Tá legal.

SR Mas eu, eu a... eu pego a gordura do porco, muito mais gordo, mas pode ser uma baleia, um boi. Mas o boi é... carestiza força né? Faz um pouco fora.

Cobra E se eu disser "a Maria é muito alta”... ah não, desculpa, essa pergunta eu já fiz, vou pular essa e fazer ela depois então, se eu disser pro senhor... "a Maria é uma cobra”?

SR É muito brava.

Ent. Muito brava?

SR É.

Ent. Hum hum, muito bem. O senhor não entenderia que ela é maldosa?

SR Não.

Ent. Que ela é brava?

SR É. 


\begin{tabular}{ll}
\hline Animal & Resposta do paciente \\
\hline "O João é muito gordo" & porco \\
"O João é muito grosso" & cavalo \\
"O João é muito bonito" & pão, gato \\
"O João é muito forte" & cavalo de corrida \\
"A Maria é muito alta" & girafa \\
"A Maria é muito maldosa" & cachorra \\
"O João não é muito inteligente" & burro \\
"A Maria é muito gorda" & baleia \\
"O João é muito sujo" & porco \\
"A Maria é muito lenta" & lesma \\
\hline
\end{tabular}

Tabela 11.5: Produção de metáforas do sujeito SR

\begin{tabular}{ll}
\hline Animal & Resposta do paciente \\
\hline "O João é um elefante" & muito grande \\
"O João é um cavalo" & muito bruto, muito forte, grande \\
"O João é um gato" & bonito \\
"O João é um touro" & forte \\
"A Maria é uma girafa" & muito alta \\
"A Maria é uma cobra" & muito brava \\
"O João é um burro" & pouco inteligente \\
"A Maria é uma baleia" & $\begin{array}{l}\text { gorda } \\
\text { "O João é um porco" }\end{array}$ \\
"A Maria é uma tartaruga" & muito devagar, bicho preguiça \\
\hline
\end{tabular}

Tabela 11.6: Definição de metáforas do sujeito SR 


\subsubsection{Sujeito JN}

Por último, o sujeito JN, que parece apresentar a dificuldade de acesso lexical mais severa dentre esses sujeitos, apresentou prejuízos severos tanto para a produção de nomes em contexto literal e não-literal, mas a sua compreensão, ao menos com a ajuda das opções, foi razoavelmente satisfatória. O que nos faz acreditar que no que concerne esta pesquisa, o seu tipo de afasia difere das dos demais sujeitos. Um ponto que podemos destacar se deu no momento da tentativa de compreensão da metáfora "gato". O sujeito afirmou não conseguir explicar o que a metáfora significava, porém, quando a entrevistadora mudou o gênero do sujeito, a compreensão foi imediata. Vejamos alguns recortes:

\section{Produção:}

Ent. Não tem problema. Vamo pro próximo. Seu JN, se eu falar assim “O João é muito bonito, o João é lindo"...

JN Ainda, ainda parece que já... (risos)

Ent. (risos) Aí já é uma coisa boa né, de se dizer de uma pessoa...

\section{JN É!}

Ent. "O João é lindo, o João é muito bonito, o João é um..."

JN Po...hum...num tem jeito de falar meu deus, por quê? Por quê?

Ent. Isso aqui é difícil seu JN, fica calmo, isso aqui é difícil mesmo, eu tô fazendo pra ver... chutar o balde!

JN Va...hum...

Ent. "como o João é lindo, meu deus, como o João é bonito, o João é um..."

JN Num tem jeito, minha filha, num tem...

Ent. Não? Vou pular pro próximo, vou fazer mais rapidinho pro senhor não ficar sofrendo. Se eu falar "O João é muito forte"

JN Forte...forte, muito forte.

Ent. Forte. 
JN Forte...

Ent. Que animal que eu falo isso, “O João é muito forte, o João é um..."

JN Ca, cach...(risos) não tem jeito.... ca...

Ent. “O João é..."

JN Forte...

Ent. Forte!

JN Forte é... ele...num tem jeito não...

\section{Compreensão:}

Ent. Então tá bom. Se eu disser " O João é um cavalo, nossa, o João é um cavalo!". Eu tô querendo dizer que o João é invejoso, eu tô querendo dizer que o João é grosso, ou eu tô querendo dizer que o João é feio?

JN Gro...grosso.

Ent. Grosso, muito bem.

JN É... mais ou menos, mas foi né!

Ent. É, mas o senhor tá acertando tudo, muito bem, era isso que eu queria saber. Olha só, se eu disser “o João é um gato! O João é um gato!”, eu tô querendo dizer que o João é bonito, que o João é rico ou que o João é honesto?

JN Honesto... honesto...

JN O gato é honesto?

JN Não, é...

JN “O João é um gato”. Bonito, ele é rico ou ele é honesto? Qual desses três? "Nossa, olha o João, o João é um gato!”

JN Num fa...

Ent. Vou falar de novo, não fica nervoso, seu JN! 


\begin{tabular}{ll}
\hline Animal & Resposta do paciente \\
\hline "O João é muito gordo" & - \\
"O João é muito grosso" & "cav" "la" " $v a "$ \\
"O João é muito bonito" & - \\
"O João é muito forte" & "cach" \\
"A Maria é muito alta" & - \\
"A Maria é muito maldosa" & - \\
"O João não é inteligente" & " $b "$ \\
"A Maria é muito gorda" & - \\
"O João é muito sujo" & - \\
"A Maria é muito lenta" & - \\
\hline
\end{tabular}

Tabela 11.7: Produção de metáforas do sujeito JN

JN Mas eu sei, eu quero!

Ent. Eu sei que o senhor quer!

JN Eu sei!

Ent. “Gato, o João é um gato!”, ou melhor, vamos mudar, porque se for a Maria vai ficar melhor pro senhor né?

JN Vai, vai.

Ent. "A Maria é uma gata".

JN Bonita.

Ent. Aaah! Agora sim, era o João que tava atrapalhando! (risos)

JN (risos) Bonita, bonita. 


\begin{tabular}{ll}
\hline Animal & Resposta do paciente \\
\hline "O João é um elefante" & gordo \\
"O João é um cavalo" & grosso \\
"O João é um gato" & - \\
"A Maria é uma gata" & bonita \\
"O João é um touro" & bravo \\
"A Maria é uma girafa" & grande \\
"A Maria é uma cobra" & brava / maldosa \\
"O João é um burro" & não é inteligente \\
"A Maria é uma baleia" & grande \\
"O João é um porco" & sujo \\
"A Maria é uma tartaruga" & pouco inteligente \\
\hline
\end{tabular}

Tabela 11.8: Definição de metáforas do sujeito JN 


\section{Capítulo 12}

\section{Discussão dos resultados}

A proposta desta pesquisa é apresentar dados extraídos de entrevistas com sujeitos afásicos a fim de discutir como a linguagem literal e a linguagem não-literal estariam representadas no léxico mental. A hipótese inicial deste estudo foi verificar se os nomes de animais previamente listados poderiam se comportar de formas diferentes no discurso dos sujeitos de acordo com o contexto em que fossem apresentados (literal ou não-literal).

A escolha das metáforas com nomes de animais não se deu por acaso. Conforme apresentado no capítulo 1 , o primeiro sujeito a participar desta pesquisa apresentou déficit semântico na categoria "animais" e esse não é um acontecimento isolado: segundo Capitani (2003), mais ou menos três quartos dos casos apresentados na literatura de déficits de categorias específicas apresentam maior dificuldade para nomear seres vivos, enquanto um quarto apresenta o padrão contrário. Além disso, as metáforas com esses nomes são bastante frequentes e disseminadas também. Por essas razões, não podemos acreditar que a ativação de um desses nomes em um dos dois contextos apresentados (metafórico ou não-metafórico) tenha ocorrido por simples cristalização do uso apenas.

No decorrer da parte teórica do trabalho, apresentamos diversas teorias que podem contribuir com o embasamento das ideias aqui discutidas. Nos capítulos 2 e 3, vimos como os itens lexicais se ordenam dentro de redes funcionais, e que esses itens não parecem estar relacionados a apenas uma área cerebral específica. Sendo assim, parece razoável imaginar que mesmo que uma área cortical esteja danificada, ainda é possível que alguns itens linguísticos que pareçam (a princípio) estar inacessíveis, estejam ainda alcançáveis dentro do léxico mental se utilizarmos outras vias de acesso. 


\begin{tabular}{lll}
\hline Sujeito & Produção Literal & Produção Metafórica \\
\hline AA & 6 & $\mathbf{8}$ \\
AC & 8 & 8 \\
CP & 5 & $7 \cdot 5$ \\
DP & 9 & $\mathbf{1 0}$ \\
JN & 2 & $1 \cdot 5$ \\
SR & 8 & $\mathbf{1 0}$ \\
\hline
\end{tabular}

Tabela 12.1: Resultado do teste de produção de nomes literais e metáforas: número de acertos por paciente

Uma lesão que prejudique uma porção de neurônios ligada ao acesso a certos itens lexicais, por exemplo, pode afetar a ignição completa desses itens, mas a ativação pode acontecer mesmo com apenas uma fração das características do objeto estando presente no input. Acreditamos que os resultados apresentados aqui sejam um exemplo desse caso. Os sujeitos apresentaram uma melhora discreta no acesso lexical aos nomes de animais quando estes foram relacionados a características semântico-pragmáticas presentes nas metáforas (vide tabela 12.1). Segundo Levelt (1989), certos componentes do léxico mental parecem ser altamente automáticos. Existe muito pouco controle executivo nos procedimentos de formulação e articulação, e as redes funcionais poderiam prover a base para a associação, no sentido psicológico, entre um nome de animal e a imagem visual que a ele se relaciona, ou entre um verbo e a ação que ele expressa. Ligações muito fortes dentro da rede podem ser o motivo pelo qual uma imagem é ativada automaticamente por uma forma de palavra apresentada e que, ao contrário, a imagem quase que automaticamente chama o nome para a memória ativa. Assim, nomes de animais, por exemplo, deveriam vir à mente automaticamente sem qualquer consciência e com muita rapidez. No entanto, a produção dos nomes de animais apresentados em nossas entrevistas trouxe melhores resultados dentro do contexto metafórico do que com a apresentação das figuras, o que nos faz crer que a introdução de um contexto semântico-pragmático colabora com o acesso a esses nomes. 
Produção de nomes em linguagem literal $\times$ não-literal

\subsection{Produção de nomes em linguagem literal $x$ não-literal}

Um dos pontos nos quais se baseia esta pesquisa é a teoria de que as palavras possuem uma única representação fonológica dentro do léxico mental que pode ser sobreposta por diferentes significados, como apresentado no capítulo 4 (Pulvermüller, 2002). Acreditamos que isso pode ser aplicado à questão das metáforas.

Na seção 4.2, explicamos que homófonos são palavras de forma fonológica idêntica que possuem representações semânticas diferentes. No caso das metáforas, no entanto, temos uma situação singular. Os homófonos são representações de palavras atribuídos a conjuntos diferentes de neurônios que se sobrepõem na parte fonológica da área perisilviana, enquanto as metáforas parecem se sobrepor tanto na parte fonológica como também numa parte semântica/pragmática. Neste caso, estamos lidando com polissemias, mas acreditamos que o mesmo padrão possa ser aplicado aqui, ou seja, uma mesma representação fonológica, com significados diferentes. A linguagem não-literal é formada quando fazemos uso de uma palavra e de (pelo menos) um dos seus traços semânticos/pragmáticos a fim de explicar uma coisa em termos de outra. No entanto, não parece haver muito material na literatura neurolinguística sobre relações de significado entre nomes usados como metáfora ou em sentido literal. Os itens lexicais podem estar relacionados com traços de sintaxe, morfologia, significado e forma, segundo Levelt (1989), mas não encontramos nada sobre dois itens lexicais que tenham a mesma forma e compartilhem alguma relação de significado, pragmaticamente falando. Contudo, no capítulo 3, vimos que quando um falante passa pelo processo de aprendizado de uma palavra nova, a atividade correlacionada de neurônios semanticamente relacionados é incluída nas representações neuronais de palavras de contexto já conhecido. Esse processo, em conjunto com a rede fonológica da palavra recém-incluída, podem permitir o aprendizado do seu significado. Claramente, isso significa que neurônios relacionados semanticamente serão compartilhados entre palavras previamente conhecidas e palavras novas, de forma que as suas representações neuronais se sobreporiam em suas partes semânticas. Essa linha de pensamento mostra que o aprendizado do significado de uma palavra baseado na atividade neuronal correlacionada não é restrita ao cenário palavra-objeto. 
Produção de nomes em linguagem literal $\times$ não-literal

Mencionamos anteriormente ${ }^{1}$ que as discussões teóricas para definir se o problema reside nas próprias representações semânticas ou no acesso às mesmas é assunto para as abordagens terapêuticas utilizadas na reabilitação da afasia. Ou seja, é possível que a dificuldade para nomear objetos esteja centrada na degradação do conhecimento semântico, o que significa que os pacientes com essa dificuldade deveriam desenvolver técnicas compensatórias para recuperar os nomes perdidos. No entanto, se o problema estiver apenas no acesso a esses nomes, o sujeito precisaria encontrar a melhor estratégia que permitisse o menor tempo de processamento para chegar ao nome-alvo. Os resultados apresentados aqui sugerem que, no caso desses pacientes, o problema está no acesso.

Para explicar a proposta aqui apresentada, uma das teorias que observaremos é discutida por Caramazza (1997) exemplificando diferentes níveis que devem ser percorridos durante o processo de acesso à uma palavra.

O diagrama apresentado pelo autor, aqui reproduzido (12.1), visa identificar a estrutura das representações lexicais. O modelo distingue três níveis diferentes de representação: o nível conceitual, o nível do lema e o nível do lexema. O nível conceitual representa conceitos lexicais como pontos unitários dentro de uma rede. O significado de uma palavra é dado por um conjunto de conexões entre o conceito de um ponto específico (como TIGRE) e outros pontos da rede. Cada ponto de conceito lexical está conectado a um ponto de lema; os pontos de lema são unidades independentes que estão conectadas a um conjunto de pontos sintáticos especificando suas propriedades gramaticais. Cada ponto de lema está conectado a um ponto de lexema que, através de suas conexões segmentais, especifica a forma ortográfica ou fonológica de uma palavra.

O objetivo do autor durante a discussão do modelo apresentado é revisar os diferentes níveis de processamento no acesso lexical no que diz respeito aos pontos gramaticais, que são fundamentais dentro desse processo. $\mathrm{O}$ objetivo da pesquisa aqui apresentada também é discutir diferentes níveis de processamento, mas não discutiremos as questões sintáticas em si. No entanto, como serve ao nosso propósito, apresentaremos aqui alguns pontos discutidos por Caramazza a fim de traçarmos um paralelo com a nossa própria questão.

Segundo o autor, as teorias de produção do discurso diferem em vários pontos quando se trata do acesso às palavras no momento de produção da

\footnotetext{
${ }^{1}$ Ver seção $1 \cdot 3 \cdot 1$.
} 


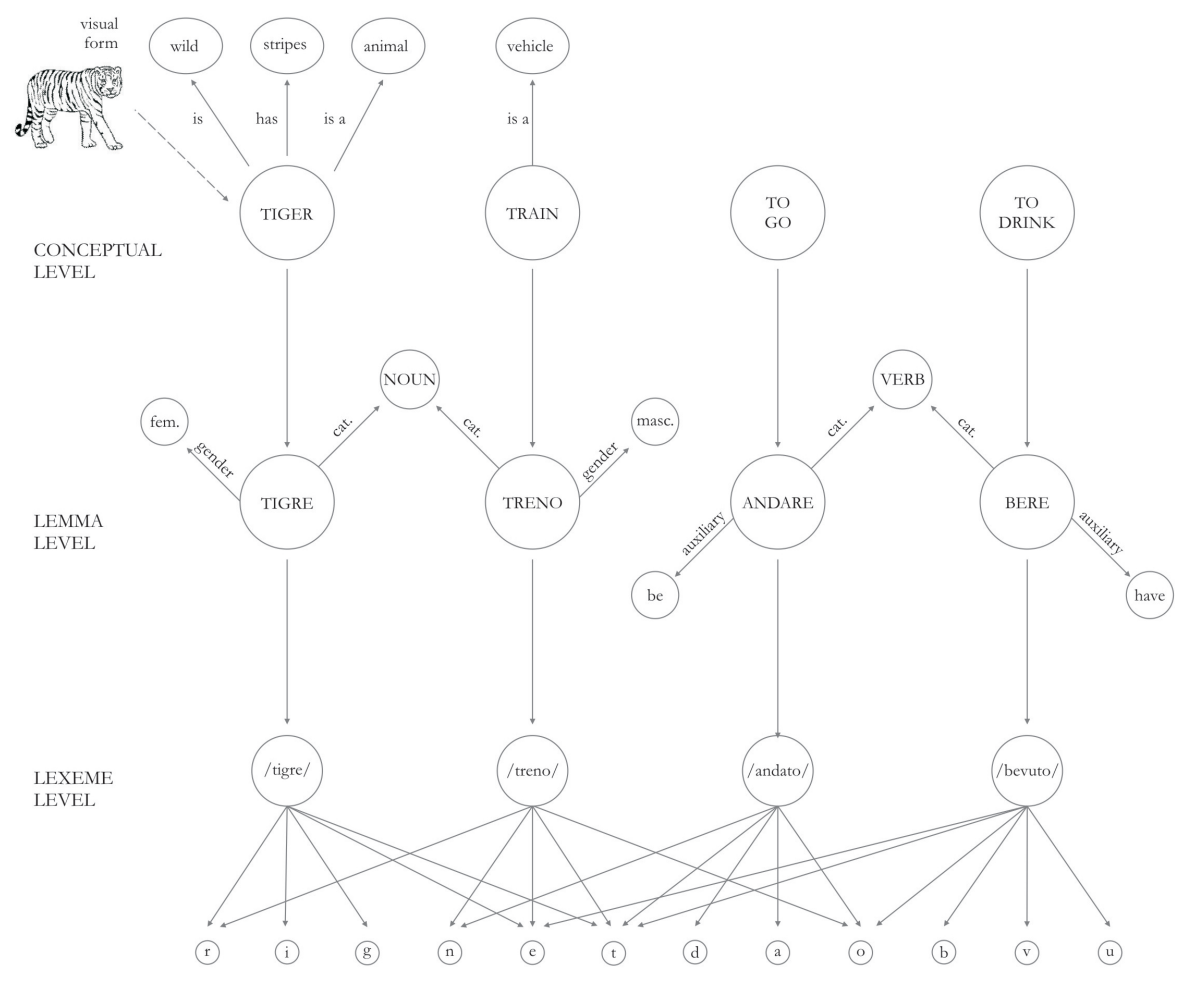

Figura 12.1: Os níveis de acesso lexical. Adaptado de (Jescheniak \& Levelt, 1994); (Roelofs et al., 1996) 
Produção de nomes em linguagem literal $\times$ não-literal

linguagem, porém em dois pontos fundamentais existe concordância: (1) informações sobre as formas sintáticas, semânticas e lexicais constituem níveis independentes de representação e (2) esses níveis de representação são, provavelmente, acessados sequencialmente durante a produção da linguagem. O ponto de vista dominante é que o acesso lexical envolve pelo menos dois estágios distintos de processamento. O primeiro estágio envolve a seleção de uma representação lexical semanticamente e sintaticamente especificada (ou lema); o segundo estágio envolve a seleção da sua representação léxico-fonológica (ou lexema) (Bock (1986); Bock \& Levelt (1994)).

Existem na literatura neurolinguística diversos casos nos quais podemos observar relatos sobre sujeitos afásicos que apresentam dificuldades seletivas na produção da linguagem, como dificuldade para produzir nomes, mas não verbos ou vice-versa. A existência dessas dissociações implica que a informação sintática é uma das dimensões pelas quais o sistema lexical é organizado. Assim, aparentemente, parte da informação sintática é processada separadamente da informação semântica e lexical.

Palavras que são fonologicamente e ortograficamente idênticas, mas são diferentes no que diz respeito ao significado ou à classe gramatical (o autor dá os exemplos "the watch" e "to watch", "the bank" de dinheiro e "the bank" de rio; para o português poderíamos citar os exemplos de "manga" como fruta ou parte de uma roupa, "banco" de dinheiro ou de mobília, "casa" de moradia ou a terceira pessoa do verbo "casar") são casos a serem observados. A diferença dessas palavras não estaria no nível da forma lexical (tal como a entende (Caramazza, 1997)), já que elas são idênticas, mas sim no nível de propriedades semânticas e sintáticas.

O autor também afirma que uma informação particularmente relevante sobre essa questão é a performance de sujeitos com danos cerebrais que apresentam dificuldades na produção de palavras apenas de uma classe gramatical em apenas uma modalidade de saída (Hillis \& Caramazza (1991); Rapp et al. (1997); Rapp et al. (1997)). Por exemplo, um sujeito apresentou severas dificuldades para escrever os verbos que produzia com facilidade oralmente. Em tarefas de produção oral e escrita com homonímias (como "to watch" e "the watch"), ele produziu corretamente tanto a forma verbal como a forma nominal, mas na tarefa escrita ele conseguiu escrever apenas a forma nominal corretamente. Outros exemplos de efeitos de classe gramatical de modalidade específica incluem sujeitos que apresentam uma dupla dissociação de classe gramatical por modalidade. Um dos sujeitos 
Produção de nomes em linguagem literal $\times$ não-literal

entrevistados (Hillis \& Caramazza, 1991) apresentou um déficit seletivo para reconhecer formas escritas de verbos e uma dificuldade seletiva para reconhecer formas orais de nomes. Outro paciente apresentou dificuldade para produzir nomes oralmente e verbos na forma escrita. O que esses casos têm em comum é a surpreendente especificidade da desordem - o déficit envolve palavras de uma classe gramatical específica em apenas uma modalidade de entrada ou de saída (oral ou escrita).

Esse déficits seletivos de classe gramatical, restritos apenas à produção oral ou apenas à produção escrita, reforçam a teoria defendida pelo autor de que o conhecimento sintático é representado independentemente das formas léxico-semânticas ou da forma da palavra. $O$ fato de que o déficit está restrito apenas a uma modalidade de saída implica que o sistema semântico-lexical está intacto. Além do mais, dado que o sistema semânticolexical dos sujeitos dos estudos de Caramazza e colegas está intacto e que os prejuízos estão limitados a apenas uma classe gramatical, podemos dizer que o déficit está ligado apenas ao nível sintático da representação. Portanto, o autor parece estar certo em afirmar que as informações léxicosemânticas e sintáticas são representadas independentemente.

Utilizando os argumentos apresentados acima, esta pesquisa pretende afirmar que uma das explicações possíveis para que haja diferença entre a produção e compreensão de representações lexicais das formas literais e não-literais de algumas palavras é que elas podem ser processadas independentemente. Acreditamos que seja possível que alguns sujeitos anômicos apresentem dificuldade para produzir formas de palavras no seu sentido literal, mas que o mesmo não aconteça quando as mesmas palavras são produzidas no seu sentido não-literal, ou vice-versa, sugerindo que nesses sujeitos o sistema semântico-lexical pode estar mais preservado do que se imagina, sendo que o tipo de entrada ou saída dessas formas lexicais poderia ser o elemento prejudicado.

Observando os resultados do teste da tabela ??, acreditamos que, apesar de haver uma conexão entre os itens lexicais apresentados no que diz respeito à forma lexical e a alguns traços de significado pragmático, as vias utilizadas para acessar esses itens são diferentes. Ou seja, diferentes contextos podem acarretar a produção de um item lexical que de outra forma não seria acessado. 
Análise linguística

\subsection{Análise linguística}

Essa mesma questão pode ser discutida do ponto de vista linguístico, apresentando uma teoria levemente distinta, mas chegando a uma mesma conclusão. Levando em consideração a teoria de Jakobson para a determinação dos diferentes tipos de afasia, analisamos os resultados obtidos aqui levando em consideração o contexto linguístico observado para que eles aconteçam.

No capítulo 7, vimos que, segundo Jakobson (1971), quando se trata da hierarquia fonema, morfema, palavra, sentença, proposição, devemos saber que essa organização não é apenas uma escala quantitativa. A classificação é feita com base em questões qualitativamente e estruturalmente distintas. Cada nível de unidade linguística apresenta uma relação diferente entre código e contexto e essas diferenças geram consequências para os problemas de estrutura linguística e para o estudo da afasia.

Observando o discurso dos sujeitos selecionados para esta pesquisa, acreditamos que eles apresentam relações internas prejudicadas (desordem de similaridade), dado que para esses sujeitos, a maior dificuldade parece estar no acesso lexical e não na dificuldade de combinar os constituentes. Vimos no capítulo 10 que, com exceção dos sujeitos AA e CP, os sujeitos são relativamente fluentes ${ }^{2}$. Segundo Jakobson (1966), se a palavra requisitada estiver fora de contexto, encontrá-la será uma tarefa impossível para o sujeito que sofra desse tipo de afasia. Também segundo Jakobson (1971), afásicos com dificuldades de relação interna apresentam problemas para organizar unidades do código linguístico de acordo com a sua similaridade. Eles seriam capazes de combinar duas unidades dentro de uma mensagem, mas não de substituir uma unidade por outra com base na sua semelhança mútua. Essa relação de similaridade e contraste, afetada na linguagem desses sujeitos, seria a base da formação das metáforas, e sem ela o sujeito não seria capaz de responder a estímulos metafóricos.

No entanto, nesta pesquisa os sujeitos foram expostos a uma situação singular: por um lado, eles foram requisitados a produzir e compreender metáforas, por outro lado, o contexto (para onde sua atenção estaria focada segundo Jakobson) foi apresentado de forma a facilitar essa tarefa. Ou

\footnotetext{
${ }^{2} \mathrm{O}$ sujeito $\mathrm{CP}$ não é fluente, mas não apresentou sinais significativos de agramatismo. AA, no entanto, se diferencia dos demais. Ele apresenta severas dificuldades de produção de linguagem devido a problemas fono-articulatórios, o que torna difícil a determinação do seu déficit entre afasia motora ou sensorial.
} 
Produção e compreensão

seja, uma vez que o contexto seja dado a esses sujeitos, essa parte do processamento é facilitada, e a tarefa de acessar os itens lexicais torna-se menos problemática.

\subsection{Produção e compreensão}

Durante a análise das entrevistas, encontramos diferenças na habilidade de produção e compreensão de metáforas pelos sujeitos. Acreditamos que essa diferença pode ser explicada coerentemente com a afirmação de que o contexto cooperou com a produção das metáforas pelos sujeitos.

Jakobson divide os processos de codificação e decodificação em duas partes: para o falante, o primeiro passo seria a seleção dos elementos antes de combiná-los em um todo; o segundo estágio seria a construção do contexto. O contrário acontece com a decodificação: o ouvinte primeiramente capta o todo e depois passa para a discriminação dos constituentes. Assim sendo, para os afásicos com déficits de codificação, o contexto seria uma tarefa secundária e, portanto, seria a parte do processamento a causar mais problemas no discurso. Já para os sujeitos com défict de decodificação (que acreditamos ser o caso dos nossos sujeitos), a tarefa secundária seria o acesso aos itens lexicais separadamente, e esta seria a tarefa linguística mais vulnerável.

Para o decodificador, a probabilidade funciona como um recurso linguístico mais útil do que para o codificador. Não existem homonímias para o falante: quando pronuncia a palavra "banco", ele sabe exatamente se está falando do banco como uma peça de mobília ou como instituição financeira, enquanto o ouvinte, contanto que não seja ajudado pelo contexto, deve enfrentar a homonímia e usar um teste de probabilidade.

Podemos ver na parte da entrevista em que os sujeitos tiveram de compreender o uso das metáforas que a falta de contexto prejudicou suas respostas. Quatro dos seis sujeitos precisaram de ajuda para definir o significado das metáforas (com exceção dos sujeitos DP e SR) e mesmo quando as opções de resposta lhes foram dadas eles apresentaram dificuldade para escolher qual se adequaria melhor à situação apresentada. Acreditamos que essa dificuldade é devida à falta de contexto da tarefa: quando os sujeitos tiveram de produzir as metáforas, a entrevistadora proveu o contexto necessário para essa produção, como no exemplo:

Ent. Esse mesmo. “O João não é muito inteligente, não, ele é um..." 
CP Ca-valo, não, não é....eu sei!

Ent. "Nossa, o João é um..."

CP Ai, eu falei... num num é, porque será? Ca-valo... não... porco não... aí esse daqui...

Ent. "Nossa, João, como você é..."

CP Ca-valo...não...

Ent. É ele é parecido com o cavalo, mas é o outro.

CP Porc...não, esse aqui né...

Ent. Esse daí é o porco, é, vou tirar daqui pra não atrapalhar a senhora, ver se você lembra melhor. "Nossa João, como você é..." "Você faz tudo errado, meu deus, como você é..."?

CP Eu sei... ahh... sai... não sai... mas que coisa... burro.

Podemos ver, no entanto, que o mesmo não ocorreu quando a tarefa era compreender as sentenças metafóricas:

Ent. Então, por exemplo, se eu falar assim: “o João é um elefante”, o que eu quero dizer?

CP Hum... por que vai...

Ent. Isso, por que que eu vou chamar ele de elefante? "Nossa, o João é um elefante" eu to querendo dizer o quê, do João?

CP Ah não sei não...

Ent. Não? Vou dar então três opções pra senhora tá? Se eu falar que o João é um elefante eu quero dizer que o João é gordo, que o João é desleixado ou que o João é invejoso?

CP Hum.

Ent. "O João é um elefante", gordo, desleixado ou invejoso?

CP Ah, é! Isso... tão peraí... 
Ent. (risos) Agora a senhora entendeu né?

CP (risos) Eu...eu... mas é muito.

Ent. Quer que eu fale de novo?

CP Pode falar.

Ent. "O João é um elefante" quer dizer que o João é gordo, quer dizer que o João é desleixado ou quer dizer que o João é invejoso?

CP Re... In-vejoso. 


\section{Capítulo 13}

\section{Conclusão}

Nesta pesquisa tentamos demonstrar, com base em entrevistas feitas com seis sujeitos afásicos, que a produção e compreensão de palavras específicas podem ser processadas diferentemente a depender do fato de o contexto em que elas estão inseridas ser literal ou não-literal.

Vimos que os sujeitos participantes desta pesquisa apresentam diferentes tipos de déficits de linguagem, mas é possível concluir que eles se encaixariam no que foi definido por Jakobson como transtorno de seleção ou similaridade, característica principal da afasia sensorial ${ }^{1}$. Todos os sujeitos apresentaram alguma dificuldade de nomeação dos animais quando seus nomes foram apresentados em contexto literal, de modo que podemos afirmar que em todos podemos encontrar dificuldades de acesso lexical, tema principal desta pesquisa.

Para o desenvolvimento desta pesquisa utilizamos como base teórica tanto uma bibliografia focada em questões neuroanatômicas quanto neurolinguísticas. Acreditamos que, para a abordagem desse assunto, as duas áreas se complementam, não podendo uma ser tratada sem a interferência da outra. Com os resultados obtidos aqui, parece-nos que ambas as áreas têm subsídios para explicar os fenômenos observados, mas a utilização das duas em conjunto pode reforçar as conclusões obtidas.

Vimos nos capítulos relacionados a estudos clínicos que os itens lexicais se ordenam dentro de redes funcionais, cujos neurônios são fortemente conectados. Vimos também que a ativação desses neurônios se faz necessária para a representação perfeita desse item lexical, mas que a ativação parcial

\footnotetext{
${ }^{1}$ Lembramos que o tipo de afasia do sujeito AA não pôde ser classificado nos termos de Jakobson devido aos seus déficits articulatórios.
} 
desse grupo também pode levar à representação de tal item. Além disso, no capítulo 3, afirmamos que o uso de palavras em determinados contextos leva a associações entre neurônios nas áreas corticais da linguagem, as chamadas redes de palavras. Isso acrescentado às informações apresentadas nos capítulos 4 e sobre a sobreposição de palavras com áreas fonológicas idênticas e áreas semânticas distintas, bem como as informações no capítulo 5 sobre como o acesso lexical envolve o reconhecimento dos predicados principais de um conceito (e descobrir qual é o lema único que as possui como condições essenciais), oferece a base neurológica para afirmar que é possível e plausível que itens lexicais sejam processados diferentemente se houver diferença no contexto apresentado, como no protocolo aplicado nesta pesquisa.

Essa afirmação pode ser confirmada a partir das contribuições de Jakobson. No capítulo 8 apresentamos uma visão geral das ideias desse autor, juntamente com a definição de cada transtorno de linguagem definido por ele. Algumas dessas definições são altamente específicas e não pudemos classificar os sujeitos desta pesquisa com tamanha riqueza de detalhes baseando-nos apenas nas entrevistas apresentadas aqui. Concluímos, portanto, como afirmado anteriormente, que acreditamos que os sujeitos sofram do chamado transtorno de seleção / similaridade. De qualquer modo, o que importa é ressaltar que a teoria de Jakobson tem como característica principal a oposição entre os eixos metafóricos e metonímicos da linguagem que, de acordo com ele, estão na base dos transtornos de seleção / similaridade e combinação / contiguidade, respectivamente. Nossos sujeitos, portanto, deveriam apresentar dificuldades para a produção e compreensão de metáforas, mas vimos que não foi o que ocorreu: quando ajudados pelo contexto fornecido para a produção das metáforas, os sujeitos apresentaram resultados surpreendentes. Já na tarefa de compreensão das metáforas (o que deveria ser um desafio duplo para os sujeitos pois, ainda seguindo Jakobson, teriam mais dificuldade de compreensão em geral), vimos que a falta de contexto parece ter prejudicado a habilidade dos sujeitos.

A habilidade de compreensão de metáforas dos sujeitos parece mais prejudicada do que a habilidade de produção. Segundo Van Dijk (1977), ainda que as condições pragmáticas tenham uma base cognitiva, devemos lembrar que uma teoria pragmática da linguagem deve fazer uma ponte entre a enunciação e a interação. Isso quer dizer que o que um determinado falante sabe, pensa ou quer durante um ato de fala é menos relevante 
quando se leva em conta a interpretação de seu comportamento. Devemos lembrar, portanto, que os sujeitos foram submetidos a uma entrevista guiada, na qual lhes foi pedido que fizessem inferências metalinguísticas sobre uma determinada característica da linguagem. É possível interpretarmos que os sujeitos apresentam uma dificuldade de abstração dessa situação fabricada para uma situação real, que seria mais facilmente processada por ser envolvida em um frame ${ }^{2}$.

Por esse motivo, levamos em consideração também os momentos de fala espontânea dos sujeitos. Segundo Morato (2010), se adotarmos uma perspectiva neurolinguística sociocognitiva, a pergunta sobre a cognição se torna não uma indagação direta sobre a relação linguagem-mundo, mas sim sobre como nós usamos a linguagem enquanto forma constitutiva de mediação dessa relação. Numa pesquisa que trata de metáforas, que são elementos da linguagem fortemente dependentes dessa mediação, não poderíamos ignorar essa perspectiva. Acreditamos que a alteração da capacidade de realizar operações metalinguísticas é um fator a ser observado na linguagem dos sujeitos afásicos a fim de delimitar problemas de linguagem específicos e teorizar a respeito de questões específicas da linguagem. Contudo, acreditamos que levando em consideração aspectos socioculturais da linguagem e observando a fala espontânea dos sujeitos podemos articular teorias mais completas a respeito da linguagem e da interação.

\footnotetext{
${ }^{2}$ Frames, segundo Van Dijk, são unidades de conhecimento organizadas ao redor de um conceito. Essas unidades contêm as informações essenciais, típicas e possíveis de serem associadas com um determinado contexto. Esse critério discrimina certos episódios de interação, como ir ao cinema, viajar de trem etc.
} 


\section{Referências Bibliográficas}

Berndt, R., A., Caramazza \& Zurif, E. Language functions and brain organization. Academic Pr, 1983.

Blasko, Connine C., D. "Effects of familiarity and aptness on metaphor processing." Journal Exp Psychol Learn Mem Cogn, vol. 19, 295-308, 1993.

Bock, J.K. "Syntactic persistence in language production* 1." Cognitive psychology, vol. 18(3), 355-387, 1986.

Bock, Kathryn \& Levelt, Willem. "Language Production: Grammatical Encoding." In: Gernsbacher, M. (Ed.), Handbook of Psycholinguistics, pp. 945-984. Orlando, FL.: Academic Press, 1994.

Braitenberg, V. Cortical architectonics: General and areal. Raven Press (ID), 1978.

Buonomano, D.V. \& Merzenich, M.M. "Cortical plasticity: from synapses to maps." Annual review of neuroscience, vol. 21(1), 149-186, 1998.

Cacciari, Tabossi P., C. "The comprehension of idioms." Journal Mememory and Language, vol. 27, 668-683, 1988.

Capitani, E. et. al. "What are the facts of category specific deficits? a critical review of the clinical evidence." Cognitive Neuropsychology, vol. 20, 213261,2003 .

Caplan, D. Neurolinguistics and linguistic aphasiology: An introduction. Cambridge Univ Pr, 1987.

Caramazza, A. "How many levels of processing are there in lexical access?" Cognitive Neuropsychology, vol. 14(1), 177-208, 1997. 
Cheour, M., Alho, K. et al. "Maturation of mismatch negativity in infants." International Journal of Psychophysiology, vol. 29(2), 217-226, 1998.

Clark, H.H. "Word associations and linguistic theory." In: Lyons, J. (Ed.), New Horizons in Linguistics, vol. 1. Harmondsworth: Pelican, 1970.

Cohen, R., Kelter, S. \& Woll, G. "Analytical competence and language impairment in aphasia* 1." Brain and Language, vol. 10(2), 331-347, 1980.

Damasio, A.R. \& Damasio, H. "Brain and Language." Scientific American, vol. 267(3), 88-95, 1992.

Damasio, AR \& Tranel, D. "Nouns and verbs are retrieved with differently distributed neural systems." Proceedings of the National Academy of Sciences of the United States of America, vol. 9o(11), 4957, 1993.

DAmasio, H. "Neuroanatomical correlates of the aphasias." Acquired aphasia, vol. 5, 45-71, 1991.

Damasio, H., Grabowski, T.J., Tranel, D., Hichwa, R.D. \& Damasio, A.R. "A neural basis for lexical retrieval." Nature, vol. 380(6574), 499-505, 1996.

Diesch, E., Biermann, S. \& Luce, T. "The magnetic mismatch field elicited by words and phonological non-words." NeuroReport, vol. 9(3), 455, 1998.

Elbert, T., Pantev, C., Wienbruch, C., Rockstroh, B. \& Taub, E. "Increased cortical representation of the fingers of the left hand in string players." Science, vol. 270(5234), 305, 1995.

Ellis, A.W. \& Young, A.W. Human cognitive neuropsychology: A textbook with readings. Psychology Press (UK), 1996.

Fiorin, J. "Métaphore et métonymie: Deux processus de construction du discours.", s/ data.

URL http://www.ditl.info/arttest/art8ooo.php

FludeAndrew, W., Brenda, M. \& Kay, J. "Face processing and name retrieval in an anomic aphasic: Names are stored separately from semantic 
information about familiar people* 1." Brain and Cognition, vol. 11(1), $60-72,1989$.

Fromkin, V.A. Speech errors as linguistic evidence. Mouton, 1973.

GaRRETT, M.F. "Syntactic processes in sentence production." New approaches to language mechanisms: A collection of psycholinguistic studies, vol. 4, 133$177,1976$.

Hagoort, P. \& Brown, C.M. "Gender electrified: ERP evidence on the syntactic nature of gender processing." Journal of Psycholinguistic Research, vol. 28(6), 715-728, 1999.

Harley, T.A. "A critique of top-down independent levels models of speech production: Evidence from non-plan-internal speech errors." Cognitive Science: A Multidisciplinary Journal, vol. 8(3), 191-219, 1984.

Невв, D.O. The organization of behavior: A neuropsychological theory. Lawrence Erlbaum, 2002.

Heeschen, C. \& Kolk, H. "Agrammatism and paragrammatism." Aphasio$\log y$, vol. 2(3), 299-302, 1988.

Hillis, A.E. \& Caramazza, A. "Category-specific naming and comprehension impairment: A double dissociation." Brain, vol. 114(5), 2081, 1991.

Humphreys, G.W., Evetr, L.J. \& TAylor, D.E. "Automatic phonological priming in visual word recognition." Memory $\mathcal{E}$ Cognition, vol. 1o(6), 576-590, 1982.

Humphreys, G.W. \& Forde, E.M.E. "Hierarchies, similarity, and interactivity in object recognition:?Category-specific? neuropsychological deficits." Behavioral and Brain Sciences, vol. 24(03), 453-476, 2001.

JaCksOn, J.H. \& TAYLOR, J. Selected writings of John Hughlings Jackson. Staples, 1958.

Jаковsоn, R. "Linguistic types of aphasia." Brain function, vol. 2, 67-91, 1966.

__ "Aphasia as a linguistic topic." Selected writings, vol. 2, 229-238, 1971. 
_. "Towards a linguistic classification of aphasic impairments." Psycholinguistics and Aphasia, vol. 2, 29-50, 1973.

- "Dois aspectos da linguagem e dois tipos de afasia." Linguística e comunica?ão, vol. 1, 34-62, 2003.

Jakobson, R. \& Halle, M. "Fundamentals of language." The Hague: Mouton, 1956.

Jescheniak, J.D. \& Levelt, W.J.M. "Word frequency effects in speech production: Retrieval of syntactic information and of phonological form." Journal of Experimental Psychology: Learning, Memory, and Cognition, vol. $20(4), 824-843,1994$.

Joseph, R. "The neuropsychology of development: Hemispheric laterality, limbic language, and the origin of thought." Journal of Clinical Psychology, vol. $38(1), 4-33,1982$.

KaAs, J.H., Merzenich, M.M. \& Killackey, H.P. "The reorganization of somatosensory cortex following peripheral nerve damage in adult and developing mammals." Annual Review of Neuroscience, vol. 6(1), 325-356, 1983.

Kertesz, A. \& McCabe, P. "Recovery patterns and prognosis in aphasia." Brain, vol. 100(1), 1, 1977.

Kucera, H. \& Francis, W.N. Computational analysis of present-day American English. Brown University Press Providence, RI, 1967.

Kujala, T., Alho, K. \& N

"A

"AT

"ANEN, R. "Cross-modal reorganization of human cortical functions." Trends in Neurosciences, vol. 23(3), 115-120, 2000.

Lakoff, G. \& Johnson, M. Metaphors we live by. Chicago London, 1980.

Landauer, T.K. "Latent semantic analysis: A theory of the psychology of language and mind." Discourse Processes, vol. 27(3), 303-310, 1999.

Levelt, W.J.M. "Monitoring and self-repair in speech* 1." Cognition, vol. 14(1), 41-104, 1983 . 
- Speaking: From intention to articulation. The MIT Press, 1989.

_- "Accessing words in speech production: Stages, processes and representations." Cognition, vol. 42(1-3), 1-22, 1992.

Lumsden, RD \& Locke, JC. "Biological control of damping-off caused by Pythium ultimum and Rhizoctonia solani with Gliocladium virens in soilless mix." Phytopathology, vol. 79(3), 361-366, 1989.

LURIA, AR. The higher cortical functions in humans and their dysfunctions at local brain injury. Moscow: Moscow State University Publishing House, 1962.

Malsburg, C. "Binding in models of perception and brain function." Current Opinion in Neurobiology, vol. 5(4), 520-526, 1995.

Mansur, M., L. e Radanovic. Neurolinguística: princípios para a prática clínica. Edi?ões Inteligentes, 2004.

Marie, P. "Revision de la question de l'aphasie." Sent Med, vol. 26, 2-241, 1906.

Martin, A. \& Caramazza, A. "Neuropsychological and neuroimaging perspectives on conceptual knowledge: an introduction." Cognitive neuropsychology, vol. 20(3), 195-212, 2003.

Martin, et al., A. "Neural correlates of category specifc knowledge." Nature, vol. 379, 649-652, 1996.

Meyer, D.E. \& Schvaneveldt, R.W. "Facilitation in recognizing pairs of words: Evidence of a dependence between retrieval operations." Journal of Experimental Psychology, vol. 9o(2), 227-234, 1971.

Miceli, G., Silveri, M.C., Nocentini, U. \& Caramazza, A. "Patterns of dissociation in comprehension and production of nouns and verbs." Aphasiology, vol. 2(3), 351-358, 1988.

Miller, G. A. "A psychological method to investigate verbal concepts." Journal of Mathematics and Psychology, vol. 6, 169-191, 1969.

Milner, B. "Hemispheric specialization: Scope and limits." The neurosciences, vol. 3, 75-89, 1974. 
Mohr, B. \& Pulvermuller, F. "Redundancy gains and costs in cognitive processing: effects of short stimulus onset asynchronies." JOURNAL OF EXPERIMENTAL PSYCHOLOGY LEARNING MEMORY AND COGNITION, vol. 28(6), 1200-1223, 2002.

Morato, Edwiges Maria. A Semiologia das Afasias: Perspectivas Linguísticas. Cortez Editora, 2010.

Nettleton, J. \& Lesser, R. "Therapy for naming difficulties in aphasia: Application of a cognitive neuropsychological model." Journal of Neurolinguistics, vol. 6(2), 139-157, 1991.

Papagno, C. "Comprehension of metaphors and idioms in patients with alzheimer's disease: A longitudinal study." Brain, vol. 124, 1450, 2001.

Peña-Casanova, MP, J. e Pamies. Reabilitação da afasia e transtornos associados. São Paulo: Manole, 2005.

Peña-Casanova, J. Manual de logopedia. Elsevier España, 2002.

Perani, D., Paulesu, E., Galles, NS, Dupoux, E., Dehaene, S., Bettinardi, V., Cappa, SF, Fazio, F. \& Mehler, J. "The bilingual brain. Proficiency and age of acquisition of the second language." Brain, vol. 121(10), 1841, 1998.

Posner, M.I. \& DiGirolamo, G.J. "Cognitive neuroscience: Origins and promise." Psychological Bulletin, vol. 126(6), 873-889, 2000.

Pulvermüller, Friedemann. The neuroscience of language. Cambridge, 2002.

Pulvermuller, F., Birbaumer, N., Lutzenberger, W. \& Mohr, B. "Highfrequency brain activity: its possible role in attention, perception and language processing." Progress in Neurobiology, vol. 52(5), 427-445, 1997.

Pulvermuller, F., Lutzenberger, W. \& Preissl, H. "Nouns and verbs in the intact brain: Evidence from event-related potentials and high-frequency cortical responses." Cerebral Cortex, vol. 9(5), 497, 1999.

Rapp, B., Benzing, L. \& Caramazza, A. "The autonomy of lexical orthography." Cognitive Neuropsychology, vol. 14(1), 71-104, 1997. 
Regier, D.A., Narrow, W.E., Rae, D.S., Manderscheid, R.W., Locke, B.Z. \& GoodwIn, F.K. "The de facto US mental and addictive disorders service system: Epidemiologic Catchment Area prospective 1-year prevalence rates of disorders and services." Archives of General Psychiatry, vol. 50(2), 85,1993 .

Roelofs, A., Meyer, A.S. \& Levelt, W.J.M. "Interaction between semantic and orthographic factors in conceptually driven naming: Comment on Starreveld and La Heij (1995)." JOURNAL OF EXPERIMENTAL PSYCHOLOGY LEARNING MEMORY AND COGNITION, vol. 22, 246$251,1996$.

RugG, M.D. "Further study of the electrophysiological correlates of lexical decision." Brain and Language, vol. 19(1), 142-152, 1983.

Saffran, J.R., Aslin, R.N. \& Newport, E.L. "Statistical learning by 8-monthold infants." Science, vol. 274(5294), 1926, 1996.

Schumann, J.H. "2 A neurobiological perspective on affect and methodology in second language learning." Affect in language learning, vol. 4, 28, 1999.

Shannon, C.E. "A mathematical theory of communication." ACM SIGMOBILE Mobile Computing and Communications Review, vol. 5(1), 3-55, 2001.

Silverman, K., Wong, C.J., Higgins, S.T., Brooner, R.K., Montoya, I.D., Contoreggi, C., Umbricht-Schneiter, A., Schuster, C.R. \& Preston, K.L. "Increasing opiate abstinence through voucher-based reinforcement therapy." Drug and Alcohol Dependence, vol. 41(2), 157-165, 1996.

Siviero, M. Capacidade de Abstra?ão e o Teste de Provérbios. Master's thesis, Universidade de São Paulo, 1997.

Smith, E.E. \& Medin, D.L. Categories and concepts. Harvard University Press Cambridge, MA, 1981.

Sommer, F.T. \& PALM, G. "Improved bidirectional retrieval of sparse patterns stored by Hebbian learning." Neural Networks, vol. 12(2), 281-297, 1999 . 
Seuire, L.R. \& Butters, N. Neuropsychology of memory. The Gilford Press, 1984 .

Sterr, A., Muller, M.M., Elbert, T., Rockstroh, B., Pantev, C. \& Taub, E. "Perceptual correlates of changes in cortical representation of fingers in blind multifinger Braille readers." Journal of Neuroscience, vol. 18(11), 4417,1998 .

Swinney, D.A. \& Cutler, A. "The access and processing of idiomatic expressions." Journal of verbal learning and verbal behavior, vol. 18(5), 523-534, 1979.

Tallon-Baudry, C., Kreiter, A. \& Bertrand, O. "Sustained and transient oscillatory responses in the gamma and beta bands in a visual short-term memory task in humans." Visual Neuroscience, vol. 16(03), 449-459, 1999.

VAN DijK, T.A. "Context and cognition: Knowledge frames and speech act comprehension* 1." Journal of Pragmatics, vol. 1(3), 211-231, 1977.

Warrington, E.K. \& McCarthy, R. "Category specific access dysphasia." Brain, vol. 106(4), 859, 1983.

Warrington, E.K. \& Shallice, T. "Category specific semantic impairments." Brain, vol. 107(3), 829, 1984.

Wittgenstein, L. Philosophical Investigations translated by GEM Anscombe. Blackwell, 1974. 


\section{Anexos}




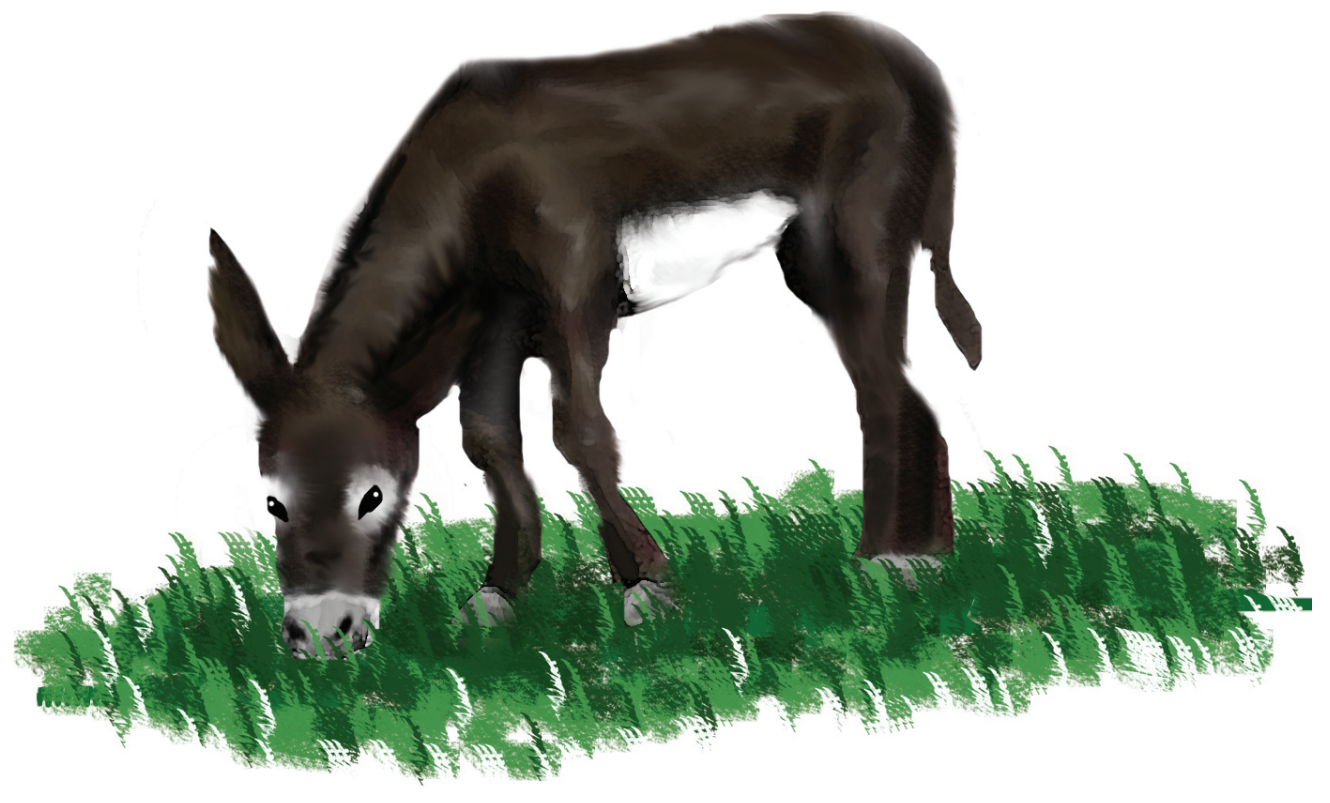

Figura 13.1: Um burro 


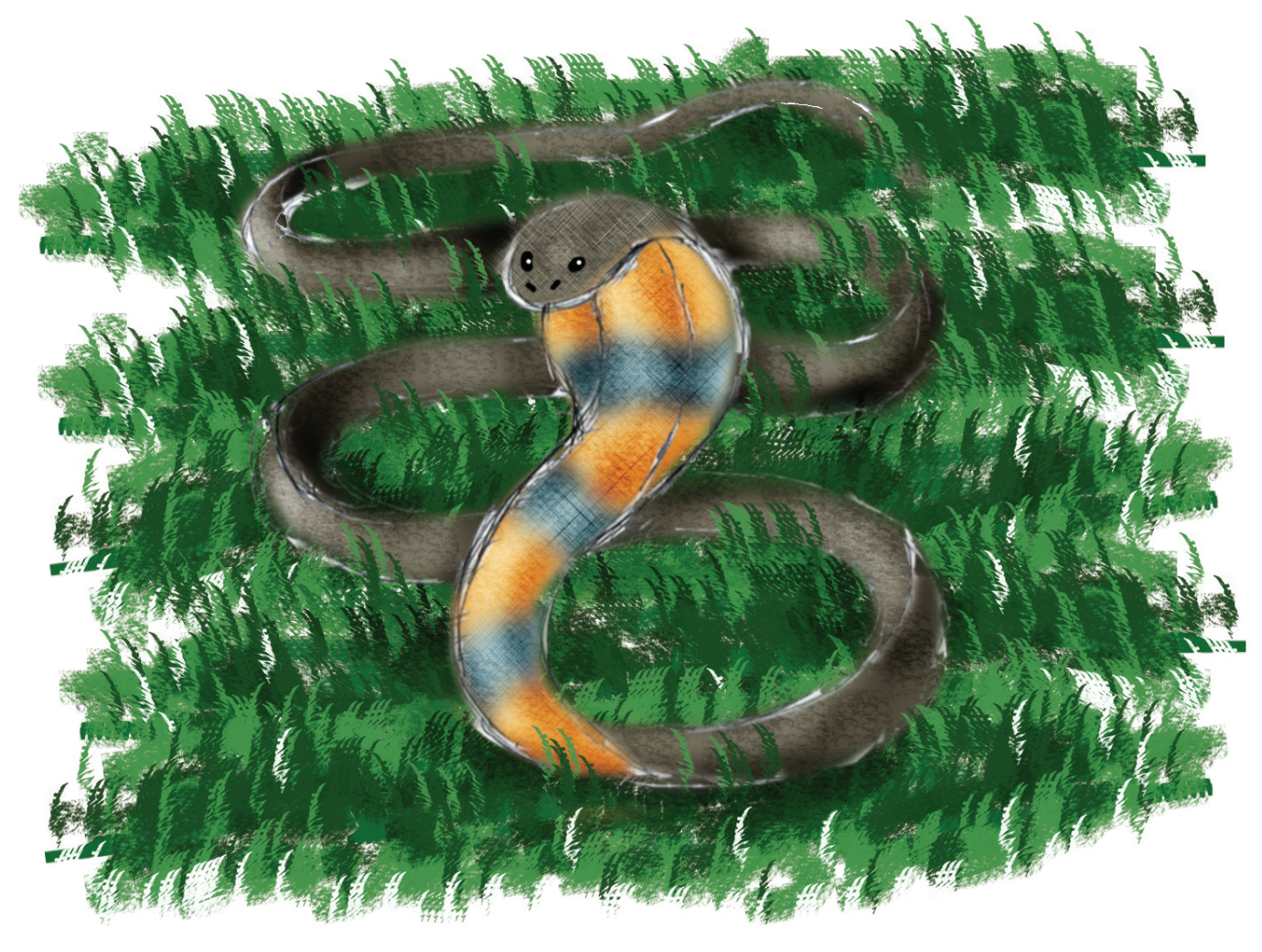

Figura 13.2: Uma cobra 


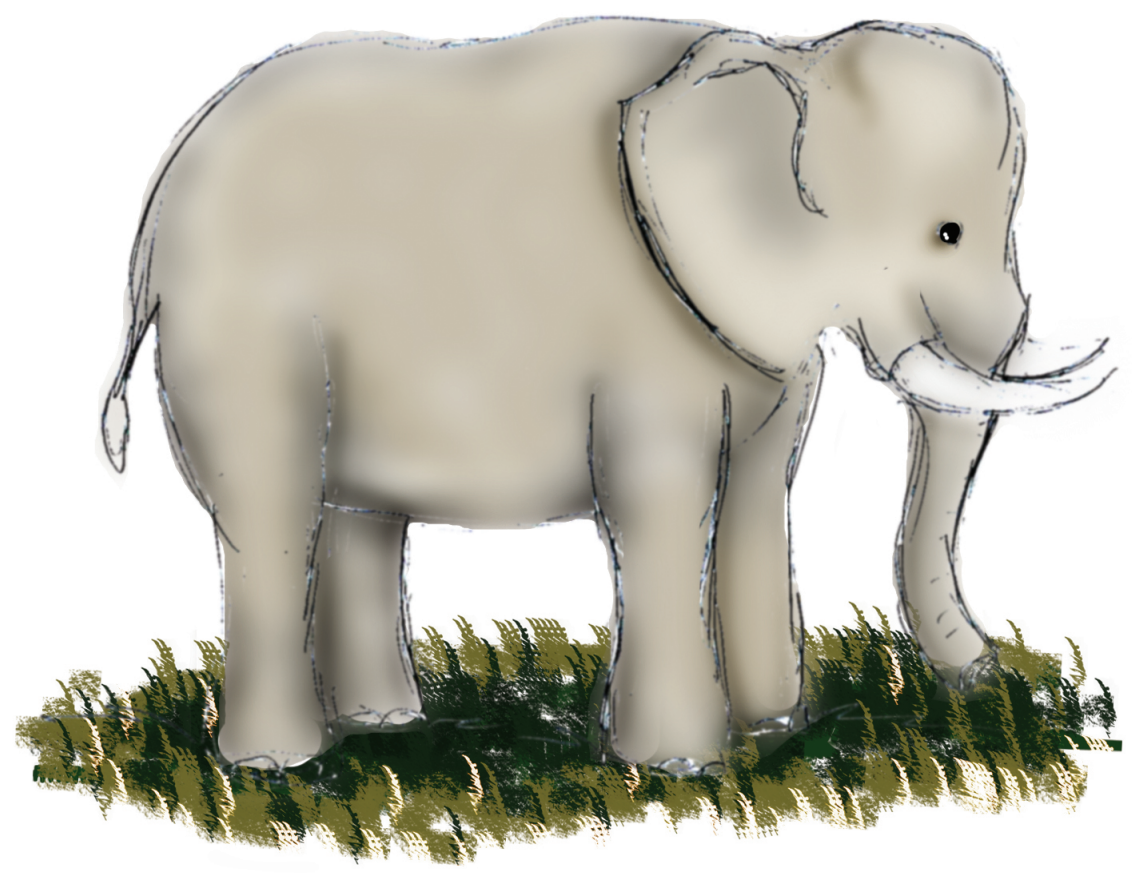

Figura 13.3: Um elefante 


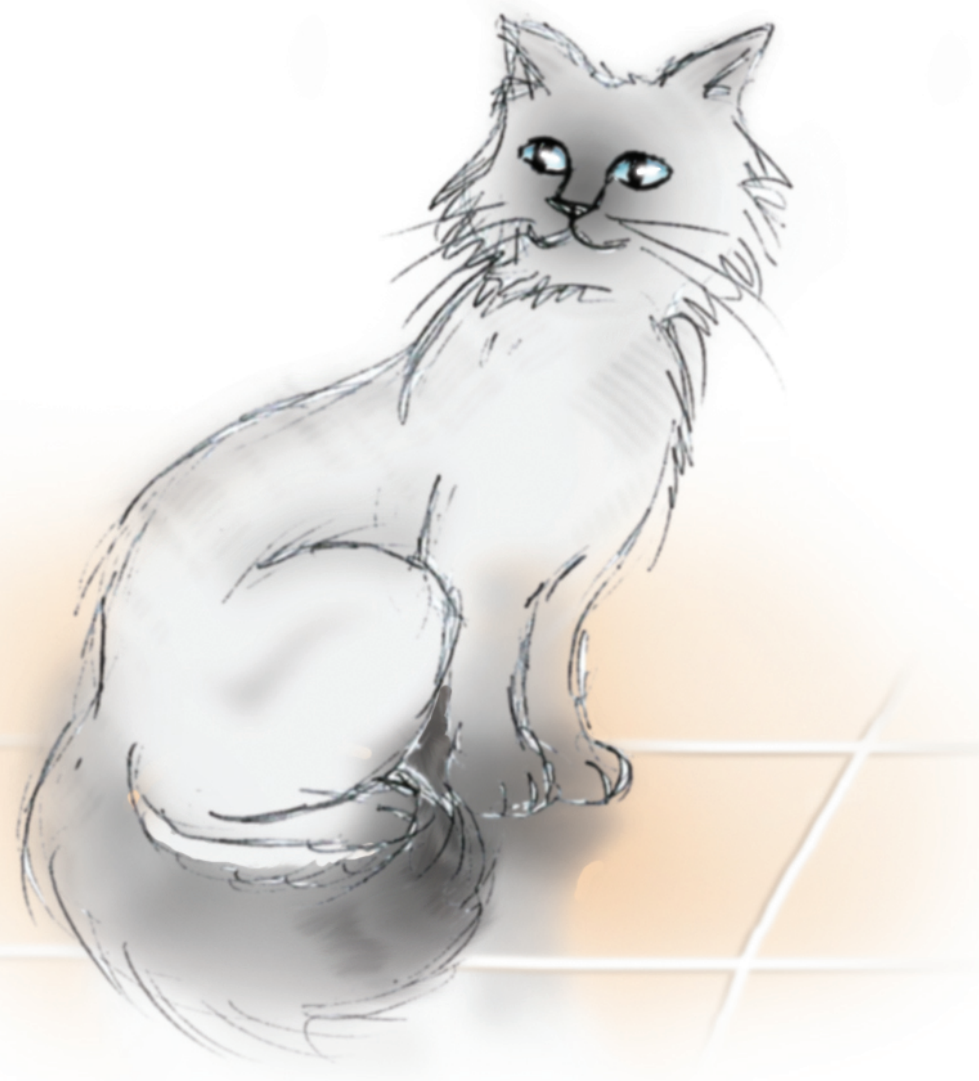

Figura 13.4: Um gato 


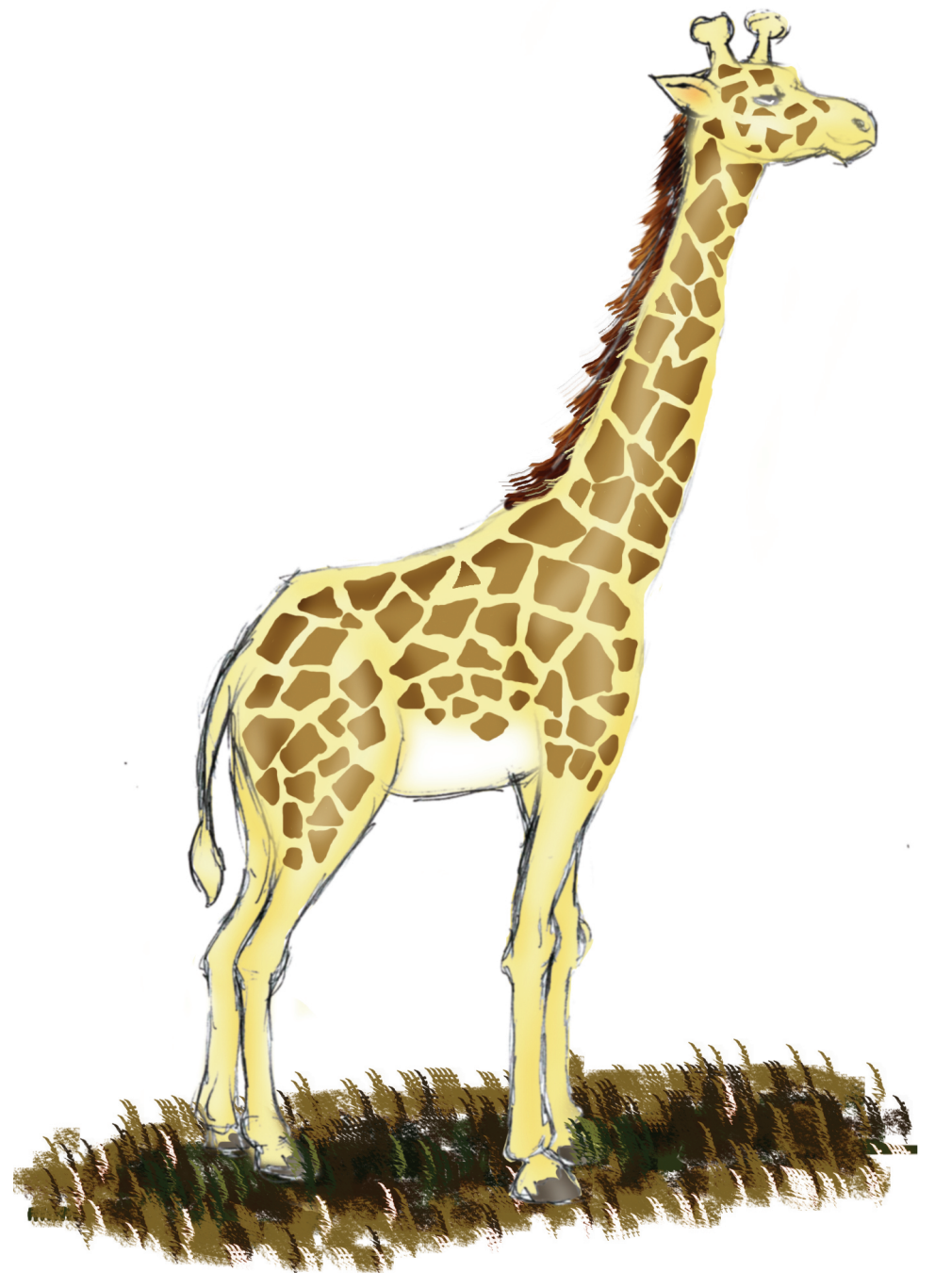

Figura 13.5: Uma girafa 


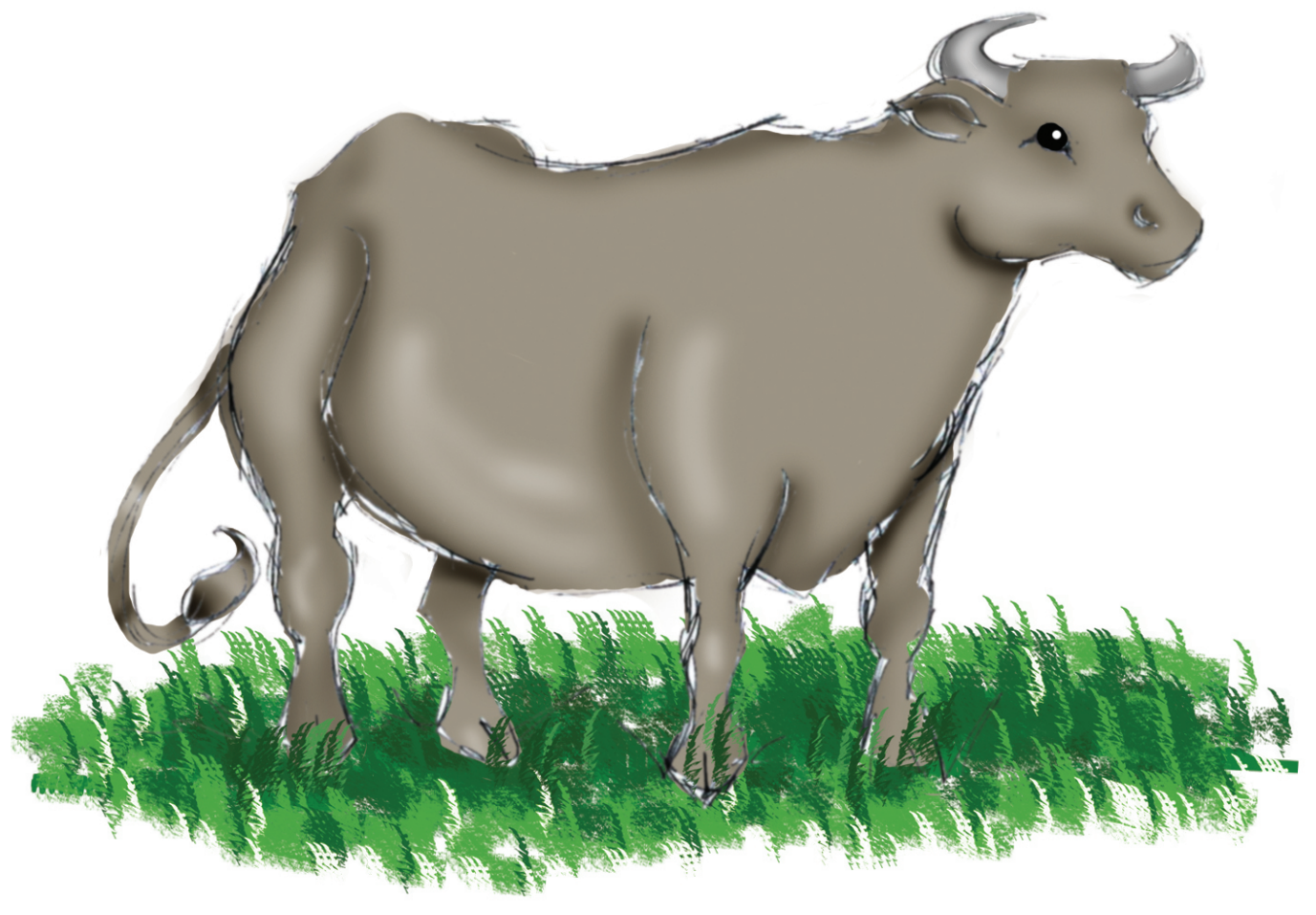

Figura 13.6: Um touro 


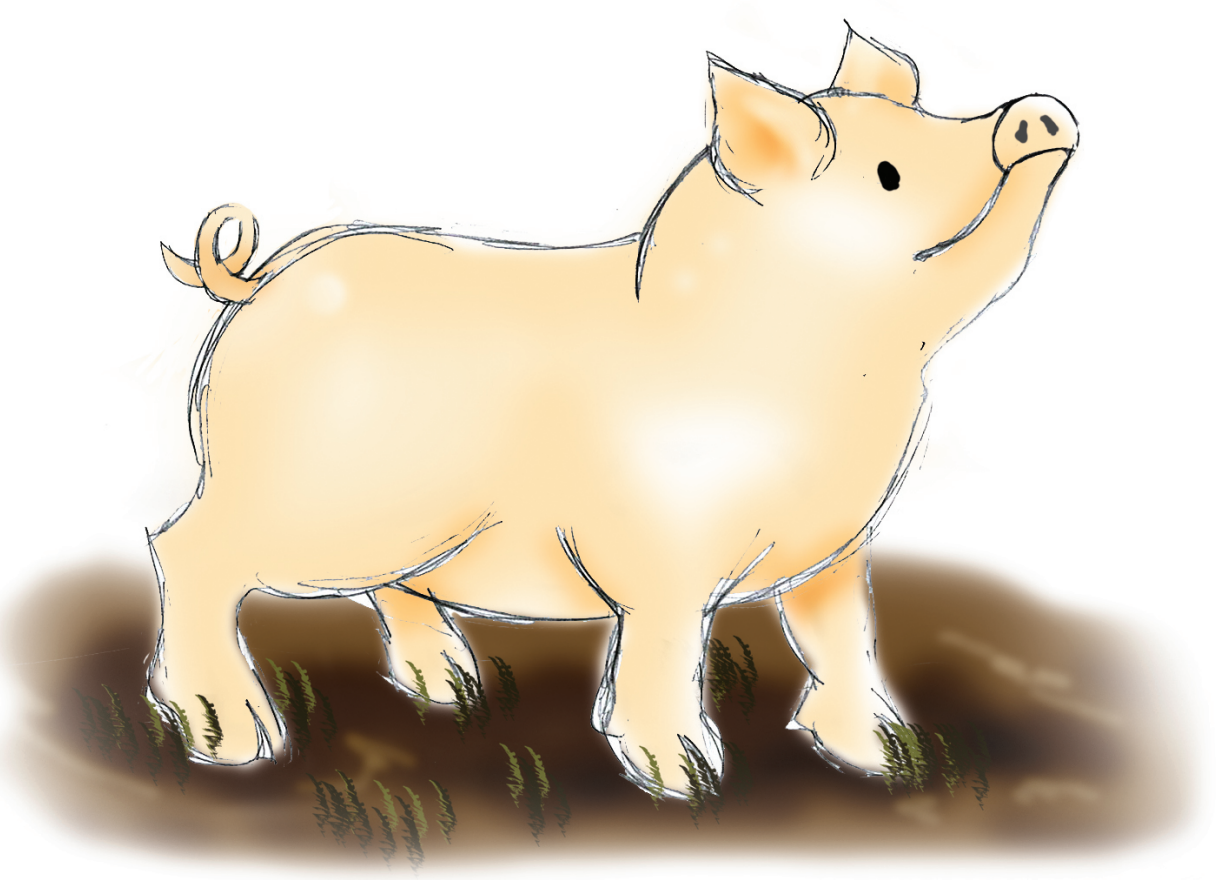

Figura 13.7: Um porco

$$
156
$$




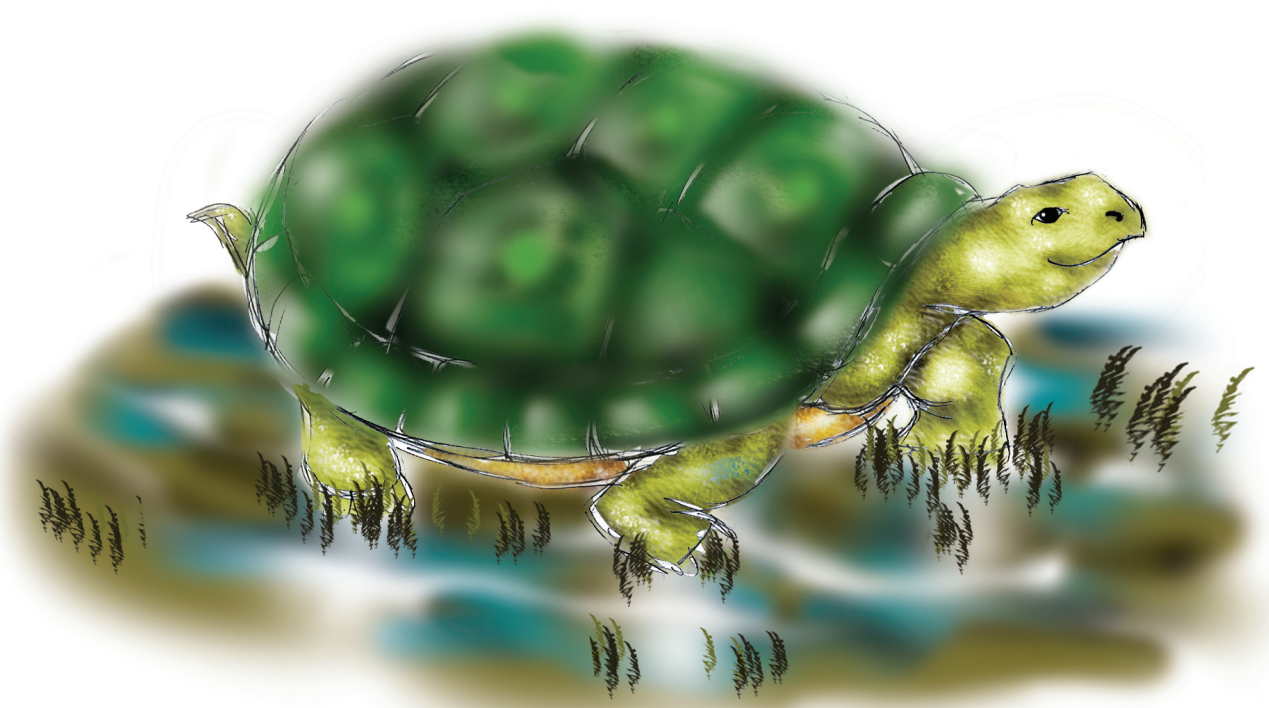

Figura 13.8: Uma tartaruga 
Figura 13.9: Uma baleia 


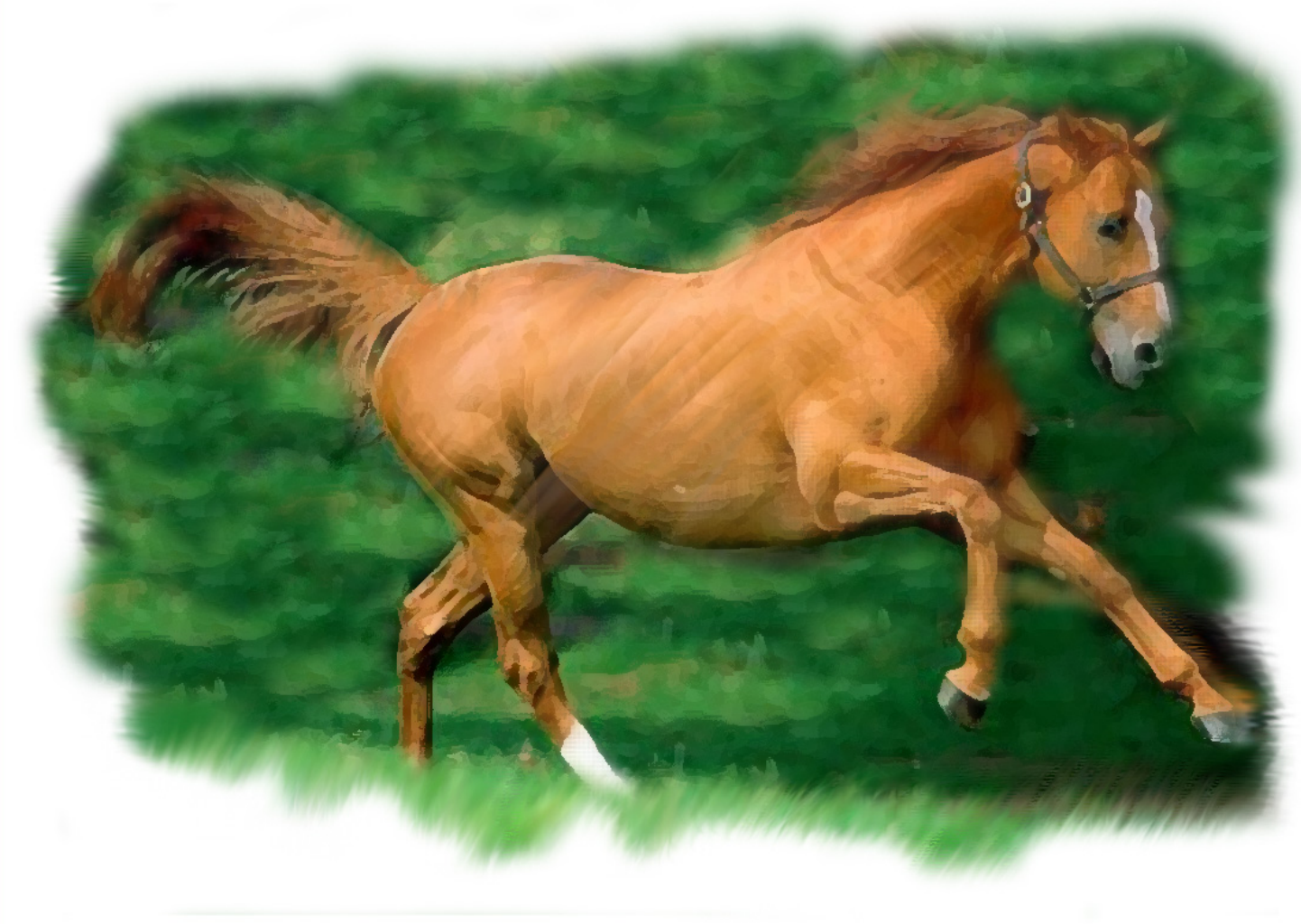

Figura 13.10: Um cavalo 


\section{Transcrição das entrevistas}

\subsection{Sujeito: AA}

Ent. AA, é o seguinte, eu to estudando como é que vocês conseguem lembrar os nomes dos animais. Então a gente vai ver se você consegue lembrar os nomes dos animais. Se você não conseguir lembrar, não tem problema, depois eu vou mostrar as fotos pra você, aí eu vou falar os nomes e você vai tentar apontar pra mim. Aí isso é mais fácil né? Então tá bom. Muito bem. AA, esse aqui é o primeiro animal.

AA (incompreensível) Gi a. Gia.

Ent. Muito bem, girafa, exatamente. Esse aqui? (mostra a figura de uma baleia)

AA Da ma. Do ma.

Ent. Do mar, isso. Tá certo. E esse aqui.(mostra a figura de um cavalo)

AA Cava. Cava.

Ent. Cavalo. Muito bem, esse daqui?(mostra a figura de um elefante)

AA $\ldots$

Ent. Não? Elefante, isso, tá certo. E esse daqui? (mostra a figura de um gato)

AA Gatin. Gatin.

Ent. Um gatinho, muito bem. E esse daqui? Não? Não? Tudo bem. E esse? (mostra a figura de uma cobra) 
AA Co - ba. Coba.

Ent. Cobra, ótimo. E esse? (mostra a figura de um touro)

AA Boi o.

Ent. Ótimo, muito bem. E essa?

AA ...

Ent. Não? Tudo bem, vou pular. E esse daqui? (mostra a figura de um burro)

AA É o bu- o. Bu.

Ent. Burro, ótimo. Muito bem, AA, agora olha só, eu vou te perguntar desses animais e aí ce só me diz assim, se você conseguir, eu quero que você me diga uma palavra sobre eles. Por exemplo, se eu falar pra você como que é uma girafa? Cê consegue pensar alguma coisa que ela é? Alguma qualidade dela, alguma característica?

AA (Sujeito faz que não)

Ent. Não? E se eu mostrar, ajuda?

AA Boni... boni.

Ent. É isso? E se eu perguntar pra você como é uma baleia, cê consegue me falar? Como que é uma baleia? Não? Se eu mostrar, ajuda?

AA É...ma...boni.

Ent. Tá. Se eu perguntar como é um cavalo?

AA (faz gestos como se montasse um cavalo)

Ent. Isso, dá pra montar nele? Isso. Lembra mais alguma coisa se eu mostrar a foto?

AA (incompreensível)

Ent. Que monta, né? Tá bom, se eu perguntar como é um elefante.

AA É muito pesa. 
Ent. Muito pesado. Isso, ótimo, muito bem. Se eu perguntar como que é um gato?

AA (faz gestos como se subisse uma parede)

Ent. Sobe as paredes? Isso, muito bem. Se eu perguntar como que é um touro?

AA $\ldots$

Ent. Não?

AA (faz gestos como se tivesse chifres)

Ent. Tem chifre, chifra as pessoas?

AA (incompreensível)

Ent. Ele tem chifre, corre atrás das pessoas, dá chifrada, né? Isso.

AA (incompreensível)

Ent. Isso, entendi, tá ótimo. Se eu perguntar pra você como que é uma cobra?

AA (faz gestos)

Ent. Comprida?

AA (incompreensível)

Ent. Ah, ela morde? Entendi, entendi, muito bem. Se eu perguntar pra você como que é um porco?

AA ...

Ent. Não. Se eu mostrar a foto?

AA É. (incompreensível) (faz gestos de garfo e faca)

Ent. Você come? Muito bem. Como é que é uma tartaruga? Não?

AA (faz gestos) 
Ent. Devagarinho? Ela é devagar, ela é lenta?

AA Deva-ga.

Ent. Devagar, muito bem. E último, como é que é um burro?

AA Bu-lo. Bu-lo.

Ent. Brilha?

AA (faz gestos de montar num burro)

Ent. Dá pra montar no burro também, é isso?

AA É. Pu-la. (faz gestos como se se prendesse alguma coisa no burro)

Ent. Ah, ele.. ele puxa o arado, trabalha? Ah, entendi, muito bem. Era só isso mesmo, AA, que eu queria saber, como que cê tava lembrando os nomes dos animais, cê tá muito bem. Brigada, tá?

\subsection{Sujeito: AC}

Ent. Acho que tá. Pronto. vou deixar mais pertinho do senhor tá? Então tá bom. Faz seis meses só?

AC Seis meses.

Ent. Ah mas então tá tudo bem! O senhor não tem nada não!

AC Graças a deus!

Ent. Amém. Então, tá bom, não tem nada não. Seu AC eu tô fazendo uma pesquisa que eu quero ver como as pessoas conseguem lembrar dos nomes e mais especificamente dos nomes dos animais.

AC Dos animais?

Ent. É.

AC Puxa vida hein, vai ser difícil hein.

Ent. O senhor acha? 
AC Hum.

Ent. Por quê?

AC Não sei nada de nada de animais.

Ent. Claro que sabe! O senhor não teve um bichinho de estimação?

AC Tenho. Tenho um cachorro.

Ent. Então...

AC Tenho.

Ent. Então. É coisa bem simples. O senhor só vai falar pra mim os nomes deles e depois eu vou fazer ums perguntas sobre eles, assim pro senhor me dizer como é que eles são, o que o senhor souber, não precisa ser assim uma explicação do tamanho do mundo. Ta.

AC Hã hã.

Ent. Vamos lá.

AC Vamos ver.

Ent. Como tá a sua lembrança de nome. (mostra a figura de uma girafa)

AC Chô ver se o, chô ver se eu lembro. Essa daí é a zebra né?

Ent. É a zebra? Hum hum.

AC Não não, zebra não. Não tô falando procê?

Ent. Curioso que o seu SR falou a mesma coisa quando ele veio aqui. Ele falou zebra também.

AC Tanta coisa eu num... num sou capa de falar!

Ent. Tenta um pouquinho, se o senhor não... não tem problema nenhum se o senhor não conseguir lembrar.

AC Ah meu deus do céu. Na.

Ent. Não? Não tem problema, fica tranquilo. Vamo lá. E esse daqui? 
AC Esse daí é aquele lá comé que chama, aquele coi que come a gente lá?

Ent. Que come a gente? (risos)

AC Hum, ai meu deus do céu. Tubarão.

Ent. Tubarão?

AC É. É ou não é?

Ent. Não é.

AC Não é.

Ent. Mas tem a ver. Esse aqui é mais bonzinho que o tubarão.

AC Não sei. Não sei.

Ent. Não? Tudo bem, depois a gente volta e eu vou lembrar o senhor então.

AC Aquele, é zebra aquele lá.

Ent. Zebra, esse daqui?

AC Não. Também não é.

Ent. Não é zebra. Então vamo lá, não tem problema. Agora a gente vai fazendo assim, eu quero ver o que que o senhor consegue lembrar sem ajuda nehhuma, tá? Depois quando a gente for fazer o... depois que eu souber o que o senhor sabe o que o senhor não sabe, a gente tenta de novo eu vou dar uma ajudinha aí tenho certeza que o senhor vai lembrar.

AC Mas eu eu sei, eu não...

Ent. Lembrar o nome, eu sei que o senhor sabe qual é...

AC É brincadeira né.

Ent. (Risos) Fica calmo seu AC. O senhor não fica nervoso não né?

AC Não não (risos). Vou ficar nervoso com o bichinho aí? 
Ent. Ah então tá bom. É, as vezes as pessoas ficam porque não consegue lembrar aí fica pensando, fica pensando aí fica... sabe...

AC Ah esse daí acho que...é um cavalo.

Ent. Ah muito bem, esse foi fácil né.

AC É.

Ent. E esse daqui?

AC Um elefante.

Ent. Ah agora sim, agora foi. E esse.

AC Um gato.

Ent. E esse?

AC Um boi.

Ent. E esse.

AC Uma serpente.

Ent. Uma serpente? É, tem o nome serpente e tem o outro nome.

AC É, tem. tem o...tem o... Deixa ver se tem o zigo no na, não tem o vizo não né? Cascavel não é?

Ent. Não...

AC Bom, é aquele que tem o negócio assim.

Ent. Tá. Tá ótimo.

AC Eu não gosto de cobra, eu tô longe disso.

Ent. Cobra. Era esse o nome que eu tava pensando.

AC Hum.

Ent. Esse aqui?

AC Uma... um... o coiso. O porco. 
Ent. Porco, muito bem. E esse aqui?

AC Bom, parece jacaré. Jacaré não. Cágado.

Ent. Cágado? O senhor lembra das palavras mais difíceis, não lembra das mais fáceis! Serpente...

AC Não, isso aí pra mim é cágado, não tem outra coisa, pra mim é.

Ent. Se ele fosse, se ele vivesse na água...

AC Não t...também.

Ent. Cágado?

AC Cágado.

Ent. Certo. Pode ser também, é que eu tava pensando num outro, num mais fácil ainda, de lembrar. E esse aqui.

AC Um burico.

Ent. (Risos)Um burro. Muito bem seu AC, o senhor tá lembrando tudo. Agora vamo vê.

AC Como é o nome daquele?

Ent. Ah vamo olhá!

AC É zebra esse aí?

Ent. Não, não é a zebra. É a gi...

AC Hum?

Ent. É a gi...?

AC (Suspiro) Meu deus. Cê sabe que... cê sabe que tá sempre na TV.

Ent. Na TV né?

AC Pois é.

Ent. No zoológico. Girafa. 
AC Girafa! Ah minha, meu santo deus. Esse eu também não sei.

Ent. Esse daqui.

AC Não sei. Não sei.

Ent. Que vive na água? Não? Baleia.

AC Baleia.

Ent. Baleia.

AC Baleia.

Ent. Agora lembrou? Fez mais sentido? Vamo ver seu AC então, agora sem olhar...

AC Olha, já esqueci o nome desse daí.

Ent. Desse daqui?

AC É, esqueci dele.

Ent. Girafa.

AC Girafa.

Ent. Vem e vai né? Mas o senhor tá lembrando de todos os outros. Tá super bem. Tá super bem.

AC Hum.

Ent. Vamo lá. Agora sem olhar as figuras, eu vou perguntar pro senhor e o senhor me diz. É... se eu perguntasse pra você: como é que é uma girafa? Como que o senhor descreveria ela pra mim?

AC Bom, que come capim.

Ent. Come capim...

AC Come capim, outro... outro coiso lá pa pa sobreviver. Certo?

Ent. Tá... Se fosse pra descrever ela fisicamente. Faz de conta que eu nunca vi uma girafa, eu não sei como ela é... 
AC Eu também... (risos) mais ou menos...

Ent. (Risos) Não é muito fácil... de explicar...

AC Não...eu não tenho a menor ideia de como é que ela vive.

Ent. Ahãm.

AC Não tenho como...

Ent. Mas o senhor sabe como é que ela se parece?

AC Ah ela se parece com... eu sei que ela é...grandona, tem o pescoço grande também...

Ent. Isso. Isso, isso... é só isso que eu quero, fala assim por cima, não precisa explicar muito não. É isso que o senhor diria então, que ela é alta. E o que que o senhor diria pra mim de uma baleia?

AC Hum.

Ent. Como é que é uma baleia?

AC Eu... num... isso aí eu num sei, num sei qual é a vivência dela. Não sei nada.

Ent. Hum, mas o senhor já viu tipo assim... na TV, em desenho?

AC Já vi. Já.

Ent. Então fala pra mim.

AC Num sei o que que ela come, num sei o que que ela faz.

Ent. Ahãm, mas como é que ela se parece, qual é a aparência dela.

AC Parece com...com ....com...

Ent. Só fala assim, se ela é grande, se ela é pequena, onde que ela mora...

AC Ela mora debaixo d'água.

Ent. Ok, já é um começo, e que mais, ela é pequena ou é grande. 
AC Ah é grande...

Ent. Grande, bem grande? Hum hum.

AC É bastante grande.

Ent. Hum hum. Tá, vamo pulá. E como é que é um cavalo?

AC Cavalo come capim...

Ent. Ahãm.

AC Entendeu?

Ent. Sim.

AC É...carrega gente em cima dele. Tá escutando?

Ent. Sim.

AC Põe a...o...o...como é, bota o negócio em cima dele, a... o areio. Entendeu?

Ent. Ahãm.

AC Come... milho. Come tantas coisas lá. Eu tenho muito (incompreensível)

Ent. Sei. O senhor cresceu em fazenda támbém? O senhor creseceu em fazenda?

AC Não teve fazenda. Não teve por causa do meu pai, senão tendia sido fazendeiro também.

Ent. Ahãm, por quê?

AC Ele tendia o vinhedo... as coisas...

Ent. Ahãm, entendi, mas o senhor cresceu assim, cuidando de cavalo...

AC Muito, muito.

Ent. De boi... 
AC Muito, muito, muito. Cavalo, vaca, tirei muito leite de vaca.

Ent. Entendi, então o senhor vai saber todos os nomes aqui. E seu AC, fala pra mim como que é um elefante.

AC (Suspiro) Ele come capim. Toneladas de... coiso. E depois num num não sei mais nada dele. Eu diria que tem bastante... oreion. Aquilo deve ser oreia pa caramba.

Ent. (Risos) Tem aquele orelhão, tá certo, que mais?

AC Tem o...elefante com o dente grande.

Ent. Ahãm.

AC Entendeu?

Ent. Tá. Mais alguma coisa?

AC Não pode deixar ele nervoso que ele corre atrás da gente.

Ent. Ouvi dizer também.

AC É isso aí.

Ent. Que mais, diz pra mim como é que é um gato.

AC Um gato?

Ent. É.

AC (Suspiro) Gato. Tive muito gato também.

Ent. É, e como é que eles são?

AC Gato. Não pode deixar nada de de de de... de peixe pra ele.

Ent. Por quê? Ele come?

AC Urr...e como, e como come. É isso, é isso aí só.

Ent. Que mais, ele é pequeno, ele é grande?

AC Pequeno, grande 
Ent. Desse tamaínho?

AC Perto da minha casa...

Ent. Esse aí é grande até hein? (Risos)

AC É verdade, é grande, eu peguei. Cada bichão desse tamanho assim.

Ent. Nossa, tão alimentando esses gatos com quê? Tão dando leite direto da vaca pra esses gatos.

AC (Risos) Nossa senhora.

Ent. Tá bom.

AC Tem uma vizinha lá que o gato dele sempre escapa. Não é que ele vai buscar na minha casa judas... ajuda pra buscar o gato dela.

Ent. Ixi que trabalho hein. Correr atrás de gato em lugar aberto assim que nem aqui, em sítio. Muito bem. E seu AC como é que é um boi?

AC O boi... o boi gosta de mamar, pra passar, fazer é... churrasco.

Ent. (risos)

AC Ou você não gosta de churrasco?

Ent. Gosto. Mas eu não gosto muito de pensar que era um boi antes sabe... não gosto de ficar pensando "ah isso é um boi”. O seu SR tava me contando que ele matava boi na fazenda. O senhor já fez alguma coisa assim?

AC Não não não, eu gosto de ficar... eu gosto é de ficar lá no mato, só. Entendeu?

Ent. Ahãm, quietinho.

AC Eu, lá...é...eu, como que, eu tenho, eu nunca vi matar boi.

Ent. Ah que bom, deve ser difícil, eu não ia gostar de ver não.

AC A hora que eu... a hora que eu vejo matando, eu viro. Não vejo matar não. 
Ent. Eu também acho, eu também... acho que eu não ia gostar de ver não. Muito menos de fazer. Tudo bem, mas como é que ele é, como é a aparência dele assim, dá pra fazer churrasco, tá, mas que mais?

AC Ah ele é tamanho assim, né?

Ent. Hum hum, grande...

AC Come bastante capim. Entendeu?

Ent. Entendi.

AC E quando dá ração pra ele, ele vai bem também né.

Ent. Hum hum, ele come tanto capim quanto ração. Tá, como é que é uma cobra?

AC Não, não não. A cobra pra mim, fica longe de mim.

Ent. Mas o senhor já viu? Sabe como é?

AC Já vi, matei... entendeu.

Ent. O senhor não gosta?

AC Não, não. Eu não. Esse aí... não não, eu quero ficar bem longe. Matei muito dessa cobra quando morava na fazenda.

Ent. Sei.

AC Matei muito disso aí.

Ent. E como que eram essas cobras que o senhor matou.

AC Hã?

Ent. Como é que elas eram?

AC Ah tinha cobra de mais de dois... mais de três metros de altura. De altura não, de comprimento né? Eu matei uma jara... cascavel que tinha... doze ano ela tinha. Conhece cascavel?

Ent. Conheço. Nunca vi, graças a deus, mas... 
AC Você tem... cada, cada ano que ela tem ela, que ela... cada ano que ela fazia aumentava um gominho de coisa no rabo dela.

Ent. Ah do chocalho.

AC É, do chacalho.

Ent. Ah entendi. E aí o senhor contou e tinha doze?

AC É.

Ent. Nossa devia ser...

AC Doze. Tinha... devia ser mais ou menos desse tamanho assim, que ele tinha.

Ent. Ai. Que medo. Devia fazer um barulhão né?

AC Ah! Pelo amor de deus viu!

Ent. Que medo. Eu teria medo. Que mais, seu AC como é que é um porco?

AC Um porco. O meu pai matava muito porco, e eu ia pegar o sangue do porco, pra fazer choriço.

Ent. Fazer... faz choriço com o sangue dele?

AC É. Fazia choriço, cuzidin, issas coisa aí tudo com o sangue dele. Minha mãe fazia isso aí.

Ent. E como é que era o porco antes de... antes de virar choriço? (Risos)

AC (Risos) O porco ele tem... tinha de ficar... ficar mais ou menos grande, põe ele num chiqueiro lá, ele fica sozinho lá dentro.

Ent. Hum hum.

(Interrupção)

Ent. Continuando, pera aí. O senhor tava falando do porco né?

AC Do porco.

Ent. E aí? 
AC Então, ele vai na cela, lá ele fica sozinho, comendo do bom e do melhor...

Ent. Ah é, não sabia disso não.

AC Ah, pra ele ficar troncudo...

Ent. Gordinho.

AC Aí a turma enfia a faca nele.

Ent. Aí a gente come do bom e do melhor. (risos)

AC É. (risos)

Ent. Muito bem, tamo acabando seu AC. Como é que é uma tartaruga?

AC Uma tartaruga. Bom, a tartaruga tem... um bicho que é... ela enfia a cabeça e fica tudo embaixo lá... do coiso lá. Entendeu? Ela vive na água, entendeu?

Ent. Tá.

AC Não... não sei o que eu ela come...

Ent. Tudo bem.

AC Dessas coisa, não sei mais nada.

Ent. O senhor sabe que ela vive na água...e...como é que ela nada, ela nada rápido, ela nada devagar...?

AC Num, num, num trabalha rápido não, porque ela é muito molenga também.

Ent. Muito molenga né, muito lenta.

AC Ahã.

Ent. Tá certo, e o último, diz pra mim como é que é um burro.

AC Bom, o burro, é mais burro do que o burro. (risos) Entendeu?

Ent. (Risos) Por quê? 
AC Porque o coiso chega... orra você é burro pa caramba né? (risos)

Ent. É.

AC Não é verdade? Então, é o verdadeiro burro aí.

Ent. Porque o bicho é burro mesmo?

AC É burro pa caramba. É um burro.

Ent. O senhor já trabalhou com burro na fazenda?

AC Não.

Ent. Não?

AC Trabalhei com cavalo.

Ent. Ah com cavalo, tá.

AC Porque o burro com o cavalo é completamente diferente. Entendeu?

Ent. Ahã, sei. E por que que o burro é burro?

AC (risos)

Ent. Ele é teimoso?

AC Não é, é que é burro mesmo, entendeu.

Ent. O cavalo já é inteligente?

AC O cavalo já é mais inteligente. Tantas coisas quando cê vê...é...cê pode ver... burro só tem lá no... no... não vou dizer que os cara lá é burro também né?

Ent. Claro.

AC No nordeste lá, só trabalha com burro só.

Ent. É.

AC O burro (incompreensível) não vou dizer que o coitado é burro também né? 
Ent. Claro. Mas lá tem mais burro mesmo.

AC Exatamente.

Ent. Porque eles são mais... resistentes, talvez, que o cavalo. Cavalo precisa de mais cuidado assim?

AC Porque o coitado põe todo o que, tudo o que põe em cima dele, ele leva.

Ent. Ahã.

AC Entendeu?

Ent. É. Burro de carga né?

AC É, burro de carga. Ele então, então é isso aí.

Ent. É por isso que ele é burro? (risos)

AC (risos) Pelo amor de deus, não vá, não vá...

Ent. Claro que não!

AC Que os cara é burro! Os cara lá que trabalha só com burro porque é...trabalha... como é que eu posso falar? Tem coisa que não sai a...a...

Ent. A palavra.

AC A palavra. Enfim.

Ent. Tá bom, muito obrigada seu AC, eu tava querendo ver mesmo como é que você...

\section{$13 \cdot 3$ Sujeito: $\mathrm{CP}$}

CP Não lembro... mas eu num...

Ent. Não lembra?

CP É. Porque tem a... a... lembro, mas não... 
Ent. Não consegue falar? Hum hum, entendi. Tudo bem. A senhora... faz tempo que a senhora tá assim? Isso a senhora...

CP Hum...um pouquinho...é mais hã...é mais hã...(risos)

Ent. (risos) Fica tranquila.

CP Três... não, dois anos, mas um pouquinho...

Ent. Mais?

CP Não.

Ent. Um pouquinho menos?

CP É. Um pouquinho menos.

Ent. E a senhora tá se virando bem, tá melhorando?

CP Não... mais ou men...

Ent. Devagarinho né? Tem que vir fazer as terapias...

CP Ai...vixi...vai vai vai! (risos)

Ent. Mas vai né? (risos) Tem que ter perseverança! Dona CP é assim mesmo. Muito bem, dona CP meu nome é Bruna, eu sou da USP, e eu to fazendo uma pesquisa no meu mestrado que tem a ver com como que as pessoas conseguem lembrar dos nomes dos animais. A senhora tem dificuldade pra lembrar os nomes das coisas ou pra falar os nomes das coisas?

CP Chô vê.

Ent. Eu vou mostrando um por um pra senhora...

CP Eu lembro aqui, mas é...gi-rafa.

Ent. Girafa, muito bem, eu vou mostrando um por um pra senhora a senhora diz o que a senhora conseguir lembrar, tá? E esse aqui?

CP Golfinho.

Ent. Golfinho. 
CP Ai...humm.., pronto ó. Essa demora que... corcel, mas não é bem o...

Ent. Mas tem a ver.

CP Mas não...

Ent. Cavalo.

CP É (risos).

Ent. Isso. Ótimo.

CP Girafa. Ah... pronto não sei, porque essa aqui... ah não...

Ent. Esse aqui não?

CP Mas elefante não é, aqui é uma...

Ent. A senhora acabou de falar!

CP Hã?

Ent. A senhora falou sem querer, o nome dele.

CP Girafa não. Não sei onde. Ah não sei não.

Ent. Mas a senhora falou sem querer, a senhora fala "esse aqui, mas não", mas era ele mesmo.

CP Girafa não. Não sei.

Ent. Elefante. Elefante.

CP Não sei.

Ent. Não? Olha aqui pra mim. Elefante.

CP Mas ela conseguiu, ela só que ela fica dentro, e a gente não... não sabe.

Ent. Elefante.

CP É. Se...um elefante.

Ent. Isso, muito bem. E esse aqui? 


\section{CP Gato.}

Ent. Muito bem. Esse daqui?

CP ....Ah...o...o... não sei. Ai eu... tá assim...

Ent. Tá na ponta da língua mas não sai né?

CP É... Touro.

Ent. Touro, muito bem. E essa daqui?

CP O que que é isso? Não sei... ah! É a... nara... lara... não. Ah eu não sei.

Ent. Cobra.

CP Ah nossa, tudo assim.

Ent. É que a senhora devia tá tentando falar...

CP Não não...

Ent. Era outra coisa?

CP É.

Ent. Se a senhora conseguir, então a senhora me fala que eu fiquei curiosa agora. E esse daqui?

CP Porquinho.

Ent. Muito bem. E esse daqui?

CP ... ai não sei... se vai... ai não sei, aqui ó, muito parecido... ai eu não sei não.

Ent. Não tem problema. Vamo pulá. E esse aqui?

CP ... ai num sei não. Falá. Hum...é...

Ent. Não?

CP Eu não sei porque ali ó, não sai.

Ent. Não. 
CP Mas eu... Tá ali.

Ent. Tá ali na ponta mas não consegue sair? Num tem problema. Ó, essa foi a primeira parte, agora eu vou fazer uma segunda parte, pra senhora me responder, tá? A senhora assim, se a senhora conseguir me dizer uma palavra sobre esses animais tá ótimo, tá? Não precisa falar muito não, não tem problema. Se eu perguntar pra senhora, dona $\mathrm{CP}$, como é uma girafa?

CP Girafa? Hum....ah não sei viu...

Ent. Não? Se a senhora me falar assim, faz de conta que eu nunca vi uma girafa, aí eu chego "não, dona CP, como que é uma girafa?" uma palavra que a senhora lembrar...

CP Girafa...

Ent. A senhora lembra qual bicho é a girafa?

CP Ele sabe...(risos)

Ent. Lembra?

CP É!

Ent. Às vezes esquece...

CP Não...

Ent. Não? Se eu mostrar a figura pra senhora, ajuda?

CP Girafa...Humm...não...

Ent. Não? Muito difícil? Não tem problema. Se eu perguntar pra senhora como é uma baleia?

CP Hum, mas o que que é... eu não sei...

Ent. O que... o que responder? Por exemplo, uma das coisas que a senhora podia me dizer da girafa, por exemplo, é que ela é alta.

CP Ah sim sim! 
Ent. É!

CP Ah então b... alta.

Ent. Então, a girafa é alta, como é que é a baleia?

CP Ah... mais eu num...

Ent. Não, difícil lembrar? Se eu mostrar a figura ajuda? A senhora pode dizer assim se ela é grande, se ela é pequena, onde ela mora...

CP Ah...não...

Ent. Não? Não tem problema. Dona $C P$, como é um cavalo?

CP Ca-va-lo. Alto.

Ent. É alto? Muito bem. Como é um elefante?

CP Ah... Mas como é que é hein...

Ent. Vou mostrar a foto.

CP Bravo.

Ent. Bravo, muito bem. Como é um gato?

CP Teimoso.

Ent. Teimoso? Eu acho também. Como é, dona $\mathrm{CP}$, um touro?

CP Ah eu num sei. Tá...

Ent. O barulho de fora tá atrapalhando a senhora?

CP É. Eu fala, os outro fala. Não sei. Não.

Ent. Atrapalha? Não tem problema, vamo pulá então. Lembrou alguma coisa?

CP Ba...bravo.

Ent. Bravo, muito bem. Como é uma cobra?

CP Ninja. 
Ent. Ninja, muito bem. Como é um porco.?

CP Mas não pára...

Ent. É uma pena que não dá pra fazer uma sala isolada né, mas tenta se concentrar presta atenção em mim.

CP O porco... o cara não é... humm... porco...

Ent. Não? Não tem problema, tá difícil de se concentrar. Eu queria muito fazer parar né, mas... Como é uma tartaruga?

CP Tartaruga... fininha. Fininha...(risos)

Ent. Fininha? Muito bem, como é um burro?

CP Um burro? Ah... humpf... não, não sei, na na nana.

Ent. Atrapalha né dona $\mathrm{CP}$, tá bom, não tem problema. Muito obrigada, pela sua ajuda, desculpa tirar a senhora da terapia.

\subsection{Sujeito: DP}

Ent. Aqui. Pronto, acho que começou. Vou deixar aqui mais pertinho da senhora pra pegar sua voz tá?

DP Tá.

Ent. Dona DP, o que que a senhora teve?

DP Eu tive um derrame isquêmico. Já faz bastante tempo, foi em 2000.

Ent. Sei.

DP Aí eu fiquei, eu eu tive o derrame e eu não fiquei sabendo. Eu tive uns sintomas assim... diferente, eu comecei a sentir... a memória começou a falhar. Comecei a... a fala ficou um pouco com dificuldade mas... e umas, eu comecei com umas agulhadas na cabeça.

Ent. Sei. 
DP E eu fiquei muito preocupada porque o meu irmão tinha falecido... meio recente da época... com câncer no cérebro.

Ent. Sei...

DP E eu fui ao médico mais preocupada com isso, não preocupada que eu pudesse ter derrame, eu nunca pensei...

Ent. É que a gente sempre ouve umas histórias super pesadas né...

DP É, e eu sempre tive medo do derrame, mas eu não sabia que o problema para o derrame era a pressão alta. E eu, até então, nunca tinha medido pressão, nem fiquei sabendo que eu tinha pressão alta, entendeu?

Ent. Entendi.

DP Aí eu fui, quando eu comecei a sentir essas agulhadas na cabeça, eu fui num neurologista, aí ele mandou, primeiro mandou fazer um eletro, depois mandou fazer uma tomografia. Quando eu peguei o resultado da tomografia, ele estava de férias, o médico. Aí, eu li assim o resultado, mas não entendi, tinha umas palavras diferentes. Aí eu tenho uma sobrinha que mora em São Paulo, e ela tem uma amiga que o marido é neurologista. Aí eu liguei pra ela e falei "olha eu vou passar o resultado, pergunta pro médico que o meu tá de férias, e eu to preocupada, essas palavras eu não entendo... o que quer dizer".

Ent. Hum hum.

DP Na época eu nem me preocupei em ver pela internet, poderia ter visto, né? Aí ela... passou uns dias, ela ligou pra mim e falou assim "ah não é nada, você não precisa se preocupar, deixa quando o seu médico voltar que ele explica direitinho" e não quis falar pra mim o que era.

Ent. Hum...

DP Aí quando o meu médico voltou que eulevei o resultado ele olhou e falou "ah, não é nada"...

Ent. Não acredito! 
DP Ele falou pra mim "não é nada, não precisa se preocupar" nem falou em pressão, não falou nada. Aí, eu achei que não era nada, continuei a minha vidinha, né? Nem me preocupei com pressão, não preocupei...e aí, eu pensava, como eu tinha feito um implante, uns anos antes, eu tinha, eles pegaram um nervo aqui, na boca, e... ele falou "vai voltar, mas demora um pouco". Eu achei que essa dificuldade era porque o nervo tava voltando, quando não era verdade, era do problema que eu tive. Aí foi, quando acho que passou uns dois anos, eu vim num cardiologista, nós morávamos numa chácara aqui perto, que nós...o meu marido aposentou, nós morávamos em São Paulo, e eu pedi transferência pra cá porque eu ainda estava trabalhando, e a gente foi morar nessa chácara. Então, eu vinha trabalhar aqui em Campinas, eu viajava. Depois, eu me aposentei. E nesse período, que aconteceu isso, eu fui contratada. Eles tavam precisando de uma pessoa que entendesse do serviço e me contrataram na prefeitura...

Ent. O que que a senhora faz?

DP Eu trabalhava no INSS. E então eles, eles iam abrir uma agência lá, e eles precisavam de uma pessoa. Aí a minha ex chefe sabia que eu tinha aposentado e me chamou. Como eu tava sem fazer nada mesmo, só aposentada, eu falei "eu vou". E foi nesse período que eu tive. Aí foi, passou um tempo, eu vim nesse cardiologista aqui em Campinas e ele foi e fez eletro, mediu pressão, disse que tava tudo normal, mas que na nossa idade, minha e do meu marido, a gente precisava ir fazer... ir num neurologista, por causa da nossa idade. E o meu marido precisava fazer uns exames de sangue e tal. Então nesse período que nós fomos no neurologista e eu levei tudo que eu tinha. Nesse neurologista ele falou pra mim, ele falou "mas como que o médico viu esse resultado e não falou nada pra você? Você teve um derrame.".

Ent. Nossa.

DP Mas pra via das dúvidas, vamos fazer um agora, atual, uma tomografia. Fez a tomografia, na tomografia falou que aconselhava eu fazer uma... ressonância. Aí fui fazer a ressonância. Aí falou que eu tive um derrame isquêmico, no lado que já tava morto, aí deu um monte de coisa, mas nessa altura eu me liguei e fui na internet olhar. Aí 
fiquei muito preocupada né? Mas esse médico que me atendeu, esse neurologista, ele fez a mesma coisa que o outro. Ele criticou tanto o outro, e ele fez a mesma coisa, quando eu vim com o resultado ele falou "ah, não é nada, eu vou receitar um calmante, a senhora toma..." e nem falou de pressão, nem nada.

Ent. Ahãm.

DP E eu saí revoltada de lá. Mas como, eu cheguei aqui, ele acabou com o outro médico né? E ele fez a mesma coisa. Eu não tive coragem e falar pra ele isso, mas eu saí com aquilo aqui. Aí o que que eu fiz, o meu sobrinho tava tratando com um neurologista, e ele é professor aqui da Unicamp. Aí eu falei "ah, vou marcar uma consulta com ele" aí fui lá, é o doutor Yves Fernandes, não sei se você já ouviu falar...

Ent. Não...

DP Ele é professor. Aí eu fui lá, ele me explicou tudo, ele pôs lá... a ressonância, mostrou pra mim a parte do cérebro, falou "essa parte tá morta, não vai voltar mais, aí você vai ter que trabalhar com o resto que ficou, e daqui pra frente você tem que medir a pressão todo santo dia, tomar remédio, sempre controlando a sua pressão".

Ent. Olha só...

DP Aí, aí que ele me falou que eu tinha risco, o que que podia acontecer no futuro né? Ele falou "ah não se preocupe, isso aí é mais pra frente, a senhora pode ficar sossegada, falou pra mim, daqui há uns dez anos aí que a senhora começa a se preocupar", só que agora tá fazendo dez anos! (risos)

Ent. (risos) Aí agora a senhora tá pensando né?

DP Aí agora to com medo até de... de fazer outra ressonância, porque...

Ent. Ah mas tem que fazer! Pra saber né!

DP É, mas eu não sei o que é melhor, se é melhor eu esquecer ou melhor saber!

Ent. Não, melhor saber! Já pensou? Pega a senhora desprevenida? 
DP Aí que eu percebi... que, quando eu conversava, meu marido principalmente, em casa, falava "você tá falando enrolado" e era esse lado aqui, que eu achava que era do implante, não era! Era daquilo. E até a memória minha, eu tinha uma memória fabulosa. Lembrava de tudo, lá no serviço, nossa, todo mundo vinha perguntar pra mim porque era muita legislação lá, né?

Ent. Sim.

DP Então começou a falhar, né, e começou a falhar também essa dificuldade de falar, quando eu queria falar uma palavra e não vinha!

Ent. Hum hum... mais do que antes?

DP Mais do que antes.

Ent. Porque às vezes, a gente... acontece isso né?

DP Não, é, direto. Aí comecei a ficar retraída, porque eu não podia falar em público, não podia falar assim, porque eu queria falar...

Ent. Mas a senhora tá tão bem agora!

DP Agora, mas quanto tempo já. Mas é do tratamento, porque aí ele falou pra mim, esse médico falou " a senhora não pode parar, se a senhora parar o negócio engrossa! Daqui pra frente a senhora procura um grupo pra frequentar, é...faz uma atividade fora de casa..." aí deu um monte de coisas pra eu... que eu poderia fazer.

Ent. Tá.

DP Aí comecei, eu falei "vou correr atrás do prejuízo", aí comecei, aí tinha que ir numa fono. Aqui, a faculdade tava começando, a faculdade de fono aqui. Aí eu ia lá. Todo começo de ano queria arrumar uma fono porque é... no meu convênio tava falho, não tinha... não tava pagando fono e eu não tinha condição na época sabe? Então foi, foi difícil. Aí fala com um todo ano, falava com um, falava com outro. Até que a moça lá, a chefe lá, hoje, é... ela viu tanto a minha corrida, que ela falou com a Rosana. Falou com a Rosana "olha Rosana, tem uma senhora assim assim, aqui, a gente tá atendendo mais criança, adolescente né?" Aí a Rosana falou, ligou, falou "Manda ela pra mim", 
aí ela me ligou, mandou vir aí eu comecei a frequentar aqui. E fora o, o... a fono, eu comecei a fazer aula de canto.

Ent. Ah, que bom.

DP Porque o rapaz que... ele dá aula de canto pra mim, ele, ele fazia muita coisa de fono pra mim, sabe?

Ent. Hum hum de movimento assim...

DP Ele fazia exercício, ele me ajudou muito muito muito.

Ent. Ah que bom.

DP Sabe? Aí eu vim pra cá, aí a Rosana sempre punha uma moça pra me atender, sabe? Uma vez por semana, e eu fazendo também em casa, porque você não pode parar né?

Ent. Claro.

DP Aí comecei, comecei a fazer curso aqui, porque como eu tenho faculdade eu fazia como aluna especial, assim, os cursos mais fáceis assim, que não precisava muito empenho, né?

Ent. Sei.

DP Que...pra eu me atualizar sempre, né?

Ent. Manter a cabeça funcionando né?

DP É, então, por isso que eu to assim...

Ent. A senhora tá ótima!

DP É... muito esforço...

Ent. Não, ninguém diz...

DP Muito esforço...

Ent. É, ainda bem que a senhora teve essa força de vontade.

DP É, pelo que ele me falou. E agora eu to preocupada que tá fazendo dez anos! (risos) 
Ent. (risos)

DP Aí eu preciso voltar nele pra ele me mandar fazer uma ressonância, mas eu to com medo agora...

Ent. Não, mas não tem que ter medo, sempre é melhor saber.

DP É, mas eu to controlando a pressão sempre, tomando remédio, né? Então, é...e correndo, correndo.

Ent. É, mas não quer dizer que vai ter nada...

DP A gente tem que se prevenir.

Ent. Tem que se prevenir, mas tudo que a senhora já fez...

DP Esse senhor que você atendeu aqui por último, não sei se ele contou pra você, ele teve derrame faz pouco tempo!

Ent. Falou, ele falou, faz seis meses.

DP Ele andava cinco quilômentros por dia, ele falou pra você isso?

Ent. Não, não, mas eu vi que ele tava super bem.

DP E ele não tem problema de pressão, problema de sangue, e eu não sabia desse detalhe do sangue. É que comecei a tomar aspirina também, então sempre foi mais fino né... mas eu tenho uma amiga que... até preciso falar com a Rosana hoje, pra ver se eu consigo trazer pra frequentar o grupo, na frente da minha casa, com quarenta e nove anos, ela também teve o mesmo problema dele, de sangue grosso. Tá lá, ela pegou uma parte, ela tá conseguindo falar, mas tá com essa dificuldade, da fala e da memória né, que não sai as vezes a palavra. E o meu medo é esse...

Ent. É, tem que começar a tratar logo.

DP Então, é...

Ent. Quanto antes a senhora trazer ela aqui... 
DP Eu tenho um livro lá que eu co/ que eu comprei que eu frequentei um grupo aqui de memória que teve aqui na Unicamp... sempre correndo atrás...

Ent. Certo.

DP Aonde fala "tem isso" eu vou atrás.

Ent. É, não, tá certo a senhora.

DP Por isso que eu to assim, né?

Ent. Tá ótima. Graças a deus. Dona DP, eu trouxe um testezinho aqui pra fazer com a senhora, mas eu to achando que vai ser... dez a zero assim...

DP Não sei não...

Ent. Ah acho que não, porque a senhora falou que a senhora teve algum problema de memória assim, né, mas ele é bem simples, acho que seria mais assim pra quem tá mais...

DP Mas eu tenho (incompreensível)

Ent. Vamos ver, eu acho que a senhora vai tirar de letra, mas tudo bem. Entaõ é o seguinte, primeiro eu vou mostrar... a senhora vai achar até bobo, mas tudo bem. Eu vou mostrar umas figuras de animais pra senhora e a senhora vai me dizer os nomes deles, depois eu vou perguntar pra senhora, eu vou falar os nomes dos animais e a senhora vai dizer pra mim como eles são, tá? Então eu vou ver se a senhora consegue falar o nome e se a senhora consegue lembrar de outras características, das características mais marcantes deles. Não precisa dar grandes explicações tá?

DP Tá.

Ent. Muito bem. (mostra uma figura de uma girafa)

DP Uma girafa.

Ent. Muito bem. (mostra a figura de uma baleia) 
DP Ah, esse daí é o... como é que chama... não é golfinho é o...é o outro. Tá vendo, não é assim...

Ent. Não é assim né...

DP Não é assim, como você tá pensando.

Ent. Mas a senhora tá ótima.

DP É... ai meu deus! Eu vou lembrar! Depois.

Ent. Depois? Então vou deixar ela aqui.

DP Agora eu não lembro, não olho...

Ent. (mostra a figura de um cavalo)

DP É cavalo.

Ent. Muito bem. (mostra a figura de um elefante)

DP Elefante.

Ent. (mostra a figura de um gato)

DP Gato.

Ent. (mostra a figura de um touro)

DP Vaca. Boi né, boi, porque aqui não tem né?

Ent. Isso. (mostra a figura de uma cobra)

DP Cobra?

Ent. Cobra. (mostra a figura de um porco)

DP Porco.

Ent. (mostra a figura de uma tartaruga)

DP Tartaruga.

Ent. E o último. (mostra a figura de um burro) 
DP Esse aí é bezerro né? Não, não é, é... pônei, não é pônei. É...lá do nordeste... ai meu deus... trabalhei lá, ele ficava na janela do meu quarto! Era...jegue!

Ent. Jegue? Tem um outro nome. "Jegue" serve também, mas só pra ver se a senhora lembra o outro nome, que é mais comum. Pelo menos aqui em São Paulo é mais comum.

DP É... esqueci agora. Não vou lembrar.

Ent. Não?

DP Não.

Ent. Burro.

DP É o burro, isso.

Ent. Agora a gente vai voltar praquele lá que a senhora não lembrou.(mostra a figura de uma baleia)

DP Ai, como é que é... humm...

Ent. Mas a senhora sabe qual que é e só não lembra o nome.

DP Não, eu sei qual que é, eu sempre compro peixe aí o meu marido fala “esse daí é..." é do mar... não lembro.

Ent. Mas esse não é aquele que morde.

DP É, esse é.

Ent. Não, esse daqui não era pra ser esse, não. Esse era pra ser o outro que é mais bonzinho.

DP Ah, então é o peixe, comum.

Ent. Comum não.

DP Não é... tem o golfinho, não é né? É golfinho, não é?...

Ent. Baleia.

DP Baleia. Mas a baleia morde. 
Ent. Morde?

DP Morde.

Ent. É que eu pensei que a senhora tava pensando em tubarão.

DP Não, não, baleia.

Ent. Porque a senhora falou que vai na feira e tal, porque tem gente que compra...

DP Não a gente compra aquela... aquela...é... aquele pedaço do peixe que o meu marido fala "isso daí é tubarão".

Ent. É. Cação, né?

DP É, cação.

Ent. Então tá bom. Então agora sem olhar dona DP eu quero saber se a senhora sabe dizer pra mim, as características...

DP Deixa eu ver...

Ent. Não, eu vou falar, não tem problema, não precisa lembrar. Mas eu quero ver o que a senhora lembra das características... não precisa ser coisas que a senhora viu aqui, pode ser coisas que a senhora lembra desses animais.

DP Desses animais...

Ent. Tá? Então primeiro foi a girafa.

DP Isso. A girafa ela é todinha...é... ela tem os desenhos né? E ela é alta, o pescocinho fino e é bem alta. A girafa.

Ent. Bem alta, ótimo. E como é que é a baleia?

DP A baleia aí, a gente, eu misturo baleia com tubarão.

Ent. Mas sempre assim?

DP Eu não sei assim, eu acho que... porque eu já vi baleia na praia, morta.

Ent. Sério? 
DP Já, porque quando a gente tinha casa na praia, uma vez tinha uma baleia morta que ficou lá na areia, né? Então eu...é bem grande né...

Ent. Ahãm.

DP E é nesse estilo. Ela tem um negócio atrás que é que nem tubarão. Então...o tubarão parece que ele é escuro.

Ent. Sei.

DP E a baleia não, a baleia ela é mais clara.

Ent. Tá.

DP Acho que a única diferença é essa.

Ent. Entendi.

DP Entendeu?

Ent. Tá, tudo bem. Aí o terceiro animal que eu mostrei pra senhora foi o cavalo.

DP Cavalo. O cavalo, teve uma época que eu pintava... de tudo. Depois eu fui fazer um curso de... de pintura de quadro. Eu pintei um cavalo, acho que aquele dia eu tava inspirada, nunca mais. Mas eu mesma fique boba de ver, a cara do cavalo, ficou lindo! E eu dei pra uma sobrinha. O meu marido falou "fica com ele, faz outro", eu falei "eu não vou conseguir fazer um igual a esse não! Hoje eu me arrependo de não ter ficado com o cavalo...

Ent. É um bicho muito, muito bonito de desenhar, né? Porque ele tem umas formas...

DP Muito, muito. O cavalo é um... eu acho que é um animal assim...tipo cachorro. Se ele não fosse tão grande a gente ficava com ele até dentro de casa.

Ent. O tempo inteiro. Eu acho bonito o cavalo.

DP É muito dócil...

Ent. E fala pra mim como é que ele é. 
DP Ele tem crina...tem o rabo também, comprido. É grande, alto. E vai... que mais que eu posso falar... lá perto da chácara tinha muito cavalo. E são dóceis sabe?

Ent. Ahãm.

DP Tem alguns que são mais ariscos, mas a maioria é dócil, pode chegar perto, dar coisa... eles vinham, pulavam a minha cerca, eu dava pão pra eles. Sabe?

Ent. Ahãm, sei.

DP Então é tipo assim, se fosse menor, seria cuidar dentro de casa.

Ent. Bichinho de estimação né?

DP Bichinho.

Ent. Muito bem. E dona DP, como é o elefante?

DP Ah, o elefante... elefante é um animal já que dá medo da gente, ele tem...é muito grande,é... tem aquela tromba ali que eu não chegaria perto não. Também é... ele causa medo na gente.

Ent. Ahãm. Por quê?

DP Acho que pelo porte dele, pela... a falta de conhecimento da gente também, e de ...e muitas vezes sem acontecer nada ele atacar o próprio cuidador dele, né? Então... a gente tem um certo medo. Eu tenho, pelo menos.

Ent. Tá. Ótimo, e como é... o gato?

DP Ah, o gato. Eu tinha uma gata, deixei a minha gata lá na chácara, tenho até hoje, sinto tanta falta dela. Aí era... ela era linda, ela...é, aquela raça, não é angorá, a outra...

Ent. Persa?

DP Hã?

Ent. Persa? 
DP Não. Aquela outra que é...é mais assim pro marrom...

Ent. Ah... que tem o olho azul?

DP Tem. Eu esqueci.

Ent. Siamês.

DP Siamês. E ela, as patinha dela era tudo marronzinha, parecia que ela tava de meia.

Ent. Ah que gracinha.

DP Era a coisa mais linda. Mas a gata, ela escolhe o dono né?

Ent. Ah já ouvi dizer.

DP Ela tem essa característica, e ela só aceita assim ficar perto do dono. A minha gata era muito arisca, se chegava gente estranha na casa, ela sumia. Ela só aparecia depois que ia embora ou que ficava todo mundo quieto.

Ent. (risos)

DP É verdade. E ela vinha, comia, e saía, ela não ficava por ali é... era fora de série. Ei tive que deixar ela lá, porque como ela foi acostumada solta lá, se eu trouxesse pra cá, ela ia ter que ficar presa e se soltasse ela, ela ia sumir...

Ent. Fugir né..

DP Então tive que deixar lá. Mas gato é um animal, muito de estimação. Tem pessoas que não gostam, mas são muito amorosos, tanto quanto o cachorro. E se impõem... ela se impunha na frente do cachorro, o cachorro ficava quietinho perto dela.

Ent. Que danada.

DP É, porque foi criado junto ali, então eles respeitavam ela e ela eles. Brincavam né...

Ent. Quando cria desde pequenos eles ficam assim né? Muito bem, e dona DP, como é que é o boi? A senhora cresceu em São Paulo, né? 
DP Cresci...não. Eu trabalhei em São Paulo. Eu cresci...eu nasci em Piracicaba, depois vim aqui pra Campinas, estudei aqui, trabalhei aqui, depois é que eu fui pra lá. Pra São Paulo. Então...

Ent. Então bicho de fazenda assim a senhora conhece bem.

DP Conheço. O boi... o boi tem também característica... depende também muito de como você cria ele. Ele...é arisco também...ele... a gente não chega muito perto também né, porque geralmente quem cria é pra matar né, ou pra dar leite, então não tive muito contato com boi não, só... muito pouco.

Ent. Tá, mas tá bom já. Como é que é... o porco?

DP O porco... quando eu era criança, meu pai trazia uma leitoa no fim do ano, e matava. Mas aí era uma choradeira porque ele trazia dois, três meses antes do Natal. E a gente tinha... morava numa casa com um quintal bem grande, e a gente brincava. Sempre ele trazia porco oou... cabrito.

Ent. Ahãm.

DP Ah, a gente brincava, e quando tinha que matar, ele que matava no quintal. Aí ele falava pra minha mãe "leva todo mundo embora, que hoje eu vou matar". Mas a gente chorava "não, não mata...". Depois comia né? (risos)

Ent. Queria cuidar...é! (risos)

DP Mas é muito...

Ent. É que dá dó, né?

DP Dá dó.

Ent. Ainda mais esse negócio de trazer antes, você fica vendo o bichinho lá...

DP É, dá dó né, mas olha... era uma trsiteza no dia que ia matar.

Ent. Mas mesmo o porco? Porque o cabritinho eu entendo, é um bichinho bonitinho, assim... 
DP Grita, né? O porco, nossa senhora, que judiação. Porque ele não matava quando era porco, era leitãozinho ainda, sabe? Leitoa... então é... corria no quintal ainda, né? Porque quando é porco aí sim, nem chega muito perto né? Mas era leitoa então a gente pegava... acostumava com ele... o quintal era grande...

Ent. Então o que que a senhora se lembra deles quando eles eram...vivos. (risos)

DP Lembra assim em que sentido?

Ent. Como que é um porco, assim, descreve pra mim, faz de conta que eu nunca vi um.

DP Ah, o porco tem aquele focinho redondado assim. É baixinho, barrigudinho, né? Mas, se você trata ele como animal caseiro, é como se fosse um cachorro. Mesma coisa. Ele obedece, mesma coisa. É lógico que se você for num lugar que tem criação é diferente né? Porque aí ce tem que ficar... porque aí eles são arisco. Mas ele fica bem dócil quando você tem ele em casa.

Ent. Entendi.

DP Entendeu?

Ent. Entendi. E fala pra mim dona DP como que é a tartaruga?

DP Tartaruga eu nunca tive muito contato com ela, então...

Ent. Mas só o que você sabe assim...

DP O que eu vejo é que... a minha amiga tem tartaruga, ela fala que... anda lá pela casa dela, mas eu num... só o que eu vejo é aquela carapaça né... e por baixo... mas eu tenho um certo medo.

Ent. Sério?

DP Por isso que eu não chego muito.

Ent. Medo de tartaruga? 
DP Não é que é medo, é assim... é que eu nunca fui chegada com ela, então a gente tem uma certa restrição. Pode até ser que se eu tiver uma, eu pegue amor, mas por enquanto não tá nos meu programa. (risos)

Ent. Entendi, então a característica principal que a senhora vê na tartaruga, quando a senhora pensa na tartaruga é a carapaça.

DP É, isso.

Ent. Só isso. E o último então dona DP é o burro.

DP Ah o burro é engraçado. Porque eu tive contato com o burro quando trabalhei no nordeste. Aí nós ficamos numa casa lá, e lá eles deixam tudo na rua, porque é um lugarejo que eu fiquei, sabe? Bem pobre.

Ent. Ahãm.

DP E eles andavam...o jegue, que eles falam lá né, eles andavam pela rua, pra lá e pra cá. E nós ficamos numa casa que era vizinha da delegacia, e tinha um jegue que ficava no quintal da delegacia né. Então, era uma casa a delegacia e nós ficamos numa outra casa hospedados.

Ent. Tá.

DP Aí tinha uma cerca, mas era uma cerca de arame farpado, entre a delegacia e a casa que a gente ficou. E a minha amiga, ela lavou as calcinha dela e pendurou tudo na cerca... pendurou na cerca. Aí, fomos trabalhar tudo, quando voltamos, ué... cadê as calcinha?

Ent. (risos) Ai meu deus...

DP O jegue tava lá, comeu tudo as calcinha! (risos)

Ent. (risos) Ah, que vergonha!

DP Eu falei pra ela "mas você não viu que o jegue ficava aqui?", "mas eu não sabia que ele comia calcinha!", do jeito que ele tá com fome, ele come qualquer coisa! Mas nós rimos tanto! O jegue lá... ele amnhecia as vezes na nossa janela, que era uma janela de fechar, de madeira, sabe?

Ent. Abria, ele tava lá. 
DP Ele ficava ali na calçada, porque era vizinho assim né. De manhã a gente acordava com... com... a chamada dele.

Ent. Sei.

DP Ele é engraçado, pequeninho, mas eles são bravo, não pode dar muita coisa não, chegar muito, que eles dão coice né? É esse o contato que eu tive com jegue.

Ent. Tá bom, a senhora lembra bastante e a senhora tá fingindo, que a senhora não tem nada. (risos)

DP (risos) É, tomara né.

Ent. É. Não, muito obrigada dona DP.

\subsection{Sujeito: JN}

Ent. Agora sim. Vou deixar o gravador aqui pertinho do senhor pra gravar a sua voz mais alta que a minha tá? (risos)

JN É (risos)

Ent. Então tá bom, seu JN...

JN Fala filha.

Ent. O senhor é... sabe... o senhor consegue se lembrar de nomes de animais?

JN Sei...hum...

Ent. Os nomes de animais?

JN Sei, mas eu num...agora...é...hã (risos) mas eu num sei o nome de...que...hum..., você fala "eu sei", mas...

Ent. Certo.

JN ... Não sabe falar.

Ent. O senhor sabe que animal é, mas é difícil de falar o nome? 
JN Não, não sei, não fala.

Ent. Ahãm, tudo bem, eu vou tentar aqui com o senhor então, o que é...eu vou mostrar algumas fotos, os que o senhor conseguir lembrar o nome, o senhor me fala.

JN É eu num s...eu num...é, pode, pode falar vai!

Ent. (risos) Vamo vê, o que o senhor souber, se lembrar, lembrou, senão não tem problema nenhum.

JN É, pois é.

Ent. Esse aqui.

JN Num..."xi..." “a”...num...

Ent. Tá na ponta da língua né?

JN Tá, tá, mai num... "xa”... "ja”... "ja”... hum, num... "jamá”...

Ent. Num fique nervoso! Não tem problema. Eu só to vendo...

JN Eu sei, eu sei, mas eu num falo, eu num...

Ent. É que se o senhor souber ou não souber, ainda assim vai ser útil pra entender o que tá acontecendo com o senhor.

JN É “ja” "shhh”...

Ent. Tudo bem, é um bom começo. E essa daqui?

JN Num sei... num... não, não. Não sei.

Ent. Não sabe o que é?

JN Não.

Ent. Tá. (mostra a figura de um cavalo)

JN Ca-valo.

Ent. Ah sim! 
JN Tá bom? (risos)

Ent. Muito bem. É o cavalo, ótimo. (mostra a figura de um elefante)

JN ... Eu sei, mas não sai...

Ent. Não tem problema nenhum, não to testando o senhor hein?

JN Sim eu sei. Mas eu quero, quero...

Ent. O senhor quer falar mas é difícil né?

JN É, isso, "vac"..."va"... não...

Ent. Só por esses sons que o senhor tá fazendo eu to vendo que tá... tá em algum lugar!

JN Isso, é, é, mas num s... quero f... A Iracy, uia! Saiu a palavra!

Ent. (risos)

JN Minha esposa sabe? Ela... ela, a hora que eu vou falar pra ela, nem isso eu não falo.

Ent. O nome dela?

JN É. E agora hoje, já chegou, falou... olha...

Ent. Pois é, tá vendo? Tem que puxar da memória...

JN Hum...

Ent. Eu não vou dar ajuda nenhuma porque eu quero ver como que o senhor faz pra fazer sozinho, mas depois a gente faz uma com uma ajudinha, cê vai ver como vai ficar mais fácil.

JN Ah...então cumei...cumei...humm...

Ent. Difícil?

JN Num tem jeito não...

Ent. Não tem problema... (a entrevistadora mostra a figura de um gato) 


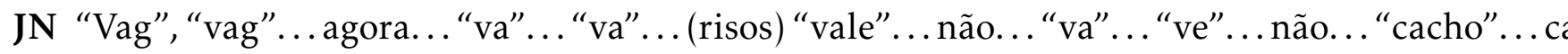
cachorro não, cavalo, não, é... num falo...

Ent. Mas, tá certo, tá certo...

JN É bom, é fala, mas num fala né? Eu queria falar! Eu quero falar! Isso num tem... mai num...

Ent. Mas tá melhorando.

JN Será?

Ent. Tá, claro que tá.

JN Acho que mei uma coisa...

Ent. O senhor não falou... ah mas vai ficar, vai ficar seu JN, o senhor não falou que nunca consegue falar o nome da sua esposa e agora saiu?

JN Hum hum, sim.

Ent. Então, devagarinho vai, dia após dia.

JN Mas já faz...já faz... dois vez, dois ano, e e e sempre vem mais um...

Ent. Mas essas coisas demoram muito seu JN...

JN Tomara que...tomara que...

Ent. Tem que ter paciência, ter fé e ter persistência, que vai melhorar.

JN “Vaj”...(risos)

Ent. Não fique nervoso, não tem problema, não, vamos pular então. ( a entrevistadora mostra a figura de um touro)

JN Tá, mais um. "Barri", é...vaca.

Ent. Vaca, ok.

JN É, vaca.

Ent. Se fosse a vaca macho? 
JN É.. va... boi!

Ent. Boi!

JN Ó! Fui bem! (risos)

Ent. Vamo vê essa daqui.

JN É..."va..." hum...tem...num...num fala também...num tem, num falo, num tem jeito de falar né!

Ent. Tudo bem. Vamos pular pra próxima. (mostra outra figura)

JN Agora é "cachorr", "ca", não...é "ca"...num fa...é... num fa... não num tem, eu num falo, não tem jeito de falar.

Ent. Não, a gente depois... eu vou voltar a gente vai fazer o senhor falar.

JN É, num falo, num jei, é...não.

Ent. Não? E esse aqui?

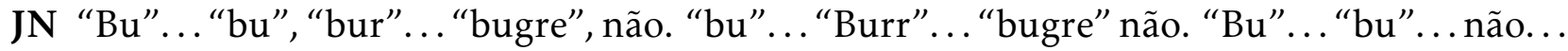

Ent. Não sai o finalzinho né?

JN Não, não falo.

Ent. Mas o começo tá certo.

JN Mas, não... não tem jeito... tá bom, mas nóis vai lá! Nóis vai!

Ent. Vamo! Tudo bem.

JN "Bugra”, não.

Ent. Por aí! O senhor não tá falando, mas tá melhorando. Seu JN, muito bem, agora a gente vai fazer um pouquinho diferente... eu vou...

JN Fala.

Ent. Eu vou apontar, eu vou colocar os desenhos na mesa e aí eu vou falar pro senhor "me aponta qual é tal", tá bom? 
JN Tá bom.

Ent. E o senhor...

JN Isto. Bom, mas só... e daí e se nóis fala, num fala.

Ent. Se nóis num fala, num fala... amanhã, aí nóis fala! (risos)

JN (risos) Tá bom, enfim...

Ent. Muito bem. Ó vou pôr de três em três, tá?

JN Isso. Esse daqui eu não lembro o nome, eu não sabe o nome dele.

Ent. Desse aqui?

JN É.

Ent. Não? Mas será que se eu falar o senhor não vai...?

JN Que é... eu sei que é de um bicho... lá, mas não fala... num s...

Ent. O senhor acha que esse daqui vai ser difícil pro senhor lembrar?

JN É. Mas eu não sei o nomes dele. O nome dela. Dele né, dele.

Ent. Hum, mas como é que o senhor sabe que é "dela" então?

JN É pois é, mas é... não...

Ent. Eu to achando que o senhor sabe hein.

JN Não...não...

Ent. O senhor tá achando que não sabe... porque é uma "ela" mesmo.

JN Hã?

Ent. É uma "ela", é um nome feminino.

JN É, mas eu num falo, né... num falei.

Ent. Hum.

JN É. 
Ent. Mas vamo vê.

JN “Cachorr", é "cachorr”...

Ent. Esse aqui é o cachorro?

JN Não, é “ca”. . eu já falei, né, hoje.

Ent. É. É “ca”...

JN “Cavalo”.

Ent. Isso é, muito bem.

JN E esse aqui é “bugre”... não, mas eu sei, eu só...

Ent. Eu vou, eu vou falar e o senhor aponta pra mim qual é e a gente vai trocando aqui vou pondo de três em três pra ver se o senhor lembra de todos os nomes, tá?

JN Tá.

Ent. Aponta pra mim a... baleia.

JN Baleia.

Ent. Essa daqui, muito bem. Certíssimo.

JN Isto.

Ent. Deixa eu ver eu vou trocar ela, colocar outro... Aponta pra mim a girafa.

JN Girafa...essa.

Ent. Muito bem. Essa daqui que o senhor tava tentando lembrar né? (troca a figura) Aponta pra mim o elefante.

JN Este aqui.

Ent. Isso. Muito bem. Agora aponta pra mim o cavalo.

JN Aqui, esse. 
Ent. Perfeito, muito bem. Aponta pra mim, o gato.

JN Gato. (aponta corretamente)

Ent. Aponta pra mim a cobra.

JN A.. eta...

Ent. Certo. Aponta pra mim o touro.

JN Sim. Isto. É.

Ent. Muito bem. Agora aponta pra mim o porco.

JN Sim.

Ent. Isso. Muito bem. Aponta pra mim a tartaruga.

JN Sim.

Ent. Muito bem. E esse último retrato o senhor lembrou agora o nome?

JN ..."b"..."bu"..."ba"...

Ent. Burro.

JN “bugre"...

Ent. Burro.

JN “Burr”... "burro”...

Ent. Isso, tava saindo, o senhor falou metade dele e parou.

JN É...é. Isso.

Ent. Agora se eu quisesse, se eu falar o nome do animal pro senhor e o senhor dizer pra mim como ele é, assim me dar algumas características...

JN Falar? Não.

Ent. Falar, mas não precisa falar muito.

JN Sim. 
Ent. Por exemplo, se eu falar assim: é.. como é que é uma girafa? O senhor consegue dizer assim uma, duas coisas sobre a girafa? Não precisa dizer muito não...

JN Não. Não sai... não fala...

Ent. Não sai, falar como ela é? Quando o senhor pensa...

JN Eu sei, mas... eu sei... mas eu num...

Ent. É difícil de falar. Hum hum, eu sei. Hum...vamo falar assim então... sem certo e errado, tá? Se eu falo girafa qual é a primeira coisa que vem na sua cabeça?

JN Gi-rafa.

Ent. Girafa. Aí...

JN Aí...falou!

Ent. Viu?

JN Girafa.

Ent. Qual é a primeira coisa que o senhor pensa se alguém falar assim "ah mas como é que é uma girafa" o senhor diria o quê? Que ela é...?

JN Hum...

Ent. Não? Não sai? Tudo bem, não tem problema. tamo só tentando né? Se eu perguntasse como é a baleia?

JN Baleia...baleia...isto é...é um...é um....como...

Ent. O que der seu JN...

JN É difícil...

Ent. Se eu mostrar a figura da girafa, será que o senhor consegue?

Girafa...Gira...grande...é... ele é... um, dois, três, quatro bo... ban...

Ent. Patas. 
JN É...pa...pa.. pa...

Ent. Patas. Ou pernas.

JN É. E...

Ent. Tá ótimo, duas coisas tá ótimo já, ela é grande e ela tem quatro patas. Tem problema nenhum. Se eu perguntar pro senhor como é um elefante, o que o senhor consegue me dizer do elefante?

JN Falar o nome...

Ent. Não precisa falar o nome dele, só quero que o senhor me diga assim, ele é... sei lá, que cor que ele é... o tamanho...

JN É grande...

Ent. Ele é grande...

JN Tem...tam.. aqui a bo...

Ent. Tem a tromba...

JN É, mas num... lá, lá, lá...

Ent. Fica ali, hum hum... o nariz dele é compridão...

JN É, isso...hum.. aqui... bã...aqui, hum...falar, é muito grande também...

Ent. A orelha é grande...

JN É, é. E mais...

Ent. Tá bom, tá ótimo, não tem problema, tá perfeito já. Que que o senhor pode dizer desse daqui? Esse daqui foi aquele que o senhor falou o nome até né.

JN Ah já não falo...

Ent. Ah fala! Tá aí, tá escondido só.

JN “Pa”..." ра".. 
Ent. "Ca"...

JN Cavalo! Cavalo! Ói que eu falo, falo, mas depois...

Ent. Precisa de um empurrãozinho né...

JN É, isso. Hum hum.

Ent. Certo...

JN Então é... um, trê, ca... quatro... vixi... quatro...

Ent. Quatro patas.

JN Pa-cas, paca...

Ent. Pa-tas.

JN Pa-ta, pata...

Ent. Isso.

JN É...e...ele fa... não.

Ent. Tem dois olhos?

JN Isto. E...hum... ficin...hum...

Ent. Focinho.

JN Ficin...é mas... ficin

Ent. Focinho.

JN Ficin, ficin, ficin...

Ent. Fo-cinho.

JN Fuuu...

Ent. Fo-ci-nho.

JN Fuzin, fucin, fucin...

Ent. Tá chegando seu JN. Só isso do cavalo? 
JN Não...bastante né! O rabo...ó! O rabo!

Ent. (risos)

JN E... agora aqui que é a... não é... agora como que...

Ent. A crina.

JN Crina.

Ent. O cabelo dele né.

JN Crina, isso. E o v... acho...hum...

Ent. Tá ótimo, tá bom, não tem problema, não vou ficar também assustando o senhor. Como é que é o...

JN Gato.

Ent. Gato! Isso.

JN Hum...Ai, difícil.

(Interrupção)

JN É...já não falo o nome...

Ent. Ga...

JN Gato, é. São bonito...é como tem as coisa, é... bonito

Ent. É bonito...

JN É...

Ent. O pelo é bonito?

JN "Po", pe mas o... (risos) é, mas o que... um, dois, assim, bonito.

Ent. As orelhas?

JN É. As menina gosta bastante dele né? (risos)

Ent. É! (risos) Eu sei que eu gosto. 
JN Qui... eu gosto né? Tá bom.

Ent. Tá bom, muito bem. Como é que é a cobra?

JN É...humm...é... eu não gosto de jeito não, mas é... ela...faz assim ó...

Ent. Rasteja...

JN É, e é muito, muito... não, ela não é não. Ela não é muito, não é.

Ent. Respira um pouquinho seu JN.

JN Mas é hein, eu quero o nome...o nome não é...

Ent. O senhor tá tentando lembrar o que ela faz?

JN É...é... ele é muito, vamo... ela não mata ninguém, ninguém...

Ent. Ela não mata?

JN Não, mas ela é... se... causo... aí ela... aí ela...

Ent. Se pegar, se ela morder... aí ela machuca...

JN Aí morre...

Ent. Ah aí morre? Ahãm.

JN É, ahãm, mas senão ela não faz nada pra ninguém...

Ent. Entendi, se não mexer com ela não faz mal.

JN É... mas aí...hum...

Ent. O senhor tem medo de cobra?

JN Eu, num...num quer né...

Ent. Num quer perto.

JN Não...

Ent. Muito bem, então tá bom. Como é que é, então, seu JN, o touro?

JN Touro...touro...é...vamos...lá...é...hum...em... 
Ent. Não? Se eu falar boi é mais fácil?

JN Como?

Ent. Como é o boi?

JN O boi é a mesma, mema... pois é mas eu quero falar! (risos)

Ent. Claro que quer, e a gente quer que o senhor fale também por isso que a gente tá forçando o senhor.

JN Ah...

Ent. Não?

JN Não...

Ent. Não tem problema, vamo pulando.

JN É bom, mas é que eu quero falar, mas não sei direito

Ent. O que eu não quero também é que o senhor se canse de ficar tentando, tentando, tentando, stressado...

JN É, não

Ent. Não tem problema, se não consguir, não conseguiu, o senhor conseguiu já os outros... não precisa lembrar todos também...

JN Que é o cach... orro, não... ca...

Ent. Não, esse aqui é como é o porco?

JN Não...

Ent. Porco.

JN Por-co. É.

Ent. Isso.

JN Então, quando é... quando ele... ela... ficinho...

Ent. Tem o focinho...hum hum... 
JN E...é... dois dois olho...

Ent. Dois olhos, hum hum...

JN Vamo...v...que...é...hum... ai num vai, num vai...

Ent. Tem o rabinho enrolado?

JN Isto...cach...e bo... bastante... bobo...

Ent. É gordinho?

JN Gor-do...é então, assim...e... hum...eu quero! Quando era, quando...falo, hummm eu quero falar, mas eu quero uma coisa...

Ent. Tem uma coisa que o senhor quer falar dele mas que tá presa aí dentro, né?

JN Mas assim é por comein mesmo.

Ent. Ahãm. Não consegue mexer?

JN Eu falava demais, demais, agora, agora...

Ent. O senhor fala bastante agora também, taí a gente tá conversando.

JN Será?

Ent. Será sim, será. Tem uma dificuldade seu JN, teve um problema, mas agora vai ficar tudo bem.

JN Eu acho que sim. É...

Ent. Eu também acho que sim. O senhor tá super bem, magina, tanta gente que tá bem pior que o senhor. Olha só, esse aqui então vamo dexá...

JN Mas é o...tá bom. (risos)

Ent. O senhor queria dizer mais alguma coisa do jeito que ele vive? Que ele é sujo?

JN Quero. (risos) É, é sim...

Ent. Que vive na lama...? 
JN É, da la...isso...

Ent. Hum hum

JN Mas eu quero falar quanto... hã... hum... e... não tem jeito né...

Ent. Não, vamo pulá. Como é que é a tartaruga?

JN Ela é boni...é...fala...hummm... ela bo, ela ma... baba va da ma...va va ma...e mas eu não v... não sei falá...

Ent. Não consegue... por gestos o senhor consegue assim falá?

JN Eu não sou ruim de de de de...falá... não, eu quero, eu quero assim... eu quero... eu to muito ruim de de de...

(Interrupção)

JN Eu sou ruim de de de falá...que, sabe...

Ent. Pronúncia? De mexer os lábios?

JN É, é, eu que... não, que, assim, eu quero falar sobr... não... não tem jeito...vamo...

Ent. Mas o senhor, o senhor encrenca um pouquinho assim na saída, mas depois o senhor...

JN Eu não entendo, eu não sou ruim de ba... muita... não é isso não, não é... não, não é...

Ent. É difícil né seu JN...

JN É, até eu, eu eu não não... não f... não falo, quero falar, não...

Ent. O senhor percebe que o senhor não tá conseguindo falar, é isso?

JN É, quanto...hum... eu quero $f .$. não não... eu quero $f .$. .

Ent. O senhor quer falar? Mas não sai.

JN Mas num ch... num sai, a minha... bom...

Ent. Devagarzinho, vai saindo, ó isso daqui realmente... 
JN Eu sei, mas num... a gente fala o que quer, jeito não é isso...hummm chégo, mas num num...

Ent. Num sai? Último bicho aí eu deixo o senhor em paz, tá? Esse aqui é o burro.

JN É essa... burro, burro, burro...e... num sai... eu num...

Ent. Que que ele faz, como é que ele é?

JN É bom pra trabalhar, trabalhar...e...hum...

Ent. E só?

JN É, eu tento mas num tem jeito né filha?

Ent. É isso que eu to querendo dizer pro senhor, eu...o senhor acertando ou não acertando, eu num quero saber quanto o senhor acerta, eu quero saber o que o senhor acerta, pra saber, né mais ou menos como estão se organizando as coisas aí dentro da cabeça do senhor pra gente poder... ajudar né... tá bom?

JN É bom...é bom...

Ent. Tá legal, muito obrigada seu JN.

JN Gostei, eu...

\subsection{Sujeito: SR}

Ent. Agora assim, vou deixar aqui pertinho do senhor pra pegar bem sua voz tá?

SR Eu eu não...falo bam não...

Ent. Fala sim! O seu JN que tava aqui antes falou a mesma coisa "ah eu não falo bem", fala, tem ué, vai devagarinho as vezes, precisa de ajuda, mas fala. O senhor sabe o que o senhor teve seu SR?

SR Eu sei, teve um derrame.

Ent. Teve um derrame. 
SR É.

Ent. Hum. Faz quanto tempo já?

SR Eu...eu não sei quanto tempo não, mas eu fiquei doente 22 de dezembo de 2005. Quantos anos eu não sei.

Ent. 2005? Hum hum.

SR Quantos eu não sei.

Ent. Quantos anos faz? Mas o senhor sabe que ano a gente tá agora?

SR É o...dez, dez.

Ent. Isso.

SR Cinco né?

Ent. Isso (risos). Muito bem. Então tá bom. E o senhor é casado?

SR Sou. Tem quatro filho, dois neto, e uma esposa.

Ent. Então tá bom, tá bom, família grande hein?

SR É.

Ent. E eles conversam bastante com o senhor?

SR Mais ou meno. Mas eu... ele... conversa mais ca a minha esposa.

Ent. Hum hum.

SR É...os filho não têm muita paciência.

Ent. É. Tem que trabalhar, aí conversa um pouquinho, já sai.

SR É.

Ent. Mas aí quando o senhor vem aqui as pessoas conversam bastante né?

SR Aqui.

Ent. Aqui né. 
SR Aqui.

Ent. Uma vez por semana, pelo menos...

SR Isso eu.... tenho tuda terça-feira

Ent. Toda terça-feira. Quem bom, tem que acordar cedinho (risos). Muito bem. Seu SR, eu to fazendo uma pesquisa sobre como as pessoas conseguem lembrar os nomes de animais. Como é que tá esse lado da memória do senhor? O senhor acha que o senhor consegue lembrar bem?

SR Acho que consigo. Bem... não muito bem, mas consigo.

Ent. Consegue.

SR Porque eu eu eu... eu vivi no sítio a infância minha tudinha.

Ent. Hum hum.

SR Por isso eu consigo lembrar, mais ou menos.

Ent. Tá, então vamo lá, então já tem uma ajuda aí né? Vamo então que eu vou fazer, vou mostrar as fotos e o senhor diz pra mim se o senhor consegue lembrar ou não.

SR A zeba né? É... Ela vive na África né?

Ent. hum hum, como é o nome que o senhor disse?

SR A zebra né. A zeba.

Ent. Tá bom. Sem problema, muito bem (mostra outra figura)

SR O tubarão né, é um peixe.

Ent. (mostra outra figura)

SR O cavalo.

Ent. Cavalo.

SR Eu andei muito de cavalo. 
Ent. É o senhor tem a ajuda aí de ter morado em sítio né. Vamos ver, tem vários animais aqui de sítio, vamos ver se o senhor lembra melhor deles então. (mostra outra figura)

SR O lefante né.

Ent. Hum hum.

SR Alefante.

Ent. Elefante. Muito bem. (mostra outra figura)

SR O gatinho.

Ent. Ah o senhor não tem problema nenhum não.

SR (risos) Tenho...

Ent. (mostra outra figura)

SR A vaca né, é a vaca...

Ent. Hum hum, se fosse a vaca macho.

SR O boi.

Ent. O boi, hum hum. (mostra outra figura)

SR Uma coba. É.

Ent. Muito bem. (mostra outra figura)

SR O porco. Matei muito porco.

Ent. Sério? Seu SR! Não dá medo não? Não dá aflição?

SR Não... mas... no títio tinha matar para comer. A gordura... a carne... tinha, necessário.

Ent. É... mas matar, né? Eles gritam...não teria coragem não, ainda bem que o senhor tem, senão não ia comer porco. E esse daqui?

SR Jabuti. 
Ent. Hum hum muito bem. Tem um outro nome?

SR Cardaru.

Ent. Tartaruga, muito bem. E esse daqui?

SR Jumentinho.

Ent. Jumentinho? (risos) Tem outro nome.

SR Burro ou não?

Ent. Burro, muito bem. Agora sem olhar as fotos, seu SR, se eu fosse perguntar pro senhor como que é cada bicho, o senhor conseguiria me descrever?

SR Ah vamo... experimentar né.

Ent. Vamo então. Então vamo vê, essa daqui, que o senhor tinha falado que era a...

SR A zeba.

Ent. A zebra. Tem certeza que é a zebra?

SR Acho que... não sei... com certeza não...

Ent. (risos) Essa daqui foi a única que o senhor errou, seu SR, essa daqui é a girafa.

SR Ah é?

Ent. É.

SR Ah!

Ent. Mas o senhor trocou só os nomes né? O senhor reconheceu que bicho que é.

SR Mas, mas eu...eu...eu... eu... eu sabia, mas falei rado.

Ent. Ahãm, mas o senhor reconheceu o animal. Tá certo. E se eu fosse perguntar pro senhor, sem olhar a foto, seu SR, como é que é uma girafa? Como é que o senhor descreveria? 
SR Eu...eu... um animal grande, pescoço muito comprido né? Alto.

Ent. Hum hum. Ótimo, muito bem. Depois esse aqui... ah esse aqui o senhor também falou errado, então só esses dois. Esse daqui o senhor falou que era um tubarão né? Não é bem um tubarão, é um outro bicho que também vive na água, que é bem grande.

SR Uma baleia, não?

Ent. Uma baleia.

SR Eu não conheço bem não viu.

Ent. Ahãm.

SR A baleia, acho que eu falei tubarão porque eu... eu fiquei na dúvida. Porque o tubarão tem o...o... mais grande assim.

Ent. Hum, tem aquela coisinha também nas costas né?

SR É, é isso.

Ent. E se eu fosse perguntar pro senhor como é uma baleia? Como é que o senhor descreveria pra mi, como é que é uma baleia.

SR A baleia, ela é o peixe maior do mar né. A -Acho que é maior, mas é muito grande, mas é... basicamente é só.

Ent. Não conhece muito né?

SR Não.

Ent. Tá ótimo, o que o senhor fez tá de bom tamanho. Sem olhar, agora como é que é um cavalo?

SR O cavalo é... o cavalo domado é ela ele é grande também, mas pode andar com ele né? Cavalo... pode andar na charrete também, né. Arado, terra, ahhh nói arava com cavalo no pormar. Pode puxar carroça. É... vérias coisas né.

Ent. Hum hum, tá ótimo como é então, seu SR, o elefante? 
SR O elefante?

(Interrupção)

SR O lefante ela... ele é natural da África, é nemal grande também. Ele... ele pode... pode... andar de cavalo também.

Ent. Ahãm, dá pra andar em cima dele também...

SR É o diano anda lá...tem um marfim valioso, né? Areia grande... mais ou menos...

Ent. Em alguns é grande em outros ela é menorzinha, né? Isso, muito bem seu SR, perfeito. E fala pra mim como é um gato.

SR O gato é um animal pequeno né? É... ele usa muito cabo de estimação, é... Véve dentro de casa...

Ent. Pode falar, vive dentro de casa...

SR Acho que é só viu.

Ent. Só? Tá ótimo, não tem problema. É, e como é que é um boi?

SR O...o boi,eu... acho que eu conheço um boi bem viu?

Ent. Ahãm, no sítio lá do senhor tinha também?

SR Ói, eu... eu carreei muito com boiada no Minas Gerais.

Ent. O senhor é de Minas Gerais?

SR Isso é. Ah e...é... a região de Pouso Alegre. É, o boi, ele faz... serve muita, para muitas coisas, ele puxa o arado, faz serviço de um trator. Mais ou menos. É um bicho grande também, banso, algumas vez rebelde também né? Mas tem, produz muita carne. Eu eu eu vou falar diferente. Eu saquesfequei muitos animais a mais na roça também.

Ent. Além do porco o senhor matava boi também?

SR Isso, também.

Ent. Nossa, mas precisa de muita força não? 
SR Não, não.

Ent. Como é que faz?

SR O.. o, o o boi tem um um...um...rom...rondondinho, ram ron rademoinho...

Ent. Redemoinho?

SR Isso, aqui aqui ó.

Ent. Na nuca?

SR Isso, você pega, finca a faca com um pouco assim, ele demonta. Até acerta o nervo aqui.

Ent. Entendi.

SR Ele ele demonta. Só pode sangrar de uma vez. Ele não po...não tem... quase força nenhum. Ele sanga e pode tirar o couro e abrir.

Ent. Entendi.

SR A...o...o...o...... os... os cara. Eu não consigo a palavra certa. Ele, ele, ele mata o boi assim.

Ent. O açougueiro?

SR Isso, é. O açougueiro distincha as peça né? Ele mais ou menos isso.

Ent. Foi uma explicação meio longa hein seu SR? Seu SR, e sem olhar, fala pra mim como é uma cobra.

SR Cobra eu também mate muito, muito.

Ent. Nesse sítio do senhor também tinha tudo hein?

SR Não, não... eu trabalhava de... a fazenda, né?

Ent. Ahãm.

SR (Incompreensível) a fazenda. Eu roça... eu roça... eu roçava pasto. É uma serra, tinha muita cascavel. 
Ent. Nossa, que perigo.

SR É. O nono da fazenda ele coscava maná tudo porque a cascavel pica os boi. Mata. Ele gostava mandá tudo as cobra que achava. A fazenda muito... muito grande, acho que... não lembo não, mas teve sim, nós cava três mês no pasto. Eu tinha o meu pai tinha cinco filho homem formado. Eu trabalhava com ele desde criança e nóis cavava junto cinco seis pessoa. Cinco... seis pessoa. Três mês por ano. Vez por outra, tudo ano, eu... ele pegava empretada para roçar o pasto.

Ent. Ahã.

SR É...fora do sítio.

Ent. Tinha a fazenda e tinha o sítio.

SR Isso. Ro... ro... roçava o pasto na fazenda.

Ent. Entendi.

SR Ele tinha muita cobra. E tem... nóis vivia porcurando também por... por isso motivo, né? Ele também purcurava ela, péla não pegar a gente também né?

Ent. Claro! Tá certo, mas o senhor falou, falou, falou, mas não explicou pra mim como é que ela é. O senhor falou que tinha cobra, que matava cobra, mas como é que ela é? Como você pode descrever pra mim?

SR Mas o... a casca-vel rela-tiva-mente...curta. Um... acho que...é um quarenta e ci...quarenta centimo mais ou meno. Mas é, mas a idade da mais véia ela é uma gossura assim. A cabeça dela é chata. É uma.... com...parecido um dó de gravata, a cabeça dela. É...tem pescocin fino e o corpo grosso, o rabo finin também. Ela tem um... um chacoalho. Eu é... nóis chamava de guizo.

Ent. Hum hum.

SR É, porque ela balançava quando tem pobrema, ela avisa para não chegar perto dela. É, ma... mais ou menos essa disquição. Ela cor rajada, também. Ao utu... utur... urutu, ele a mesma coisa, mas muito mais comprido. Mas rabo dele fino também, e ele dá muito grosso também. Mas tinha o cruzeiro...tutu cruzeiro tem uma cruz na testa dele. 
Ent. Tem uma cobra que chama cruzeiro?

SR É. Dutu. Durutu cruzeiro.

Ent. Doutor cruzeiro?

SR É...uma...durutu. Urutu.

Ent. Urutu!

SR Ele cruzeiro. Tem ferradura também. A... a... a urutu ferradura, ele tem uma ferradura na testa também, (incompreensível) ferradura.

Ent. Entendi. Muito (incompreensível). O senhor sabe tudo de bicho!

SR Tudo, tudo não, mas eu conheço um pouquinho.

Ent. Ahãm, conhece bastante e fala bem também. Tamo acabando já seu SR. Fala pra mim como é um porco.

SR O porco...e...ele... rela tive... rela tive... pequeno. É, não é muito grande não. Tem porco mais grande, mas é pequeno, né? Esse que...o granja...tem é... não passa mai de cem quilo, mais ou meno cem quilo. Ele engorda e...ele...ele dá muita carne, gordura, é o...é o...baixo, e... a cabeça dele pequeninha também.

Ent. Ahãm, muito bem, e como é que o porco vive?

SR O...vive o sorto ele vive... ele é domes-ticado né? Ele pode vive no campo, mas a granja, porco de granja, esse que nóis come, é...é... fica confinado.

Ent. Ahãm, entendi. E a tartaruga, como que é a tartaruga.

SR Não conheço.

Ent. Não conhece tartaruga?

SR Eu, eu vi, mas não não... ela... vive na h-água, né? Ela cria...eu eu conheço por televisão.

Ent. Ahãm. 
SR Ela, ela cria na areia, põe o ovinho dela na areia e... quando é nasce, ele, ela vai po mar. Vai, vive no mar, quantos ano não sei, mas acho que ela véve muitos ano, né?

Ent. Tá ótimo, muito bem. E o último, seu SR, como é que é o burro?

SR Burro, o burro ela... ele... ela nemal de andar a cavalo também né? Ele... puxa a carroça, o arado, a charrete, tem que ter muito, deverso fazer com ele. Mas eu não tem conhe-cimento ele. A carne dele acho que não come não, eu não conheço... isso aí... esse nado dele né. Mas eu gozava muito do trabalho no sítio né, mas o burro chucro ele muito veolento. Ele pula né, qual o cavalo, mas menor, mas muito ruim.

Ent. Ahãm, ele é muito teimoso, assim?

SR Isso, é.

Ent. Seu SR, o senhor não tem problema nenhum o senhor tá fingindo! (risos)

SR (Risos).

\subsection{Segunda Parte}

\subsection{Sujeito: AA}

Ent. Hoje o que eu vou tentar fazer com você é um pouquinho mais difícil, mas a gente vai vê o que vai sair ta? Não precisa ficar nervoso se não der certo. A gente tava vendo os nomes dos animais. Que você acertou bem e tal, agora, eu vou tentar usar os nomes dos animais pra fazer uma metáfora, o que que é uma metáfora? É assim, quando você fala... quando você compara uma pessoa com uma coisa, tipo "A Maria é uma flor" sabe? Então quer dizer que a Maria é tão bonita, tão delicada, isso, que ela parece uma flor. Eu vou fazer isso com você, com os nomes dos bichos, aí a gente vê se você vai conseguir lembra dos nomes deles ou não, ce acha que não? Vamos ver, eu vou te mostrar de novo, as figuras que a gente viu, só pra você lembrar mais ou menos. Lembra do nome dessa daqui? 


\section{AA Girafa}

Ent. Girafa muito bem. E dessa?

AA $\mathrm{Ba}-\mathrm{La}$ ba

Ent. Baleia. Muito bem. E essa?

AA Cava La

Ent. Muito bem AA. Cavalo. E esse?

AA Hum.

Ent. Elefante.

AA (incompreensível)

Ent. Esse aqui?

AA Ne Aah...gata.

Ent. Gata. Esse daqui? Não? Boi.

AA Bo.

Ent. Boi ou touro. E esse?

AA É... Coba coba.

Ent. Cobra. Muito bem AA, tá lembrando tudo.

AA Buia. Buio não.

Ent. Porco.

AA Porco.

Ent. Esse.

AA Ah...tar...

Ent. Tartaruga.

AA Tartauga. 
Ent. E esse aqui o último?

AA Bo bo bo.

Ent. Burro.

AA Burro.

Ent. Muito bem, lembrou todos AA. Agora vamos ver se você consegue lembrar os nomes desse bichos nessas situações de você chamar uma pessoa de um bicho, quero ver se você lembra. Se não ser tudo bem, só quero ver se você consegue (risos). Você conseguiu lembrar todos os nomes, vamos ver se você consegue sem olhar as figuras. Se eu fizer, se eu falar assim, AA, é... “O João, ele é muito gordo, nossa o João é muito gordo, o João é gordo demais, o João é um..."

AA ...

Ent. Não? Desses bichos não lembra nenhum? Se eu fizer assim "O João... ele, ele é muito grosso, ele trata as pessoas mal, fica dando patada..."

AA Ah...hum não...

Ent. Isso, será que você lembra o nome? É esse mesmo que você tá falando, que você tá fazendo assim.

AA É o cava.

Ent. Cavalo, muito bem AA, exatamente isso. Agora se eu falar assim "O João é muito bonito, nossa, o João é lindo, olha como ele é bonito, o João é um..."

AA É o... ah...

Ent. Cê lembra qual é mas tá esquecendo o nome?

AA E se eu falar da Maria? Nossa a Maria é linda, a Maria é uma...

Ent. É o bo... bo... a cava. 
Ent. Cê quer ver as figuras? (risos) É que eu não queria que você visse, eu queria que você tentasse sem ver, se você não lembrar tudo bem, mas é que eu queria que você lembrasse sem ver as figuras.

AA (incompreensível)

Ent. Não? Sem olhar as figuras não vai? Tudo bem, fica calmo então, você acertou uma, tá ótimo. Se for, pensar num outro. Se eu falar assim AA: "O João é muito forte" que bicho que ele é?

AA (incompreensível)

Ent. Vamos olhar as figuras então. Vou colocar algumas figuras só perto de você, e a gente vai...ó, essa aqui você já tinha acertado né? Esse daí é o que?

AA Boo.

Ent. "O João é muito forte, o João é um..."?

AA (incompreensível)

Ent. Isso aí, você lembra o nome dele?

AA Gati...

Ent. Isso, gato. Só pra gente fazer mais um, e se eu falar que o João é muito gordo, o João é gordo demais. É um desses aqui?

Ent. Ahh, isso. Qual o nome desse daqui?

AA Bea...

Ent. Tá atrapalhando né? Isso é esse aí mesmo. Cê consegue falar o nome dele? Não? Tudo bem, não tem problema. Deixa eu tirar isso daqui que você já falou. Pronto. E se eu falar assim, se eu falar assim AA, "a Maria é muito alta, gente a Maria é alta demais, olha o tamanho dessa menina, ela é uma...?"

AA Ah... a gira...

Ent. Girafa. Muito bem, e seu falar assim AA, "a Maria é muito maldosa, ela faz fofoca dos outros, ela fala mal das pessoas..." isso, consegue? 
AA Coba, coba

Ent. Isso, que pica, traidora. E se eu falar assim AA, o... que bicho que tá faltando... se eu falar "a Maria, a Maria é muito gorda, olha, parece uma..."

AA (incompreensível)

Ent. Parece um porco? Pode ser também, e se fosse... pode ser essa daí também lembra o nome dessa daí? Nossa, a Maria é muito gorda, ela é uma...?

AA Bala...bala...baleia.

Ent. Baleia, isso, ótimo, muito bem. E se eu falasse assim AA, o João é muito sujo, ele não toma banho, o João come de boca aberta, o João é um... isso como é o nome desse daí.

AA (incompreensível)

Ent. Isso, você lembrou antes. "O João é muito sujo, o João não toma banho, o João não escova os dentes, o João é um..."

(Interrupção)

Ent. Bom, fiquei com a voz dela.

AA (Incompreensível)

Ent. “O João não toma banho, nossa o João é fedido, o João é um..." não? Tudo bem. Deixa eu tirar isso daqui. Se eu falar assim AA, a Maria, é muito lenta, nossa ela é devagar quase parando essa menina, isso, ela é uma...?

AA É...tartarua.

Ent. Isso, tartaruga. E se eu falar assim "O João não é muito inteligente não, o João é meio bobo".

AA Buo...burro.

Ent. Muito bem, quem disse que você não ia conseguir? Agora a segunda parte do teste, você quer tirar sua mochila? Tá bom, agora eu vou fazer ao contrário... 


\section{AA (interrupção)}

Ent. Segunda parte da entrevista AA, tudo bem? Ce tá cansado? Tá bom. Agora eu vou dizer o nome dos bichos pra você e você vai me dizer o que eu quero dizer quando eu falo os nomes, tá? Falando de uma pessoa, tipo "o João é um elefante, a Maria é uma girafa", tá bom? Então vamos ver AA, se eu falar "O João é um elefante" que que eu quero dizer do João se eu digo isso? Não? Então vou te dar as 3 opções, quer dizer que o João é gordo, que o João é desleixado, largadão, ou quer dizer que o João é invejoso? Gordo, desleixado ou invejoso? Não? Tá bom, vamo lá. E se eu disser, AA, "o João..."

\section{AA (incompreensível)}

Ent. Vou falar de novo, então, quer que repita? É? "o João é um elefante" quer dizer que o João é gordo, que o João é desleixado ou que o João é invejoso? Gordo...

\section{AA Hum.}

Ent. Desleixado, invejoso? Não, escapou de novo? Tudo bem, vou pular pro próximo então, se eu disser AA...tá cansado? Não? Um pouquinho? Então tá bom....

AA (incompreensível)

Ent. Cê mora longe?

AA (incompreensível)

Ent. Dois ônibus?

AA Qua ó.

Ent. Quatro horas?

AA Quatro on...

Ent. Quatro ônibus? Nossa, que cansativo AA, ainda bem que agora você tá aqui...tá descansadinho...

AA (incompreensível) 
Ent. Hum...e ainda agora tá tudo fechado lá por causa da greve, tá difícil de entrar. Vamos lá, vou fazer outra pergunta pra você, se eu disser "o João é um cavalo, nossa, o João é um cavalo..." eu to querendo dizer... o quê? Vamos ver se você consegue falar sem ajuda. "Esse João é um cavalo". Não?

AA incompreensível)

Ent. Vou dar as opções então. "O João é um cavalo" quer dizer que o João é invejoso, quer dizer que o João é grosso, ou quer dizer que o João é feio? "O João é um cavalo", grosso, invejoso ou feio? Não? Você não entende nada disso?

AA (incompreensível)

Ent. Não? Perguntar de novo? "o João é um cavalo", que que quer dizer?

AA Ca va...co...

Ent. Quer dizer que o João é invejoso, quer dizer que ele é grosso, grosseirão assim, ou feio? Não? Tudo bem no primeiro você tava acertando tudo AA, acho que os nomes dos animais é mais fácil de você lembrar né? Ó, e se eu disser "O João é um gato, nossa, o João é um gato" que que quer dizer? Não? Quer dizer...então vou dar as opções, "o João é um gato" quer dizer bonito...

AA (o celular do sujeito toca)

Ent. É seu esse celular?

AA (o sujeito entrega o celular para a entrevistadora)

(interrupção)

Ent. Muito bem, continuando. Hoje tá o dia do telefone, né AA? Vamos lá, que que a gente parou... ah, no gato. "O João é um gato", eu quero dizer que o João é bonito, eu quero dizer que o João é rico, ou eu quero dizer que o João é honesto? "O João é um gato". Não? Tudo bem, vamos pular. E se eu disser, AA, "O João é um touro. Nossa, o João é um touro"... 
AA Tou...to...

Ent. Um touro. Mas o que que eu quero dizer com isso?

AA (incompreensível)

Ent. Vou te dar as opções. Eu quero dizer que o João é engraçado, quero dizer que o João é alegre, ou quero dizer que o João é forte? "O João é um touro" quer dizer que o João é engraçado, ou que ele é alegre, ou que ele é forte?

AA (o sujeito tenta olhar as anotações)

Ent. Cê consegue ler AA? Se cê conseguir ler, é esse daqui, ó. “O João é um touro" quer dizer que o João é engraçado, que ele é alegre, ou que ele é forte. Tenta fazer só "sim" ou "não" pra mim então. "O João é um touro" quer dizer que ele é engraçado? Quer? Se eu disser que o João é um touro, quer dizer que ele é alegre? se eu disser que o João é um touro, quer dizer que ele é forte?

AA (o sujeito fez que sim para todas as opções)

Ent. Os três? (risos) Era pra escolher só um, né AA, mas tudo bem. Vamos fazer mais um, se eu disser "a Maria é uma girafa", que que eu quero dizer da Maria se eu falar isso? "Nossa, a Maria é uma girafa". Não? Vou dar as opções pra você, então...

AA (o sujeito aponta nas anotação a parte onde está a pergunta sobre a girafa)

Ent. Isso, esse mesmo, eu quero dizer que a Maria é feia, eu quero dizer que a Maria é alta, ou quero dizer que a Maria é suja? "A Maria é uma girafa".

AA Ada. Ada. Ada.

Ent. Alta?

AA Ada. 
Ent. Muito bem AA, perfeito. Agora, se eu disser "A Maria é muito maldosa, a Maria..." ai desculpa, to falando ao contrário, vou pular essa pra voltar depois. Eu que errei. Se eu disser AA, "o João é um burro, nossa o João é um burro, meu deus do céu!", que que eu to querendo dizer do João?

AA (incompreensível)

Ent. Não entendi. Vou te dar as opções, tá? Se eu disser "o João é um burro" eu to querendo dizer que ele é ciumento? To querendo dizer que ele é gordo? Ou eu to querendo dizer que ele é pouco inteligente? "Nossa, o João é burro demais", quer dizer que ele é gordo, quer dizer que ele é ciumento ou quer dizer que ele é pouco inteligente?

AA (incompreensível)

Ent. Ciumento?

AA Não.

Ent. Vou te dar as opções e você faz assim quando for a certa então, tá? Quer dizer que o João é ciumento? Quer dizer que o João é gordo? Ou quer dizer que o João não é inteligente?

AA (o sujeito fez que sim para a última)

Ent. Essa aqui? Muito bem, exatamente, "o João é um burro". Mais uma então, se eu disser, AA, "O João...", não, o João não, "a Maria é uma cobra, essa Maria é uma cobra", que que eu to querendo dizer da Maria?

AA Ah...(incompreensível)

Ent. Que ela é traçoeira? Eu vou falar, vou te dar as opções só pra ajudar, pra gente escolher uma palavra mais fácil. SE eu falar que a Maria é uma cobra, eu to querendo dizer que ela é pobre?

AA (sujeito faz gesto de não)

Ent. Se eu disser que a Maria é uma cobra, eu to querendo dizer que ela é desorganizada? 
AA (sujeito faz gesto de não)

Ent. Não. Se eu disser que a Maria é uma cobra, eu to querendo dizer que ela é maldosa?

AA (sujeito faz gesto de sim)

Ent. Maldosa? Isso, muito bem, AA, perfeito. Tamo acabando já, tá? Aí vou deixar você descansar em paz. AA, se eu disser "A Maria é uma baleia, olha só a Maria, meu deus, ela é uma baleia", eu to querendo dizer que ela é gorda, que ela é perigosa, ou que ela é mal-intencionada? "A Maria é uma baleia". Agora é esse aqui de baixo. Vou falar as opções você fala quando for a certa. "A Maria é uma baleia”, quer dizer que a Maria é gorda?

AA (o sujeito faz gesto de sim)

Ent. É? Quer dizer que ela é perigosa?

AA (o sujeito faz gesto de sim)

Ent. Também? É pra você escolher uma só. Quer dizer que ela é gorda? Ou que ela é perigosa?

AA Periga...

Ent. Ela é perigosa? É? Tá bom, e se eu disser, AA, “O João é um porco, nossa, como o João é porco, esse João é um porco", que que eu to querendo dizer, eu to querendo dizer que ele é covarde? Ou eu to querendo dizer que ele é pobre, ou eu to querendo dizer que ele é sujo?

AA A utima. Essa.

Ent. Isso, muito bem, vamos lá então, é a última tá AA, depois dessa você vai ficar em paz. Se eu disser "a Maria é uma tartaruga”, que que eu quero dizer? "Nossa, essa Maria é uma tartaruga". Eu quero dizer que ela é pouco inteligente, eu quero dizer que ela é pobre ou eu quero dizer que ela é lenta?

AA (o sujeito aponta para a resposta "lenta") 
Ent. Lenta? É? Muito bem AA, ótimo, viu, que que ce tava falando aí que você não ia conseguir lembrar nada? Muito bem, era só isso.

\subsection{Sujeito: AC}

Ent. Porque... lá em São Paulo tava super frio. Eu trouxe duas blusas.

AC Semana passada foi p... foi frio.

Ent. Foi, foi. Mas agora mesmo ainda tá um pouquinho.

AC Agora... agora tá bom, agora.

Ent. É, tá melhor um pouquinho. Muito bem seu AC, segunda parte...

AC Segunda parte.

Ent. ... da minha entrevista. Vou esconder ela aqui pro senhor não ficar... bravo. Olha só, o senhor sabe o que que é uma metáfora?

AC Que que é?

Ent. Que que é uma metáfora?

AC Hum...

Ent. Não? Não tem problema, vou explicar, uma metáfora é quando a gente vai falar, a gente compara uma coisa com outra, por exemplo, se eu falar assim "A Maria é uma flor"... eu to querendo dizer que a Maria é tão delicada, ela é tão bonita, ela é tão...

AC Não... não é que nem minha nora não...

Ent. Não é que nem sua nora? Porque a sua nora é uma flor ou não é uma flor?

AC É uma flor sim.

Ent. É uma flor?

AC Não, ao contrário. 
Ent. (risos) Ela tem espinhos então?

AC (risos)

Ent. Pois é, assim é que é então que a gente fala quando a gente fala uma metáfora, a gente fala "ah...fulano..."

AC Como é que chama?

Ent. Uma metáfora. Metáfora. Mas tudo bem, o senhor não precisa saber o nome, é só pra explicar pro senhor o que eu vou tentar fazer com o senhor agora, que é o seguinte é...eu quero saber como é que o senhor consegue usar os nomes dos animais que a gente viu na semana passada... pra fazer metáforas. Geralmente não é uma coisa muito boa né? Quando a gente chama uma pessoa de animal assim, mas... as vezes é.

AC Ahãm...ah, uma coisa que a gente conhece a gente mais ou menos sabe como que é. Agora que nem a... a... fia da mãe aí que num...eu conheço mas... do burro, vaca, essas coisas...

Ent. Isso... exatamente...

AC Isso aí eu conheço tudos eles.

Ent. Ótimo, então vamos ver como que o senhor se sai. Eu vou descrever a pessoa pro senhor e o senhor me diz que... que nome de animal que se encaixaria nela.

AC Vamo vê.

Ent. Vamo vê? Vamo vê, então tá bom. Então olha só, pra começar bem hein, seu AC se eu falar assim "A Maria é muito alta", a Maria é uma...

AC Víbora.

Ent. Víbora é alta?

AC (risos) Não, não, não...é... ai ai ai eu sei como é que fala... mas...

Ent. Não tem problema, pensa um pouquinho, fica calmo, respira... "Nossa, a Maria é muito alta, a Maria é uma..." 
AC Meu Deus do céu...eu sei como que p...eu sei como que fala esse negócio aí, mai... ai ai ai ai...hum... ai ca...é que nem o...o jogador de basquete lá...

Ent. Isso... que de alto que a pessoa é, parece uma...é uma...

AC Hum...como é que eu posso falar...?

Ent. Era bem aquela que o senhor tava falando que era difícil.

AC Hãn...

Ent. Não? Vamo, eu vou dar um tempo depois eu pergunto de novo. Vou perguntar outra coisa, tá bom? Vamo lá, se eu disser assim, seu AC, "o João...é um grosso, nossa, ele é muito, ele é estúpido, ele trata as pessoas mal, o João é um..."

AC Estúpido.

Ent. Mas eu preciso de um nome de animal.

AC Um burro.

Ent. Um burro?

AC É.

Ent. Um burro que trata mal as pessoas?

AC Nossa senhora! Quer mais burro do que burro?

Ent. (risos) Não dá né?

AC Não dá né? Não dá!

Ent. Muito bem, então pro senhor se eu falar "Nossa o João é estúpido" o João é um burro?

AC Um burro.

Ent. Tá, muito bem, e seu eu disser... mesmo pra grosso, falar "Nossa, que grosso!"...

AC Também né, mesma coisa de grosso...

$$
238
$$


Ent. Hum hum...

AC Burro, ou grosso é que... são as duas partes iguais.

Ent. Tá legal, muito bem, se eu disser, seu AC "Nossa, o João é muito bonito, nossa, o João é lindo! O João é um..."

AC Bacana.

Ent. Mas nome de animal.

AC Ah tem... nome... nome... de animal...?

Ent. Nome de animal. Quando a gente vê uma pessoa bonita, uma menina bonita ou um menino bonito, a gente fala "Nossa, olha parece um... esse menino é um..."?

AC ... posso... posso... posso... eu acho bonito também o... o... a zebra.

Ent. A zebra?

AC É.

Ent. Mas cê não fala isso, tipo, "O João é tão bonito, o João é uma zebra"

AC (risos)

Ent. O senhor acha bonito, tudo bem, tem vários animais que são bonitos, cê acha o cavalo bonito, mas tem um animal que a gente fala assim "Esse menino é um..."

AC Não sei.

Ent. É um bichinho de casa que todo mundo acha bonito.

AC Um gato... um cachorro...

AC

Ent. Mas qual que o senhor fala "Nossa o João é bonito, o João é um..."

AC Não sei.

Ent. Não? Não? O João é um gato? Já ouviu falar isso? 
AC É...é...é... João é um gato. Quer dizer...

Ent. Hum hum. O senhor falaria isso? Ou "A Maria é uma gata, nossa que bonita que ela é, a Maria é uma gata!".

AC Pois é, é uma gata.

Ent. Ahãm, o senhor falaria isso?

AC Não eu... eu faria isso aí.

Ent. Tá legal.

AC Entendeu?

Ent. Tá ótimo. Próximo. Se eu dissesse assim seu AC, “O João é muito forte"...

AC É robusto.

Ent. É, que bicho que ele é? “Nossa, o João é muito forte, o João é um... ”.

AC Elefante.

Ent. Um elefante?

AC É.

Ent. Forte?

AC É.

Ent. Muito bem, tá ótimo. Se eu disser...

AC Só que é...tem, tem algum bicho mais forte que o elefante, acho que não tem né?

Ent. Acho não, acho que não. Muito bem, ótimo. Vamo... vou deixar essa daqui pro final, que é aquela que o senhor não lembrou. Se eu dissesse assim "A Maria é muito maldosa, ela é fofoqueira, fala mal dos outros pelas costas, a Maria é uma..."

AC ... comé, tema palavra aí, mas não tá querendo... 
Ent. Então vou fazer assim seu AC, vou mostrar os desenhos pro senhor de novo, não vou falar o nome, o senhor que vai ter que lembrar o nome, mas eu vou mostrar pro senhor lembrar mais ou menos. (começa a mostrar as figuras)

AC O tubarão? Tubarão, será?

Ent. Esse aqui? Não era bem o tubarão, é outro. (mostra a figura de uma baleia)

AC É, tubarão, tubarão, isso.

Ent. Esse aqui não é bem o tubarão, é aquele mais bonzinho.

AC (risos)como que é...eu...

Ent. Baleia.

AC Baleia! Baleia!

Ent. Mas não vou falar hein, só vou mostrar! (mostra a figura de um cavalo)

AC Tá. Esse aí é o burro.

Ent. Esse aqui é o burro?

AC Cavalo.

Ent. Cavalo. (mostra a figura de um

AC Cavalo. Esse aí é o elefante.

Ent. Isso. (mostra a figura de um gato)

AC Esse aí é uma gata.

Ent. (mostra a figura de um touro)

AC Esse aí é um touro.

Ent. (mostra a figura de uma cobra))

AC Esse aqui...é uma jararaca, um urutu. 
Ent. Uma cobra.

AC Uma cobra.

Ent. Isso. (mostra a figura de um porco)

AC Esse aí é... um suíno... um porco.

Ent. Um porco, ótimo.(mostra a figura de uma tartaruga))

AC Pra mim é tartaruga.

Ent. Ótimo. (mostra a figura de um burro)

AC Esse daí é o tchútchu. O tchútchu.

Ent. Um tchútchu?

AC (risos) Um... burr... um burr... um burrico.

Ent. Um burro, ótimo, então esses são os animais. Vou voltar pra falar das metáforas agora então. Seu AC, se eu disser...é... "A Maria é muito maldosa, ela fala mal dos outros pelas costas, ela é falsa, a Maria é uma..."

AC Falsa!

Ent. Mas um desses bichos aqui. Um desses bichos.

AC Ah, um desses bichos, então deixa ver aqui qual que é... uma jararaca.

Ent. Muito bem... uma cobra.

AC Então.

Ent. Isso. Se eu disser assim seu AC, “O João não é muito inteligente, ele é meio bobo, assim, ele não é muito esperto não... O João é um..."

AC Um burro.

Ent. Um burro, muito bem. Se eu disser... "A Maria é muito gorda”...

AC Como é que eu posso falar? 
Ent. "A Maria é muito gorda, meu deus, a Maria é uma..."

AC Qual bicho que tem aqui... uma vaca pode-se dizer?

Ent. Pode ser. Não é um bicho que tem aqui, mas pode ser "uma vaca de gorda" também, pode falar.

AC É, o único, a única coisa que tem aqui de de de gorda ali é a vaca mesmo.

Ent. Hum... tinha a baleia também, mas tudo bem. Serve a vaca.

AC Tinha a baleia também.

Ent. A vaca serve também. Se eu disser, seu AC que "O João é muito sujo"?

AC Porco.

Ent. Ótimo. E se eu disser assim "Nossa! A Maria é muito lenta, ela é muito devagar essa menina! A Maria é uma...”

AC Tem, tem...um bicho-preguiça!

Ent. Poderia ser! Dos bichos que tava ali seria uma tartaruga.

AC Uma tartaruga?

Ent. Mas bicho-preguiça pode ser também.

AC É, também é.

Ent. Vou voltar praquele lá que o senhor não tinha conseguido falar. "A Maria é muito alta".

AC Ah...ah... ah... ela tem o negócio, ela tem o negócio aqui, mas não consigo lembrar!

Ent. Não, o senhor quer respirar um pouquinho, porque o aconteceu da outra vez, eu saí e o senhor falou '"ah é aquilo". Respira. "A Maria é muito alta... olha a cabeça dela vai lá em cima".

AC Tem tem, tem a palavra, mas num... mas tá difícil.

Ent. Se eu mostrar o bicho o senhor consegue apontar, será? Vou colocar... 
AC $\mathrm{O}$ coiso aqui. Esse aqui.

Ent. Esse aqui. Não lembra?

AC (risos) Ah...isso...fugiu...

Ent. Fugiu?

AC Não, eu vou lembrar...girafa!

Ent. Girafa! Muito bem, seu AC, vitória! (risos)

AC (risos) ai ai... tem coisa que num...num... a gente lembra o que é, mas...

Ent. Fica na ponta da língua mas não sai, né?

AC Exatamente.

Ent. Sei bem como é.

AC Entendeu.

Ent. Vou fazer... agora vou fazer o contrário com o senhor tá? Eu vou dizer a frase tipo assim "O João é um elefante, o João blá blá blá"

AC O João... num falei do do do João ainda.

Ent. Não falou do João?

AC Do...do... de ser alto.

Ent. Ah tá bom, "O João é alto...é muito alto...ele é uma..." O senhor tinha falado da Maria já, de ser girafa, pra mim serve.

AC É pode ser da... da girafa, também né.

Ent. É porque você pode falar "O João é uma girafa", né? Não tem problema.

AC É. 
Ent. Mesmo sendo masculino e feminino, não tem problema. Muito bem, seu AC, eu vou dizer a frase e o senhor diz pra mim o que que o senhor entende quando eu falo essa frase, tá? Então vamo lá, "O João é um elefante", que que eu to dizendo que o João é?

AC Se falar elefante... não posso falar elefante né.

Ent. É... não...é a metáfora, que nem se falar "A Maria é uma flor" o senhor entende que ela é bonita, que ela é delicada, que ela é perfumada...

AC Uma gata né?

Ent. É que ela é uma gata também. Uma gata. Então se eu disser que o João é um elefante eu to dizendo que o João é o quê? Que que tem em comum o João e o elefante pra eu chamar o João de elefante?

AC Tem, em, mas aí é que tá... num num...

Ent. Num vai?

AC Num vai...

Ent. O senhor já ouviu essa frase antes?

AC Claro que eu já vi.

Ent. Hum hum. O senhor não consegue falar, mas o senhor sabe o que é?

AC Ah...é que nem a girafa aí...

Ent. Hum hum.

AC Eu queria... eu queria ter o nome dela no papel pra mim...

Ent. Pro senhor lembrar?

AC É.

Ent. A gente escreve depois então. (risos) Vou pular esse aqui então, depois eu volto. Tá bom?

AC Filha da mãe. O João. O João. (risos)

Ent. O João. (risos) 
AC Tá que nem o Agripino, meu genro... disgranhento.

Ent. (risos) Seu genro, sua nora... se eu disser assim seu AC "O João é um cavalo"

AC É um burro também.

Ent. Mas sem ser nome de bicho agora, agora eu digo o nome de bicho o senhor me diz o que que ele faz. "Nossa, o João é um cavalo!".

AC Ah...tá difícil.

Ent. Difícil de falar? Vou pular então e fazer mais outra. Se eu disser "O João é um gato"?

AC Um gato...é que nem o burro aí. É um gato, como é que eu posso falar que o João é um gato? Não posso falar que é um gato. É uma gata?

Ent. Eu posso falar "A Maria é uma gata" também. "Nossa, a Maria é uma gata!"

AC É, também, aí...

Ent. Tô querendo dizer que ela é o quê?

AC Uma... uma bela mulher.

Ent. Muito bem. Ela é bonita, ótimo.

AC O João também é um belo... belo...

Ent. Um belo homem.

AC Um belo homem!

Ent. (risos) É.

AC Posso falar.

Ent. Pode. Tá ótimo. Então vamo lá, mais um, se eu disser, seu AC, "O João é um touro"...

AC Ah...coitado do homem... 
Ent. (risos) Que que o senhor entende se eu falar "O João é um touro"?

AC Ah...tudo ao contrário do negócio aí... não é difícil?

Ent. É difícil, por isso que eu to perguntando, se fosse fácil...

AC "O João é um touro"... "O João é um touro"...tem, tem coisa que a gente possa falar do touro, mas o que, o que que é?

Ent. O que que é? O que que é que chama mais atenção se eu falar "O João é um touro"

AC O João é um boi?

Ent. Pode ser, mas o que que é, como é que é o boi que eu to comparando o João com o boi? "Nossa, o João é um boi".

AC Não sei.

Ent. Não? Vamo pular então. E se eu disser "A Maria é uma girafa"?

AC É...uma girafa...é uma bela mulher!

Ent. A girafa é bonita?

AC É. Pra mim é bonita!

Ent. Hum hum, mas se eu falar "A Maria é uma girafa" o senhor vai pensar que ela é bonita?

AC E por que n...e por que não?

Ent. Não, não to dizendo que não, só to perguntando se é isso mesmo.

AC Pra mim é hã...uma girafa!

Ent. Hum hum.

AC Pra mim, ela é uma bonita como se fosse uma mulher bonita.

Ent. Hum hum.

AC Entendeu? 
Ent. Entendi. Vamo lá.

AC Ela é como uma girafa. Sei lá do que que é, se é isso mesmo.

Ent. Tudo bem, depois a gente volta. Se eu disse seu AC "A Maria é uma cobra".

AC Nossa senhora.

$\mathrm{AC}$

Ent. Que que eu tô dizendo da Maria?

AC Uma bela, uma bela de uma mulher. Uma bela mulher.

Ent. Ela é bela, ela é bonita também?

AC Bonita também.

Ent. Tá bom. Se eu disser "O João é um burro"?

AC Coitado do... (risos) coitado do... do... João... tá... tudo a gente tá...

Ent. Só tá levando né? (risos)

AC Tá sendo vítima né? Ai ai ai ai... "O João é um burro”... tem tanta coisa pra...burro...burro... A minha barriga tá...

Ent. Tá com fome seu AC?

AC Não, não to com fome, a minha barriga que é assim mesmo.

Ent. "Nossa o João é um burro".

AC Não sei.

Ent. Não?

AC Tá difícil.

Ent. Vamo pulá. Se eu disser, seu AC, "a Maria é uma baleia”?

AC Coitada da Maria. Coitada da Maria.

Ent. "Nossa, Maria você é uma baleia" 
AC Eu vou falar pra ela, Maria, que você é uma baleia!

Ent. (risos) Que que quer dizer isso, “a Maria é uma baleia”?

AC Tem, tem tanta coisa de...tanta coisa bonita pra falar da Maria...

Ent. Da Maria, vai chamar ela de baleia? (risos)

AC Da Maria!

Ent. (risos) Mas é só pra eu saber se o senhor tá sabendo usar os nomes de animais desse jeito.

AC Tem...tanta coisa bonita que a gente pode falar...e não vem! E não vem! Eu vou... a hora que eu chegar em casa eu vou meter o couro na (incompreensível)...

Ent. Tudo bem, vamo pulá então...

AC ... Vou falar pra ela "Vocês... você me culpou de tanta coisa na v... na vi... na minha vida né?".

Ent. Quem fez isso?

AC Vou falar pra Maria!

Ent. (risos) Coitadinha da Maria!

AC Eu tenho uma Maria lá em casa.

Ent. O senhor tem uma Maria? Quem é?

AC A minha nora.

Ent. A sua nora é a Maria? Tadinha da Maria...

AC (risos)

Ent. Não vá falar pra ela que eu chamei ela de baleia...

AC (risos)

Ent. Última coisa... não, mais uma coisa pra ver com o senhor ainda, seu AC, "O João é um porco". 
AC Puta que o pariu. O João... coitado do João, tá na área...

Ent. (risos)

AC Ah... não tem... não tem coisa mais bonita pra você falar do João é um porco?

Ent. Eu vou... eu vou dar uma pista pro senhor, eu to vendo como que o senhor consegue fazer sem pista, depois eu tento com pista. É...e se eu disser, última coisa, "A Maria é uma tartaruga"?

AC Nossa... cê... cê... coisa bonita!

Ent. (risos)

AC Tanta coisa!

Ent. Mas tem que ser os nomes de bicho, seu AC! Como é que eu vou fazer? $\mathrm{O}$ gato ainda foi bonito, mas os outros não são. E eu preciso saber como que o senhor tá fazendo pra lembrar os nomes dos bichos. "A Maria é uma tartaruga".

AC Olha Maria, vocêe é uma tartaruga fora d'água tá?

Ent. Isso, o que que quer dizer?

AC Fora d'água... ela é uma fora d'água, ela não é uma tartaruga, uma...é uma coisa fora d'água.

Ent. Um peixe fora d'água?

AC Bela.

Ent. Hum, pode ser?

AC Então. Bela. Maravilhosa. Entendeu?

Ent. Entendi. Vamos tentar com a ajuda agora. Seu AC se eu disser pro senhor "O João é um elefante" o senhor entende que o João é gordo, que o João é desleixado ou que o João é invejoso? "O João é um elefante".

AC Ele é... um elefante... não, o elefante ele não tem nada de de de hum... 
Ent. O João é gordo, o João é desleixado ou o João é invejoso?

AC Ah...invejoso, lá...

Ent. Invejoso?

AC Invejoso não é não, porque ele é bastante inteligente, ele é.

Ent. Então qual?

AC Ele é bastante inteligente, ele é.

Ent. Mas dessa opção aqui que eu tô dando pro senhor? "O João é um elefante, nossa, olha o João, ele é um elefante!” Ele é gordo, desleixado ou invejoso qual o senhor acha que se aproxima mais do elefante?

AC Vamo gordo então né.

Ent. Gordo? Tá, mas o senhor, o senhor não acha muito normal isso, se eu dissesse "O João é um elefante o senhor não ia entender muito fácil?

AC Não, porque ele é gordo, mas é feio.

Ent. Ahãm...entendi...

AC A pele dele é tudo cheia de...

Ent. Ahãm... enrugada... grossa...

AC Grossa pra caramba...

Ent. É... muito bem... seu AC, se eu disse "O João é um cavalo", o senhor vai entender que o João é invejoso, que o João é grosseiro ou que o João é feio?

AC É feio. Feio.

Ent. O cavalo é feio. O João é um cavalo, o João é feio.

AC É feio. Mais ou menos feio.

Ent. Vou falar de novo então, "O João é um cavalo", o João é invejoso, O João é grosso, ou o João é feio? 
AC Olha... tan, to..., de tudo isso que você falou não tem nada de bonito aí.

Ent. Nada disso, mas quando você fala que uma pessoa é um cavalo geralmente você tá querendo ofender, né? "Nossa, você é um cavalo'!'.

AC Então, o...o...cavalo então né, vamo lá...

Ent. Isso, isso... invejoso, grosso, ou feio?

AC Grosso.

Ent. Grosso. Ótimo, muito bem.

AC Porque de...de...

Ent. Dá patada, né?

AC Dá patada, é.

Ent. Dá coice. Se eu disser, seu AC que o João é um gato, o senhor vai entender que ele é bonito, que ele é rico ou que ele é honesto?

AC Bonito. Bonito.

Ent. Bonito. Muito bem, se eu disser...

AC É, não é? É, porque ele sendo rico, vai querer...

Ent. Não quer dizer que ele é gato?

AC É, não é.

Ent. Também acho. Muito bem, se eu disser "O João é um touro" O senhor vai entender que o João é engraçado, que o João é alegre ou que o João é forte?

AC Ele é engraçado.

Ent. Um touro? Ele é engraçado?

AC É, ele é engraçado.

Ent. Tá bom. 
AC Por que tem touro que que que é inteligente pra caramba também.

Ent. Hum hum. Mas aí não tem muito a ver com engraçado.

AC Mas ele é engraçado.

Ent. Ele é engraçado?

AC É.

Ent. Tá bom. Se eu disser "A Maria é uma girafa” o senhor vai dizer que a Maria é feia, que a Maria é alta ou que a Maria é suja?

AC O quê?

Ent. "A Maria é uma girafa".

AC Hã.

Ent. Eu tô dizendo que a Maria é feia, que a Maria é alta, ou que a Maria é suja?

AC Pe...preferia que fosse alta.

Ent. Alta.

AC Suja não.

Ent. Alta, tá, muito bem. E se eu disser "A Maria é uma cobra" eu tô dizendo que ela é pobre, eu tô dizendo que ela é desorganizada ou eu tô dizendo que ela é maldosa?

AC Pobre.

Ent. Pobre?

AC É.

Ent. A cobra é pobre?

AC É.

Ent. Tá. Se eu disser "O João é um burro", eu tô dizendo que ele é ciumento, que ele é gordo ou que ele é pouco inteligente? 
AC Ciumento.

Ent. Ciumento? Burro?

AC É. Burro.

Ent. Muito bem. Se eu disser “A Maria é uma baleia”...

AC Hã.

Ent. Eu tô chamando a Maria de gorda, de perigosa ou de mal-intencionada?

AC Nossa senhora...

AC "A Maria é uma baleia".

\subsection{Sujeito: CP}

Ent. Dona CP, desculpa tirar a senhora do grupo de novo, tá? Mas é... vai ser rapindinho, tá bom?

CP Tá bom.

Ent. É o seguinte dona $\mathrm{CP}$, lembra que na semana passada eu tava tentando lembrar com a senhora dos nomes dos animais?

CP Ahãm.

Ent. Lembra né? Aí hoje eu vou fazer uma coisa que é um pouco diferente, é um pouco mais difícil, mas eu quero ver como a senhora se sai, que é o seguinte...é... a gente vai ver os nomes dos animais pra falar de metáforas. A senhora sabe o que é uma metáfora?

CP (risos) Não...

Ent. Não?

CP Eu sei, mas a gente...

Ent. Esquece né? É... metáfora é quando eu falo de uma pessoa, ou de uma coisa querendo comparar ela com outra coisa. Então se eu falar assim, por exemplo: "a Maria é uma flor", ... 


\section{CP Hum.}

Ent. Eu quero dizer que ela é tão bonita, tão delicada, tão perfumada, que ela parece uma flor, né? Então eu quero fazer isso com os nomes dos animais, e ver como que a senhora consegue se lembrar.

CP Tá bom.

Ent. Então só pra gente dar uma olhadinha, vou repassar as fotos pra senhora, só pra senhora lembrar quais animais que eram, tá? Lembra o nome dessa?

CP Ah...péra...girafa.

Ent. Tá ótimo. Dessa aqui?

CP Hum... ah...é tão aqui... ai meu... como que que é?... Mai num sei...

Ent. Não?

CP Porque que eles tão aquele... mas não sai.

Ent. Não tem problema. A baleia. E esse daqui?

CP Ca-valo.

Ent. Ótimo, e esse aqui?

CP Re... não...eu... peraí, ai... xi, não, peraí, eu sei... ai não, não sei.

Ent. Não? É o elefante. E esse daqui?

CP Gato.

Ent. Isso. E esse daqui.

CP Boi.

Ent. Muito bem. E esse daqui?

CP É... ai, eu to... peraí. Xi...é... não...si... não...

Ent. Co... 
CP Cato... ai é não, é... najia. Então não...é...

Ent. Isso aqui é uma cobra, só né, naja também, muito bem. E esse daqui?

CP ... Ai meu deus, como? Mas... muito... não sei, não sei...

Ent. Porco.

CP Ah é.

Ent. E esse daqui?

CP Não sei.

Ent. Tartaruga.

CP Ah não sei também.

Ent. E esse daqui?

CP Aqui... não... eu acho que é boi, mas se ele vai...

Ent. Parecido, é o burro.

CP Ah.

Ent. Mas a senhora tá lembrando bem, lembrou a maioria, tá ótimo. Agora é o seguinte, dona CP, a senhora tá usando esses nomes pra falar dos bichos mesmo, agora, se eu fosse pedir pra senhora falar eles como metáfora, né, fazer aquela coisa de comparar é que eu quero ver como a senhora vai se lembrar, tá? Então, por exemplo, se eu falasse assim: "O João, ele é muito gordo, ele é um..."

CP Ah...

Ent. Que bicho daqueles lá que a senhora usaria?

CP Hum hum hum...

Ent. "Nossa, olha o João, como ele é gordo meu deus! Ele é um..."

CP Hum... ai não sei, não... 
Ent. Muito difícil? Então vamo fazer uma poquinho diferente, eu vou colocar alguns animais aqui na mesa pra senhora olhar. Aí, qual a senhora achar que é, a senhora me diz. Aponta e me diz o no...tenta lembrar o nome. Tá? Vou fazer a pergunta de novo, porque eu troquei um pouco a ordem. Se eu falasse assim, dona CP, "a Maria é muito alta".

CP Aqui?

Ent. Esse daqui? Como é o nome dele?

CP Ah eu...Ca-valo, eu não sei que eu...

Ent. Se eu falar que a Maria é muito quer dizer que a Maria... eu diria que a Maria é um cavalo, porque ela é muita alta?

CP É.

Ent. É?

CP É.

Ent. Tá bom. E se eu falasse assim... "a Maria é muito gorda"?

CP Na...gir...

Ent. A girafa? Quer dizer que a Maria é muito gorda?

CP (risos) Ua gira...

Ent. Tá bom, e se eu dissesse assim, é... "O João, ele é muito grosso"?

CP Também.

Ent. Esse daqui? Como é o nome dele?

CP Ca-va-lo.

Ent. Muito bem, esse diria que o João é grosso né? Tá bom, vou tirar a folha então rapidinho.

CP O boi.

Ent. Isso. 
CP O ga-to...e elefante.

Ent. Muito bem. Vamo ver se eu falasse assim "dona CP, o... João, ele é muito bonito, o João é lindo, o João é um..."?

CP Assim.

Ent. Isso, que é o...como é nome?

CP Porc/ é... Gato.

Ent. O João é uma gato, muito bem, ótimo. E se eu dissesse assim, dona $\mathrm{CP}$,"O João é muito gordo. Nossa, o João é gordo demais, o João é um..."

CP Hum hum... será que... não sei.

Ent. Esse ou esse?

CP Não sei.

Ent. Acho que confundiu a senhora porque esses dois são meio parecidos né? Vou fazer/ vou trocar aqui um pouquinho. Depois a gente faz de novo que eu achei que ficou, ficaram parecidas. Se eu falar assim dona CP "a Maria, ela é muito maldosa, ela fala mal dos outros pelas costas, ela... faz fofoca... a Maria é uma..."

CP Hum...a...hum...ai... uma jarra. Najarra.

Ent. Uma naja? Muito bem. De novo, agora dona $\mathrm{CP}$, se eu falasse "O João é muito gordo, o João é um..."

CP Aqui no...

Ent. Tem esses três.

CP O ga...bo...

Ent. "O João é muito gordo".

CP Esse aqui também.

Ent. Hum, qual o nome? "O João é um..."? 
CP Um etefante. O... ai.

Ent. Muito bem, é isso mesmo, tá ótimo dona CP. Deixa eu tirar isso daqui...

(Interrupção)

Ent. Vamo lá dona $\mathrm{CP}$, se eu falasse assim... não gostei dessa ordem também, deixa eu trocar. Se eu falasse assim "A Maria...é muito lenta. Nossa, ela é muito devagar essa menina..." isso, qual o nome? "A Maria, é muito devagar essa menina! A Maria é uma..."?

CP Ah eu num sei nu... num... não o... eu não sei qual que é o num... num num...

Ent. Você não lembra o nome desse bicho não? Nem fazendo uma forcinha? "A Maria é muito devagar, meu deus, a Maria é uma..."

CP Nesma... então...

Ent. Podia ser esse daí que a senhora tá falando também, "lesma", mas o nome desse animal aí a senhora não lembra?

CP Não.

Ent. Não? Tudo bem.

CP Porque eu... num mais... assim... num faz...

Ent. Não? Não tem problema. Vamo pulá esse daqui, trocar por esse. Se eu falasse assim, dona CP, “o João é muito sujo. Ele não toma banho, ele não escova os dentes..."

CP Ai é... (risos)

Ent. Esse! E qual o nome dele? "O João é um..."?

CP Corco...cor...

Ent. É quase isso.

CP Por-co. 
Ent. O João é um porco, muito bem. E se eu falasse assim, dona CP "o João é muito forte"?

CP Aqui.

Ent. Tem esses dois.

CP É...eu... mas que...no, outra.

Ent. "O João é muito forte", é esse ou esse?

CP Hum...

Ent. "O João é tão forte, o João é um..."

CP Ah é...é isso mesmo... o... porco não... mai esse, não...

Ent. "O João é tão forte, o João é um..."

CP Touro!

Ent. Isso, muito bem. Agora esse último, se eu falasse assim "O João não é muito inteligente..."

CP Ah coitado dele...(risos)

Ent. Esse mesmo. "O João não é muito inteligente, não, ele é um..."

CP Ca-valo, não, não é... eu sei!

Ent. "Nossa, o João é um..."

CP Ai, eu falei... num num é, porque será? Ca-valo... não... porco não... aí esse daqui...

Ent. "Nosa João, como você é..."

CP Ca-valo...não...

Ent. É ele é parecido com o cavalo, mas é o outro.

CP Porc... não, esse aqui né... 
Ent. Esse daí é o porco, é, vou tirar daqui pra não atrapalhar a senhora, ver se você lembra melhor. "Nossa João, como você é..." "Você faz tudo errado, meu deus, como você é..."?

CP Eu sei... ahh... sai... não sai... mas que coisa... burro.

Ent. Isso! Perfeito dona CP, muito bem. Agora a segunda parte, agora eu vou fazer o contrário. Eu vou falar pra senhora os nomes dos animais e eu quero ver o que que a senhora entende... se eu chamar uma pessoa por esse nome, tá?

CP Hum.

Ent. Então, por exemplo, se eu falar assim: “o João é um elefante”, o que eu quero dizer?

CP Hum... por que vai...

Ent. Isso, por que que eu vou chamar ele de elefante? "Nossa, o João é um elefante" eu to querendo dizer o quê, do João?

CP Ah não sei não...

Ent. Não? Vou dar então três opções pra senhora tá? Se eu falar que o João é um elefante eu quero dizer que o João é gordo, que o João é desleixado ou que o João é invejoso?

CP Hum.

Ent. "O João é um elefante", gordo, desleixado ou invejoso?

CP Ah, é! Isso... tão peraí...

Ent. (risos) Agora a senhora entendeu né?

$\mathbf{C P}$ (risos) Eu...eu... mas é muito.

Ent. Quer que eu fale de novo?

CP Pode falar.

Ent. "O João é um elefante" quer dizer que o João é gordo, quer dizer que o João é desleixado ou quer dizer que o João é invejoso? 
CP Re... In-vejoso.

Ent. Invejoso? Tá bom. E seu eu disser assim dona CP "O João é um cavalo"?

CP Ah, mas não sei mais.

Ent. Não?

CP Eu num...num...num...

Ent. É difícil de entender?

CP É.

Ent. É? Não tem problema, vou tentar dar de novo as opções pra senhora, se a senhora não quiser me falar a palavra também a senhora só faz assim quando a senhora achar que é... que é a certa, tá?

CP Tá bom.

Ent. Então se eu disse que o João é um cavalo, eu quero dizer que o João é invejoso?

CP É... invejoso.

Ent. Vou dar três opções: quer dizer que ele é invejoso, que ele é grosso, grosseirão assim, ou quer dizer que ele é feio? "O João é um cavalo", invejoso, grosso...

CP Esse aí.

Ent. ...grosso? Tá bom. Se eu falar "o João é um gato" que que eu to querendo dizer? "Nossa, o João é um gato"... vou dar as opções.

CP Mas não sei.

Ent. (risos) Se eu disser o João é um gato, quer dizer que o João é bonito, quer dizer que o João é rico, ou quer dizer que o João é honesto?

CP Honesto.

Ent. Honesto? Tá bom. Se eu disser, dona CP, "O João é um touro"? Vou dar as opções... 
CP Não tá (incompreensível). Ai meu deus...

Ent. Vou dar as opções pra senhora então. “O João é um touro" quer dizer que o João é engraçado, quer dizer que o João é alegre ou quer dizer que o João é forte? Engraçado, alegre ou forte?

CP Num num...en-graçado.

Ent. Engraçado? Tá. Se eu disser assim “A Maria é uma girafa”...

CP Gi-rafa. Hum.

Ent. Eu quero dizer que ela é feia, quero dizer que ela é alta ou quero dizer que ela é suja?

CP Premero.

Ent. A girafa, que ela é feia?

CP É (risos)

Ent. Tá bom. Se eu disser assim "a Maria é uma cobra”?

CP Ai meu deus do céu...

Ent. Fica nervosa não dona $\mathrm{CP}$, eu falei pra senhora que esse era mais difícil.

CP Pois é... eu não sei como que co...te... o depois tá.

Ent. Falar as opções?

CP É.

Ent. "A Maria é uma cobra”...

CP Ah essa aqui.

Ent. É, mas eu vou dar as opções pra senhora. Quer dizer que ela é pobre, quer dizer que ela é mal organizada ou quer dizer que ela é maldosa? "Nossa, a Maria é uma cobra!"

CP Pa...é... 
Ent. Pobre...

CP Hum, num .... a pe... ah...hum, eu não sei... hum...

Ent. Eu vou dizer, a senhora só faz assim pra mim então, tá? A senhora não precisa nem falar. Se eu disser que a Maria é uma cobra, quer dizer que ela é pobre?

CP Não, é o lá...

Ent. Quer dizer que ela é desorganizada?

CP Não...

Ent. Quer dizer que ela é maldosa?

CP É, isso aí.

Ent. Ótimo, muito bem. Dona CP, se eu disser: “O João é um burro”...

CP Ho-nesto.

Ent. Quer dizer que ele é honesto? O burro é honesto?

CP Não.

Ent. Vou dar as opções pra senhora, se o João é um burro, quer dizer que o João é ciumento, quer dizer que o João é gordo ou quer dizer que o João não é inteligente?

CP Aqui, né num, aqui. Aqui, aqui, aqui.

Ent. O último?

CP É.

Ent. Ou o primeiro? Vou falar de novo, quer dizer que ele é ciumento ou quer dizer que ele não é inteligente?

CP Hum, num sei, eu... que ele é...

Ent. “O João é um burro", quer dizer que ele é ciumento?

CP Não. 
Ent. Quer dizer que ele não é inteligente?

CP É.

Ent. Isso, muito bem. Dona CP, se eu falar "a Maria é uma baleia"? Vou dar as opções. "A Maria é uma baleia" quer dizer que a Maria é gorda...

CP Ah não, só esse aqui!

Ent. É esse daqui?

CP É.

Ent. É? Então tá bom, não quer nem as outras opções?

CP Não.

Ent. (Risos) Então tá bom. Se eu disser "o João é um porco"... vou dar as opções: "o João é um porco" quer dizer que o João é pobre, que o João é covarde ou que o João é sujo?

CP Ah esse aí.

Ent. Sujo?

CP É.

Ent. Muito bem. Se eu disser...o último hein dona $\mathrm{CP}$, depois eu deixo a senhora em paz. Se eu disser "A Maria é uma tartaruga"... "a Maria é uma tartaruga" quer dizer...

CP Você já...

Ent. Vou dar as opções, "a Maria é uma tartaruga" quer dizer que ela não é inteligente, quer dizer que ela é pobre ou quer dizer que ela é lenta? A

CP qui.

Ent. Lenta? Tá bom então. Obrigada dona $\mathrm{CP}$, desculpa tirar a senhora do grupo de novo. 


\subsection{Sujeito: DP}

DP ... São Paulo.

Ent. Hum hum.

DP São Paulo é sempre São Paulo, né?

Ent. Pois é, não sei porque, é tão perto né? Fica essa... diferença.

DP É, mas eu acho falta.

Ent. Cê sente?

DP Eu sinto saudade.

Ent. Cê gostaria de voltar a morar lá?

DP Não, agora não, porque agora é muita gente né?

Ent. É.

DP No meu tempo... eu me aposentei em noventa e sete, noventa e seis e noventa e sete tava tranquilo. Eu lembro que o último trabalho que nós fizemos foi em Mogi das Cruzes, e sempre era uma grupo que ia né?

Ent. Hum hum.

DP A gente... eu saía de casa umas seis horas, mais ou menos, a pé, que eu morava ali na Bela Vista.

Ent. Sei.

DP Eu ia lá na, na Sé, ia até aquela estação lá... Carandiru.

Ent. Hum hum.

DP E o pessoal me esperava lá, e a gente pe/ a gente vazia uma vaquinha, né? Que um ia de carro e levava a gente, porque de ônibus ia demorar muito. Então a gente ia de carro até Mogi das Cruzes que a gente ficava trabalhando lá todo dia. 
Ent. Nossa, que longe né?

DP É longe.

Ent. Meu deus. E a senhora pegava o metrô de manhã?

DP Pegava.

Ent. Nossa, o metrô de manhã é uma coisa, né?

DP Não, então naquela época não era.

Ent. Ah não era?

DP Pois eu não ia a pé, ali é... era, é perigoso ali aquela região.

Ent. Agora é.

DP Mas no meu tempo era tranquilo, andava sossegado. Lógico que não era tão sossegado, mas perto de hoje... eu ia sossegado. Fazia chuva, sol... tinha o que fosse, tinha que ir né?

Ent. A pé...

DP Não é fácil.

Ent. É longinho também né?

DP É.

Ent. A senhora descia a Consolação ali?

DP Caminhava... não, eu ia lá pra Sé, porque eu morava ali na... Bela Vista, então eu pegava ali o viaduto... como que chama aquele viaduto ali? Dona Paulina, ia por trás da igreja da Sé e pegava aquela estação lá.

Ent. Entendi.

DP Lá eu pegava o metrô.

Ent. Entendi. 
DP Aí todo mundo falava "ce é doida". Eu ia daqui de Campinas, as vezes que a gente tava morando na chácara, eu ia... tinha época de laranja, eu ia com uma sacola de laranja que eu levava pra minha irmã, né? Todo mundo falava "mas ce é loca", e eu "eu vou", eu ia, tranquila.

Ent. A senhora vai visitar São Paulo ainda?

DP Agora não.

Ent. Não mais?

DP Só se for assim, de carro, né? Mas de ônibus nunca mais eu fui.

Ent. Ah muito trânsito agora.

DP Muito, muito.

Ent. Uma das coisas que me fazem querer sair de São Paulo é o trânsito.

DP A última vez que eu fui lá, eu tava fazendo um tratamento no Hospital das Clínicas, né? Aí... nós fomos de carro, tinha um engarrafamento já na, na... Anhanguera. No quilômetro quinze. Eu saí sete horas de casa, oito horas, oito e meia eu estaria chegando. Sabe que horas eu entrei na Marginal?

Ent. Que horas?

DP Meio dia.

Ent. Nossa.

DP Eu esconjurei, nunca mais.

Ent. Nossa, não dá. Muito difícil.

DP Muito trânsito.

Ent. Vamos ver se começa a melhorar. Agora tão fazendo mais metrô, vamos ver se melhora um pouquinho.

DP Vamos ver com esse rodoanel a hora que...

Ent. É...o rodoanel acho que vai... 
DP Acho que é mais dois anos né?

Ent. É. Devagar, né?

DP É, que eles demoraram muito pra pensar nisso, né?

Ent. Foi... pra botar a mão no bolso também né.

DP Foi, deveria ter feito isso há muito mais tempo. Mas muito que segurou foi a turma que não queria que desmatasse né?

Ent. É verdade.

DP Isso aí segurou muito o processo.

Ent. Hum hum. Eu sou contra desmatar, mas também se precisar... porque São Paulo tem que crescer pra algum lado, porque...

DP E não vai adiantar nada, ce vai ver, porque com a quantidade de carro que tá saindo que eles tão vendendo aí, todo mundo agora tem carro!

Ent. Ainda facilita o preço, né?

DP Bastante, né?

Ent. É. Todo mundo tem.

DP É complicado.

Ent. Muito bem... Dona DP.

DP Fale.

Ent. Segunda parte da minha entrevista. Primeiro eu tinha que lembrar que eu esqueci... lembra que eu pedi primeiro pra senhora dar os nomes...

DP Isso.

Ent. E depois pra senhora descrever. Depois eu fui ouvir a entrevista, e eu vi que eu tinha esquecido de pedir pra senhora descrever a cobra.

DP Ah... 
Ent. Então...

DP O que que eu teria que falar da cobra?

Ent. Falar como ela é.

DP Bom, a cobra é... eu já vi cobra, eu não vi cobra venenosa...

Ent. Tudo bem, qualquer cobra.

DP Ela.. ela é... putz, como eu posso dizer pra você? Ela vive escondida né? Ela sempre procura ir no... no... inverno ela procura o sol, então no lugar mais quente ela vai. E... em lugar assim, em árvore, fica fechada a árvore...geralmente em bananeira.

Ent. Ah é?

DP É. Em bananeira ou essas touceira de... onde tem essa planta que a gente pega, pra fazer chá. Essas touceiras de... ai esqueci o nome. Vou, vou lembrar.

Ent. Mas é porque ela se alimenta?

DP Não, é porque ela quer um lugarzinho quente, escondido, e tem que ser escondido porque ela é arisca, né?

Ent. Hum hum.

DP Então principalmente no... assim, na área rural, você não deve ter muita touceira perto da casa porque geralmente é ninho de cobra. Bananeira principalmente, elas se infiltram ali. É isso que eu sei.

Ent. Tá ótimo. Isso é só pra eu adicionar lá nos meus dados. Agora pra começar mesmo a segunda parte, a senhora sabe como são as metáforas?

DP Metáfora?

Ent. É. Metáfora é quando ce fala assim, por exemplo...

DP Sim, isso eu sei... 
Ent. "A Maria é uma flor", ela é tão delicada, ela é tão bonita...é. Então, tem muitas metáforas que a gente faz com os nomes dos animais né?

DP Sim, é.

Ent. Então eu quero ver como a senhora tá de lembrar os nomes dos animais pra falar assim, pra falar em sentido metafórico.

DP Metáfora, tá.

Ent. É.

DP Então deixa ver...

Ent. Eu posso... eu vou perguntando pra senhora, a senhora me diz, tá? Se eu disser assim "O João é muito gordo, o João é um..."

DP Elefante.

Ent. Muito bem. Se eu disser "o João é muito grosso"...

DP Grosso...

Ent. "Nossa, ele é estúpido... ele é muito... bruto, responde mal pras pessoas..."

DP Ai...que que eu posso comparar? Agora não tá vindo na memória... estúpido... ai não tá vindo na memória, fala outro que depois eu volto.

Ent. Tá bom, vamos lá. Se eu falar assim "o João é muito bonito... o João é lindo!"

DP Bonito... um gato.

Ent. Muito bem. Se eu disser "o João é muito forte".

DP Muito forte, um touro.

Ent. Um touro, muito bem. Se eu disser "a Maria é muito alta"?

DP Girafa. 
Ent. Ótimo. Se eu disser "a Maria é muito maldosa, ela fala mal dos outros pelas costas...é fofoqueira, a Maria é uma..."

DP Cobra.

Ent. Ótimo, muito bem. Se eu disser "o João não é muito inteligente".

DP Burro.

Ent. Burro. Se eu disse "a Maria é muito gorda"...

DP Gorda, já falou, elefante.

Ent. Eu falei "o João é um elefante" agora a Maria é uma...

DP Baleia.

Ent. Ótimo. Muito bem, agora se eu disser "o João, ele é muito sujo"...

DP Sujo é...

Ent. "Não toma banho, não lava a mão, come de boca aberta, nossa...o João é um..."

DP Sujo... porco.

Ent. Ótimo. E a última, depois a gente volta praquela lá. "A Maria é muito lenta. Ela dirige devagar, ela... de manhã ela não funciona muito bem..."

DP Tartaruga.

Ent. Uma tartaruga, muito bem, ótimo. Agora vamos voltar praquela que a senhora não lembrou. Se eu disser "nossa, o João é muito grosso, nossa, ele é estúpido... rude..."...

DP Deixa eu ver que bicho que é...

Ent. "Trata as pessoas mal... nossa o João é um..."...

DP Não sei... que que poderia ser? Não to lembrada.

Ent. A senhora lembra mais ou menos os animais que a gente viu na semana passada? 
DP Lembro.

Ent. É um deles.

DP Uma anta?

Ent. Não (risos).

DP Uma...

Ent. Se a senhora não lembrar exatamente desse pode falar qualquer um que...

DP Que animal que é... ? Cobra? Não...

Ent. Mas a senhora diria isso "o João é uma cobra" porque ele trata as pessoas mal?

DP Uma naja a gente fala (risos)

Ent. (risos) Ah nunca vi... Um animal que dá coice...

DP Cavalo.

Ent. Cavalo, isso. Agora, eu testei da senhora falando, agora eu vou falar a senhora me diz de novo. Mas a senhora não é afásica, né, a gente já estabeleceu isso. (risos)

DP (risos) Ah... eu sou sim...

Ent. Mas agora eu vou fazer de novo, eu vou dizer os nomes e a senhora diz pra mim o que que a pessoa é.

DP Ao contrário.

Ent. Isso. Se eu disser "O João é um elefante"?

DP É gordo.

Ent. Gordo, isso. Se eu disser “o João é um cavalo"?

DP Malcriado.

Ent. Malcriado, muito bem. Se eu disser "o João é um gato"? 
DP É... bonito.

Ent. Se eu disser "o João é um touro"?

DP Touro... que que é o touro...é grande também...gordo...

Ent. Gordo?

DP Não, não é gordo... forte.

Ent. Forte. Ótimo, se eu disser "a Maria é uma girafa”?

DP Alta.

Ent. Alta, muito bem. Se eu disser "a Maria é uma cobra"?

DP Ah...é uma naja! (risos) Ela é fofoqueira, essas coisas...

Ent. Falsa, tal...

DP É.

Ent. Se eu disser "o João é um burro"?

DP Burro é que é não sabe nada... idiota...

Ent. Se eu disser "a Maria é uma baleia”?

DP Baleia...é gorda também.

Ent. Muito bem, se eu disser "O João é um porco"?

DP Sujo.

Ent. Muito bem, e se eu disser "a Maria é uma tartaruga”?

DP Devagar.

Ent. Devagar. Muito bem. Tá ótimo! Melhor impossível! (risos) DP (risos) Então tá bom, mas eu ainda acho que eu falhei né...

Ent. Ah mas isso eu tava falando com... 


\subsection{Sujeito: JN}

Ent. Agora sim, pronto. Espero que dure até o final.

JN Tá bom, tá bom.

Ent. Vamo lá então. Seu JN...

JN Fala filha.

Ent. Se eu disser assim "o João é muito gordo, nossa como o João é gordo, o João é gordo demais" o João é um...

JN Humm...então...quero f...

Ent. Eu sei que o senhor quer falar... respira...

JN Mas num... num...

Ent. O que sair, o que o senhor conseguir falar tá ótimo, o que não conseguir também tá ótimo, não tem problema.

JN Tudo que eu num sa, eu não falo num, num tem jeito falar!

Ent. Hum hum.

JN Eu não tem... num tem jeito de falar minha filha...

Ent. Não? Vou tentar mais uma vez "O João é muito gordo" que bicho que é gordo que eu posso imitar, que eu posso comparar com o João? "Nossa o João é gordo demais, senhor, o João é um..."

JN Hum...capai de, capai de eu começar a chorar mai num tem jeito.

Ent. Olha! Chorar não pode!

JN (risos)

Ent. Chorar não pode, engole o choro!

JN Eu quero falar, mas eu queria...tem

Ent. O senhor, daqui a pouquinho o senhor vai tá falando... 
JN Falar.

Ent. Normal, ótimo...

JN Graças a deus, mas eu num...

Ent. Se deus ajudar.

JN Hum hum.

Ent. Então por enquanto o senhor só respira fundo, não fica nervoso, o que o senhor... isso aqui é difícil! Aquilo que a gente fez da outra vez era um pouquinho mais fácil, e já não foi tão, tão fácil assim. Isso aqui é difícil, eu quero ver só o que é que sai disso daqui, não to testando o senhor pra nada, só quero ver.

JN Tá. Vá. Hum...

Ent. Vou pular esse daqui do "João é gordo"

JN O João...

Ent. Se eu disser "O João é muito grosso, nossa o João é muito grosso, ele é estúpido, ele trata as pessoas mal"...

JN Cav...

Ent. "O João é um..."

JN Um to... muito...

Ent. "Nossa, que grosso, fica dando patada...credo João! Você é um..."

JN Fala... num sei se tão...

Ent. O senhor começou a falar. Ca...

JN La...

Ent. Ca...

JN Por que que eu tô...

Ent. Eu tô vendo que tá conseguindo falar...

$$
276
$$


JN Eu qué...

Ent. Porque o senhor, o senhor falou "va" o senhor falou "ca" o senhor falou "la", eu tô vendo que a palavra tá aí na cabeça do senhor, mas ela tá embaralhada.

JN É...

Ent. Ca... “João, você é um estúpido, você é um grosso, você é um..."

JN Cava...vaga...

Ent. Não tem problema. Vamo pro próximo. Seu JN, se eu falar assim “O João é muito bonito, o João é lindo"...

JN Ainda, ainda parece que já... (risos)

Ent. (risos) Aí já é uma coisa boa né, de se dizer de uma pessoa...

JN É!

Ent. "O João é lindo, o João é muito bonito, o João é um..."

JN Po...hum...num tem jeito de falar meu deus, por quê? Por quê?

Ent. Isso aqui é difícil seu JN, fica calmo, isso aqui é difícil mesmo, eu to fazendo pra ver... chutar o balde!

JN Va...hum...

Ent. “como o João é lindo, meu deus, como o João é bonito, o João é um..."

JN Num tem jeito, minha filha, num tem...

Ent. Não? Vou pular pro próximo, vou fazer mais rapidinho pro senhor não ficar sofrendo. Se eu falar "O João é muito forte"

JN Forte...forte, muito forte.

Ent. Forte.

JN Forte...

Ent. Que animal que eu falo isso, “O João é muito forte, o João é um...” 
JN Ca, cach...(risos) não tem jeito...ca...

Ent. "O João é..."

JN Forte...

Ent. Forte!

JN Forte é...ele...num tem jeito não...

Ent. Vamo pro próximo.

JN Por que que eu...

Ent. Porque isso aqui é difícil seu JN!

JN Não é, mas não é...

Ent. Aqui eu já não to nem querendo que o senhor lembre o nome dos bichos, eu to querendo que o senhor lembre o nome do bicho e...

JN Mas eu quero...

Ent. ... lembre como o bicho é pra aplicar ele a uma pessoa. Isso aqui é bem difícil, não é fácil não, até pra pessoa quando ela tá bem, assim, é mais complicado. Então fique calmo. Não... não...

JN Eu não s... não tem jeito...

Ent. Não fique estressado. Tem jeito sim.

JN Num tá.

Ent. Tem jeito. Mais um. Seu JN, "a Maria..."

JN Maria...

Ent. “...é muito alta."

JN ... muito linda...

Ent. Alta, não linda!

JN (risos) 
Ent. Lindo era o gato.

JN Tá.

Ent. Agora aqui... a girafa... opa, falei já! (risos) "A Maria é muito alta, gente a Maria é muito alta, a Maria é uma..." não vale ler!

JN Não, num... num... eu não falo, eu não pode fa/ pode fa aqui, mas que não...

Ent. Não dá?

JN Eu não falo, eu num num...é, eu sei aquilo que é, um um uma coisa, mas eu num vi... num... nem isso, ai que...

Ent. O senhor não lê?

JN É isso, isso!

Ent. Entendi.

JN Então num jeito, num num...

Ent. Então posso deixar aqui que o senhor não vai colar? (risos)

JN Pode, pode. É, que eu num vou, num vou falar.

Ent. Não, mas eu quero que o senhor fale.

JN Tá bom, tomara tomara.

Ent. Vai dar certo.

JN Tô ruim, não não, tô ruim. Não é que vai que vai... Por que que eu fiquei doi de...?

Ent. Desse jeito?

JN É.

Ent. Mas sabe que a gente tava conversando, eu conversei com o senhor, o senhor tá muito bem, o senhor dá uma engasgada, é difícil de lembrar das palavras as vezes, mas isso tudo o senhor vindo aqui, conversando com as pessoas, devagarzinho vai melhorando. 
JN É, eu já comecei, bastante!

Ent. É...

JN Quando, a hora que eu comecei, quando eu fiquei... fiquei... quando eu fiquei...

Ent. Hum hum. Quando o senhor teve o problema a primeira vez?

JN É, eu já tava, eu já tava melhor, eu já tava, graças a deus já tô tomando... alguma coisa já tô...

Ent. Já tá lembrando né?

JN É, é.

Ent. Então, tem que continuar tentando.

JN Isso. É.

Ent. Agora aqui só porque eu to fazendo o senhor fazer coisa difícil, o senhor não vai desanimar!

JN Ah eu acabei...

Ent. Não, porque isso aqui é difícil seu JN, o senhor tá bem seu JN, não entra nessa não.

JN Tá.

Ent. Olha só, se eu disser "a Maria é muito maldosa, ela é muito maldosa, ela fala mal dos outros pelas costas, ela é ruim, a Maria é uma..."

JN ... não falo...

Ent. Não? Mas o senhor sabe que bicho é que o senhor tá pensando? O senhor tá pensando num bicho e só não consegue falar ou o senhor não consegue pensar num bicho?

JN Quero falar! Falar, eu queria falar! Porque a Maria...

Ent. Hum hum... na próxima etapa, eu vou falar os nomes e o senhor me diz. Aí fica mais fácil. 


\section{JN Será?}

Ent. Vamos ver. Ó, to acabando esse daqui depois a gente faz desse outro jeito que eu acho que vai ser mais fácil pro senhor. Se eu disser "O João é... ele não é muito inteligente. Ele é meio bobo, meio idiota assim... ele não aprende as coisas..."

JN (risos) que nem eu...

Ent. Não! Isso não tem nada a ver com o senhor! Não tem nada a ver com o senhor.

JN Graças a deus.

Ent. Graças a deus não tem nada a ver com o senhor. O senhor tá com um problema, isso aqui é uma pessoa que é meio hã... você precisa falar a mesma coisa dez vezes pra pessoa, a pessoa não entende.

JN Fala a mesma coisa, eu...é...

Ent. É. Ele não é inteligente, o senhor é inteligente, o senhor tem um problema. Quando a pessoa não é inteligente... "o João não é inteligente, então o João é..."?

JN ... (o sujeito apertou os lábios, parecendo que iria pronunciar um /b/)

Ent. Tá na ponta da língua, dá pra ver que o senhor... tá pra sair.

JN Tem...hum... não tem jeito não... por que que..?

Ent. Vamo pular. Por nada seu JN, isso aqui é muito difícil que eu to pedindo pro senhor fazer. Eu to pedindo pra ver sabe por quê? Porque tem algumas pessoas que as vezes elas conseguem lembrar o nome do bicho...e não conseguem fazer...

JN Falar.

Ent. É. E não conseguem usar elas desse jeito de falar "ah o João é burro! O João é um elefante!". A pessoa consegue lembrar o nome do bicho, mas não consegue falar que uma pessoa é assim. E tem pessoas que conseguem dizer "ah o João é um burro", mas aí você mostra a foto do burro pra ele e ele não sabe dizer que é um burro. Então eu to querendo ver onde que o senhor se encaixa nisso, entendeu? 
JN Sim.

Ent. Mas é difícil, eu sei que é. E eu não quero que o senhor fique triste.

JN É que não tem jeito. Que eu num...eu num...

Ent. Mas sabe o que que pode ser, eu poderia desistir agora e dizer "ah então o senhor não consegue", mas no "gato" o senhor falou assim (estala os dedos). "Ah é o gato", pronto.

JN É.

Ent. Então eu to vendo assim quais o senhor de repente lembra. E não tem problema se o senhor não lembrar todos os outros.

JN Todas as coisas... mas não sai...

Ent. Se sair um, se o senhor conseguir falar um, pra mim já faz diferença. Tá bom?

JN Tá...

Ent. Não fique nervoso. Não fique nervoso. Se o senhor ficar triste, eu vou ficar triste também, vai começar os dois a chorar aqui...

JN (risos)

Ent. ... Vai ser uma festa, a gente sai ali, "uuuuuhhh", eles vão falar "nossa que que ela tá fazendo?".

JN Já começou né, já chega bem.

Ent. É. Ó, mais dois, aí eu vou dizer os nomes pro senhor e o senhor me diz como eles são. Penúltimo: se eu disser "o João é sujo"...

JN Sujo...

Ent. "O João não toma banho! O João não escova os dentes, o João mastiga de boca aberta, ele é sujo, o João é um..."

JN Ah mas aí...

Ent. Respira! 
JN Ah, num...

Ent. Não? Não tem problema. O último, se eu dissesse assim "A Maria é uma tartaruga" eu to dizendo que ela é o quê?

JN Ah... a menina, que nem você, sabe? Ela, ela, ela... eu num quero ca...

Ent. Vou falar então e vou dar opções pro senhor tá? Se eu falar assim "O João é um elefante"...

JN Elefante...

Ent. Eu tô querendo dizer que o João... é gordo...

JN Grosco...gross...

Ent. Gordo...

JN Grosso...grosso...

Ent. Gordo.

JN Gordo, gordo!

Ent. Se eu disser que ele é um elefante, eu quero dizer que ele é gordo...

JN Gordo...

Ent. Ou eu quero dizer que ele é invejoso... ou eu quero dizer que ele é desleixado, largado? Qual desses quer dizer "elefante"? "O João é um elefante".

JN É que...não...

Ent. Eu vou dizer as palavras pro senhor, o senhor só me diz se é essa ou não é essa. "O João é um elefante", eu tô dizendo que o João é gordo?

JN Gordo. Grosso, gross...

Ent. Gordo.

JN Gordo.

Ent. É isso que é? 
JN É.

Ent. É?

JN Isso.

Ent. Então tá bom. Se eu disser " O João é um cavalo, nossa, o João é um cavalo!”. Eu tô querendo dizer que o João é invejoso, eu tô querendo dizer que o João é grosso, ou eu tô querendo dizer que o João é feio?

JN Gro...grosso.

Ent. Grosso, muito bem.

JN É... mais ou menos, mas foi né!

Ent. É, mas o senhor tá acertando tudo, muito bem, era isso que eu queria saber. Olha só, se eu disser “o João é um gato! O João é um gato!", eu tô querendo dizer que o João é bonito, que o João é rico ou que o João é honesto?

JN Honesto... honesto...

JN O gato é honesto?

JN Não, é...

JN “O João é um gato”. Bonito, ele é rico ou ele é honesto? Qual desses três? "Nossa, olha o João, o João é um gato!"

JN Num fa...

Ent. Vou falar de novo, não fica nervoso, seu JN!

JN Mas eu sei, eu quero!

Ent. Eu sei que o senhor quer!

JN Eu sei!

Ent. “Gato, o João é um gato!”, ou melhor, vamos mudar, porque se for a Maria vai ficar melhor pro senhor né?

JN Vai, vai. 
Ent. "A Maria é uma gata".

JN Bonita.

Ent. Aaah! Agora sim, era o João que tava atrapalhando! (risos)

JN (risos) Bonita, bonita.

Ent. Ótimo, muito bem. Se eu disser “O João é um touro”...

JN Touro...

Ent. É.

JN Bravo... bravo!

Ent. Isso... ele é bravo. Ótimo.

Ent. Se eu disser “a Maria é uma girafa”...

JN E daí... com que que eu vou chegar...

Ent. E daí? "A Maria é uma girafa” eu tô querendo dizer que a Maria é feia...

JN Feia...

Ent. Que a Maria é alta ou que a Maria é suja? “A Maria é uma girafa”. Ela é alta...

JN Alta.

Ent. Ela é feia.

JN Feia.

Ent. Ou ela é suja? Vou dar as opções, o senhor só fala se for ou se não for. "A Maria é uma girafa", quer dizer que ela é feia, sim ou não?

JN Não...

Ent. Não. "A Maria é uma girafa”, quer dizer que ela é alta?

JN Alta... e alta. E a outra? 
Ent. A outra "a Maria é uma girafa" quer dizer que ela é suja?

JN Suja...é suj... po... ai.

Ent. Respira. "A Maria é uma girafa".

JN E a outra é...

Ent. Eu tô dizendo... a primeira é... o senhor falou que não era, que ela é feia.

JN Não não é.

Ent. Então se eu disser que a Maria é uma girafa eu to dizendo que ela é alta ou eu to dizendo que ela é suja?

JN Suja...hum... pobre... po... po...

Ent. A girafa é alta ou a girafa é suja?

JN Grande. Grande.

Ent. Grande. Então "A Maria é uma girafa” quer dizer que ela é grande?

JN É.

Ent. Muito bem. E se eu disser que a Maria é uma cobra?

JN Braba...braba...

Ent. Brava? Hum hum...

JN Pode ser. Pode ser né?

Ent. Vou dar as opções pro senhor. "Brava” pode ser também, mas só pra ver quais as opções que o senhor tem aqui. Eu to dizendo que a Maria é pobre, eu to dizendo que a Maria é desorganizada ou eu to dizendo que a Maria é maldosa? "A Maria é uma cobra”.

JN Tchô ver... ah...

Ent. Vou dizer de novo. Calma seu JN.

JN Eu num vou... sou... 
Ent. Não fique triste! O senhor tá indo muito bem, o senhor acertou todos até agora. Todos. O senhor não tá conseguindo falar, mas uma coisa de cada vez. Primeiro o senhor já sabe a resposta, isso já é massa...

JN Já sabe né...

Ent. Agora, depois disso a gente vai ver como que vai fazer pro senhor falar. Uma coisa de cada vez, não fique nervoso.

JN Tá.

Ent. Mais uma vez se eu falar "a Maria é uma cobra", quer dizer que ela é pobre... quer dizer que ela é pobre? "A Maria é uma cobra"?

JN Não, não.

Ent. Se eu disser "a Maria é uma cobra", quer dizer que ela é desorganizada? Ela é bagunceira?

JN Não...

Ent. Não?

JN Nem uma, nem outra.

Ent. E se eu disser que a Maria é uma cobra, eu to dizendo que ela é maldosa?

JN Pode ser! Pode ser!

Ent. Pode ser? Perfeito, então o senhor acertou mais uma. Se eu disser " O João é um burro"?

JN Pode ser...pode ser... eu quer outra... outra...hum...é...

Ent. "O João é um burro, ih, o João é um burro", vou dar as opções pro senhor: "o João é burro" quer dizer que o João é ciumento?

JN Não...

Ent. Não. Se eu disser "o João é burro", quer dizer que o João é gordo?

JN Pode ser... 
Ent. Pode ser gordo?

JN Pode ser.

Ent. Vou dar a última opção pro senhor "o João é um burro" quer dizer que o João não é inteligente?

JN Fica...fica só no s... no no...

Ent. No primeiro?

JN Hum... pode... hum, não é assim que eu quero falar!

JN Tudo bem eu vou dizer de novo, o senhor só me diz se sim ou se não.

"O João é burro" quer dizer que o João é ciumento?

JN É...é que é um...um... num to...

Ent. Num tá entendendo?

JN Eu quero...

Ent. O senhor quer falar? Tá bom.

JN Não tem jeito! (risos)

Ent. (risos) Mas vai ter! daqui a pouquinho! O senhor diz pra mim só se é a primeira, se é a segunda, se é a terceira. Sim ou não. "O João é ciument/ O João é burro", o João é ciumento?

JN Ciumento, qual que é a outra?

Ent. Ou gordo?

JN Gordo.

Ent. Ou ele é pouco inteligente, ele não é inteligente?

JN Ele não... ele não...

Ent. Ele não é inteligente?

JN É, isso! 
Ent. Isso.

JN Ele tá um...o não, não não...

Ent. Ele é burro...é isso que o senhor quer dizer, se ele é burro ele não é inteligente.

JN Isso, não é.

Ent. Isso.

JN Ah eu não...

Ent. Eu tô calma, seu JN, o senhor tá calmo? (risos)

JN É... não, eu quero falar as coisas então não tem jeito de falar né? Então...

Ent. Mas vai ter, o senhor vai/ a gente vai devagarinho, melhorando a cada dia, com paciência. O senhor sabe que quanto mais nervoso o senhor fica é pior?

JN Ah é, claro! Pior, é pior!

Ent. Tem que ficar calmo, não deu pra falar, não deu. Daqui a pouco o senhor fala outra coisa, tem que ficar relaxado. Tá? Tá acabando já, seu JN, vou deixar o senhor em paz. Se eu disser "a Maria é uma baleia", eu to querendo dizer que a Maria é gorda...

JN Gorda... sim...

Ent. Que a Maria é perigosa, ou que a Maria é mal-intencionada? "A Maria é uma baleia"...

JN Baleia, isso agora... pode ser, pode ser isso que ela isto...

Ent. Ela é gorda...

JN Gorda...

Ent. Ou ela é perigosa, ou ela é mal-intencionada? "A Maria é uma baleia".

JN Baleia, baleia. Pode ser, pode ser né... 
Ent. Mas qual?

JN Ela é grande... então...

Ent. Um dos três: gorda, perigosa ou mal-intencionada? "A Maria é uma baleia" quer dizer que ela é gorda?

JN Não.

Ent. Não? Tá...

JN Não, pode ser, pode ser! Eu não... eu to muito... eu to muito... queria fa... quero f... não tem jeito não.

Ent. Não? Não tem problema. Eu digo, o senhor me diz se sim ou não. Se eu disser "a Maria é uma baleia", eu posso estar chamando ela de gorda?

JN Gorda...é, não.

Ent. Não?

JN É, ela é, não é...

Ent. Não tem problema, não é então? Gorda?

JN Bem, aqui cê...e a outra?

Ent. Se eu chamo a Maria de baleia, eu posso tá dizendo que ela é perigosa?

JN Não.

Ent. Não? Se eu chamo a Maria de baleia eu posso tá dizendo que ela é mal-intencionada?

JN Hum... estou, eu to com... to... to so...

Ent. Tudo bem, eu vou pular essa daqui, tá muito difícil. Fica sem resposta. Tá acabando seu JN! O senhor aguenta mais um pouquinho, eu to cansando o senhor?

JN Não não, eu quero, eu quero ajudar alguém! Você! Sabe? Eu quero, só que não tem jeito de eu ajudar. 
Ent. Tem, claro que tem! O senhor pensa, o senhor pensa que o senhor dar a resposta é que o senhor tá ajudando, não o senhor dar a resposta que tá ajudando. A gente precisa, seu JN, saber onde é que tá o problema, então quando o senhor não dá a reposta é que o senhor ajuda, sabia? Porque aí eu sei "o seu JN tem um problema pra lembrar dos nomes de animais". Porque se o senhor lembrar de tudo então, tá, muito bem, muito obrigada, tenha uma boa vida, aproveita o final de semana...entendeu?

JN Sim, mas... não...

Ent. Não fica nervoso, seu JN.

JN Fica muito, muito, muito, muito...ve...

Ent. Nervoso?

JN Bastante.

Ent. Não é fácil né? A gente sabe, mas tem que respirar fundo...

JN Não tem jeito... eu quero falar, mas não tem jeito...

Ent. É mais difícil porque eu to perguntando né? Se a gente tivesse conversando, eu acho que o senhor lembraria mais fácil do que eu ficar perguntando "seu JN, que que é isso?", aí o senhor fica mais nervoso.

JN Não sei... não sei...

Ent. Então. Então calma, é um teste isso aqui, fica mais difícil, tem muita pressão no senhor, mas eu não quero que o senhor fique nervoso.

JN Tá, pergunta.

Ent. Força! Força de touro, pro senhor! Ó, último, penúltimo, aí o senhor tá livre, se eu disser "o João é um porco"...

JN Porco...ei...

Ent. Eu to querendo dizer que ele é pobre, que ele é covarde, ou que ele é sujo? "O João é um porco".

JN Os três (risos) 
Ent. Os três? O coitado do porco é covarde, pobre e sujo? Se o senhor conseguir escolher um, eu prefiro. "Nossa o João é um porco".

JN Aí vem o cate... cate, cadê o...

Ent. As opções?

JN Não, não.

Ent. O desenho?

JN Não. É, eu sei que é, mas eu não, eu quem que ele é, ele é o...o...

Ent. O porco.

JN É, pode ser, mas não...eu, eu quero falar, mas não...

Ent. Mas não sai.

JN Não.

Ent. Então não fique nervoso, não tenta mais do que o senhor pode, fica calmo. Vou dar as três opções de novo pro senhor, quando o senhor achar que "ah, é esta", aí o senhor me fala.

JN Sim, vai.

Ent. "O João é porco".

JN Porco.

Ent. "Nossa, que porco que o João é, o João é um porco". Tô querendo dizer que o João é covarde?

JN Não.

Ent. Tô querendo dizer que o João é pobre?

JN Não.

Ent. Tô querendo dizer que o João é sujo?

JN Isso aí, é. Sujo, sei sim. 
Ent. Sujo? Muito bem, ótimo, muito bem. Última!

Ent. Vai. Seu JN se eu disser "a Maria é uma tartaruga. Nossa, essa Maria... ela é uma tartaruga". Eu to querendo dizer que a Maria é pouco inteligente...

JN Tipo... tipo eu (risos).

Ent. Não, o senhor é muito inteligente, o seu problema é outro.

JN Não, sim, vá...

Ent. Eu tô querendo dizer que a Maria é pobre ou eu to querendo dizer que a Maria é lenta? Ela é devagar. Vou falar de novo. "A Maria é uma tartaruga, nossa, essa Maria é uma tartaruga!" Quero dizer que ela é pouco inteligente... sim ou não?

JN Inteligente...ele... o...

Ent. Vamos lá, tartaruga, lembra que bicho é a tartaruga?

JN Sim.

Ent. Sim? Se eu to falando que a Maria é uma tartaruga, eu quero dizer que ela é pouco inteligente? Sim ou não?

JN É, é, isto.

Ent. Quer dizer que ela é pouco inteligente?

JN É, não s... não sabe...

Ent. Não sabe as coisas? Então eu tô dizendo que a Maria é uma tartaruga não quer dizer que ela é pobre.

JN Não.

Ent. Eu tô dizendo que a Maria é uma tartaruga, não quer dizer que ela é lenta?

JN Não.

Ent. Não? 
JN Mas e...e a outra que se... só é...

Ent. Tô querendo dizer que ela é pouco inteligente?

JN Isso, é isso.

Ent. Tá bom, muito bem. Tô anotando todas as respostas do senhor. Pronto seu JN, o senhor tá livre!

\subsection{Sujeito: SR}

Ent. Pronto, perfeito. O senhor veio pra cá moço então?

SR É. Vinte ano, fartava um pouquinho. Eu vim... agosto fizamo otobro... bem né... quinze de otubro.

Ent. Quinze de outubro é o seu aniversário?

SR É. Eu vim pra cá em agosto.

Ent. Tá, então o senhor tinha dezenove e no mês seguinte fez vinte. E por que que o senhor veio pra cá?

SR Eu... A vida na roça muito custoso, eu vim para aqui po... porcurar um emprego a mai para facilitar a vida. Porque muito difícil, não tinha estudo, não tinha profissão, não tinha nada. Eu só trabaiava na roça. para comer. Família muito grande, eu era o terceiro da família, o meu pai tinha treze filho. Tudo escadinha.

Ent. Nossa.

SR E tem que, tinha que trabalhar muito para su(...)tentar ele todos né.

Ent. Imagino, e o senhor veio pra cá e começou a fazer o quê?

SR Eu eu... de verdade, eu vim eu trabalhar de servente de pedreiro, eu não tinha nada, perfissão, nada, eu não tinha conhecimento... de servente de pedreiro, eu não tinha. Eu só, só trabaiava na roça, só. Plantar, colher, arar terra, serviço de roça né. Aí eu vim pra cá, tinha começado a Unicamp, a Petrobrás tava no fim, mas tinha muito emprego lá. Eu vim para cá pra trabaiar de empregado. 
Ent. Hum hum. Aí o senhor começou a trabalhar aqui na Unicamp então.

SR O primeiro serviço meu foi na Unicamp, mas a empreiteira de terceiro. $\mathrm{Eu}$, eu comecei a (...) aqui na Unicamp abrindo a vala para fazer alicerce.

Ent. Trabalho duro né? E o senhor fez isso a vida inteira? Trabalhou com construção?

SR Não, eu trabalhei um pouco na construção no fim, na jornada minha. Eu tirei uma profissão de encanador dustrial. Servia a indústria. Eu trabalhei vinte e duas firma. Eu passei dirigir... presidir a profissão de cavador...cavador...(...), mecânico...eu fui subindo, eu...eu trabalhei de mestre, supervisor, contra-mestre, mestre, rencarregado, supervisor e sistente ténico. Eu não fui a ténico porque não tinha estudo.

Ent. Mas todo o resto o senhor sabia fazer?

SR Tudo isso é...é. Tudo isso é de do... o quarto ano de escola, na roça também. Mas eu fiz um supletivo de segundo grau, né? Mas eu parei porque eu não consegui passar nas... disciplina de português.

Ent. Ah não acredito! Bem de português? Ah não, seu SR!

SR O português e inglês. Eu não peguei o diploma porque não passei.

Ent. Bem essas duas. Que a gente estuda mais aqui.

SR Tudo a noite... que eu tava...

Ent. Trabalhando ainda né, é difícil trabalhar e estudar né?

SR É.

Ent. Eu sei bem como é. Muito bem. Seu SR, lembra que na semana passada eu tava conversando com o senhor sobre os nomes dos animais né?

SR Hum hum. 
Ent. Então, hoje eu vou falar de novo dos animais que a gente tinha conversado semana passada, mas eu vou fazer um pouquinho diferente. O senhor sabe o que é uma metáfora?

SR Não.

Ent. Não né, já que o senhor não gostava de estudar português né? (risos) Metáfora é assim... quando eu falo, deixa dar um exemplo pro senhor "nossa, a Maria é uma flor" sabe assim, de falar "ela é tão bonita que ela parece uma flor, ela é tão delicada..."

SR Isso, isso.

Ent. ... que ela parece uma flor", né? Aí tem vários jeitos de a gente fazer esse tipo de linguagem com os animais. Geralmente não é coisa boa, é você xingar a pessoa de alguma coisa, mas as vezes não é tão ruim. Então eu quero ver como que o senhor se lembra desses nomes de animais agora mas pra falar de metáfora. Tá bom? Vamos ver como o senhor se sai.

SR Acho que não vou sair bem não...

Ent. O senhor acha que não? mas o senhor foi super bem quando foi pra nomear não foi? Só que assim, eu não to pretendendo mostrar as fotos pro senhor de novo não, mas se precisar eu mostro, tá bom? Então tá bom, seu SR, seu SR o senhor lembra o meu nome?

SR Camila.

Ent. Bruna. (risos)

SR Ah Bruna... parece com a Camila... confundi...

Ent. Tudo bem, é... se eu quisesse, se eu dissesse assim, seu RS“o João é muito gordo, o João é tão gordo, meu deus, como ele é gordo, ele é um..." que nome de animal o senhor colocaria aí?

SR Um porco né. (riso)

Ent. Um porco de gordo? (risos) Muito bem, seria a primeira, a primeira coisa que o senhor falaria? 
SR É.

Ent. É? “O João é um porco"?

SR É. De gordo né.

Ent. De gordo, tá certo, muito bem. É... “o João... ai como o João é grosso! Nossa, ele é muito grosso, ele trata as pessoas muito mal. O João é um..."

SR Cavalo.

Ent. Cavalo, muito bem. Agora e se eu disser "o João é muito bonito, o João é lindo, o João é um..."

SR Pão. (risos)

Ent. Pão? Poderia ser, é uma metáfora também, mas eu queria um nome de bicho. "Nossa, como o João é lindo, olha o João, o João é um..."

SR Nossa...

Ent. Menina que fala assim "olha que..."

SR Fugiu viu...

Ent. Fugiu?

SR Vamos pensar se fosse a Maria "Nossa a Maria é muito linda, olha a Maria, ela é uma..."

Ent. Princesa... uma... foi...

Ent. Hum hum, mas nome de bicho o senhor não consegue pensar em um?

SR Tô fazendo, mas não sai do lugar.

Ent. Tchô ver. Não, vou pular esse, depois a gente pergunta de novo, tá bom? É... e se eu dissesse assim, seu SR, “o João é muito forte, o João é muito forte, meu deus do céu o João é um...?

SR O... o cavalo de corrida...

Ent. Um cavalo de corrida de tão forte? 
SR É.

Ent. Bom, eu vou fazer assim, eu tenho aqui, eu tenho algumas palavras aqui que eu tinha pensado que o senhor falaria primeiro, antes de porco, por exemplo, eu achei que o senhor diria outra coisa, e antes de cavalo, pra isso, eu achei que o senhor falaria outra coisa também. Mas depois eu vejo se o senhor diria isso ou não. E se eu dissesse assim "seu SR, a Maria é muito alta, a Maria é muito alta, olha só que menina alta que ela é, ela é uma..."

SR Parece uma girafa né...

Ent. Uma girafa, muito bem. Se eu dissesse assim “ a Maria é muito maldosa, a Maria fala mal dos outrs pelas costas, a Maria é meio falsa... a Maria é uma..."

SR Eu, falei pra você que eu não ia muito bem não...

Ent. Não, o senhor tá indo bem! Todas as respostas que o senhor deu, são foram boas respostas, é só que eu tinha pensado em outra coisa, mas aí... não tá errado, ainda assim.

SR Falsa?

Ent. É. “Essa menina é muito falsa, meu deus, ela é uma...", fofoqueira...

SR Nome de bicho?

Ent. Nome de bicho.

SR Nossa...

Ent. Pode falar qualquer um que o senhor achar que é, não tem problema.

SR Falsa, né?... Uma cachorra, mas...

Ent. Pode ser. (risos)

SR Mas, mas é...é degradante né? Eu não combino com muitos olhos não...

Ent. Chamar as pessoas assim né? 
SR É.

Ent. Mas não tem problema, o senhor pode falar aqui porque eu to só analisando, eu não vou achar que o senhor tá chamando ninguém de cachorra. Muito bem, seu SR, e seu disser assim "o João não é muito inteligente..."

SR Muito burro.

Ent. Ele é um burro, muito bem. Se eu disser "a Maria é muito gorda”?

SR Baleia.

Ent. Muito bem. Se eu disser "o João, ele é muito sujo, ele não toma banho..."...

SR É o porco né.

Ent. É o porco. E seu eu disser “a Maria é muito lenta, ela dirige devagar..."...

SR Uma lesma.

Ent. Uma lesma? (risos) Olha só, deixa eu ver, o senhor respondeu todos...teve alguns que o senhor não disse o que eu esperava, mas também tá certo... só teve um que o senhor não conseguiu que foi o do bonito. "o João é muito bonito, o João é um..."

SR Mas, mas...ó, num ve. Eu...

Ent. É um bicho bem bonitinho, as pessoas geralmente gostam muito, têm em casa...

SR Ah, um gato!

Ent. Um gato. Muito bem. "O João é um gato", era exatamente isso que eu eu queria. Só os que foram diferentes que o senhor falou pra mim...foi de...bom, eu vou fazer essa segunda parte aqui primeiro, depois eu conto pro senhor, o senhor vai perceber também. Seu SR, se eu disser pro senhor "o João é um elefante", que que o senhor entende? 
SR Um olefante?

Ent. É. "Nossa, o João é um elefante..."

SR Bavo não? Muito bavo?

Ent. Muito bravo?

SR Não... não...

Ent. Não... acho... "Nossa, que elefante, meu deus do céu!"

SR Muito grande, não?

Ent. Pode ser, muito grande de muito alto?

SR É... isso... o elefante geralmente é muito alto...

Ent. Hã ham...

SR O...o...indiano fica pequeninho perto dele.

Ent. Hum hum, é verdade... deixa eu dar as opções que eu tenho aqui pro senhor. "Grande" encaixa também, mas vamos ver. O senhor entenderia que o João é gordo, que o João é desleixado, ou que o João é invejoso?

SR Repete tudo...tudo de novo.

Ent. Vou repetir. Se eu disser "nossa, o João é um elefante", o senhor entende que eu to falando que o João é gordo, que o João é desleixado, é largado, ou que o João é invejoso?

SR Não, não...é eu tendi que ele...não é nenhuma dessas coisas, não entendia nenhuma dessas coisas.

Ent. Sério? Se eu dissesse isso pro senhor ia parecer mais que ele é bravo ou que ele é alto?

SR Isso, é.

Ent. Se eu disser pro senhor que o João é um elefante o senhor não entende que ele é gordo? 
SR Não.

Ent. Tá legal.

SR Mas eu, eu a...eu pego a gordura do porco, muito mais gordo, mas pode ser uma baleia, um boi. Mas o boi é... carestiza força né? Faz um pouco fora.

Ent. Então pro senhor ser gordo tá mais ligado a ser porco?

SR É.

Ent. Tá, então tá bom. Segunda pergunta, se eu disser pro senhor "o João é um cavalo", o que que o senhor entende?

SR É mui... Muito bruto, é um... muito forte, o cavalo, ele também é forte, grande...tem que falar pra ele "grande também" eu entendo essas três coisas.

Ent. Hum hum... ele pode ser bruto... ou ele pode ser...como é que o senhor falou? Pode ser forte...

SR Isso, é.

Ent. ... Ou pode ser...grande?

SR Isso, é.

Ent. Tá, entendi, muito bem. E se eu disser "o João é um gato"?

SR É...ela, ele, ela simboliza beleza.

Ent. Beleza.

SR O gato é... agia né? Pra gente, beleza, muito bonito.

Ent. Isso, muito bem. E se eu dissesse "seu SR, o JOão é um touro"?

SR Touro...

Ent. É.

SR Touro... eu entendo por touro a raça e forte. 
Ent. Forte, hum hum, era isso que eu tava pensando, forte, também. E se eu disser "a Maria é muito alta"... ah não, desculpa, essa pergunta eu já fiz, vou pular essa e fazer ela depois então, se eu disser pro senhor... "a Maria é uma cobra"?

SR É muito brava.

Ent. Muito brava?

SR É.

Ent. Hum hum, muito bem. O senhor não entenderia que ela é maldosa?

SR Não.

Ent. Que ela é brava?

SR É.

Ent. Tá, muito bem. Se eu dissesse "o João é um burro"?

SR Entedia que...é... burro...é... como eu falar...é, é... um burro, é...um eu fica surgindo a palavra é, mas é entende que burro é... nossa... mas sei...

Ent. "O João é burro"...

SR É um bo... bobo não, é... bu...

Ent. "Bobo" o senhor disse?

SR É, não... não... Bo... boto, mais ou menos broto...

Ent. É, deixa eu dar aqui umas opções pro senhor: quer dizer que ele é ciumento?

SR Não.

Ent. Quer dizer que ele é gordo?

SR Não.

Ent. Quer dizer que ele é pouco inteligente? 
SR Isso! Isso! (risos)

Ent. (risos) Ah muito bem. Tá certo.

SR Eu, eu, na minha mente, eu falava isso, mas a palavra não vem.

Ent. A palavra... que é "inteligente" não vinha... quer dizer, inteligente, ao contrário, pouco inteligente.

SR É.

Ent. Se eu disser, seu SR, “a Maria é uma baleia”?

SR Eu entendo a gordura.

Ent. Que ela é gorda?

SR É.

Ent. Tá ótimo, perfeito. Se eu disser, “o João é um porco”.

SR Sujo.

Ent. Sujo, hum hum. Antes de pensar que ele é gordo o senhor pensaria que ele é sujo?

SR Isso, também. As duas coisas, porco... o porco sujeira tá...

Ent. Tá ligada ao porco?

SR Isso, isso.

Ent. Tá bom. E se eu disser "a Maria é uma tartaruga"?

SR É, ela é muito devagar. Eu, ela...é... um... bicho perguiça.

Ent. Bicho preguiça? (risos) Boa resposta, são dois animais. Muito bem seu SR, o senhor não foi nada mal não! É bom porque teve umas respostas que eu não tava esperando, que foram diferentes das minhas. 